Paulino Barroso Medina Júnior

\title{
Avaliação dos Impactos da Visitação Pública no rio Formoso, Bonito, MS, Brasil: Subsídios à Gestão Ambiental do Turismo em Áreas Naturais
}

Tese apresentada à Escola de Engenharia de São Carlos, Universidade de São Paulo, como parte dos requisitos para obtenção do título de

Doutor em Ciências da Engenharia Ambiental

Orientador: Prof. Dr. Evaldo L. G. Espíndola

SÃO CARLOS - SP 
AUTORIZO A REPRODUÇÃO E DIVULGAÇÃO TOTAL OU PARCIAL DESTE TRABALHO, POR QUALQUER MEIO CONVENCIONAL OU ELETRÔNICO, PARA FINS DE ESTUDO E PESQUISA, DESDE QUE CITADA A FONTE.

Ficha catalográfica preparada pela Seção de Tratamento da Informação do Serviço de Biblioteca - EESC/USP

Medina Júnior, Paulino Barroso

M491a Avaliação dos impactos da visitação pública no rio Formoso, Bonito, MS, Brasil : subsídios à gestão ambiental do turismo em áreas naturais / Paulino Barroso Medina Júnior; orientador Evaldo L. Gaeta Espíndola. -- São Carlos, 2007.

Tese (Doutorado-Programa de Pós-Graduação em Ciências da Engenharia Ambiental) - Escola de Engenharia de São Carlos da Universidade de São Paulo, 2007.

$\begin{array}{lcccc}\text { 1. } & \begin{array}{c}\text { Ecoturismo. } \\ \text { ambientais. }\end{array} & \text { 4. } & \begin{array}{c}\text { Avaliação } \\ \text { Indicadores }\end{array} & \text { ambiental. } \\ \text { 3. } & \text { Impactos } & \text { 6. Planalto da Bodoquentais. } & \text { I. Título. }\end{array}$

5. Ecossistemas aquáticos 
À minha Pretinha. 


\section{AGRADECIMENTOS}

Descobri o quão árduo e desafiador é fazer Doutorado e ainda manter compromissos relacionados à atuação profissional e conclui que quando contamos com o apoio de outras pessoas (amigos, alunos, colegas, familiares e até desconhecidos), podemos atingir objetivos aparentemente inacessíveis.

Por isso, gostaria de registrar meu especial agradecimento a todos os que contribuíram com minha jornada de doutoramento:

Ao Prof. Evaldo Espíndola, pela amizade, confiança e crédito à minha proposta, mesmo Bonito sendo tão distante de São Carlos;

A minha esposa Silvia, pela compreensão da falta de tempo em função do excesso de compromissos invariavelmente assumidos e pelo seu apoio constante e incondicional - "O anel que tu me destes não é de vidro";

Ao Valdir Specian, à Viviane e ao pequeno Renan, por me acolherem em seu lar, em São Carlos, no período em que cumpri os créditos das disciplinas de doutorado;

Aos professores do Programa de Pós Graduação em Ciências da Engenharia Ambiental/EESC/USP, por contribuírem com minha formação profissional;

Ao amigo Fabio Roque, pelas nossas "viagens" sobre conservação de invertebrados e ecossistemas aquáticos, pela imensa paciência com as análises estatísticas dos resultados do trabalho e, principalmente, pela amizade;

Aos alunos, ex-alunos e amigos (Ana Paula, Cleberson, Danieli, Eleri, Fábio Punk, Fábio Vinícius, Heloisa, Juliane, Lara, Sandra, Thiagão, Verônica, Vanderlice, Walteir, Ricardo e Silvia) que contribuíram com a coleta de dados físicos, biológicos e sócio-econômicos em campo ou com a obtenção de informações adicionais junto às instituições oficiais;

Aos amigos Walteir Roberto de Souza (Quati) e Domingos Sávio, pelo apoio concedido para a triagem e identificação dos macroinvertebrados bentônicos; 
Ao Silvio Jacks, pelo apoio na confecção do mapa da área de estudo;

Ao João Siloé, pela ajuda na formatação final da tese e pela amizade fraterna;

Ao Serjão de Bonito e Família, por nos acolher em sua aconchegante casa durante as campanhas de campo;

À Márcia Brambilla, por nos emprestar seu "lar bonitense" em muitas de nossas idas a Bonito;

Ao Programa de Pós Graduação em Ciências da Engenharia Ambiental e ao Laboratório de Biodiversidade e Conservação de Ecossistemas Aquáticos da UNIDERP, pelo apoio estrutural dispensado à execução do trabalho;

À Fundação Manoel de Barros, pelo apoio financeiro aos projetos de pesquisas desenvolvidos no Planalto da Bodoquena;

Aos proprietários e/ou gestores dos empreendimentos que foram estudados, pela receptividade e apoio logístico;

À Fundação Neotrópica, pela disponibilização de dados e mapas sobre o rio Formoso e os empreendimentos de turismo nele instalados;

Á minha família, por existir;

Aos que possivelmente não foram citados, minhas sinceras desculpas. O tempo está se esgotando e minha memória insiste em não colaborar. Minha gratidão a todos. 


\section{RESUMO}

Visando compreender os impactos da visitação pública sobre ecossistemas aquáticos continentais, desenvolveu-se o presente estudo no rio Formoso, Planalto da Bodoquena, Mato Grosso do Sul, Brasil. Através de um estudo de caso, buscou-se caracterizar os impactos provocados pelas diferentes modalidades de uso público no rio Formoso, considerando o emprego de variáveis físicas e biológicas como indicadoras do impacto da visitação pública em um período de alta temporada, carnaval de 2006. Complementarmente, para melhor compreender a relação entre os impactos impressos no ambiente e o uso predominante na região, foram caracterizados aspectos da relação dos empreendimentos turísticos com os ecossistemas aquáticos no Planalto da Bodoquena, a estrutura dos empreendimentos turísticos abertos ao uso público ao longo do rio Formoso e o perfil e aspectos da percepção ambiental dos visitantes desses empreendimentos. Os dados foram obtidos a partir de pesquisa documental, aplicação de questionários aos visitantes do rio Formoso e coleta em campo de dados relativos às variáveis físicas e biológicas descritoras dos diferentes compartimentos do ecossistema aquático. Os seguintes resultados ficaram evidenciados: 1 . Os ambientes aquáticos são os atrativos naturais mais demandados pelos empreendimentos de turismo e visitantes; 2 . os balneários exibem os maiores níveis de impacto em todos os compartimentos do ecossistema aquático analisado; 3. a movimentação da água e o pisoteio do fundo são as interferências da visitação pública mais pronunciadas sobre o rio Formoso; 4. as áreas mais impactadas são aquelas que recebem os visitantes com menos exigência ambiental; 5. as variáveis transparência da água, folhedo, riqueza e diversidade taxonômica de macroinvertebrados bentônicos e o Índice de Alteração da Estrutura Física de Ecossistemas foram selecionadas como os indicadores mais aplicáveis à avaliação e ao monitoramento dos impactos da visitação pública no rio Formoso.

PALAVRAS-CHAVE: ecoturismo, avaliação ambiental, impactos ambientais, indicadores ambientais, ecossistemas aquáticos, Planalto da Bodoquena. 


\section{ABSTRACT}

With the aim of understanding the impacts of visits by the public on inland aquatic ecosystems, the present study was developed at the Formoso River, Bodoquena Plateau, Mato Grosso do Sul, Brazil. Through a case study, it was attempted to characterize the impacts provoked by different modes of public use of the Formoso River, considering the use of physical and chemical variables as indicators of public visitation impacts during the high season, Carnaval of 2006. In conjunction, to better understand the relationships between the impacts on the environment and the predominant use of the region, aspects of the relationship between tourist undertakings and the aquatic ecosystems of the Bodoquena Plateau, the structure of the tourist undertakings open to the public along the river, and the profile and aspects of environmental perception of the visitors to these tourist undertakings were characterized. The data were obtained from research of documents, use of questionnaires filled-out by visitors to the river, and collection in the field of physical and biological variables describing different compartments of the aquatic ecosystem. The following results were obtained: 1 . The aquatic environments are the most sought-after by the tourist undertakings and visitors; 2 . the bathing areas exhibit the highest levels of impact of all the compartments analyzed of the aquatic ecosystem; 3 . water movement and trampling of the bottom substrate are the most pronounced interferences of public visitation in the river; 4. the most impacted areas receive the least environmentally demanding visitors; 5. the variables water transparency, leaf litter, richness and diversity of benthic macroinvertebrates, and the Index of Ecosystem Physical Structure Alteration were selected as the most applicable indicators of environmental evaluation and monitoring of public visitation impacts on the Formoso River.

KEY-WORDS: Ecotourism, environmental impacts, environmental indicators, aquatic ecosystems, Bodoquena Plateau. 


\section{ìNDICE}

Resumo $\quad$ i

Abstract ii

1. Introdução Geral 1

1.1. Ecoturismo ou turismo de natureza? 3

1.2. Impactos da visitação pública em áreas naturais 5

1.3. Impactos da visitação pública em ecossistemas aquáticos

1.4. Limite Aceitável de Mudança 13

1.5. A aplicabilidade de bioindicadores no monitoramento de ecossistemas 16 aquáticos

2. Material e métodos 19

2.1. Área de estudo 19

2.2 Pesquisa documental $\quad 24$

2.3. Coleta de dados em campo e procedimentos de obtenção dos descritores 26 das variáveis

2.3.1. Descrição estrutural e funcional das estações de amostragem 27

2.3.2. Descritores da visita e dos visitantes 28

2.3.2.1. Amostragem 30

2.3.3. Indicadores de impacto da visitação pública 31

2.3.3.1. Alterações na estrutura física do ecossistemas 32

2.3.3.2. Indicadores das condições da água e do sedimento 35

2.3.3.2.1. Variáveis descritoras das condições da água 36

2.3.3.2.2. Variáveis descritoras das condições do sedimento 37

2.3.3.3. Macroinvertebrados bentônicos 38

2.4. Tabulação e análise dos dados

2.4.1. Características dos empreendimentos, da visita e dos visitantes 39

2.4.2. Indicadores de impactos da visitação 40

3. Atividade turística no Planalto da Bodoquena: demanda por ecossistemas aquáticos, adequação ao processo de licenciamento ambiental e caracterização da estrutura para visitação e dos usos no rio Formoso

3.1. Demanda da atividade turística por ecossistemas aquáticos no Planalto da Bodoquena

3.2. Adequação das atividades turísticas ao processo de licenciamento ambiental no Planalto da Bodoquena

3.3. Caracterização da estrutura para visitação e dos usos no rio Formoso 55

4. Caracterização da visita e dos visitantes dos empreendimentos de turismo ao 58 longo do rio Formoso

4.1. Caracterização geral ao longo do rio Formoso 
4.2. Características da visita, características e percepção ambiental dos visitantes e sua relação com os empreendimentos estudados

5. Caracterização dos impactos ambientais do uso público no rio Formoso através do emprego de variáveis físicas e biológicas físicas e biológicas

5.1. Condições abióticas da água e do sedimento

5.2. Macroinvertebrados bentônicos

5.3. Estrutura física do ecossistema

5.4. Seleção de indicadores

6. Conclusões e recomendações

7. Referências bibliográficas

96

Anexos

Apêndice 


\section{Introdução Geral}

As relações do Homem com a natureza são tão antigas quanto a própria existência da humanidade. As características dessas relações, entretanto, têm se alterado significativamente com o passar do tempo, condicionadas pelo processo de transformação a que o Homem sempre esteve sujeito.

O processo civilizatório introduziu conceitos de maior rendimento com a implantação de atividades altamente modificadoras do ambiente, culminando com o processo de urbanização, resultando em externalidades que afetam profundamente o equilíbrio da biosfera. Assim, as formas de uso da terra têm ultrapassado os limites ecológicos, reduzindo os estoques dos recursos não renováveis e a capacidade de renovação daqueles renováveis, poluindo a água, a atmosfera e o solo (CORSON, 1996).

O modelo dominante de desenvolvimento construído no período moderno, calcado no sistema industrial capitalista, depende de recursos naturais numa dimensão desconhecida a qualquer outro sistema social na história da humanidade, levando à destruição da natureza (ALTVATER, 1995), colocando em risco a própria sobrevivência da espécie humana. O limite ambiental é afetado pelo crescimento acelerado da transformação de bens da natureza para satisfazer as necessidades humanas nem sempre básicas para a sobrevivência pessoal.

A dependência do sistema produtivo em relação ao ambiente natural e a descoberta dos limites da natureza em relação à sua transformação geraram a chamada crise ambiental (MORETTI, 1996). De fato, os modelos de desenvolvimento vigentes refletem os paradigmas de percepção, pensamento e ação que têm conduzido a humanidade à situação atual, de forma que somente mudanças profundas nesses paradigmas permitirão a manutenção do equilíbrio no planeta dentro de um modelo de desenvolvimento ecologicamente sustentável (ALMEIDA-JUNIOR, 1997).

A reflexão sobre a presente situação e o conseqüente custo ambiental do modelo de desenvolvimento econômico imposto levou a sociedade a perceber a necessidade de se repensar tal modelo. Na busca pela solução da crise ambiental é crescente a cobrança 
da sociedade por uma adequação das atividades econômicas às necessidades de conservação ambiental. Nesse contexto, o turismo se destaca como uma atividade capaz de promover o crescimento econômico dentro das premissas da sustentabilidade ambiental, permitindo a compatibilização do uso com a consenvação dos recursos naturais (CEBALLOS-LASCURÁIN, 1995).

Na década de 1980, profissionais do turismo motivados pelas implicações do relatório Nosso Futuro Comum em suas atividades, passaram a difundir a importância do desenvolvimento do turismo dentro de preceitos da sustentabilidade ambiental, o qual deveria estar atrelado ao compromisso de não permitir que suas atividades colocassem em risco os recursos naturais (SWARBROOKE, 2000).

Uma das primeiras estratégias de ação voltada à sustentabilidade do turismo nasceu na Conferência Global, realizada no Canadá em 1990, onde representantes de diferentes setores ligados ao turismo discutiram a importância do ambiente equilibrado na sustentação da atividade, destacando os reflexos ambientais negativos dos projetos turísticos mal planejados (FENNELL, 2002).

A partir desse marco, o turismo de massa e o turismo alternativo passam a ser colocados como dois grandes segmentos divergentes dentro do contexto da sustentabilidade do turismo, sendo o último, como o próprio nome diz, apresentado como única alternativa capaz de promover a sustentabilidade da atividade. Todavia, Fennell (op. cit.) chama atenção para o fato de que, dependendo da forma como essas modalidades são desenvolvidas, tanto o turismo de massa pode incluir práticas sustentáveis, como o turismo alternativo pode avançar as fronteiras da sustentabilidade. Por outro lado o autor reconhece que, ao menos em teoria, a maioria das formas de turismo alternativo, que inclui o turismo sóciocultural e o ecoturismo, são sustentáveis na natureza.

Estudiosos da área de turismo destacam a incontestável inter-relação entre essa atividade e o ambiente, onde o ambiente se constitui em matéria prima do turismo, especialmente quando este está baseado em atrativos naturais (RUSCHMANN, 1999; 
CEBALLOS-LASCURÁIN, 1995), chegando a propor que para a sustentabilidade do turismo o atrativo deva ser assumido como o principal capital, sob o risco de inviabilizar o negócio se for destruído (MARTINS, 1999).

\subsection{Ecoturismo ou turismo de natureza?}

Há uma reconhecida falta de consenso em torno da definição do termo ecoturismo, que se confunde com a própria esfera do turismo alternativo e já recebeu denominação de turismo brando, verde, ecológico, ambiental e outras variações do termo. O termo predominante hoje é o ecoturismo, que teoricamente define um tipo de turismo com menos orientação sociocultural e mais dependente da natureza e dos recursos naturais como os principais componentes ou motivadores da atividade, a qual deve estar vinculada a um alto envolvimento dos seus praticantes com o conhecimento e a proteção do destino (SERRANO, 2001; FENNELL, 2002).

Em meio à ambigüidade que envolve o termo, a Embratur, através das Diretrizes para uma Política Nacional de Ecoturismo, definiu o ecoturismo como sendo um segmento da atividade turística que utiliza, de forma sustentável, o patrimônio natural e cultural, incentiva sua conservação e busca a formação de uma consciência ambientalista, promovendo o bem estar das populações envolvidas (EMBRATUR, 1994).

Alguns autores divergem sobre a origem do termo ecoturismo, mas dados de literatura indicam que Ceballos- Lascuráin foi o primeiro a utilizá-lo no início da década de 1980 (BOO, 1990; THOMPSON, 1995; FENNELL, 2002).

Todavia há evidências de que a recreação ao ar livre e o contato com a natureza já eram desenvolvidos em diferentes partes do mundo há muito mais tempo (WILSON, 1992; FENNELL, 1998; SERRANO, op. cit.). Esse conjunto de experiências pode ser genericamente chamado de turismo com base na natureza ou simplesmente turismo de natureza (MCKERCHER, 2002).

O turismo de natureza, por sua vez, engloba uma série de modalidades de turismo baseados em atividades ao ar livre e em contato com ambientes naturais, incluindo o 
ecoturismo, turismo de aventura e outros (MCKERCHER, 2002; LITVIN, 1996). Trata-se, portanto, de um termo abrangente que envolve muitas atividades erroneamente rotuladas de ecoturismo para dar uma conotação de "ambientalmente responsável" às atividades. O turismo de natureza não implica, necessariamente, que as atividades são fundamentadas em modelos de uso preocupados com a sustentabilidade ambiental e a minimização dos impactos negativos nos destinos visitados, conforme destacado por Goodwin (1998).

De acordo com Ceballos-Lascuráin (1996), essa modalidade de turismo tem suas raízes nos novos paradigmas criados no final da década de 1960, a partir das constatações dos problemas ambientais e da necessidade de conservação ambiental. Pires (1998) também partilha dessa opinião e sugere que o turismo de natureza teve sua origem atrelada à própria origem do ambientalismo e do excursionismo.

No Brasil, os registros de atividades relacionadas ao turismo com base na natureza são reconhecidos em documentos da década de 1960 e até do inicio do século XX (SERRANO \& LUCHIARE, 1993; PIRES, 1998).

A origem e o desenvolvimento do turismo de natureza refletem o empenho dos naturalistas e a desvalorização da vida urbana decorrentes da queda na qualidade ambiental, expressando o desejo de ruptura com o cotidiano e provocando uma crescente busca por lugares quase intocados, ao mesmo tempo em que se diferencia do convencional pela valorização das áreas não transformadas (DIEGUES, 1996; SERRANO, 2001).

De acordo com a organização mundial de turismo, o número de turistas no mundo saltou de 25 milhões para 698 milhões entre os anos de 1950 e 2000, se posicionando com destaque na economia mundial. Ainda de acordo com esta organização, a tendência é de que esse número seja de 1 bilhão em 2010 e supere os 1,5 bilhões até 2020 (WORD TOURISM ORGANIZATION, 2003). Boa parte desse público está voltada para o turismo de natureza, que na década passada já representava $10 \%$ do turismo mundial, com crescimento de $20 \%$ ao ano (SANTANA, 1998). No Brasil, os negócios com turismo 
em áreas naturais tiveram um crescimento de 33\% entre 1994 e 1995 (BRASIL, 2001). Na Bacia do Alto Paraguai, o turismo de natureza passou a se desenvolver na década de 1970, passando a desempenhar importante papel nas relações de capital (GARMES, 1997).

Um ponto importante a destacar é o de que o turismo com base na natureza (ou simplesmente turismo de natureza) refere-se muito mais ao destino onde está baseada a atividade do que a um conceito ou a uma modalidade de turismo. Pode incluir, portanto, modalidades de turismo que apresentam diferentes tipos de relação com o meio natural e, consequentemente, que imprimem diferentes níveis de impactos ambientais. Não representa, necessariamente, turismo de mínimo impacto.

Por se tratar de um termo mais genérico e isento de rótulos, em nosso texto utilizaremos turismo de natureza para designar as viagens a áreas naturais. Para evitar o emprego errôneo e indiscriminado do termo ecoturismo, este será, quando conveniente, permutado por turismo de natureza.

Já para designarmos especificamente a utilização de áreas naturais para fins de recreação pelo público de diferentes procedências, julgamos mais conveniente o emprego dos termos "visitação pública" ou "uso público". Esses termos são mais adequados por que áreas naturais recebem uma série de outros visitantes além de turistas, incluindo escolas, população local, comerciantes, entre outros (GIONGO et al, 1999). Assim, os termos turistas e visitantes, turismo e visitação pública/uso público serão empregados de maneira permutável no presente trabalho.

\subsection{Impactos da visitação pública em áreas naturais}

Assim como outras atividades econômicas, o turismo também é considerado um agente de mudanças, cuja expansão descontrolada pode projetá-lo além de limites socioeconômicos e ecológicos sustentáveis. Apesar das afirmações de que se trata de uma forma de desenvolvimento que representa um meio prático e eficaz de crescimento 
sustentável, em muitos casos esta atividade tem provocado uma série de impactos ambientais de diferentes ordens (BRANDON, 1995).

Os primeiros trabalhos tratando do impacto do turismo sobre os destinos, se concentraram principalmente nos aspectos econômicos, o que esteve relacionado à sua fácil quantificação bem como a tendência de demonstrar o benefício econômico da atividade (ARCHER \& COOPER, 2001). Para esses autores qualquer discussão relacionada aos impactos do turismo deve incluir noções de capacidade de carga e de critérios para avaliação dos impactos, uma vez que essa atividade tende a se voltar para ambientes singulares e frágeis, favorecendo a neutralização dos benefícios econômicos por conta dos impactos sócio-ambientais.

No Brasil, por exemplo, o turismo ainda tem acontecido de forma desordenada e impulsionado, basicamente, pela oportunidade mercadológica, ignorando-se os benefícios socioeconômicos e ambientais esperados e, na maioria das vezes, comprometendo o conceito e a imagem do produto brasileiro nos mercados internos e externos (BRASIL, 1994). Essa situação torna-se ainda mais grave ao se constatar que os impactos ambientais não têm sido estudados de forma sistemática, existindo carência de informações a respeito no país (RUSCHMANN, 1999).

É universalmente reconhecida a importância do ambiente natural conservado para o turismo baseado na natureza, para o qual deve ser considerado ponto essencial no processo de desenvolvimento e gerenciamento (MOLINA, 2000; WEARING \& NEIL, 2001; FENNELL, 2002). Todavia, de acordo com esses autores, o desenvolvimento rápido e descontrolado da visitação em localidades com recursos naturais de excepcional beleza e importância, muitas vezes ímpares, provoca excesso de demanda e superdimensionamento da oferta, que altera a paisagem fazendo a destinação turística perder as características que deram origem à atividade.

Assim, se o turismo de natureza crescer a uma escala de massa, tenderá a adquirir características de turismo de massa, deixando de ser um caminho para a 
sustentabilidade e se transformando em ameaças às áreas visitadas (SWARBROOKE, 2000).

Por representarem, na maioria das vezes, ecossistemas frágeis e atraírem cada vez mais visitantes, as áreas naturais têm sido progressivamente afetadas pelo uso público. O monitoramento e manejo dessas áreas se tornam, portanto, imprescindíveis na busca de estratégias de desenvolvimento do uso recreativo em consonância com conservação da natureza (FREIXÊDAS-VIEIRA et al., 2000).

De acordo com Cole (1996), conciliar o uso recreacional com a conservação dos recursos naturais continua sendo um dos mais urgentes desafios do manejo de áreas naturais. Nesse sentido, Sandevile-Jr (2002) destaca que a delimitação de impactos aceitáveis, decorrentes do uso público em áreas naturais, só é possível a partir da compreensão dos processos biofísicos e culturais da natureza, mediante o suporte da análise cientifica à utilização dos recursos naturais.

Buscando respostas para as questões envolvendo os impactos ambientais do uso público em áreas naturais, estudos começaram a ser desenvolvidos já na década de 1950, nos EUA (COLE, 1993 apud TAKAHASHI, 1998). Provavelmente motivado pela tendência atual, tanto mundial quanto brasileira, de criação de unidades de conservação para proteção da natureza (IUCN, 1984; BRASIL, 1999; DOUROJEANI \& PÁDUA, 2001; SNUC, 2002), a grande maioria dos estudos referentes à avaliação e manejo dos impactos ambientais do uso público em áreas naturais está concentrada nessas áreas especialmente protegidas (CEBALLOS-LASCURÁIN, 1996; SERRANO, 1997; MAGRO, 1999; ROBIM, 1999; TAKAHASHI, 1998; WEARING \& NEIL, 2001; WALLACE, 2002).

No Planalto da Bodoquena, Mato Grosso do Sul, um dos maiores pólos turísticos do Brasil (EMBRATUR, 1999), a visitação pública a áreas naturais é realizada basicamente em propriedades particulares, onde os estudos sobre os impactos ambientais da atividade são ainda incipientes.

\subsection{Impactos da visitação pública em ecossistemas aquáticos}


Uma pesquisa realizada pela EMBRATUR demonstrou que os recursos hídricos têm forte apelo turístico, fazendo parte da preferência dos visitantes em todas as regiões pesquisadas (EMBRATUR, 1998). Os rios, quedas d'água e lagos (naturais ou artificiais) são os sistemas mais procurados pelos turistas na grande maioria das regiões.

Conseqüentemente, os ecossistemas aquáticos continentais concentram a maior parte dos impactos ambientais provenientes das atividades turísticas. Investigações promovidas por organismos nacionais e internacionais envolvidos com a questão demonstram um alto grau de contaminação em águas utilizadas por banhistas em diferentes países, sendo verificada, inclusive a perda de flora e fauna aquáticas em lagos e lagunas de países latino americanos (MOLINA, 1998). Isso reforça a necessidade de se estabelecer políticas locais para a conservação desses ecossistemas.

Todavia, os efeitos e as causas dos impactos em ecossistemas aquáticos associados à visitação pública são poucos conhecidos. Estudos relacionados ao uso público de áreas naturais estão voltados quase que exclusivamente para os ecossistemas terrestres, enfocando principalmente aspectos do solo e da vegetação (LIDDLE, 1988; COLE, 1991; COLE \& BAYFIELD, 1993; SPANDAU, 1994; COLE, 1995; TAKAHASHI, 1998; MAGRO, 1999). No Brasil, essa situação é ainda mais evidente.

Conforme constatação feita por Kuss et al. (1990), a ausência de estudos referentes aos impactos da recreação sobre os recursos hídricos se dá basicamente pelo fato de que as mudanças ocasionadas pela visitação publica na água não chamam tanta atenção e nem são tão óbvias quanto aquelas observadas nos ecossistemas terrestres. A carência de métodos reconhecidamente aplicáveis ao desenvolvimento de estudos científicos envolvendo o uso público de ambientes aquáticos também se constitui em um importante limitador na produção de informações científicas sobre o tema.

De maneira geral, os poucos estudos realizados estão focados na proteção ao visitante e se concentram em analisar a extensão da contaminação fecal em áreas naturais, a partir de análise de Coliformes Fecais, o que não fornece respostas satisfatórias (SILVERMAN \& ERMAN, 1979). 
Por outro lado, mesmo em lagos e rios em que a contaminação fecal é ausente, outros tipos de impactos têm sido registrados, ainda que de forma bastante incipiente. Isso pode ser um indicativo da ineficiência do emprego exclusivamente de Coliforme Fecais para se medir os impactos da visitação pública em ecossistemas aquáticos, como tem predominantemente ocorrido (DIKMAN \& DORAIS, 1977; GARY, 1982;).

O efeito sobre o estado trófico dos ecossistemas aquáticos, provocado pela entrada de nutrientes associados a sólidos suspensos provenientes do entorno em função da atividade turística, já foi registrado por alguns autores (DIKMAN \& DORAIS, op. cit; GARY, op. cit.). Em um lago localizado em uma área silvestre do Canadá, por exemplo, Dikman \& Dorais (op cit.) verificaram alta concentração de fósforo e aumento na densidade do fitoplâncton, o que foi atribuído ao aumento da erosão de substrato rico em fósforo desencadeado pela implantação de trilhas terrestres nas adjacências. Por outro lado, a redução de outros íons também é atribuída ao uso público, como verificado por Taylor \& Erman (1979), que ao estudarem lagos intensamente visitados verificaram uma menor concentração de ferro.

Para Hammit e Cole (1998), em lagos oligotróficos os impactos relacionados à entrada de nutrientes e provocados pela visitação pública no entorno tendem a ser ainda mais acentuados. Os mesmos autores verificaram que o uso de embarcações e outros equipamentos de flutuação, muito comum em atividades de recreação, exercem importantes efeitos sobre o ambiente aquático, contribuindo para a turbidez da água, poluição por dejetos humanos e contaminação aquática por despejos de gasolina e lubrificantes.

O despejo de combustíveis e lubrificantes no ambiente aquático, por sua vez, pode interferir nas propriedades físicas, químicas e biológicas da água através da liberação de seus produtos constituintes (MURATORI, 1960 apud HAMMIT \& COLE, 1998). O autor ressalta que esses produtos promovem, dentre outros, a redução na concentração de oxigênio no meio aquático ao formar uma barreira física na superfície da água, impedindo a difusão de gases na interface água-ar. Os organismos também são 
diretamente afetados ao serem impregnados com esses produtos, o que acaba interferindo na produtividade do sistema e na estrutura das comunidades aquáticas.

É evidente que todo tipo de interferência nos ecossistemas aquáticos direciona impactos para os organismos aí presentes. Todavia, no caso de uso público esses impactos não têm sido satisfatoriamente documentados. De acordo com Hammit e Cole (op cit.), os poucos estudos realizados nesse sentido tratam, principalmente, da ictiofauna, em especial no que diz respeito ao excesso de pesca e à introdução de espécies exóticas. Para esses autores, o uso de veículos of-rood e embarcações afetam indiretamente essa comunidade ao facilitar o acesso a ambientes aquáticos remotos. Isso acaba promovendo a pesca e a conseqüente alteração na comunidade de peixes em um número cada vez mais crescente de ecossistemas.

Alterações na fauna de insetos aquáticos, moluscos e anelídeos também já foram atribuídas ao uso público, conforme estudos realizados por Taylor \& Erman (1980), em lagos utilizados para visitação pública. Efeitos da visitação sobre a vegetação aquática foram documentadas por Taylor \& Erman (1979), que registraram maior biomassa de macrófitas em lagos intensamente visitados quando comparados a outros sistemas.

A partir da escassa literatura que trata do assunto, verifica-se que os impactos da recreação sobre os ecossistemas aquáticos podem ser atribuídos a diferentes atividades (GARY, 1982; HAMMIT \& COLE, op. cit.; WORLD TOURISM ORGANIZATION, 1998; MAGRO 2001) e, dependendo da atividade geradora, esses impactos poderiam ser classificados em autóctones ou alóctones:

1. Impactos autóctones: aqueles provocados por atividades desenvolvidas no próprio ambiente aquático:

1.1. Pesca esportiva e amadora: promovem a poluição da água por resíduos sólidos e introdução de espécies exóticas;

1.2. Banhos de cachoeira e natação: induzem à abertura de trilhas que podem levar a erosão de margens e assoreamento de canais, promovem 
ressuspensão de sedimento e turvamento da água bem como a perturbação de organismos aquáticos;

1.3. Esportes náuticos (raffting, cannyoing, bóia-cross, e outros): provocam contaminação da água por resíduos sólidos, ressuspensão de sedimentos, alterações morfológicas dos ambientes visitados (margem e fundo) e alterações na biota através de impactos diretos e indiretos (alteração de habitat e áreas de reprodução, intoxicação por resíduos e remoção de fontes de alimentos);

1.4. Passeios de barcos motorizados e similares: promovem alterações morfológicas (nas margens através da construção de acessos e no leito pela navegação intensiva e com equipamentos inapropriados), contaminação da água por óleos e lubrificantes e alterações na biota através de impactos diretos e indiretos.

2. Impactos alóctones: aqueles provocados por atividades desenvolvidas nas adjacências dos ecossistemas aquáticos:

2.1. Acampamentos e trilhas: provocam o carreamento de sólidos e nutrientes aos ambientes aquáticos, podendo ocasionar assoreamento, redução na transparência da água e desencadear processos de eutrofização. Quando desenvolvidas em áreas marginais podem provocar erosões e descaracterização geomorfológica dos sistemas pela retirada da vegetação ribeirinha. A realização de fogueiras e a improvisação de fogareiros e churrasqueiras em área de acampamentos próximos a ambientes aquáticos facilita a chegada, nestes, de cinzas e outros resíduos, geralmente ricos em nutrientes;

2.2. Passagem de veículos of-road: descaracterização das margens e alterações morfológicas pela remoção de bancos de sedimentos e ressuspensão de materiais sedimentáveis, provocando turvamento da água e aumento na concentração de nutrientes na coluna d'água. Essa atividade pode provocar efeitos diretos e indiretos nos organismos, afetando a estrutura das comunidades aquáticas. 
Para Hammit \& Cole (1998), a redução no uso tende a reduzir os impactos sobre os ambientes aquáticos, mas, em geral, a quantidade de uso é menos importante que a localização do uso e o comportamento do visitante.

No Brasil, a situação dos estudos envolvendo impactos da visitação pública em ecossistemas aquáticos continentais não difere das outras partes do mundo, sendo estes bastante raros. Os poucos trabalhos realizados dão ênfase às características físicas e químicas da água (MAGRO et al., 2001; DOMINGOS, 2002).

Estudos realizados no rio Betari (SP) demonstraram que a variação das características limnológicas do sistema esteve mais associada às variações ambientais sazonais e de caráter geomorfológico do que às atividades turísticas desenvolvidas no ambiente (DOMINGOS, op. cit.). Situação semelhante também foi registrada na região da Serra do Mar (SP), onde a estratégia de amostragem e as variáveis empregadas permitiram pouca ou nenhuma associação dos impactos verificados com a visitação pública, o que levou os autores a proporem a implementação de programas contínuos de monitoramento dos ambientes aquáticos, bem como a inserção de outras variáveis químicas e biológicas (MAGRO et al., 2001).

O monitoramento do rio Baia Bonita, em Bonito (MS), desenvolvido por Sabino \& Andrade (2002), se destaca por incluir, além de variáveis físicas e químicas, o emprego de organismos aquáticos na avaliação dos impactos da visitação pública naquele ecossistema. Nesse trabalho, os autores destacaram a presença de organismos-chave (topo de cadeia), o comportamento de espécies residentes e a estrutura da comunidade íctica como indicadores da manutenção das condições ambientais dentro de limites.

Entretanto, ao final de um ciclo de monitoramento, esses mesmos autores apresentam evidências de impactos nas comunidades aquáticas em função do aumento na visitação pública no ambiente estudado (SABINO \& ANDRADE, 2003). No presente trabalho, os autores atribuem o desaparecimento, redução da abundância de indivíduos e diminuição do sucesso reprodutivo de populações de peixes - cascudo (Farlowella spp), 
dourado (Salminus maxillosus) e joaninha (Crenicichla lepidota), respectivamente - à pressão da visitação pública no rio Baia Bonita.

Estudo realizado por Sabino, Medina-Jr \& Andrade (2005) no Balneário Municipal de Bonito, localizado às margens do rio Formoso, também evidenciou a aplicação da piraputanga (Bricon hilarii), peixe símbolo na região, como potencial indicador biológico dos impactos ambientais da visitação pública em ecossistemas aquáticos naturais da região. Os autores verificaram que o comportamento inadequado dos visitantes está provocando alterações no equilíbrio da população de piraputangas do local. Ao receberem alimento artificial dos visitantes, os peixes alteram sua dieta e comportamento alimentar, o que tem provocado obesidade nos organismos e redução em sua atividade de forrageamento a fontes naturais de alimentos, importante função ecológica desempenhada pela espécie no ecossistema.

Um trabalho desenvolvido por Bervian, Medina-jr \& Roque (2006) pode ser considerado de vanguarda por aplicar abordagem experimental para avaliar os impactos da visitação pública em ecossistemas aquáticos continentais em regiões tropicais. Através de simulações experimentais realizadas em um trecho do rio Formoso (Planalto da Bodoquena, Mato Grosso do Sul), os autores concluíram que o pisoteio e a movimentação dos visitantes promovem desestruturação física e biológica nos ambientes visitados, aumentando a deriva de macroinvertebrados bentônicos e matéria orgânica particulada.

\subsection{Limite aceitável de mudança em áreas naturais}

Tendo em vista que a vulnerabilidade de um atrativo ou local turístico depende da fragilidade dos ecossistemas que compõem o meio, para preservar sua integridade é preciso delimitar a capacidade dos ambientes em suportar a pressão do uso público.

$\mathrm{Na}$ tentativa de se evidenciar os limites da capacidade ambiental perante o uso público foi desenvolvida uma série de modelos, os quais foram testados basicamente em ambientes terrestres (WAGAR, 1964; CLARK \& STANKEY, 1979; STANKEY et al., 1985). 
Esses modelos, que já sofreram importante processo de evolução e ajustes, poderiam perfeitamente ser aplicados ao monitoramento e manejo de ecossistemas aquáticos.

O primeiro modelo desenvolvido foi o conceito de Capacidade de Carga (WAGAR, op. cit.). De acordo com o autor, este conceito foi emprestado do manejo de pastagens e adaptado para buscar um número ideal de visitantes. O próprio autor reconheceu mais tarde que, da maneira como proposto originalmente, tratava-se de uma escolha inadequada por considerar a freqüência de visitas e número de visitantes como fatores chaves para identificar o nível de exploração suportado pelos recursos naturais. Alguns ajustes foram acrescentados por outros autores, mas a manutenção do termo manteve também a idéia de que se tratava ainda da proposta original. Além disso, as novas propostas continuaram dando especial ênfase à capacidade de carga física (CIFUENTES, 1992).

Para Wallace (1995) não há uma correlação direta entre o número de visitantes e os impactos provocados. Visando adequar este conceito, deslocando a atenção do tipo e grau de uso que uma área recebe para os atributos biofísicos, sociais e administrativos, surgiu o modelo ROS - Recreational Opportunity Spectrum, apresentado por Clark \& Stankey (1979). Este modelo envolve a combinação de condições físicas, biológicas, sociais e administrativas que dão valor a um local, estando fundamentado na capacidade de carga recreativa.

O grau de impacto depende de uma série de variáveis que se somam à quantidade de visitação, com especial destaque para o comportamento dos visitantes, representado principalmente pelo grau de consumo e conforto demandados (WALLACE, 2002). Para esse autor, o método LAC - Limits of Acceptable Change, proposto por Stankey et al. (1985), seria o mais adequado para monitorar os limites de impactos decorrentes da visitação pública em áreas naturais. A metodologia LAC evidencia a evolução das metodologias aplicadas ao manejo do uso público em áreas naturais desde o conceito de capacidade de carga, reconhecendo as dimensões sociais e ecológicas (físicas e biológicas) dos impactos da atividade recreativa. O LAC incorpora o modelo 
ROS, adicionando estratégias para se determinar quais condições ambientais e sociais são aceitáveis, além de propor ações de manejo para se atingir ou manter essas condições.

Uma vez definidos os indicadores sociais e ecológicos adequados, o processo LAC é capaz de responder racionalmente à existência ou não de excesso de visitação, pois permite descrever com objetividade quando uma determinada área destinada a um determinado objetivo está sofrendo impacto (WALLACE, 2002). Para o autor, a capacidade e os limites não são estáticos e variam de acordo com as mudanças que ocorrem nas expectativas e preferências do visitante.

Sabendo-se que não há correlação direta entre o número de visitantes e os impactos negativos sobre os recursos naturais e a experiência dos visitantes, o conceito de capacidade de carga tem evoluído para modelos mais completos que buscam medir o que realmente está ocorrendo com os recursos da área visitada e a experiência do visitante. Assim, o grau de impacto passou a ser reconhecido como dependente de muitas variáveis que se somam à quantidade de visitação, incluindo o grau de consolidação de estrutura local, os fatores de motivação e o comportamento dos visitantes, o tamanho do grupo e as características das variáveis ambientais (STANKEY et al., op. cit.; MCCOOL, 1996; TAKAHASHI; 1998; WALLACE, 2002).

Analisando as diferentes metodologias propostas, verifica-se que os modelos mais recentes apresentam ferramentas aplicáveis ao estabelecimento de limites da capacidade ambiental frente à atividade turística, o que vai depender do objetivo principal a ser alcançado com o manejo proposto. Entretanto, o principal problema enfrentado trata da seleção dos indicadores adequados a serem medidos bem como da inadequação dessas propostas à condição específica de cada ambiente considerado. Esta situação torna-se ainda mais alarmante quando se trata de ecossistemas aquáticos, já que os trabalhos realizados têm se concentrado nos impactos sobre o solo e a vegetação, e seus indicadores (KUSS, 1990). 


\subsection{A aplicabilidade de bioindicadores no monitoramento de ecossistemas aquáticos}

Conforme verificado por Magro et al. (2001) e Domingos (2002), as variáveis físicas e químicas da água não respondem satisfatoriamente aos impactos da visitação pública. Por outro lado, o emprego de organismos aquáticos parece fornecer informações mais consistentes em monitoramentos desse tipo de atividade (TAYLOR \& ERMAN, 1980; SABINO \& ANDRADE, 2002; SABINO \& ANDRADE, 2003, SABINO, MEDINA-JR, ANDRADE, 2005).

A história da determinação da qualidade das águas superficiais baseada em indicadores biológicos de poluição começou há mais de um século com Kolenati (1848) e Cohn (1853) apud De Pauw \& Vanhooren (1983). Pressupõe-se que animais, plantas, microrganismos e sua complexa interação com o meio ambiente respondam de maneira diferenciada às modificações da paisagem, inclusive àquelas causadas pela atividade humana (RICHARDSON, 1987; SZARO \& JOHNSTON, 1996). No caso da avaliação da qualidade da água, embora análises químicas indiquem a existência em potencial de uma condição perturbadora ao ambiente, elas não indicam os danos causados ao ecossistema. Já os bioindicadores podem integrar espacialmente os efeitos dos impactos e também indicar uma dimensão temporal dos mesmos, corroborando a identificação do estado do sistema (McCARTHY \& SHUGART, 1990).

Para Souza (2001), o estudo de indicadores biológicos, em diferentes níveis de organismos, tem demonstrado ser eficiente em situações em que os dados a colher são difíceis de serem medidos diretamente. Devido a algumas peculiaridades, os impactos do turismo em ambientes aquáticos parece se encaixar na situação descrita pelo autor. Dessa forma, a pesquisa visando à determinação de bioindicadores para esse tipo de impacto é de fundamental importância para o seu gerenciamento.

No que diz respeito à seleção de indicadores biológicos, os mais comuns em ambientes aquáticos são os macroinvertebrados bentônicos, as algas e os peixes (SOUZA, op.cit.). O autor sugere que os ciclos de vida longo, o tamanho, a elevada 
diversidade taxonômica, a facilidade de amostragem e identificação e a sensibilidade a diferentes concentrações de poluentes são os principais atributos responsáveis pela utilização dos macroinvertebrados bentônicos como bons bioindicadores. Essa constatação é corroborada por diferentes trabalhos que têm buscado avaliar os impactos antrópicos sobre esses organismos, considerando diferentes situações, tais como desmatamento, assoreamento e atividade agrícola (GUERESCHI, 1999; FERREIRA, 1998; ROQUE \& TRIVINHO-STRIXINO, 2000), dentre outros. Assim, essa comunidade pode ser empregada como indicadora dos impactos diretos e indiretos promovidos nos ecossistemas aquáticos pela visitação pública, como aberturas de clareiras na mata ciliar, a supressão ou redução de bancos de macrófitas e modificações do substrato pelo pisoteio. Além disso, poderiam responder à entrada de combustíveis e lubrificantes provenientes de embarcações.

No que se refere às algas, o autor atribui a sua importância como bioindicador à sua característica de responder prontamente a eventos de enriquecimento por nutrientes devido ao seu ciclo de vida curto. Nesse caso, os descritores de biomassa, como clorofila a e peso seco, são as principais variáveis a serem medidas (SOUZA, 2001). Deve ser destacado, entretanto, que em ambientes lóticos de baixa ordem, a distribuição das macroalgas possui grande importância prática em programas de biomonitoramento (JOHN \& JOHNSON, 1991; NECCHI et al., 1994; NECCHI et al., 1995; BERTUGACERQUEIRA, 1999). É evidente que o crescente destaque das macroalgas como bioindicadores está relacionado aos atributos ecológicos do grupo, bastante semelhantes aos dos macroinvertebrados bentônicos. Nesse caso, qualquer evento que promovesse a entrada ou redisponibilização de nutrientes para a coluna d'água, poderiam ser detectados.

O papel dos peixes como indicadores biológicos, por sua vez, está relacionado a sua alta mobilidade, seu principal atributo indicador. A partir dessa característica, é possível estabelecer uma relação entre a presença ou ausência desses organismos a uma possível modificação do meio. Além disso, esses organismos ocupam posições 
chave na cadeia trófica do ecossistema, podendo denunciar alterações na estrutura biótica desses ambientes (LOWE-McCONNELL, 1999). Pesquisas bem direcionadas envolvendo essa taxocenose, a exemplo das desenvolvida por Sabino \& Andrade (2003) no rio Baia Bonita, Mato Grosso do Sul, poderiam ser úteis ao estabelecimento de limites aceitáveis de uso em ambientes aquáticos.

Assim, o presente trabalho teve o objetivo de avaliar os impactos ambientais do uso público em ecossistemas aquáticos através de um estudo de caso no rio Formoso (Bonito, Mato Grosso do Sul, Brasil), segundo uma abordagem exploratória e descritiva (DENCKER, 2002). O enfoque principal da pesquisa foi o de caracterizar os impactos provocados pelas diferentes modalidades de uso público no rio Formoso, considerando o emprego de variáveis físicas e biológicas como indicadoras do impacto da visitação pública em um período de alta temporada, carnaval de 2006. Complementarmente, para melhor compreender a relação entre os impactos impressos no ambiente e o uso predominante na região, foram caracterizados aspectos da relação dos empreendimentos turísticos com os ecossistemas aquáticos no Planalto da Bodoquena, a estrutura dos empreendimentos turísticos abertos ao uso público ao longo do rio Formoso e o perfil e aspectos da percepção ambiental dos visitantes desses empreendimentos.

A tese está estruturada em seis capítulos, que abordam em uma ordem lógica os temas tratados, incluindo a presente organização: 1) Introdução geral, estado da arte dos temas envolvidos na pesquisa e apresentação dos objetivos; 2) Descrição do material e métodos empregados na condução do trabalho em suas diferentes etapas, incluindo breve descrição da área de estudo; 3) Análise da demanda da atividade turística por ecossistemas aquáticos no Planalto da Bodoquena, adequação ao processo de licenciamento e caracterização da estrutura e usos ao longo do rio Formoso; 4) Caracterização da visita e dos visitantes ao longo do rio Formoso; 5) Caracterização dos impactos ambientais do uso público no rio Formoso através do emprego de indicadores físicos e biológicos; 6) Considerações finais sobre o impacto da visitação pública no rio Formoso e recomendacões. 


\section{Material e métodos}

\section{1. Área de estudo}

O Planalto da Bodoquena situa-se na região sudoeste de Mato Grosso do Sul (Figura 1) e atua como divisor de águas entre a bacia hidrográfica do rio Paraguai (oeste) e as sub-bacias do rio Apa (sul) e do rio Miranda (leste) (BRASIL, 1992). Trata-se de um conjunto de relevos serranos de caráter residual dispostos no sentido norte-sul, onde a Serra da Bodoquena se destaca como bloco mais representativo, formação com cerca de $200 \mathrm{~km}$ de comprimento e $65 \mathrm{Km}$ de largura (ARAÚJO et. al, 1982).

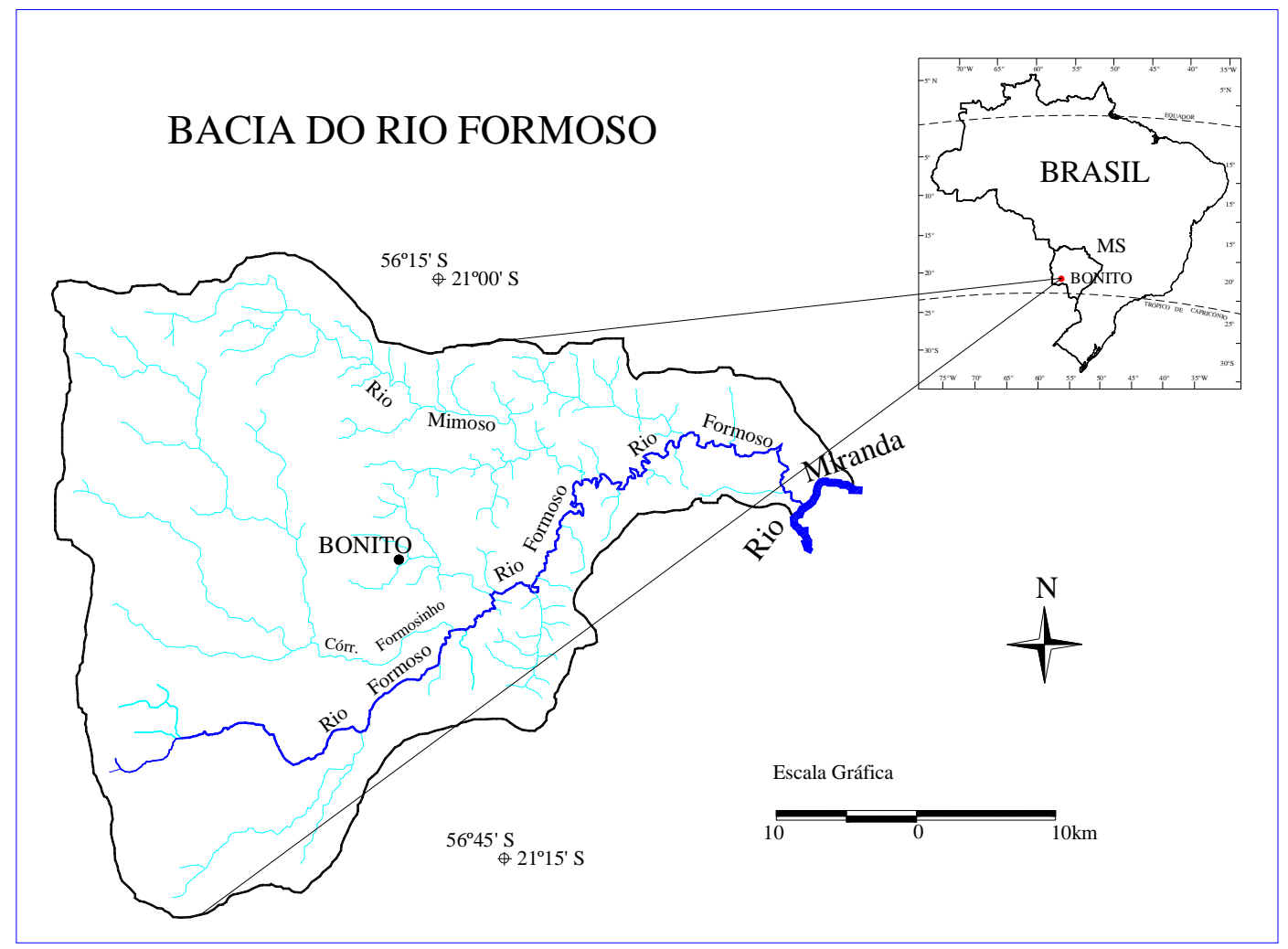

Figura 1. Localização da bacia hidrográfica do Rio Formoso, município de Bonito, Mato Grosso do Sul, Brasil Fonte: adaptação de Rio Formoso (2007) - Laboratório de Geoprocessamento UNIDERP

O Planalto da Bodoquena é um maciço rochoso elevado, com altitudes variando entre 450 e 650 metros, onde praticamente não ocorreu desenvolvimento do solo. A 
cobertura vegetal da região é formada por frações dos domínios morfoclimáticos do Cerrado, Mata Atlântica e Chaco Paraguaio, bem como das áreas de transição correspondentes entre eles (AB'SABER, 1977). Ocorrem formações de florestas semidecíduas, cerrados, áreas rupestres e matas de galeria (HUECK \& SEIBERT, 1981).

Os principais cursos d'água do planalto são o rio Formoso, rio da Prata, rio Perdido e rio Salobra (Figura 1). Todos esses cursos d'água nascem em maciços calcários da Serra da Bodoquena e drenam terrenos também calcários denominados carste, formação predominante no Planalto (BOGGIANI, 1999). O calcário presente na região é extremamente puro e solúvel e, ao se diluir nos ambientes aquáticos, além de contribuir com material isento de impurezas, adsorve e decanta as poucas impurezas presentes tornando suas águas altamente transparentes, com aspecto cristalino. Esse mesmo processo que limpa a água promove a formação de camadas de sedimento bastante inconsolidado e sensíveis no fundo dos ambientes aquáticos, devido ao contínuo processo de decantação de sólidos de diferentes granulometrias, principalmente nos trechos de menor velocidade e turbulência da água.

O calcário dominante na região também é o principal responsável pela diversidade de formações e habitats presentes nos ambientes aquáticos. As rochas calcárias encontram-se em contínuo processo de diluição, permitindo a formação de fraturas por onde a água se infiltra, em locais conhecidos como sumidouros, escoam sob a forma de rios subterrâneos e emergem mais adiante formando as chamadas surgências ou olhos d'água.

A precipitação do carbonato, além de contribuir com a limpidez da água, promove a formação de incrustações calcarias no fundo dos ambientes aquáticos e das chamadas tufas calcárias. Com a deposição contínua de carbonatos, as tufas calcárias crescem formando cachoeiras e barramentos naturais dos rios. Essas formações (Figura 2) são exclusivas de regiões cársticas e representam habitats únicos e sensíveis, facilmente sujeitos a sofrer desequilíbrio sob intervenção antrópica. 
A unicidade e beleza das diversas formações presentes no Planalto da Bodoquena, em especial dos ecossistemas aquáticos, tornam esses ambientes altamente atraentes à visitação pública, o que levou a EMBRATUR a conferir à região o status de Pólo de Ecoturismo do Brasil (EMBRATRUR, 1999).

Para realização do presente estudo de caso foi considerado o rio Formoso (Figura 1), cuja bacia hidrográfica, de $1.334 \mathrm{Km}^{2}$, localiza-se na região central do município de Bonito, Mato Grosso do Sul, Brasil. O Rio Formoso apresenta cerca de $100 \mathrm{Km}$ de extensão, e possui todo o seu curso, de nascente a foz, inserido em áreas rurais do município de Bonito. Apresenta características típicas para os cursos d'água do Planalto da Bodoquena, com águas transparentes e grande diversidade de habitats subaquáticos que abrigam macrófitas aquáticas, algas macroscópicas e várias espécies de peixes facilmente visualizáveis (Figura 3). 

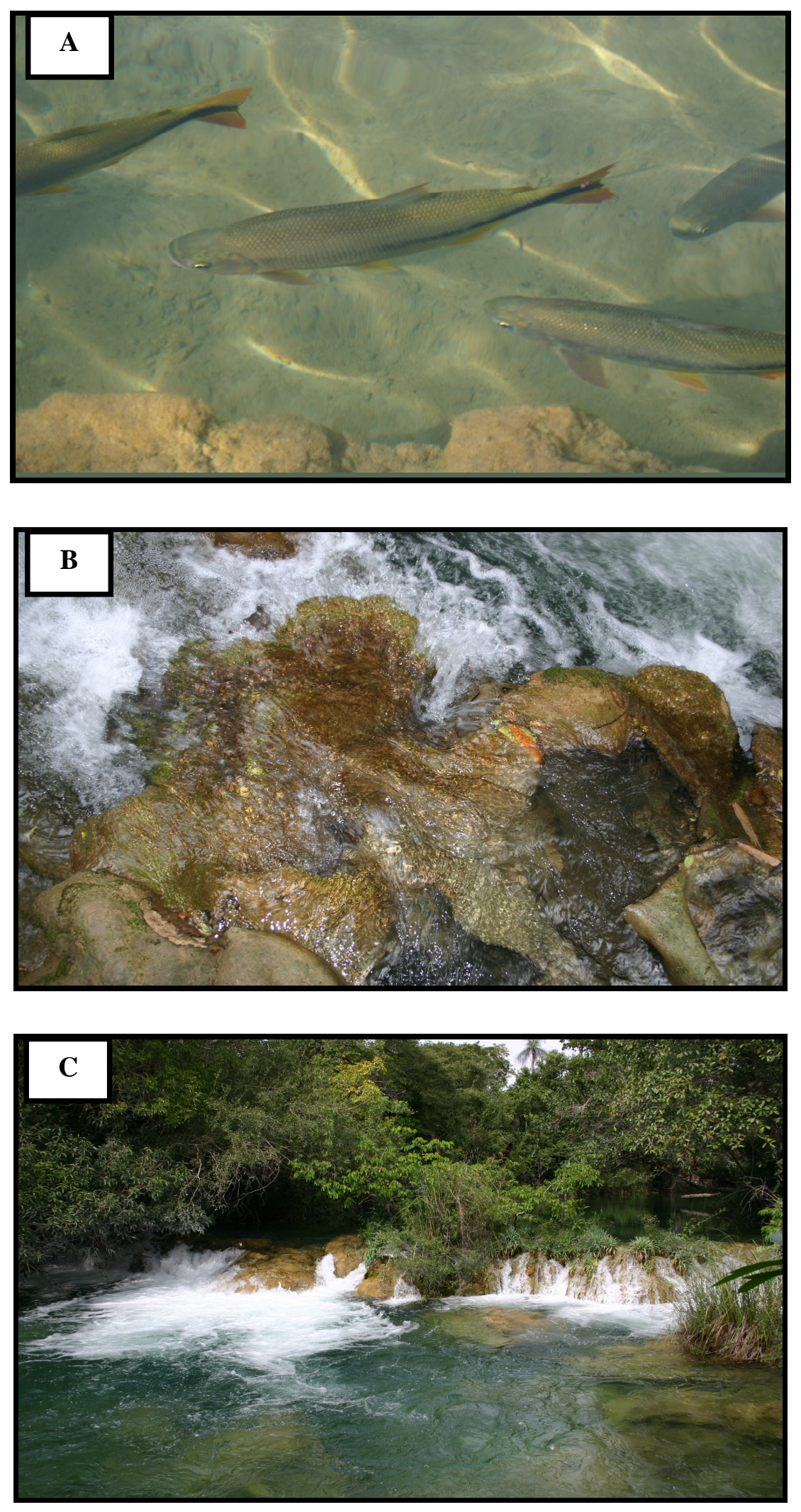

Figura 2. Formações em ambientes aquáticos tipicamente encontradas no Planalto da Bodoquena: A - sedimento inconsolidado; B - incrutrações calcárias subaquáticas; C - Tufas calcárias (Fotos: Paulino Medina) 


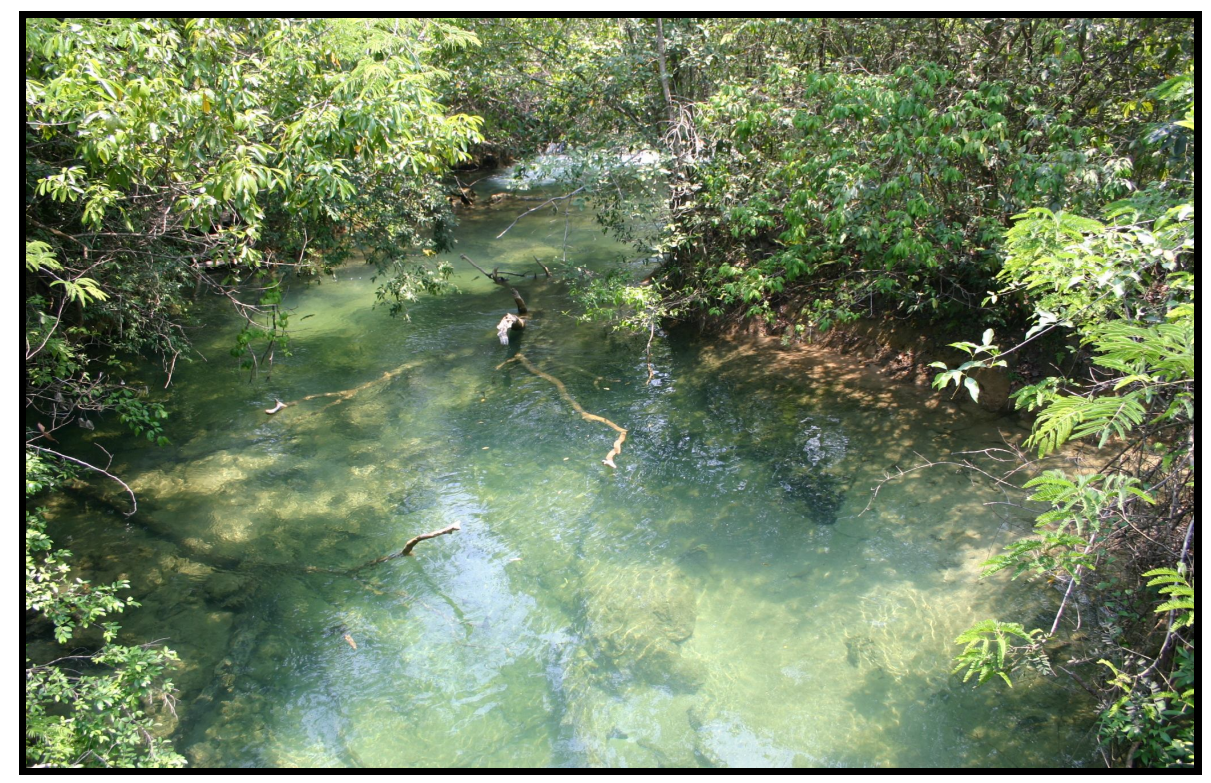

Figura 3. Trecho médio do rio Formoso visto do alto, onde se observa a grande transparência da água e a alta integridade da vegetação ribeirinha e diversidade de habitats aquáticos. (Foto: Paulino Medina)

Além da pressão da visitação pública e ocupações irregulares de suas margens com construções de veraneio, o rio Formoso sofre com a pressão de atividades agropecuárias em sua bacia e com o lançamento pontual, em seu trecho médio, dos efluentes domésticos do município após tratamento. A despeito de todos esses impactos, o ecossistema ainda exibe características de um ambiente natural com alto grau de conservação. Devido a sua localização, beleza cênica e estrutura de visitação instalada, o rio Formoso é considerado um dos principais sítios naturais que atrai visitantes à região.

O presente estudo foi conduzido em todos os trechos do rio Formoso que apresentavam, em suas margens, empreendimentos de turismo abertos à visitação pública no período do estudo. Cada trecho foi considerado como uma estação de amostragem. Para se preservar a identidade dos empreendimentos estudados, estes foram tratados apenas como estações de amostragem, nomeados com letras de A a P. Assim, os trechos do rio Formoso e os empreendimentos equivalentes selecionados para o estudo receberam as mesmas denominações. Em uma das estações (estação C), 2 
empreendimentos fazem uso do rio para visitação pública, um na margem esquerda e outro na margem direita, ambos desenvolvendo as mesmas atividades de visitação. Nesse caso, os empreendimentos foram nomeados C1 e C2.

De todos os empreendimentos inseridos às margens do rio Formoso, apenas dois não foram incluídos no estudo. Dois deles não estavam operando no ambiente aquático no período estudado e o terceiro centraliza suas atividades em um afluente do rio Formoso. Nesse caso, o rio Formoso tem participação bastante pequena nas atividades de visitação, sendo utilizado apenas para travessia, motivo pelo qual se optou por excluir tal empreendimento do presente estudo. Ao todo, foram estudadas 15 estações (trechos do rio), incluindo 16 empreendimentos.

\subsection{Pesquisa documental}

Para se compreender a pressão dos empreendimentos turísticos sobre os ecossistemas aquáticos no contexto da demanda por atrativos naturais no Planalto da Bodoquena e para se conhecer o grau de adequação desses empreendimentos ao processo de licenciamento ambiental, foi executado um extenso levantamento documental junto às entidades governamentais e não governamentais ligadas ao turismo no estado de Mato Grosso do Sul, incluindo: SEMA/IMAP (Secretaria de Estado de Meio Ambiente e Recursos Hídricos/Instituto de Meio Ambiente Pantanal), FUNDTUR (Fundação de Turismo de Mato Grosso do Sul), ATRATUR (Associação dos Atrativos Turísticos de Bonito e Região), ISSQN (Imposto Sobre Serviços de Qualquer Natureza) do Município de Bonito, Secretaria Municipal de Turismo, Indústria e Comércio de Bonito, Secretaria de Turismo do Município de Bodoquena, Prefeitura Municipal de Bonito e IBGE (Instituto Brasileiro de Geografia e Estatística). Foram tabulados todos os empreendimentos de turismo desenvolvido em áreas rurais (e que utilizam de alguma forma ambientes naturais em suas atividades) de Mato Grosso do Sul registrados em, ao menos, um dos órgãos oficiais listados acima. Em alguns casos, o licenciamento foi atribuído à atividade. Nesse caso, a atividade foi tratada como empreendimento para 
efeito de tabulação. Os empreendimentos não registrados em órgãos oficiais, mas que estavam localizados às margens do rio Formoso e fizeram parte do estudo de caso, foram incluídos na amostra. O levantamento foi executado no período de abril a dezembro de 2006.

De acordo com os empreendimentos verificados e atividades desenvolvidas por estes, foi possível obter a freqüência relativa das atividades desenvolvidas e dos recursos naturais explorados, os quais foram apresentados na forma de gráficos. A análise dos dados foi feita buscando-se evidenciar que tipo de atividades são mais executadas e a demanda destas pelos recursos naturais da região do Planalto da Bodoquena. As atividades desenvolvidas foram classificadas de acordo com suas características, estrutura utilizada e impactos causados no meio.

De acordo com a Secretaria de Meio Ambiente do Estado de Mato Grosso do Sul, através da Resolução SEMADES 331/98 (SEMADES, 1998), em todo o estado, os empreendimentos de turismo ficam sujeitos ao licenciamento ambiental quando situados e/ou praticados na zona rural, nas áreas de proteção de mananciais, nas Unidades de Conservação e no entorno destas. Dentro desse contexto, optou-se por considerar como universo de análise todos os empreendimentos desenvolvidos no meio rural no estado.

Levou-se em consideração, ainda, o fato de que no Mato Grosso do Sul, os empreendimentos de turismo situados no meio rural estão baseados principalmente em ambientes naturais. Todavia, como alguns empreendimentos se utilizam ao mesmo tempo de ambientes naturais e de outros recursos não naturais em suas atividades, optou-se por tratar o conjunto como turismo rural e não turismo de natureza. Em situações específicas, quando o texto refere-se a empreendimentos ou atividades baseados apenas em ambientes naturais, estes são abordados como turismo de natureza.

Para o diagnóstico da situação de legalidade ambiental dos empreendimentos de turismo situados no Planalto da Bodoquena, foram levantados dados quantitativos (e qualitativos sempre que possível) referentes aos empreendimentos que se encontram 
cadastrados no banco de dados da SEMA/IMAP (Secretaria Estadual de Meio Ambiente/Instituto de Meio Ambiente Pantanal), no período de janeiro de 2003 a dezembro de 2006. Destes, foram verificados aqueles que se encontram em alguma fase do processo de licenciamento ambiental (licenciados ou em licenciamento).

Os dados desse tema fizeram parte do trabalho final de conclusão de curso intitulado "Demanda dos empreendimentos turísticos por atrativos naturais e adequação às exigências de licenciamento ambiental: estudo de caso no Planalto da Bodoquena, Mato Grosso do Sul, Brasil", desenvolvido pela acadêmica Ana Paula Braga Elisei, do curso de Ciências Biológicas da UNIDERP (Universidade para o Desenvolvimento do Estado e da Região do Pantanal), sob orientação do autor desta tese.

Para se conhecer a dinâmica do fluxo turístico em Bonito, foram feitas consultas ao banco de dados do ISSQN (Imposto Sobre Serviço de Qualquer Natureza) e à Secretaria Municipal de Turismo, Indústria e Comércio do município. Foram considerados dados referentes à visitação ocorrida nos anos de 2003, 2004 e 2005. As informações foram tabuladas e analisadas através de estatística descritiva, com apresentação dos dados na forma de gráficos.

\subsection{Coleta de dados em campo e procedimentos de obtenção dos descritores das variáveis}

Os dados referentes à caracterização da visita e dos visitantes e as variáveis bióticas e abióticas empregadas como indicadoras dos impactos ambientais da visitação foram coletados no período de carnaval de 2006, pela equipe do Laboratório de Biodiversidade e Conservação de Ecossistemas Aquáticos da UNIDERP e colaboradores.

O período de carnaval foi escolhido por representar um dos picos de visitação à região, quando a pressão da visita aos atrativos se concentra devido ao feriado nacional. Assumiu-se que nesse período os impactos impressos pelo uso público nos 
ecossistemas aquáticos da região são pronunciados e de mais fácil detecção e caracterização.

As informações sobre a estrutura e funcionamento dos empreendimentos de visitação pública, representados pelas estações de coleta foram obtidas em expedições de campo realizadas nas semanas seguintes à do carnaval, em períodos de baixa temporada.

\subsubsection{Descrição estrutural e funcional das estações de amostragem enquanto empreendimento de visitação pública}

Em cada estação de amostragem foi realizada uma descrição dos empreendimentos, considerando-se os usos e estrutura de facilitação ao uso público disponível. A descrição foi efetuada buscando-se avaliar as interferências decorrentes da implantação e manutenção do empreendimento sobre o rio e sua zona ribeirinha. Para isso, considerou-se os seguintes descritores:

- $\quad$ Principal atividade desenvolvida no empreendimento e no rio Formoso, definido a partir da demanda de visitantes pela atividade;

- Uso do rio Formoso e sua zona ribeirinha - extensão total do rio Formoso utilizada para visitação pública, considerando-se o canal do rio e sua Área de Preservação Permanente - APP - na zona ribeirinha (faixa de até $50 \mathrm{~m}$ da borda do canal $\left.^{1}\right)$;

- Ocupação da barranca do rio - extensão total da barranca ocupada, obtida através da medição longitudinal da barranca (até 1,0m da borda do canal) onde ocorreu substituição da formação natural (serrapilheira, raízes e vegetação) por estruturas utilizadas para a visitação pública, incluindo concreto, madeira ou cobertura de gramíneas exóticas;

\footnotetext{
1 Foi considerada como APP a área definida na Lei Orgânica do Município de Bonito, que proíbe o desmatamento, a descaracterização e qualquer outro tipo de degradação no trecho de cinqüenta metros das margens de todos os rios e mananciais do município.
} 
- $\quad$ Ocupação da mata ribeirinha - extensão total da mata ribeirinha alterada para implantação da visitação pública. O grau de ocupação foi determinado através da largura da APP mantida com mata ribeirinha nativa. Em cada estação as classes de ocupação foram definidas como inadequada (quando foi mantida mata nativa em uma faixa superior a $30 \mathrm{~m}$ e inferior a $50 \mathrm{~m}$ de largura ou quando a APP foi ocupada apenas com a implantação de trilhas e estruturas de baixa alteração), muito inadequada (quando foi mantida mata nativa em uma faixa entre $5 \mathrm{~m}$ e $30 \mathrm{~m}$ de largura ${ }^{2}$ ) ou_extremamente inadequada (quando foi mantida mata nativa em uma faixa de apenas $5 \mathrm{~m}$ de largura ou menos);

- $\quad$ Capacidade do empreendimento em reduzir a concentração de visitantes do ambiente aquático - definida pela capacidade das estruturas recreativas localizadas fora do ecossistema aquático (bares, salas de jogos, quadra esportiva, piscinas e outros) em absorver o público visitante. Essa capacidade foi determinada pela proporção de visitantes em relação à capacidade máxima de visitantes suportada pelo empreendimento. Em cada estação, essa capacidade foi classificada em alta (acima de 75\%), média (entre 25 e 75\%) e baixa (inferior a $25 \%$ ).

\subsubsection{Descritores da visita e dos visitantes}

Os dados relativos à caracterização da visita e dos visitantes foram obtidos através de um questionário (Anexo 1), composto por perguntas abertas e fechadas, visando à obtenção de informações qualitativas e quantitativas (TAKAHASHI, 1987; WATSON et al. 1992; DENCKER, 2002). Os questionários foram elaborados de forma a permitir a caracterização de aspectos da visita e do perfil e percepção ambiental dos visitantes.

A percepção do visitante foi avaliada a partir das respostas sobre o grau de impacto considerado para as seguintes ações/interferências no meio: saltar no rio; retirar

\footnotetext{
${ }^{2}$ Estudos indicam que a faixa ideal da mata ribeirinha para desempenho da função ecológica de proteção do ecossistema aquático varia entre $3 \mathrm{~m}$ e $30 \mathrm{~m}$, com um valor aceitável de 30 metros na maioria dos casos. No presente estudo, a ocupação da faixa de $30 \mathrm{~m}$ da mata foi considerada muito inadequada, enquanto a manutenção de menos de $10 \%$ da APP legal foi considerada extremamente inadequada.
} 
a vegetação ou outro material do fundo do rio; entrar na água usando protetor solar, bronzeador ou hidratante; tocar o fundo do rio com os pés; subir ou deslizar sobre tufas calcárias ("cachoeiras"); deixar lixo fora da lixeira; pisar sobre pequenas plantas na margem; abrir trilhas na margem do rio; som alto (Anexo 1).

A partir da percepção ambiental dos visitantes, estabeleceu-se o grau de exigência ambiental desses visitantes para cada empreendimento, conforme pontuação atribuída às alternativas de respostas (Quadro 1). Para cada interferência ambiental obteve-se o grau de exigência ambiental do visitante multiplicando-se a pontuação atribuída a cada alternativa pela proporção de respostas obtidas.

Quadro 1: Pontuação atribuída às repostas dos visitantes em relação à percepção dos impactos ambientais provocados pelas diferentes atividades relacionadas à visitação pública

\begin{tabular}{|c|c|}
\hline $\begin{array}{c}\text { Categoria de } \\
\text { percepção ambiental } \\
\text { dos impactos }\end{array}$ & $\begin{array}{c}\text { Pontuação } \\
\text { atribuída como } \\
\text { grau de exigência } \\
\text { ambiental }\end{array}$ \\
\hline $\begin{array}{c}\text { Não causa } \\
\text { impacto }\end{array}$ & 0 \\
\hline $\begin{array}{c}\text { Causa pouco } \\
\text { impacto }\end{array}$ & 1 \\
\hline $\begin{array}{c}\text { Causa muito } \\
\text { impacto }\end{array}$ & 2 \\
\hline
\end{tabular}

O somatório das maiores pontuações (2) resultou, para cada empreendimento, em um valor que determinou o "grau de exigência ambiental máximo" (Quadro 2), correspondente a $100 \%$ do valor possível de ser alcançado. O somatório da pontuação real alcançada por cada empreendimento foi considerado como "grau de exigência ambiental alcançado". Comparando-se o "grau de exigência ambiental alcançado" com o "grau de exigência ambiental máximo" obteve-se o percentual de exigência ambiental dos visitantes para cada empreendimento estudado. As categorias de exigência ambiental foram estabelecidas conforme os intervalos de percentis máximos alcançados e variaram de exigência ambiental muito baixa a exigência ambiental muito alta (Quadro 2). 


\begin{tabular}{|c|c|}
\hline $\begin{array}{c}\text { Percentis do grau de exigência ambiental } \\
\text { máximo }\end{array}$ & $\begin{array}{c}\text { Categoria de exigência ambiental do } \\
\text { visitante na localidade }\end{array}$ \\
\hline$\leq 35 \%$ & Muito baixa \\
\hline $36-50 \%$ & Baixa \\
\hline $51-75 \%$ & Média \\
\hline $76-90 \%$ & Alta \\
\hline$\geq 90 \%$ & Muito alta \\
\hline
\end{tabular}

\subsubsection{Amostragem}

Para testar a confiabilidade do instrumento e avaliar possíveis necessidades de ajustes, o questionário foi previamente avaliado através de pesquisa exploratória com amostras aleatórias de visitantes (KERLINGER, 1980; DENCKER \& VIÁ, 2001). A precisão das variáveis adotadas como descritoras do perfil do visitante foi obtida a partir da pesquisa exploratória.

Para uma estimativa adequada da amostra foi empregado o método da amostra aleatória estratificada para estimar uma proporção de população finita. Para tanto, foram considerados dados históricos referentes à freqüência de visitação aos empreendimentos localizados ao longo do rio Formoso no período de carnaval, nos últimos três anos, obtidos junto à administração de cada empreendimento.

O número de pessoas a serem investigadas foi determinado através de um método probabilístico que, segundo Fonseca e Martins (1994), exige que cada elemento da população possua a mesma probabilidade de ser selecionada para a entrevista. Tratase do método que garante cientificamente a aplicação das técnicas estatísticas de inferências ou induções sobre a população a partir do conhecimento da amostra.

Assim, se $\mathrm{N}$ for o tamanho da população, a probabilidade de cada elemento será $1 / \mathrm{N}$.

Como se trata de uma variável nominal, com população indefinida, e não há registro de pesquisa que trata do tema na área em estudo, para que se pudesse escolher 
uma amostra usando parâmetros já calculados na referida pesquisa, tais como o desvio padrão, calculamos o número de elementos da amostra usando a seguinte fórmula matemática:

$$
n=\frac{z^{2} \hat{p} \hat{q}}{e^{2}}
$$

sendo

$\mathrm{n}$ = número de elementos da amostra;

$z=$ abscissa da curva normal padrão, fixado o nível de confiança em $95 \%(z=1,96)$;

$p$ = estimativa da verdadeira proporção de um dos níveis da variável escolhida;

$$
\text { - } \hat{q}=1-\hat{p}
$$

e = erro amostral, expresso em decimais (máxima diferença que o pesquisador admite suportar $\hat{p}_{\text {entre verdadeiro e }} \hat{p}$ estimado).

Dentre várias técnicas de amostragem probabilística para a composição dos elementos da amostra, utilizamos segundo Fonseca e Martins (1994), a amostragem casual ou aleatória simples, sendo este o processo mais elementar e freqüentemente utilizado. A amostragem probabilística é uma técnica especial para recolher amostras, que garante, tanto quanto possível, o acaso na escolha.

Em nosso trabalho de pesquisa, o problema consiste em determinar uma amostra de pessoas de uma população infinita com as seguintes considerações:

$$
\begin{array}{ll}
-\mathrm{z}=1,96 \\
\text { - } \quad \hat{p}=0,50 \text { (pior caso) } \\
\hat{q}=0,50 \\
\text { - } \quad \mathrm{e}=0,055(5,5 \%) .
\end{array}
$$

Substituindo os valores na fórmula da amostragem obtém-se $n=317,48$, isto é, a amostra deve constar de, no mínimo, 318 pessoas a serem investigadas. 
A composição da amostra foi determinada usando amostragem estratificada, considerando-se a participação relativa de cada estação de amostragem (estratos) na população. Após a determinação dos 16 estratos, selecionou-se uma amostra aleatória de cada subpopulação (estrato).

\subsubsection{Indicadores de impacto da visitação pública}

Através de variáveis que atuam como potenciais indicadoras das condições ambientais da água e do sedimento (incluindo macroinvertebrados bentônicos como possíveis bioindicadores) e de alterações na estrutura física dos ecossistemas naturais do rio Formoso, foi efetuada uma avaliação dos impactos relacionados à visitação pública sobre o ecossistema aquático. Foi considerado como ecossistema aquático a área molhada do rio (ocupada pelo espelho d'água) e sua barranca.

\subsubsection{Alterações na estrutura física do ecossistema}

Foi realizada uma avaliação descritiva da integridade física do rio Formoso com o emprego de um protocolo de avaliação da estrutura física de ecossistemas, formulado segundo inspirações obtidas a partir dos trabalhos de HANNAFORD et al. (1997), BARBOUR et. al. (1999) e CALLISTO et al. (2002). A avaliação foi conduzida ao longo de cada estação, considerando-se toda a extensão utilizada para visitação pública nos empreendimentos. Foi avaliado o grau de impacto sobre o canal do rio e sobre as margens utilizadas pela visitação pública em cada estação, através de descritores da diversidade e estabilidade de fundo, estabilidade das tufas calcárias e das margens do ambiente aquático. O grau de impacto sobre a estrutura física do ecossistema foi obtido através das seguintes técnicas:

\section{- Diversidade e estabilidade de substratos de fundo}

Avaliado através de observações subaquáticas feitas por meio de flutuação utilizando-se roupa de neopren e snorkel. Cada estação foi avaliada através das 
características registradas em quadrantes delimitados pelo raio de visão do observador. Foram computados apenas os quadrantes que exibiam algum grau de alteração recente no fundo como rompimentos de galhos e deslocamento de troncos submersos, pisoteio ou ressuspensão de folhedo, remoção de macrófitas aquáticas fixas, rochas ou seixos e erosão do fundo por pisoteio. As informações obtidas em cada quadrante computado foram anotadas em placa de acrílico com uso de lápis de grafite. O grau de impacto de cada estação foi obtido através da somatória das pontuações atribuídas a cada quadrante, conforme Quadro 3. A ausência de impacto foi pontuada com o valor 0,0 (zero);

\section{- Agressões a tufas calcárias}

Cada tufa calcária presente no trecho utilizado pelo empreendimento e que exibiu algum grau de alteração física foi avaliada através de observação visual direta. A alteração sobre superfície de cada habitat foi verificada observando-se a ocorrência de erosões pontuais (com largura e comprimento máximo inferiores a $0,5 \mathrm{~m}$ ), erosões em trilheiros (alongadas e com largura inferior a $0,5 \mathrm{~m}$ ) e clareiras (erosões largas com formato variado, geralmente circular, cuja área foi calculada de acordo com a figura geométrica mais semelhante). O impacto sobre cada tufa foi pontuado conforme Quadro 3 e o dado anotado em placa de acrílico com lápis de grafite. O grau de impacto em cada estação foi obtido a partir da somatória das pontuações atribuídas ao conjunto das tufas avaliadas. A ausência de impacto foi pontuada com o valor 0,0 (zero);

\section{- Estabilidade das barrancas}

Foi considerada como barranca o dique marginal paralelo ao rio que ocupa a faixa de até $1 \mathrm{~m}$ da borda do ambiente aquático, incluindo o terreno vertical até o contato com a lâmina d'água. Mediante observação direta, foram verificadas e anotadas todas as ocorrências de agressão à barranca nas margens utilizadas pela visitação pública em cada estação de amostragem. Foram considerados como agressões os pontos de erosão no solo ou a simples exposição da superfície do solo com ausência de cobertura vegetal 
(serrapilheira ou plantas rasteiras). Cada ocorrência foi classificada e pontuada individualmente conforme Quadro 3 e o grau de impacto na estação obtida pela somatória de todos os pontos atribuídos às ocorrências de impacto registradas. As ocorrências de solo com superfície exposta foram consideradas até o limite de 10 metros de extensão paralela ao rio, sendo que nos casos em que a extensão era superior a esse limite foi considerada como uma nova seção cada 10 metros linear de impacto. A ausência de impacto foi pontuado com o valor 0,0 (zero).

Quadro 3: Protocolo de pontuação aplicado na avaliação de impactos a habitats do rio Formoso nas estações estudadas (Adaptado de HANAFORD et al., 1997; Barbour et al., 1999 e Callisto et al., 2002).

\begin{tabular}{|c|c|c|c|c|}
\hline \multirow[b]{2}{*}{ Indicador } & \multicolumn{4}{|c|}{ Verificadores do grau de impacto } \\
\hline & $\begin{array}{c}\text { Insignificante } \\
1 \text { ponto }\end{array}$ & $\begin{array}{l}\text { Moderado } \\
3 \text { pontos }\end{array}$ & $\begin{array}{c}\text { Alto } \\
6 \text { pontos }\end{array}$ & $\begin{array}{c}\text { Severo } \\
10 \text { pontos }\end{array}$ \\
\hline $\begin{array}{l}\text { Estabilidade e } \\
\text { diversidade } \\
\text { de fundo }\end{array}$ & $\begin{array}{l}\text { Mais de } 70 \% \text { do } \\
\text { fundo formado por } \\
\text { troncos } \\
\text { submersos, folhas, } \\
\text { galhos, macrófitas } \\
\text { e outros habitats } \\
\text { estáveis, mas com } \\
\text { alguma evidência } \\
\text { de alteração } \\
\text { recente no } \\
\text { substrato. }\end{array}$ & $\begin{array}{l}40 \text { a } 70 \% \text { do fundo } \\
\text { formado por } \\
\text { conjunto de } \\
\text { habitats estáveis e } \\
\text { diversificado. }\end{array}$ & $\begin{array}{l}\text { Apenas } 20 \text { a } 40 \% \\
\text { do fundo formado } \\
\text { por conjunto de } \\
\text { habitats estáveis e } \\
\text { diversificado. }\end{array}$ & $\begin{array}{l}\text { Menos de } 20 \% \text { do } \\
\text { fundo formado por } \\
\text { conjunto de } \\
\text { habitats estáveis e } \\
\text { diversificado; } \\
\text { substratos } \\
\text { instáveis ou } \\
\text { ausentes. }\end{array}$ \\
\hline $\begin{array}{l}\text { Estabilidade } \\
\text { das tufas } \\
\text { calcárias }\end{array}$ & $\begin{array}{l}\text { Desgaste mínimo } \\
\text { da superfície da } \\
\text { tufa; ocorrência de } \\
\text { até } 2 \text { erosões } \\
\text { pontuais e erosões } \\
\text { em trilheiro com } \\
\text { até } 1 \mathrm{~m} \text { de } \\
\text { extensão }\end{array}$ & $\begin{array}{c}\text { Entre } 2 \text { e } 5 \\
\text { erosões pontuais; } \\
\text { erosões em } \\
\text { trilheiro com } \\
\text { extensão entre } 1 \mathrm{~m} \\
\text { e } 5 \mathrm{~m} \text {; ocorrência } \\
\text { de clareira com até } \\
1 \mathrm{~m}^{2} \text { de área. }\end{array}$ & $\begin{array}{l}\text { Erosão em trilheiro } \\
\text { com extensão } \\
\text { superior a } 5 \mathrm{~m} ; \\
\text { ocorrência clareira } \\
\text { com até } 2 \mathrm{~m}^{2} \text { de } \\
\text { área. }\end{array}$ & $\begin{array}{l}\text { Erosão em trilheiro } \\
\text { com extensão } \\
\text { superior a } 5 \mathrm{~m} ; \\
\text { ocorrência clareira } \\
\text { com mais de } 2 \mathrm{~m}^{2} \\
\text { de área. }\end{array}$ \\
\hline $\begin{array}{l}\text { Estabilidade } \\
\text { das barrancas }\end{array}$ & $\begin{array}{l}\text { Processo inicial de } \\
\text { pisoteio da } \\
\text { vegetação ou } \\
\text { serrapilheira das } \\
\text { barrancas com } \\
\text { menos de } 1 \mathrm{~m} \text { de } \\
\text { solo exposto. }\end{array}$ & $\begin{array}{c}\text { Solo bastante } \\
\text { exposto, sem } \\
\text { cobertura de } \\
\text { serrapilheira ou } \\
\text { vegetação; } \\
\text { superfície do solo } \\
\text { exposto em uma } \\
\text { extensão de 1m a } \\
3 \mathrm{~m} .\end{array}$ & $\begin{array}{c}\text { Ocorrência de } \\
\text { erosão formando } \\
\text { sulcos de até } 0,30 \\
\text { m de largura; } \\
\text { exposição da parte } \\
\text { superior e lateral } \\
\text { de raízes grandes; } \\
\text { extensão da } \\
\text { superfície exposta } \\
\text { entre } 3 \mathrm{~m} \text { e } 6 \mathrm{~m} \text {. }\end{array}$ & $\begin{array}{c}\text { Ocorrência de } \\
\text { erosão formando } \\
\text { sulcos com largura } \\
\text { superior a 0,30 m; } \\
\text { exposição } \\
\text { completa de raízes } \\
\text { grandes; extensão } \\
\text { da superfície } \\
\text { exposta entre } 6 \mathrm{~m} \text { e } \\
10 \mathrm{~m} \text {. }\end{array}$ \\
\hline
\end{tabular}

\section{- Acessos secundários ao rio}


Foram registradas todas as ocorrências de acessos secundários ao rio a partir de uma trilha oficial. O grau de impacto foi avaliado através do número total de ocorrências por estação. A ausência de impacto foi pontuado com o valor 0,0 (zero);

\section{- Presença de resíduos sólidos nas margens}

Os resíduos sólidos presentes na margem em uma faixa de até 2 metros da borda do rio foram quantificados e o impacto na estação classificado de acordo com o volume total de resíduos registrado, de acordo com a seguinte pontuação: 1 ponto - volume

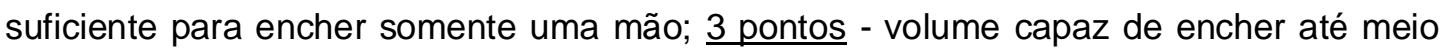

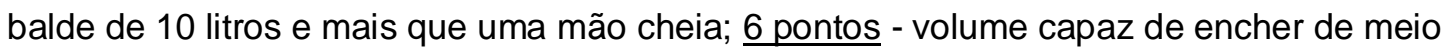
a 1 balde de 10 litros; 10 pontos - volume superior a 1 balde de 10 litros. A ausência de impacto foi pontuado com o valor 0,0 (zero);

\subsubsection{Indicadores das condições da água e do sedimento}

Os dados sobre as condições da água e do sedimento foram obtidos em dois pontos de coleta em cada estação de amostragem.

Os potenciais indicadores da qualidade da água foram avaliados a partir de dados obtidos em dois pontos de coleta em cada estação de amostragem, sendo 1 ponto localizado a montante e outro imediatamente a jusante da área utilizada pelos visitantes no momento da amostragem. A definição de pontos de amostragem situados a montante e a jusante da área de visitação foram estrategicamente estabelecidos de forma a refletir as condições da água sob impacto da visitação e em situação considerada controle, respectivamente. As informações foram obtidas através de medições in loco, com uso de equipamentos portáteis, ou determinados em laboratório a partir de amostras de água coletadas na subsuperfície, com garrafa de Van Dorn, devidamente acondicionadas e transportadas para posterior análise.

Em cada estação de amostragem, o sedimento foi coletado com um pegador de fundo tipo Van Veen em pontos impactados (áreas utilizadas pela visitação pública) e 
pontos controle (áreas com condições semelhantes às impactadas, porém sem uso). Para se obter maior representatividade das áreas impactadas e das áreas controle, em cada uma delas foram realizadas 6 repetições de lançamento da draga de forma aleatória, totalizando 12 pegadas por estação. Para cada ponto, 3 repetições foram utilizadas para avaliação em campo da concentração de material orgânico particulado grosso e 3 repetições foram utilizadas para as análises em laboratório. Para cada porção de 3 repetições, o material foi homogeneizado e retirada uma fração para as análises. As frações a serem analisadas em laboratório foram devidamente acondicionadas em frascos de polietileno, identificados e encaminhadas para análise.

Os procedimentos empregados na análise das variáveis descritoras das condições da água e do sedimento encontram-se sumarizados a seguir.

\subsection{Variáveis descritoras das condições da água}

- Temperatura (ํ) $\mathrm{C}$, pH, oxigênio dissolvido (mg.L-1) e condutividade elétrica $(\mu S . c m-1)$ da água

Foram feitas medições in loco com utilização de sensores digitais portáteis de qualidade da água, incluindo um oxímetro conjugado com termômetro, um pHgâmetro e um condutivímetro, todos da marca Digimed.

\section{- Transparência horizontal da água $(m)$}

Em função da alta transparência da água do rio Formoso, essa variável não pôde ser medida verticalmente como é classicamente praticado em estudos de ambientes aquáticos, pois em praticamente todas as situações a transparência atinge o fundo do ecossistema camuflando as alterações provocadas pela atividade antrópica. Dessa forma, no presente estudo foi medida a transparência horizontal da água a partir da observação subaquática de um disco de metal de $30 \mathrm{~cm}$ de diâmetro, com quadrantes intercalados nas cores preta e branca, para aumentar o contraste e facilitar a sua 
visualização. O disco foi preso a uma corda graduada e disposto horizontalmente ao longo da coluna d'água, sendo seguro a $10 \mathrm{~cm}$ da subsuperfície por uma pessoa enquanto o observador, equipado com snorkel, se distanciava através da corda esticada paralelamente à superfície da água. A distância entre o obsenador e o disco de secchi no momento do desaparecimento do disco era anotado e considerado como valor da transparência horizontal da água, em metros.

\section{- Sólidos totais em suspensão (mg. L-1)}

Os sólidos totais em suspensão na água foram extraídos através da filtragem de volume conhecido de água em filtros de fibra de vidro tipo GF/C com aproximadamente 0,47 $\mu \mathrm{m}$ de porosidade. Os filtros foram encaminhados ao laboratório para execução das análises através do método gravimétrico descrito em Teixeira et. al. (1965), com modificações baseadas em Wetzel \& Likens (1991).

\section{- Nitrogênio orgânico total (mg/L)}

As concentrações de nitrogênio orgânico total foram obtidas em laboratório, de acordo com Golterman et al. (1978).

\section{- Fósforo total ( $\mu \mathrm{g} / \mathrm{L})$}

As concentrações de fósforo total foram obtidas em laboratório, segundo metodologia descrita em APHA (1998).

\section{- Óleos e graxas (mg/L)}

As concentrações de óleos e graxas na água foi obtida em laboratório, segundo metodologia descrita em APHA (1998).

\subsection{Variáveis descritoras das condições do sedimento}


- Concentração de material orgânico particulado grosso (folhedo) no sedimento

Do material homogeneizado, uma fração foi retirada e colocada, sem compactar, em um pote de acrílico transparente, com capacidade de $2 \mathrm{~L}$ e graduado a cada $200 \mathrm{ml}$ (1/10 do volume total do frasco). Com o pote cheio, foi observado o volume total ocupado pelo folhedo, observando-se cada $1 / 10$ de volume do pote e anotando-se participação relativa do folhedo na amostra, em \%.

- Granulometria e concentração de matéria orgânica fina no sedimento (\%).

A análise granulométrica foi realizada utilizando-se sistema de peneiras conforme descrito em APHA (1998), onde se considerou as frações granulométricas de argila a areia fina para determinação da textura granulométrica fina.

A análise de matéria orgânica foi executada através do método de perdas por ignição, calcinando o sedimento seco a $560 \stackrel{\circ}{\mathrm{C}}$ por $1 \mathrm{~h} 30 \mathrm{~min}$, de acordo com rotina do laboratório de Limnologia do Centro de Recursos Hídricos e Ecologia Aplicada/USP, São Carlos.

- Nitrogênio total (\%) e fósforo total $(\mathrm{mg} / \mathrm{Kg})$ no sedimento

As concentrações de fósforo total e nitrogênio total foram obtidas em laboratório, segundo metodologia descrita em APHA (1998).

\subsubsection{Macroinvertebrados bentônicos}

No presente estudo, empregou-se os macroinvertebrados bentônicos como potenciais bioindicadores dos impactos do uso público no rio Formoso. Essa taxocenose foi escolhida por responder aos impactos diretos e indiretos impressos nos habitats de 
fundo dos ecossistemas aquáticos, compartimento sujeito a diferentes graus de interferência derivados do uso público.

Os procedimentos de coleta de dados em campo foram os mesmos empregados na coleta de sedimentos. Os organismos foram coletados através de amostragem integrada, utilizando-se de uma Draga de Van Veen, através de seis (6) pegadas no fundo em cada estação de amostragem, sendo três (3) na área controle e três (3) na área impactada.

As amostras foram previamente triadas em campo e os organismos selecionados em uma rede de $0,37 \mathrm{~mm}$ de abertura de malha. O material coletado foi fixado em formalina a 4\%, acondicionado em potes plásticos e transportado para o laboratório, onde foi efetuada a triagem definitiva sobre uma bandeja transiluminada. Os animais foram separados sob microscópio estereoscópico e fixados em álcool a 70\% para posterior identificação com o auxílio de literatura especializada (MCCAFFERTY,1981; BRINKHURST \& MARCHESE, 1989; PÉREZ, 1989; TRIVINHO-STRIXINO \& STRIXINO, 1995; MERRITT \& CUMMINS, 1996, BOUCHARD, 2004, entre outros) e consulta a especialistas. Devido à carência de informações e manuais de identificação relativos à fauna brasileira, os organismos foram separados em morfotipos e identificados até o nível taxonômico de família, quando possível.

Para cada ponto de amostragem foi obtida a riqueza taxonômica e as densidades absoluta e relativa de organismos representantes de cada táxon registrado, os quais foram aplicados no cálculo do Índice de Diversidade de Shanon-Winer, métricas descritoras da estrutura de comunidades (PIELOU, 1977).

\subsection{Tabulação e análise dos dados}

\subsubsection{Características dos empreendimentos, da visita e dos visitantes}

Os resultados relacionados à demanda dos empreendimentos turísticos por ecossistemas aquáticos no Planalto da Bodoquena, à estrutura dos empreendimentos 
turísticos ao longo do rio Formoso e às características da visita e dos visitantes foram armazenados em banco de dados do programa Access e analisados através de estatística descritiva. Os resultados foram expressos na forma de gráficos e tabelas.

As técnicas de análise estatística descritiva também foram empregadas para se efetuar comparações e correlações entre as informações sobre as características da visita e dos visitantes, obtidas através dos questionários nas diferentes estações de amostragem. O processamento dos dados foi efetuado utilizando-se o Programa Sphinx, licenciado para uso do Instituto de Pesquisas de Preços ao Consumidor - IPC/UNINERP. Os resultados dos cruzamentos foram expressos em tabelas de cruzamentos de dados, sendo os mais importantes apresentados no texto e os demais como anexo, devido ao grande volume de informações. As informações foram analisadas e discutidas considerando-se uma abordagem global para o conjunto dos dados obtidos ao longo do rio Formoso e por grupos de estações amostradas, conforme as principais atividades desenvolvidas.

\subsubsection{Indicadores de impactos da visitação}

Para avaliação dos indicadores de impactos, as estações de coletas foram agrupadas de acordo com a semelhança entre as atividades desenvolvidas pelos empreendimentos. Em função do tipo e grau de contato do visitante com os compartimentos do ecossistema aquático, durante o desenvolvimento das atividades de visitação nos diferentes empreendimentos estudados, agrupou-se as estações de coletas em 3 grupos: 1.Balneários; 2. Passeios de barco, bote e bóia-cros; 3. Banho e flutuação.

Considerando-se os grupos acima, efetuou-se a tabulação e análise estatística das variáveis descritoras das condições ambientais nos quatro compartimentos ambientais estudados (água, sedimento, macroinvertebrados bentônicos e estrutura física do ecossistema) empregando-se a seguinte estratégia:

\section{a. Variáveis abióticas da água e do sedimento}


Para avaliar possíveis padrões entre os pontos de coleta e selecionar variáveis ambientais principais na explicação dos padrões evidenciados, as matrizes com dados abióticos do sedimento e da água foram submetidas à Análise de Componentes Principais. Empregou-se o Programa PAST, gratuitamente disponível no endereço: <http://folk.uio.no/ohammer/past/download.html>.

\section{b. Macroinvertebrados bentônicos}

Para avaliar exploratoriamente possíveis associações entre os pontos de coleta (impacto versus não impacto) e a abundancia total dos diferentes táxons, foi aplicada Análise de Correspondência. Os dados foram previamente logaritimizados (Log10+1) e analisados no programa estatístico PAST.

Para testar o efeito da área submetida à visitação versus área controle (fatores) e das estações de coleta nas variáveis dependentes riqueza de táxons e abundância (total), foi aplicada Análise de Variância com dois critérios. Utilizou-se o pacote $\begin{array}{llll}\text { estatístico } & \text { Biostat } & 3.0, & \text { disponível no }\end{array}$ <http://superdownloads.uol.com.br/download/42/biostat>.

\section{c. Estrutura física do ecossistema}

Os dados que compuseram o Índice de Alteração da Estrutura Física de Ecossistemas (IAEFE) foram obtidos e avaliados através de uma abordagem qualiquantitativa, de forma a descrever e qualificar a integridade física do ecossistema em toda a extensão dos trechos submetidos à visitação pública das estações estudadas. Os resultados foram interpretados de forma global, por grupos de estações e comparativamente entre os grupos, através de estatística descritiva, e apresentados na forma de gráficos e tabelas.

\section{d. Seleção de indicadores}


A seleção de indicadores é um dos tópicos mais complexos no desenvolvimento de sistema de monitoramento, pois depende tanto da resposta e previsibilidade do indicador frente ao impacto quanto de aspectos práticos (e.g. baixo custo de obtenção e análise, facilidade de interpretação).

Neste trabalho, a partir dos resultados evidenciados nas análises estatísticas, foram utilizados os seguintes critérios para a seleção de possíveis indicadores de impactos da visitação pública nas condições estudadas:

\section{e. Seleção por grupos de estações}

Como as estações foram agrupadas em função da semelhança entre as atividades desenvolvidas e as interferências promovidas no ecossistema aquático, os indicadores foram selecionados de forma a representar as condições medidas e analisadas para cada grupo. Assim, os indicadores selecionados para um determinado grupo de estações não representam, necessariamente, bons indicadores para os demais grupos, e vice-versa.

\section{f. Representatividade dos diferentes compartimentos do ecossistema}

Considerando que os eventos ambientais naturais e/ou antrópicos atuam de maneira distinta nos diferentes compartimentos do ecossistema aquático, a detecção de possíveis alterações ambientais no ecossistema é mais eficiente tanto quanto melhor representados estiverem os compartimentos ambientais através dos indicadores empregados na avaliação.

Com base nessa condição, no presente trabalho a seleção de indicadores foi efetuada para cada grupo de variáveis representante de cada compartimento ambiental considerado (abióticas da água, abióticas do sedimento, macroinvertebrados bentônicos e estrutura física do ecossistema), de forma que se contemplasse ao menos um indicador por compartimento. Para tanto, as variáveis foram pontuadas para cada grupo de estações em uma escala de 1 a 5 . Os pontos foram atribuídos às variáveis conforme o 
grau de atendimento a cada critério de seleção (proporcionalmente ao valor máximo possível), sendo que o valor 5 indica a pontuação máxima possível de ser alcançada para cada critério. A escala de 0 a 5 foi escolhida para facilitar a compreensão do nível de atendimento de cada variável aos critérios estabelecidos.

\section{g. Distinção entre as causas da alteração ambiental}

Apenas variáveis que explicaram ao menos parte da variabilidade do padrão impacto versus não impacto foram selecionadas através de PCA e CA e ANOVA. No caso de variáveis explicativas de outros padrões evidenciados das análises de PCA, CA e ANOVA (ex. padrões longitudinais ao longo do rio), embora reconhecidamente importantes para entender os possíveis processos ecológicos relacionados com os impactos de forma sinergética ou indireta, optou-se por desconsiderá-las nessa fase da seleção, pois não estão diretamente envolvidas na explicação do efeito objeto deste estudo (impactos da visitação pública). Para PCA e CA, as variáveis que atenderam a esse critério foram pontuadas de 1 a 5 quanto ao seu peso na distinção dos pontos de impacto versus controle (valores de F). Cada 1/5 da pontuação máxima possível equivale a 1 ponto. No caso de ANOVA, foi atribuída pontuação 5 e 0, para o caso de distinção e não distinção de impacto versus controle, respectivamente. Como essa análise mede a regularidade na mudança, a gradação de valores desse fator foi pontuada pelo critério Regularidade na Resposta.

\section{h. Regularidade na resposta}

Apenas as variáveis que responderam previsivelmente diferenciando as áreas sob uso (impacto) das áreas controle, com regularidade de $80 \%$ para cada conjunto de estações amostradas, foram selecionadas para as etapas seguintes. Foi utilizado este critério restritivo, pois o baixo número amostral de pontos por grupo de estações poderia acarretar em sobrevaloração de variáveis. As variáveis que atenderam a esse critério 
foram pontuadas de 1 a 5 quanto ao número de estações em que variaram regularmente.

Cada 1/5 da pontuação máxima possível equivale a 1 ponto.

\section{i. Complementaridade}

Em casos em que mais de uma variável atendeu a ao menos um dos critérios acima especificados, aplicou-se análise de correlação linear visando a diminuir uma possível redundância e destacar as variáveis não correlacionadas no compartimento. As variáveis que atenderam a esse critério foram pontuadas em função de sua singularidade em relação ao conjunto de variáveis submetidas à análise de correlação: s/ correlação com outra variável $=5$ pontos; correlacionada a apenas 1 outra variável $=3$ pontos; correlacionada a 2 outras variáveis = 1 ponto; correlacionada a mais de 2 outras variáveis = $\mathrm{S} /$ pontuação.

\section{j. Representatividade}

As variáveis submetidas à análise de correlação linear foram pontuadas quanto à sua representatividade do compartimento ambiental, definido pelo número de variáveis com as quais mantém correlação. A pontuação foi estabelecida com base no número de correlações e sua importância relativa em relação ao total de correlações possíveis. Nos casos analisados, cada variável correlacionada equivaleu a 2,5 pontos, 1,25 pontos e 5 pontos para o compartimento condições abióticas da água, condições abióticas do sedimento e macroinvertebrados bentônicos, respectivamente. Os valores foram arredondados para o número inteiro mais próximo.

\section{k. Custo e praticidade}

Todas as variáveis que atenderam aos critérios anteriores foram pontuadas de 0 a 5 quanto às suas características de custo (inversamente proporcional à pontuação) e praticidade na medição e interpretação (diretamente proporcional à pontuação). Os critérios custo e praticidade foram avaliados separadamente. Em casos de possível 
redundância, optou-se por selecionar as variáveis que obtiveram maior pontuação nesse critério, uma vez que este estudo tem como premissa a intenção de gerar produtos realmente aplicáveis à realidade local.

\section{Importância}

Com base na somatória das pontuações obtidas em cada critério de seleção, a variável recebeu uma pontuação final (variando de 0 a 30) representando seu grau de importância enquanto indicadora das alterações ambientais provocadas pela visitação pública. A variável que não atendeu ao critério regularidade na resposta foi desclassificada como potencial indicadora por não atender ao objeto principal deste estudo. A seleção dos indicadores foi efetuada em função do grau de importância obtido por cada variável na matriz de análise. Apenas as variáveis que obtiveram valores iguais ou superiores a $50 \%$ da pontuação máxima de importância (importância $\geq 15$ ) foram selecionadas como indicadoras.

As variáveis descritoras das alterações da estrutura física do ecossistema foram todas selecionadas como indicadoras por terem sido previamente eleitas para comporem o Índice de Alteração da Estrutura Física de Ecossistemas (IAEFE) e por apresentarem regularidade na resposta ao impacto e serem de baixo custo e práticas (fácil medição e interpretação).

3. Atividade turística no Planalto da Bodoquena: demanda por ecossistemas aquáticos, adequação ao processo de licenciamento ambiental e caracterização da estrutura para visitação e dos usos no rio Formoso

3.1. Demanda da atividade turística por ecossistemas aquáticos no Planalto da Bodoquena 
Da análise das características das atividades turísticas desenvolvidas pelos empreendimentos baseados no meio rural no Planalto da Bodoquena, resultou o agrupamento dessas atividades nas seguintes categorias:

- $\quad$ Arvorismo - atividade desenvolvida na copa das árvores;

- Balneário - atividade realizada em ambientes aquáticos, com predomínio da permanência do visitante em contato com a água e o leito do ecossistema;

- Banho - atividade realizada em ambientes aquáticos (rios, lagos, cachoeiras), com predomínio de nado e retorno do banhista para o exterior do ambiente aquático, com pouco ou nenhum contato com o fundo do ambiente aquático e menor tempo de permanência em relação ao balneário;

- Bote/bóia-cross - deslocamento pelo ambiente aquático com utilização desses equipamentos;

- $\quad$ Caminhada - deslocamento por trilhas com apreciação da natureza;

- $\quad$ Camping - acampamento com emprego de barracas;

- $\quad$ Cavalgada - passeio a cavalo ou boi;

- $\quad$ Visita a cavernas/grutas/dolinas - qualquer atividade desenvolvida nessas cavidades;

- $\quad$ Ciclismo - passeio com emprego de bicicletas;

- $\quad$ Flutuação - atividade de deriva sobre a superfície de ambientes aquáticos com o uso equipamentos de auxílio à flutuação como roupa de neopren, coletes salvavidas e snorkel;

- $\quad$ Hospedagem - estadia em hotéis e pousadas;

- $\quad$ Pescaria;

- Quadriciclismo - passeio com emprego de quadriciclos;

- $\quad$ Rapel - descida em rupturas de relevo com emprego de equipamentos apropriados; 
- Passeio de barco/caiaque - deslocamento pelo ambiente aquático com utilização desses equipamentos;

- $\quad$ Outros - atividades rurais não identificadas.

- Quanto aos recursos naturais explorados na execução das atividades turísticas no Planalto da Bodoquena, estes foram classificados nas seguintes categoriais:

- Rios - inclui nascentes e cursos de rios e córregos e cachoeiras (explorados por balneários, passeios de bote, caiaque e barco, bóia cross, mergulho, flutuação, banho, e pescaria);

- Lagos - lagos naturais, incluindo os inseridos em cavidades (explorados por flutuação, mergulho e contemplação);

- $\quad$ Cavidades - grutas, cavernas e dolinas (exploradas por rapel, mergulho e contemplação);

- $\quad$ Morros e tabuleiros - (explorados por rapel e trilhas em morros);

- Matas - formação vegetal natural presente principalmente em unidades de conservação, reservas legais e matas ribeirinhas, excetuando-se as localizadas em morros e tabuleiros, já incluídas na categoria anterior (explorada por trilhas ecológicas, cavalgada, arvorismo e observação da natureza);

- Outros - lagos artificiais, áreas de camping, estradas e campos rurais e recursos não identificados.

De acordo com dados obtidos junto a FUNDUR, ATRATUR, ISSQN/Bonito, SEMA/IMAP, Secretaria de Turismo de Mato Grosso do Sul e Prefeituras de Bodoquena e Bonito, foram registrados 252 empreendimentos de turismo baseados em áreas rurais no Mato Grosso do Sul. Destes, 71 estão inseridos no Planalto da Bodoquena (considerando-se os 4 municípios que possuem território nessa região: Jardim, Bonito, Bodoquena e Porto Murtinho) e o restante nas demais regiões do estado. Assim, a região do Planalto da Bodoquena abriga praticamente $1 / 3(28,5 \%)$ de todos os 
empreendimentos de turismo baseados no meio rural registrados em Mato Grosso do Sul (Figura 4).

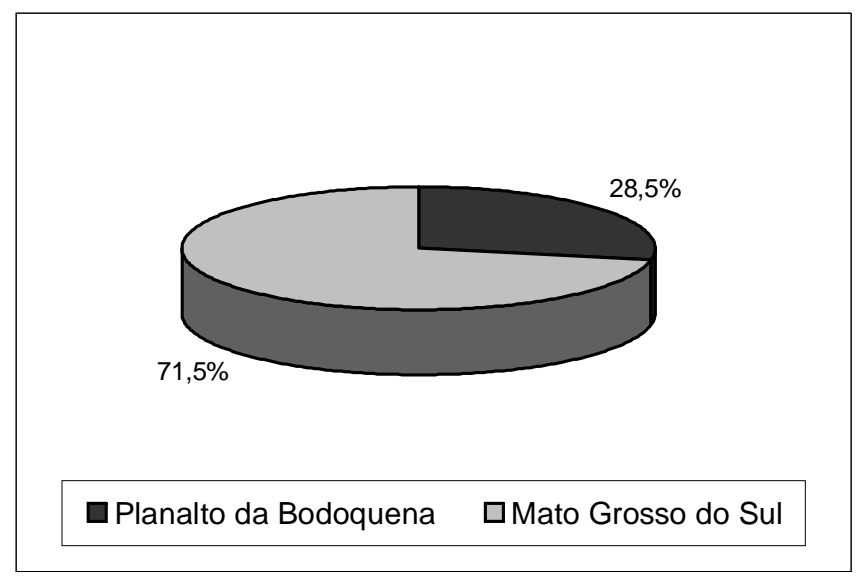

Figura 4. Importância relativa da região do Planalto da Bodoquena na distribuição dos empreendimentos de turismo baseados no meio rural e cadastrados em órgãos oficiais no Mato Grosso do Sul

Essa concentração de cerca de 1/3 de todos os empreendimentos turísticos no Planalto da Bodoquena é bastante alta, se considerarmos que essa região envolve apenas quatro municípios do estado (BOGGIANI, 1999), cujos territórios em áreas de planalto representam ao todo menos de $5 \%(4,99 \%)$ da área de Mato Grosso do Sul (IBGE, 2007). Vale ressaltar que somente uma parcela da área desses municípios referese ao Planalto da Bodoquena (BOGGIANI, op cit.) e, portanto, a real representatividade estadual da região em termos territoriais é bem menor que 4,99\%.

Dos 71 empreendimentos Inseridos no Planalto da Bodoquena, 57 (80,3\%) estão localizados no município de Bonito (Figura 5). 


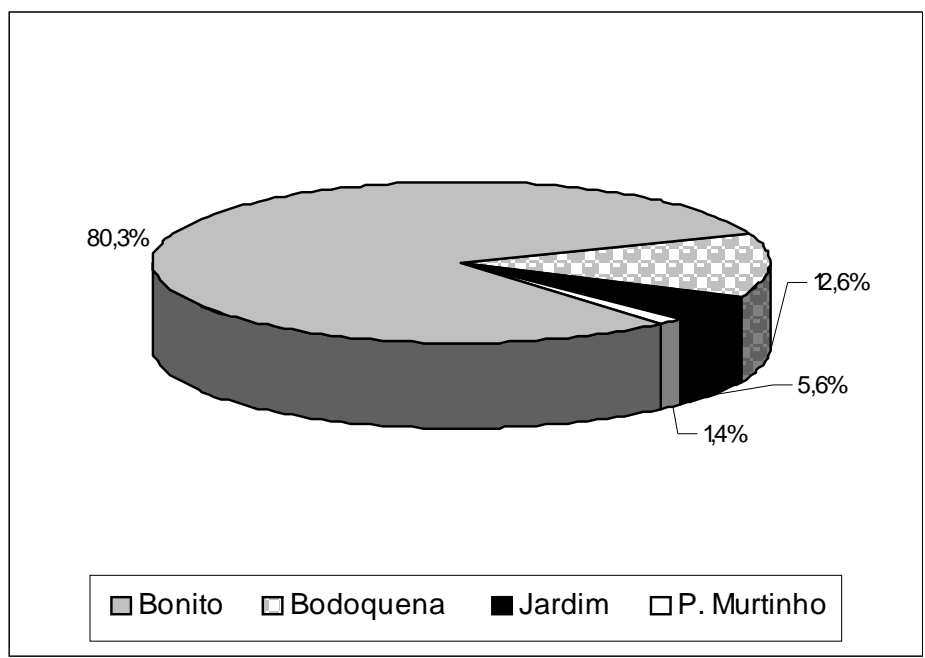

Figura 5. Distribuição relativa dos empreendimentos de turismo instalados no meio rural nos municípios do Planalto da Bodoquena.

Essa concentração de empreendimentos em Bonito pode estar relacionada ao fato do município possuir grande parte de seu território inserido no Planalto da Bodoquena e, principalmente, devido à sua projeção nacional e internacional como destino de turismo em áreas naturais, o que vem ocorrendo desde a década de 1990 (CAPELAS-Jr, 1995; RIBEIRO, 1996). A solidificação da imagem de "cidade do ecoturismo" parece atuar de forma determinante na expressiva concentração dos empreendimentos em Bonito, uma vez que o Município de Bodoquena, que não tem a mesma projeção nacional e internacional de Bonito, possui quase $100 \%$ de seu território inserido no Planalto da Bodoquena (RIO FORMOSO, 2007) e, no entanto, detém apenas $12,6 \%$ dos empreendimentos registrados na região.

Soma-se a isso também, o fato do rio Formoso, um dos principais atrativos da região, ter sua bacia hidrográfica integralmente inserida no município de Bonito, ocupando 27 \% de seu território (PCBAP, 1997). Toda a extensão do rio Formoso, de nascente a foz, está em território bonitense. De todos os empreendimentos em funcionamento registrados para o município de Bonito, praticamente 1/3 (31,6\%) estão instalados às margens do rio Formoso e o utilizam como principal atrativo natural para o desenvolvimento de suas atividades (Figura 6). 


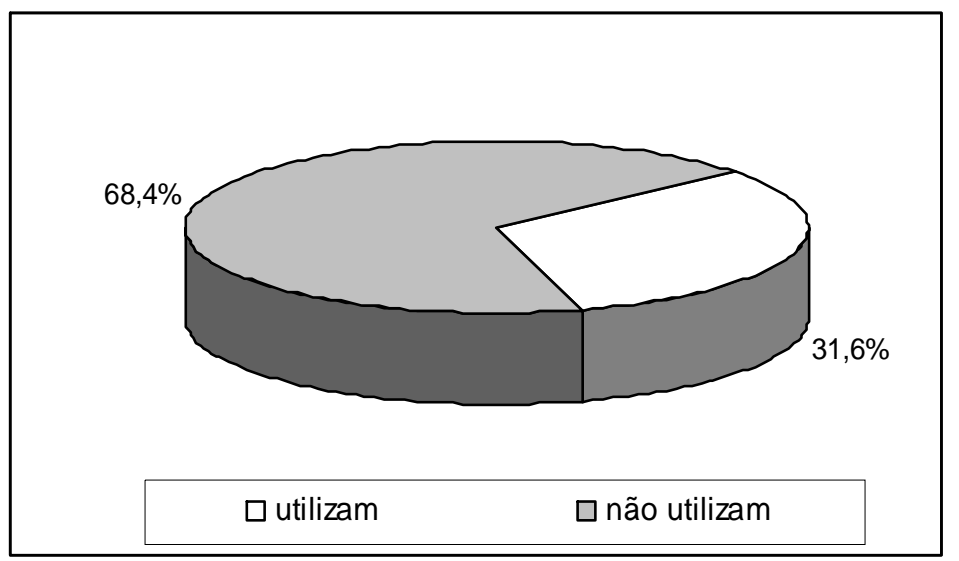

Figura 6. Proporção dos empreendimentos de turismo instalados às margens do rio Formoso em relação ao total de empreendimentos de turismo localizados no meio rural de Bonito.

Dentre as atividades turísticas desenvolvidas em empreendimentos de turismo no meio rural do Planalto da Bodoquena, as que ocorrerem com maior e menor freqüência nos empreendimentos registrados foram a caminhada e o rapel, com $54,2 \%$ e $2,8 \%$ de ocorrência, respectivamente (Figura 7).

O predomínio de caminhada pode estar relacionado à facilidade de desenvolvimento dessa atividade nos diferentes ambientes rurais, devido à praticidade de implantação e operação da mesma, inclusive permitindo a adaptação de trilhas empregadas exclusivamente como meio de acesso entre pontos para a realização da chamada caminhada ecológica, com observação de fauna, flora e apreciação da paisagem.

Já o rapel, apesar de seu potencial de desenvolvimento na região, ainda é muito pouco explorado, sendo registrado em apenas dois empreendimentos. Destes, em apenas um deles é considerado como atividade principal, enquanto no outro é desenvolvido como atividade secundária para acesso à cavidade com a finalidade de realização de mergulho e flutuação. 


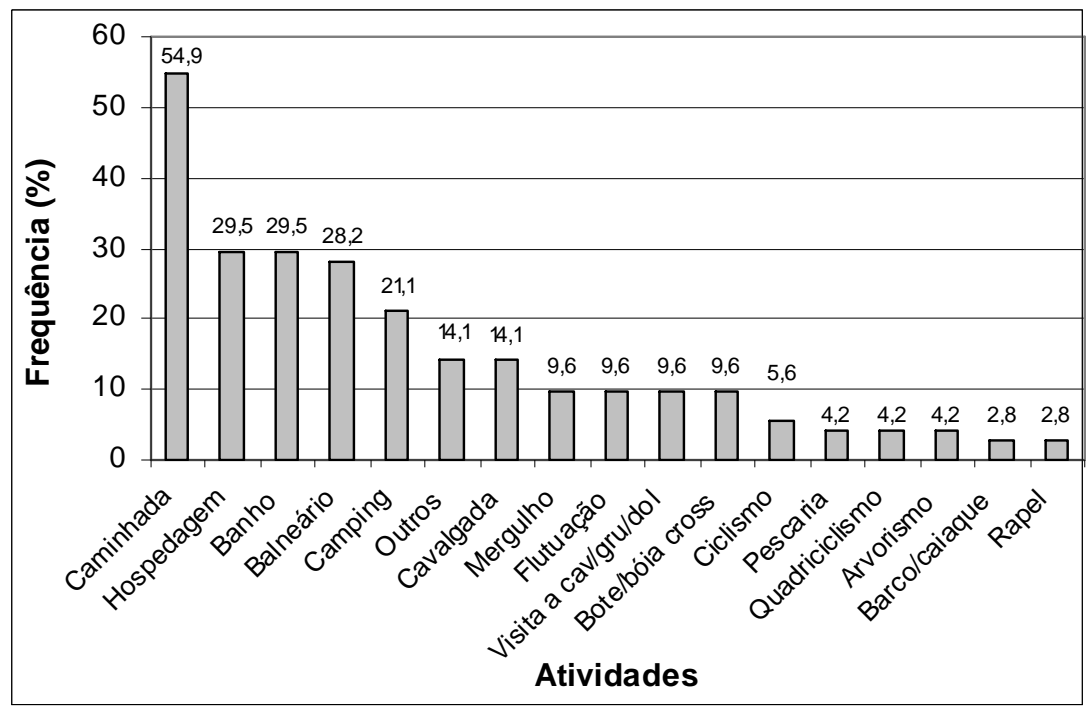

Figura 7. Freqüência de ocorrência das diferentes atividades de visitação pública nos empreendimentos turísticos desenvolvidos no meio rural do Planalto da Bodoquena

Dentre as atividades realizadas em ambientes aquáticos, banho e balneário se destacam em freqüência de ocorrência, sendo desenvolvidas em $29,2 \%$ e $27,8 \%$ dos empreendimentos, respectivamente (Figura 7). Essas atividades se destacam por estarem mais relacionadas ao chamado turismo de massa e não exigirem grande investimento em infra-estrutura para sua implantação.

No que diz respeito à demanda por atrativos naturais na região, os ecossistemas aquáticos (rios e lagos) são os que sofrem maior pressão das atividades turísticas, sendo explorados por $66,6 \%$ dos empreendimentos (Figura 8). Destes, os rios respondem pela maior demanda, sendo utilizados em 63,3\% dos empreendimentos (Figura 9). 


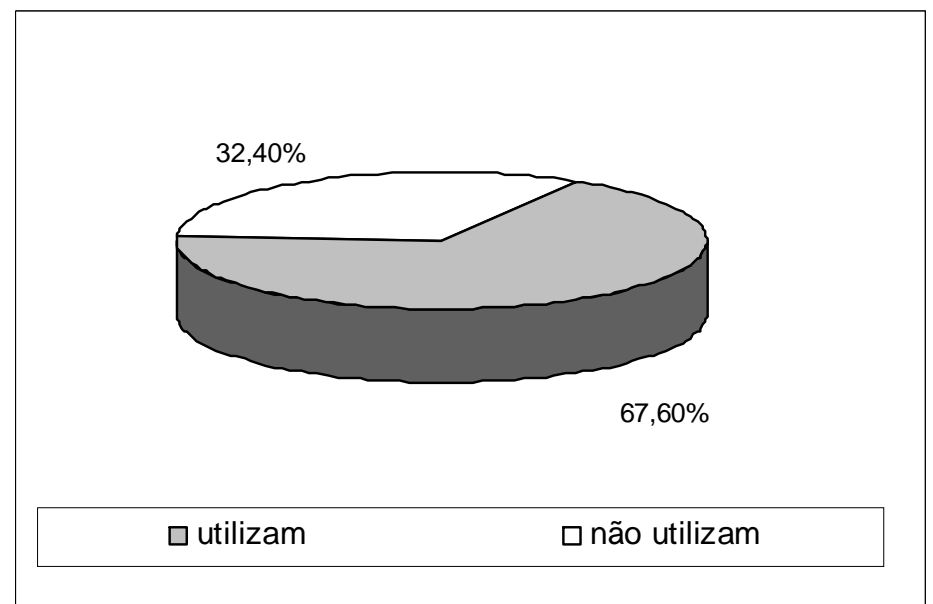

Figura 8. Utilização de ecossistemas aquáticos naturais pelos empreendimentos de turismo que exploram recursos naturais no Planalto da Bodoquena

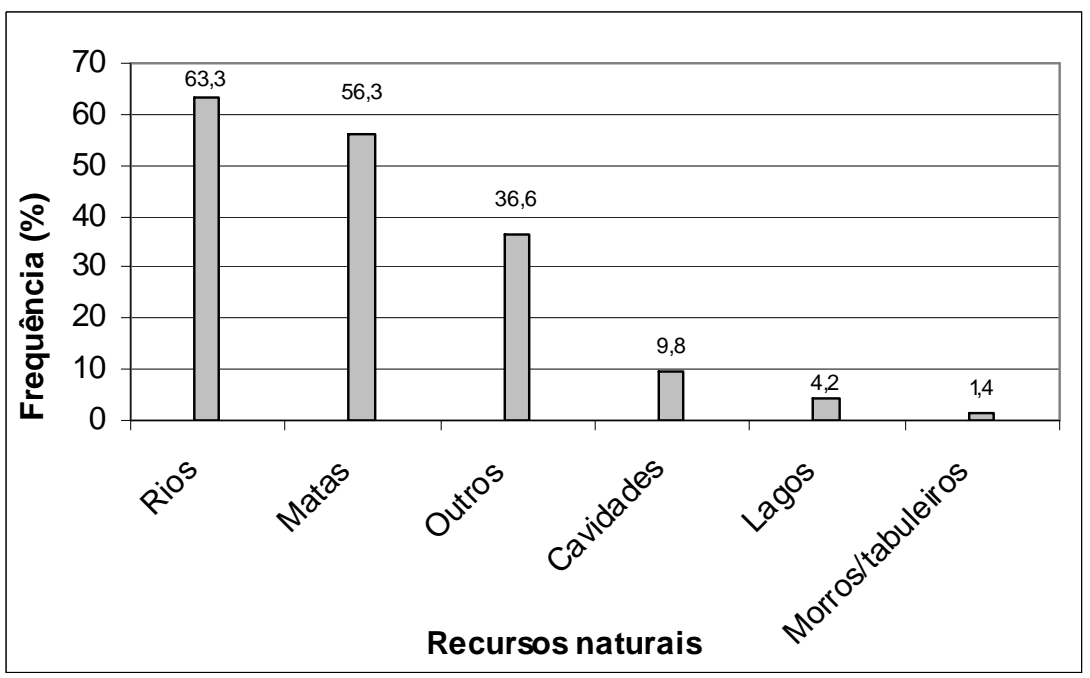

Figura 9. Demanda dos empreendimentos de turismo pelos diferentes tipos de recursos naturais no Planalto da Bodoquena

A maior freqüência de utilização dos ambientes aquáticos pelos empreendimentos turísticos reflete a preferência dos visitantes, e consequentemente dos empreendedores, por esse recurso natural, uma vez que a maioria das atividades turísticas desenvolvidas no Planalto da Bodoquena (balneário, banho, mergulho, flutuação, passeio de bote, bóiacross, caiaque, barco e pesca) está diretamente relacionada ao uso de rios e lagos. Além disso, os ambientes aquáticos representam os principais atrativos naturais no Planalto da Bodoquena devido as suas águas cristalinas, aspecto conferido pelo fato destes sistemas 
drenarem as formações calcárias predominantes na região (BOGGIANI, 1998), fenômeno detalhado na descrição da área de estudo. A alta diversidade de peixes, plantas e invertebrados aquáticos que podem ser facilmente observados nesses ambientes, como em um aquário ao ar livre, também contribuem para atrair um grande número de visitantes aos rios e lagos da região.

\subsection{Adequação das atividades turísticas ao processo de licenciamento ambiental no Planalto da Bodoquena}

Foram analisados junto a SEMA/IMAP, 14.591 processos de licenciamento ambiental relacionados a diferentes atividades e/ou empreendimentos modificadores do meio no estado de Mato Grosso do Sul, processados no período de janeiro de 2003 a dezembro de 2006. Destes, apenas 123 processos $(0,84 \%)$ referem-se a empreendimentos de turismo (Figura 10). Isso pode estar relacionado ao fato da atividade turística ainda ser incipiente no Mato Grosso do Sul, se comparada às demais atividades econômicas desenvolvidas no estado. Na análise dos processos de pedido de licenças ambientais, verificou-se que a grande maioria dos pedidos referia-se a desmatamentos para implantação de atividades agropecuárias, principais responsáveis pela economia da região.

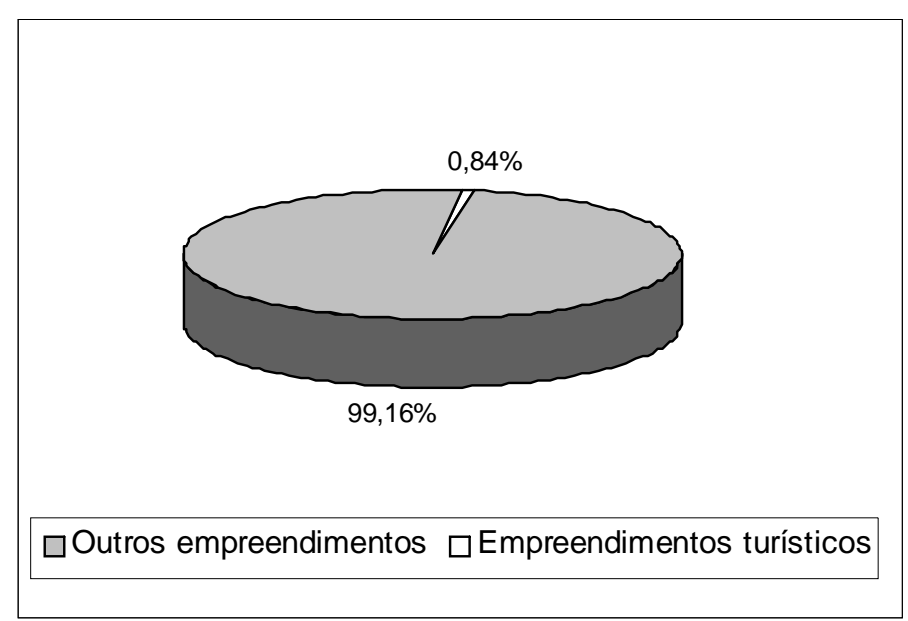


Figura 10. Participação relativa dos empreendimentos de turismo baseados no meio rural em relação ao conjunto de empreendimentos licenciados ou em licenciamento no estado de Mato Grosso do Sul

Dos empreendimentos de turismo registrados no Planalto da Bodoquena, apenas 45\% está operando com licença ambiental, enquanto 15,5\% encontra-se em processo de licenciamento e 39,5\% não apresentou registro no órgão licenciador no período considerado (Figura 11). A partir dessa constatação, podemos inferir que esses empreendimentos não cumpriram as exigências legais do processo de licenciamento e se encontram operando, desta forma, ilegalmente ou foram processados em outro período não incluído no presente estudo.

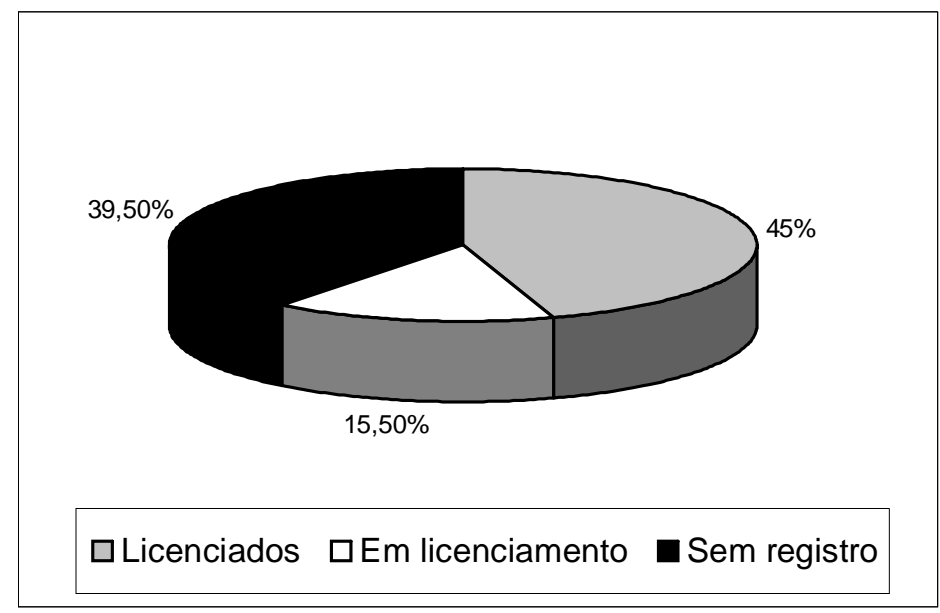

Figura 11. Proporção dos empreendimentos de turismo baseados no meio rural do Planalto da Bodoquena inseridos nas diferentes categorias do processo de licenciamento ambiental.

Dos empreendimentos que operam no rio Formoso, $68,4 \%$ estão devidamente licenciados, enquanto que $21,1 \%$ estão em fase de licenciamento e $10,5 \%$ ainda não deram entrada ao processo de licenciamento junto ao órgão ambiental competente (Figura 12). 


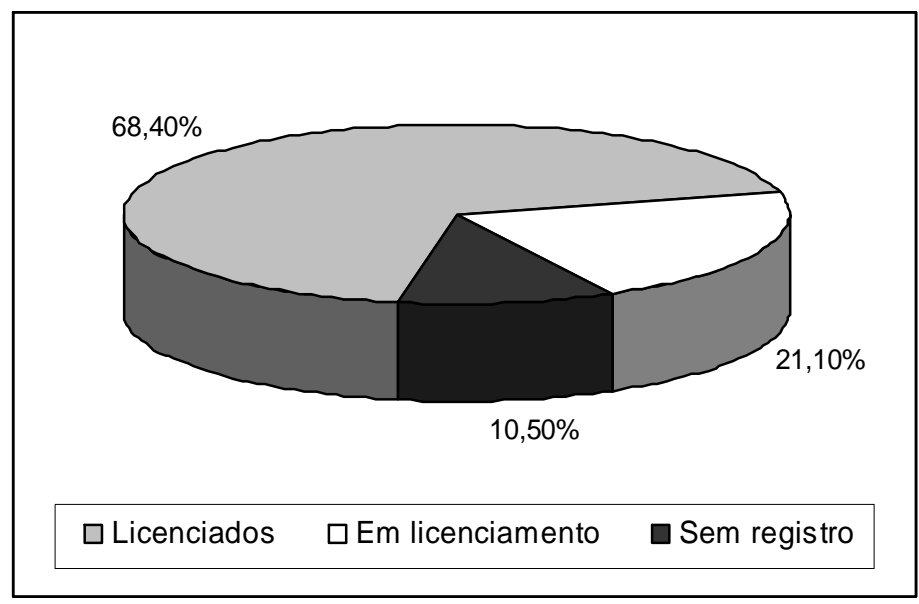

Figura 12. Proporção dos empreendimentos de turismo instalados às margens do rio Formoso inseridos nas diferentes categorias do processo de licenciamento ambiental

Considerando que as licenças ambientais fornecidas pela SEMA/IMAP aos empreendimentos turísticos raramente extrapolam quatro anos de validade, e que o presente trabalho avaliou os processos referentes a um período de exatos quatro anos, é possível assumir que a grande maioria, ou até mesmo a totalidade dos $39,5 \%$ dos empreendimentos sem registros, está operando ilegalmente no Planalto da Bodoquena, no que diz respeito ao aspecto de licenciamento ambiental. Não foi possível analisar a totalidade dos processos registrados no órgão licenciador devido à dificuldade de acesso a esses documentos, por questões burocráticas e operacionais.

Já os empreendimentos instalados às margens do rio Formoso foram objetos de estudo de caso detalhado, baseado em diagnóstico de campo, sendo possível afirmar categoricamente que o enquadramento desses empreendimentos no processo de licenciamento ambiental é o expresso na Figura 12, acima. A proporção destes empreendimentos que possuem licença ambiental $(68,4 \%)$ pode ser considerada bastante alta se comparados à situação verificada para o Planalto da Bodoquena. Isso reflete o rigor da atuação do Ministério Público Estadual nas questões ambientais do município. Através de ação judicial, em dezembro de 2005 o Ministério Público chegou a embargar os empreendimentos de turismo que estavam operando sem licença ambiental no Planalto da Bodoquena (MS NOTÍCIAS, 2006), obrigando-os a acelerarem sua 
legalização junto ao órgão Estadual de Licenciamento Ambiental. Ainda assim, 31,6\% dos empreendimentos instalados às margens do rio Formoso estão operando ilegalmente no quesito ambiental.

Os dados aqui levantados evidenciam que, apesar do apelo "ecoturístico" do Planalto da Bodoquena, o princípio fundamental da responsabilidade ambiental que é o licenciamento ambiental não recebe a devida importância nos empreendimentos turísticos instalados na região, ainda que estes se utilizem principalmente de ambientes naturais sensíveis, a exemplo da concentração de demanda sobre os ecossistemas aquáticos da região, constatada no presente estudo (Figura 8).

Swarbrooke (2000) afirma que os empreendedores do turismo obviamente querem que os clientes acreditem que o chamado ecoturismo é menos impactante e mais sustentável que o tradicional turismo de massa. Contudo, os turistas de natureza, a priori, não estão motivados a realizar viagens a ambientes frágeis por um simples desejo de proteger o meio ambiente, mas sim de contemplar aquele ecossistema natural antes dos outros. E por não ser um fenômeno de pequena escala, se ocorrer sem regulamentação, poderá facilmente se tornar tão maléfico quanto outras formas de turismo, já que os turistas de natureza, rotulados de ecoturistas, geralmente procuram sempre novos destinos, preferencialmente os mais exóticos e exclusivos do que os visitados anteriormente.

\subsection{Caracterização da estrutura para visitação e dos usos no rio Formoso}

Dos 16 empreendimentos de turismo avaliados ao longo de 15 trechos do rio Formoso, todos estavam fazendo algum tipo de uso do ambiente aquático do rio e de sua zona ribeirinha durante o período de execução do presente estudo de caso.

O banho e a caminhada se destacam como atividades mais freqüentes nos empreendimentos (Anexo 2), se assemelhando ao verificado para o Planalto da Bodoquena, onde essas atividades estão entre as 3 mais desenvolvidas (Figura 7). Ao contrário do registrado para o Planalto da Bodoquena, onde a freqüência de caminhada 
foi praticamente o dobro da verificada para o banho, nos empreendimentos localizados ao longo do rio Formoso o banho foi a mais freqüente, o que está relacionado ao fato dessas localidades favorecerem o desenvolvimentos dessa atividade.

Quanto à principal atividade desenvolvida nos empreendimentos, elas são desenvolvidas com maior freqüência no ambiente aquático (75\%), ou seja, no rio Formoso propriamente dito (Quadro 4). Apenas quando a principal atividade do empreendimento trata-se de arvorismo, hospedagem ou balneário em lago artificial é que estas não são desenvolvidas no canal do rio Formoso e sim em suas margens.

Quadro 4. Empreendimentos localizados às margens do rio Formoso e as principais atividades de visitação pública desenvolvidas

\begin{tabular}{|c|c|c|c|}
\hline \multirow{2}{*}{ Estação } & \multirow{2}{*}{ Empreendimento } & \multicolumn{2}{|c|}{ Principal atividade desenvolvida } \\
\hline & & No empreendimento & $\begin{array}{c}\text { No ambiente aquático do rio } \\
\text { Formoso }\end{array}$ \\
\hline $\bar{A}$ & $\overline{\mathbf{A}}$ & "Flutuação & "Flutuação \\
\hline B & B & Balneário em lago artificial & Passeio de barco \\
\hline \multirow{2}{*}{ C } & $\overline{C \mathbf{C 1}}$ & "Flutuação & "Flutuação \\
\hline & $\overline{C 2}$ & "Flutuação & "Flutuação \\
\hline$\overline{\mathbf{D}}$ & $\overline{\mathbf{D}}$ & Balneário & Balneário \\
\hline $\bar{E}$ & $\bar{E}$ & Bóia-crós & Bóia-crós \\
\hline $\bar{F}$ & $\bar{F}$ & Balneário & Balneário \\
\hline$\overline{\mathbf{G}}$ & $\overline{\mathbf{G}}$ & Arvorismo & "Balneário \\
\hline$\overline{\mathbf{H}}$ & $\mathbf{H}$ & Balneário & Balneário \\
\hline$\overline{I I}$ & $\overline{I I}$ & Hospedagem & Banho \\
\hline $\bar{J}$ & $\mathbf{J}$ & Bote & Bote \\
\hline 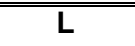 & $\overline{\mathbf{L}}$ & Bote & Bote \\
\hline$\overline{\mathbf{M}}$ & $\overline{\mathbf{M}}$ & Bote & Bote \\
\hline$\overline{\mathbf{N}}$ & $\overline{\mathbf{N}}$ & "Banho & "Banho \\
\hline 0 & 0 & Balneário & Balneário \\
\hline $\bar{P}$ & $\bar{P}$ & Hospedagem & Banho \\
\hline
\end{tabular}

Das atividades desenvolvidas como principais no ambiente aquático do rio Formoso, balneário e banho se destacam, ocorrendo ambas em $25 \%$ dos empreendimentos, enquanto o passeio de barco e bóia-cross são desenvolvidos em 
apenas $6 \%$ dos empreendimentos (Figura 11). Esses dados seguem o padrão verificado para a região do Planalto da Bodoquena (Figura 7), onde banho e balneário também se destacaram dentre as atividades desenvolvidas em ambientes aquáticos, provavelmente pela facilidade e baixo custo de implantação e manutenção.

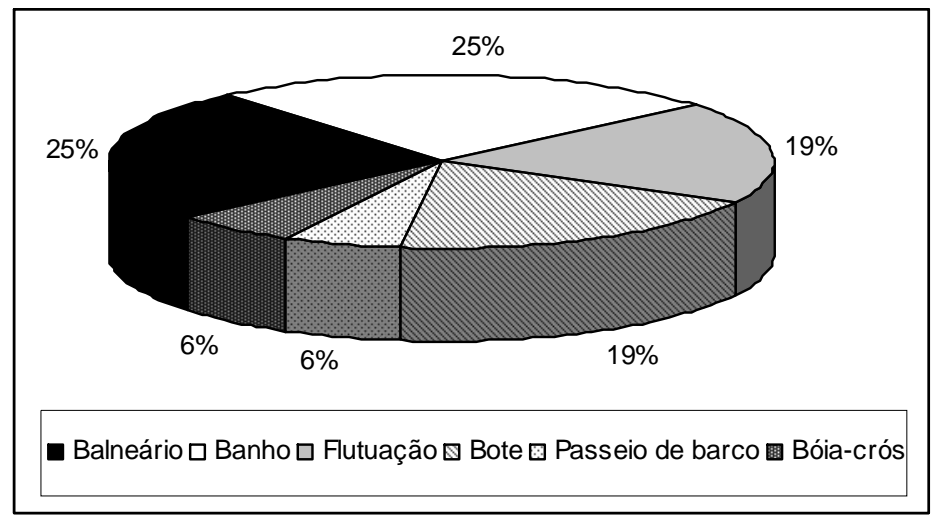

Figura 11. Participação relativa das atividades desenvolvidas como atividade principal no rio Formoso pelos empreendimentos de turismo avaliados.

De maneira geral, os empreendimentos que desenvolvem atividades de flutuação, bóia-cross e bote (C1, C2, E, J, L e M) são os que utilizam trechos de maiores extensões do rio para visitação pública (Anexo 3). A demanda de trechos longos do rio para o uso público é inerente às características dessas atividades, as quais necessitam de maiores extensões do rio para valorizar o contato do visitante com o ambiente. Os empreendimentos B e I também utilizam grandes extensões do rio, o que está associado ao desenvolvimento, de maneira secundária, de passeios de barco e caiaque, respectivamente (Anexo 2). Já o empreendimento A, mesmo tendo a flutuação como principal atividade, utiliza apenas $300 \mathrm{~m}$ do rio Formoso para a visitação pública. Isso ocorre porque a maior parte do passeio é desenvolvida no rio Sucuri, tributário do rio Formoso com cerca de $2000 m$ de extensão cuja foz está inserida na área do referido empreendimento. Assim, o passeio se inicia no rio Sucuri, a $1600 \mathrm{~m}$ da foz, e termina no rio Formoso, totalizando um percurso de cerca de $1900 \mathrm{~m}$. 
Já os balneários demandam as menores extensões do rio para uso do visitante. Por outro lado, essas atividades são as que mais concentram visitantes por trecho de rio utilizado e, consequentemente, tendem a concentrar os impactos nos trechos visitados. Esses empreendimentos também promovem grandes alterações no rio e em sua zona ribeirinha, com a implantação de estrutura para facilitar a visitação pública. Os maiores graus de ocupação da barranca (em relação à extensão total do rio utilizada - \%) e da mata ribeirinha (em relação à extensão total da zona ribeirinha ocupada - \%) estão relacionados a esses empreendimentos. A ocupação da barranca varia de $0,3 \%$, no empreendimento $M$ (passeio de bote), a $100 \%$, no empreendimento $H$ (balneário), enquanto a ocupação da mata ribeirinha considerada extremamente inadequada varia de 4,8\%, no empreendimento $\mathrm{P}$ (hotel fazenda), a 100\% no empreendimento O (balneário) (Anexo 3).

Destaca-se, ainda, a baixa capacidade dos balneários em desviar a concentração de visitantes do ambiente aquático. Isso ocorre porque esses empreendimentos se baseiam na oferta, ao visitante, do contato intenso e prolongado com o ambiente aquático e, portanto, não investem na diversificação e promoção das atividades fora do rio. Assim, mesmo quando existam no empreendimento atividades baseadas fora do ambiente aquático (Anexo 2), de maneira geral, elas são pouco atraentes ao visitante. Dentre os empreendimentos que desenvolvem o balneário, apenas o $\mathrm{G}$ exibe alta capacidade de desviar a concentração de visitantes do ambiente aquático (Anexo 3). Isso está associado ao fato da principal atividade desenvolvida nesse local estar baseada na zona ribeirinha e não no rio, o arvorismo.

\section{Caracterização da visita e dos visitantes dos empreendimentos de turismo ao longo do rio Formoso}

\subsection{Caracterização geral da visita ao longo do rio Formoso}


Desde 1995, a visita aos atrativos de turismo de Bonito é controlada pela Prefeitura Municipal, através de um sistema de voucher único (BONITO, 1995). voucher é um tipo de ingresso individual que deve ser adquirido pelos visitantes nas agências de turismo e que dá direito de acesso aos atrativos e passeios do município. É emitido às agências de turismo em blocos numerados pela Secretaria de Turismo de Bonito. Como a cada visita é emitido um novo voucher numerado e datado e como os dados são computados e plotados semanalmente, é possível se conhecer o total de visitas semanais aos atrativos do município. O intervalo semanal mantido no planilhamento dos dados deve ser levado em consideração pelo leitor na interpretação dos gráficos, uma vez que os valores plotados referem-se ao período da semana imediatamente anterior.

A partir desse controle, verifica-se que a visitação aos atrativos de turismo de Bonito se distribui de maneira bastante irregular ao longo do ano (Figura 12), se concentrando principalmente nos períodos de férias e feriados prolongados, o que pode ser visualizado com maior clareza quando se analisa os dados de apenas um ano, como exemplificado na Figura 13. Esse padrão de distribuição temporal da visitação é comum em regiões e cidades reconhecidas como destinos turísticos, a exemplo do que ocorre em outras áreas naturais visitadas do Brasil (TAKAHASHI, 1998, ROBIM 1999, SCHIAVETTI, 2003) e do exterior (JIM, 1989, OSEMEOBO, 1989). 


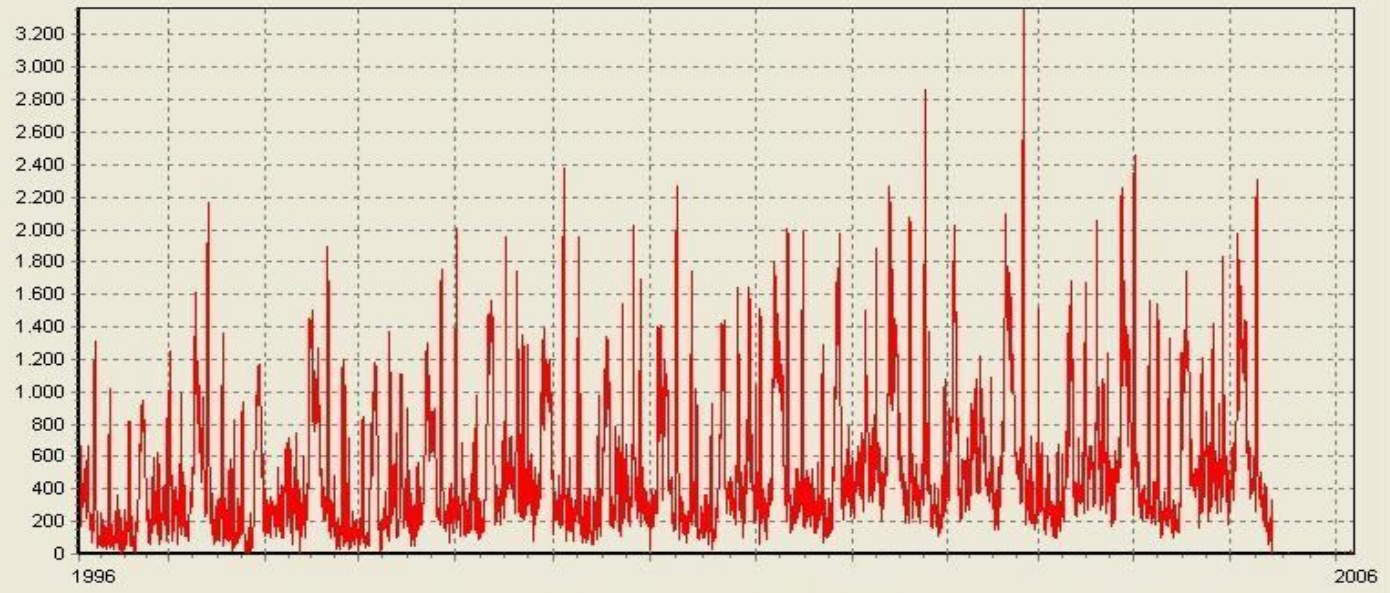

Figura 12. Evolução das visitas semanais aos empreendimentos de turismo no município de Bonito no período de 1996 a 2006 (Fonte: ISSQN/Bonito, MS).

Em Bonito, nos feriados prolongados a visitação diária é ainda mais concentrada quando comparada ao período de férias. Isso se deve ao menor número de dias disponíveis para o visitante realizar suas atividades de lazer, levando à ocorrência de picos de visitas aos atrativos em intervalos de 2 a 4 dias. Esse comportamento sazonal da visitação traz importantes implicações ao manejo das áreas naturais visitadas, uma vez que os impactos tendem a se concentrar sobre os componentes bióticos e abióticos do meio durante as temporadas. Assim, podemos assumir que os sistemas ambientais visitados sofrem com efeitos "agudos" e "crônicos" da visitação pública, relacionados aos impactos concentrados nos picos de temporada e aqueles provocados pela visitação distribuída ao longo do ano, respectivamente. Essas diferenças não podem ser negligenciadas em programas que visem conhecer e manejar os efeitos da visitação pública sobre os ambientes naturais da região. 


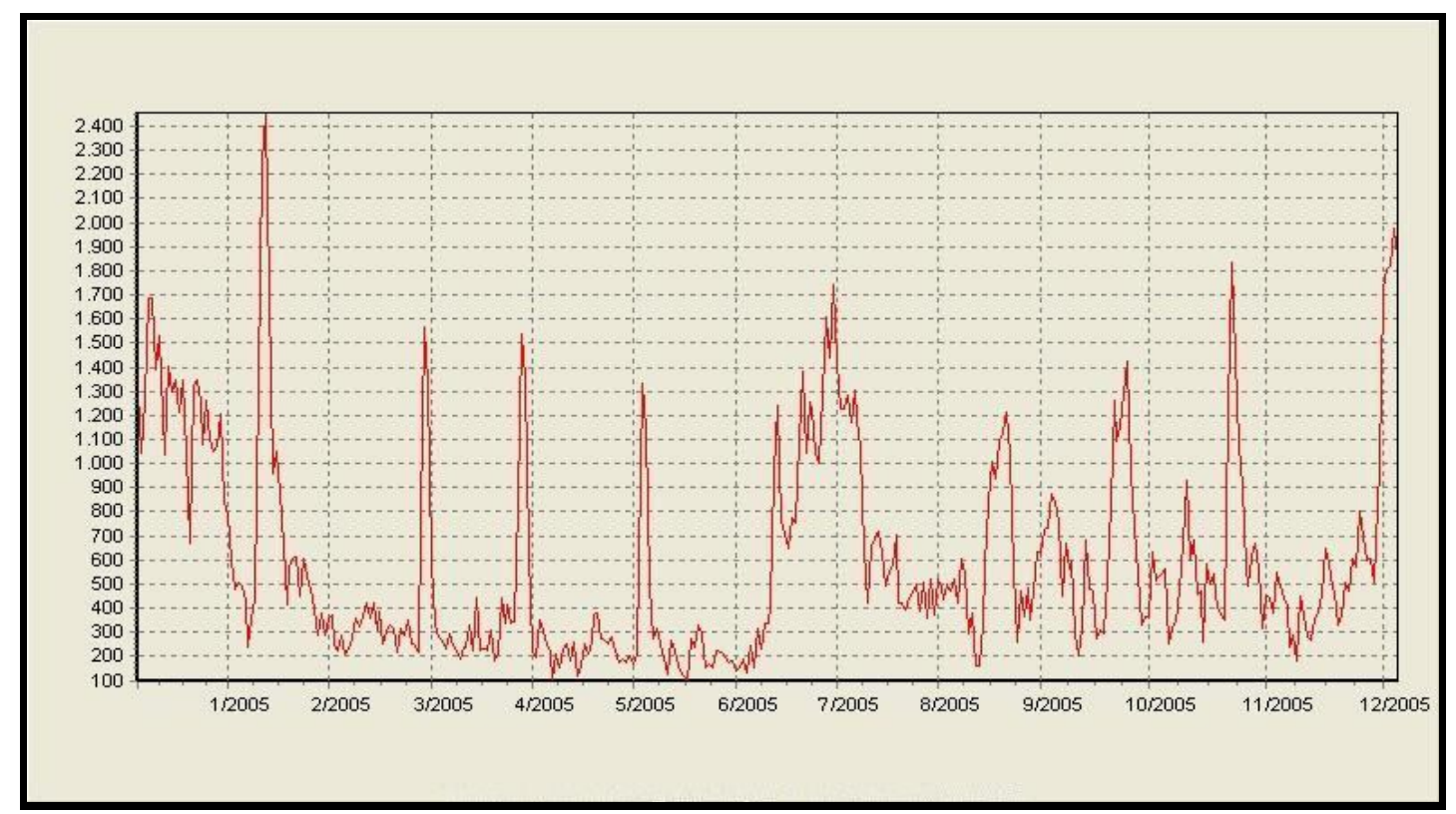

Figura 13. Evolução das visitas semanais aos empreendimentos de turismo no município de Bonito no ano de 2005 (Fonte: ISSQN/Bonito, MS).

Foi entrevistado um total de 364 visitantes do rio Formoso no período de carnaval (25 a 28/02/06), o que permitiu traçarmos as características da visitação e dos visitantes que elegeram esse atrativo natural como destino durante o referido feriado.

Dos entrevistados, 38,1\% estavam visitando Bonito pela primeira vez e 51,4\% disseram retornar pelo menos 3 vezes ao ano (Figura 14), sendo que 53,6\% pretendiam permanecer no município por até 7 dias (Figura 15) e 45,3\% viajavam em grupos de 2 a 4 pessoas (Figura 16). A alta freqüência de retorno ao município, aliada a uma permanência prolongada dos visitantes na localidade, pode ser explicada pela procedência destes, uma vez que a grande maioria dos respondentes é proveniente de localidades próximas, no próprio estado (63,1\%), com destaque para Campo Grande, onde residiam $29,9 \%$ dos entrevistados, enquanto apenas $1,4 \%$ era formado por bonitenses. Dos demais, $35,2 \%$ residiam em outros estados, dos quais os paulistas e paranaenses representavam, $19,5 \%$ e $7,4 \%$, respectivamente, e apenas $1,7 \%$ eram procedentes do exterior (Figura 17).

Ficou evidente a baixa procura dos munícipes pelos atrativos de Bonito, ao menos durante a alta temporada, o que serve como parâmetro para alertar o poder público da 
necessidade de se implementar políticas que promovam um maior envolvimento da população local com o uso público das áreas naturais. Por outro lado, predominou um alto índice de visitantes provindos de outros municípios sul-matogrossenses. Como Mato Grosso do Sul não possui tradição em festas de carnaval, é comum que nesse feriado as pessoas busquem localidades onde possam desenvolver atividades de veraneio, cenário em que Bonito se destaca atraindo um grande número de pessoas de municípios próximos. Takahashi (1987) também verificou que a maioria dos visitantes que freqüentavam áreas de recreação ao ar livre, ao longo da Estrada da Graciosa/PR, residia em localidades próximas.

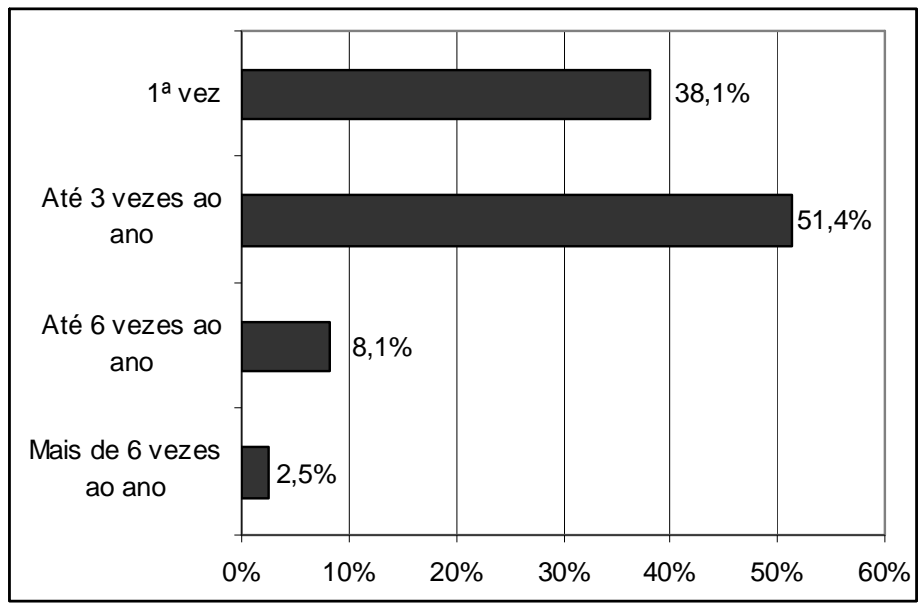

Figura 14. Freqüência com que os entrevistados visitam Bonito.

A grande maioria dos entrevistados $(78,4 \%)$ apontou algum tipo de atividade na água como a principal desenvolvida por eles durante a visita a Bonito, com destaque para nadar e tomar banho, com $36 \%$ de preferência, enquanto praticar esportes fora d'água foi apontada como preferida por apenas $0,3 \%$ dos visitantes (Figura 18). A preferência dos visitantes por atividades relacionadas ao meio aquático já era esperada, tendo em vista a demanda já constatada para esses ambientes no Planalto da Bodoquena. Soma-se a isso o fato da pesquisa ter sido realizada integralmente em empreendimentos situados às margens de um dos ecossistemas aquáticos mais visitados da região, o rio Formoso. A 
preferência atribuída a nadar e tomar banho pode estar relacionada ao fato da maioria dos visitantes se concentrar em balneários, aliada ao menor custo dessa atividade frente às demais opções.

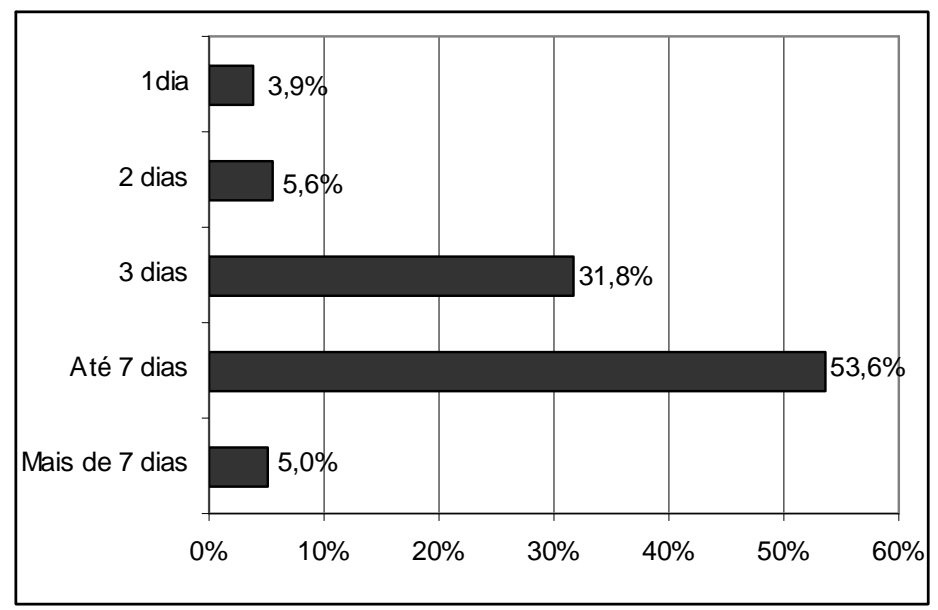

Figura 15. Tempo de permanência dos visitantes entrevistados em Bonito.

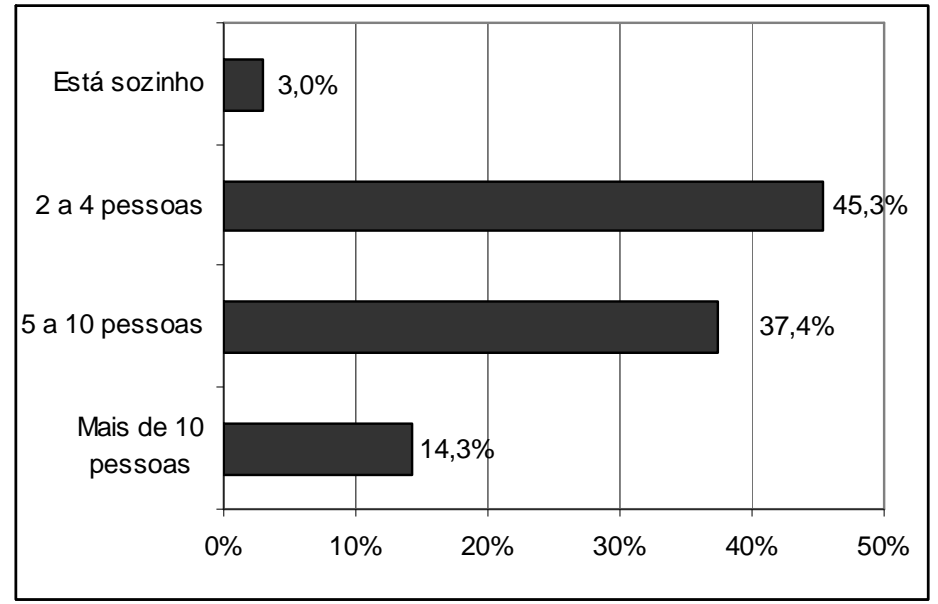

Figura 16. Distribuição dos visitantes entrevistados por tamanho de grupo de viagem. 


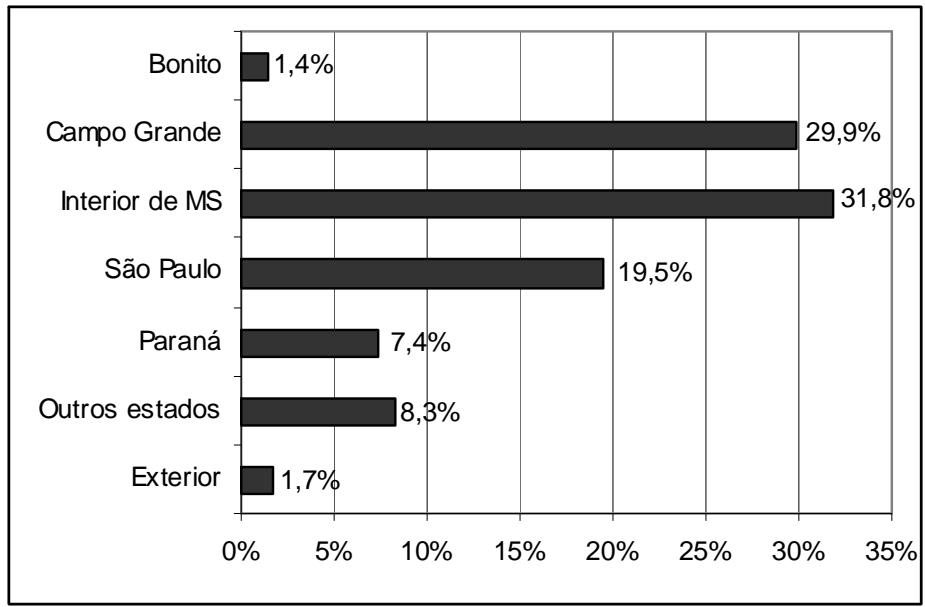

Figura 17. Procedência dos visitantes entrevistados.

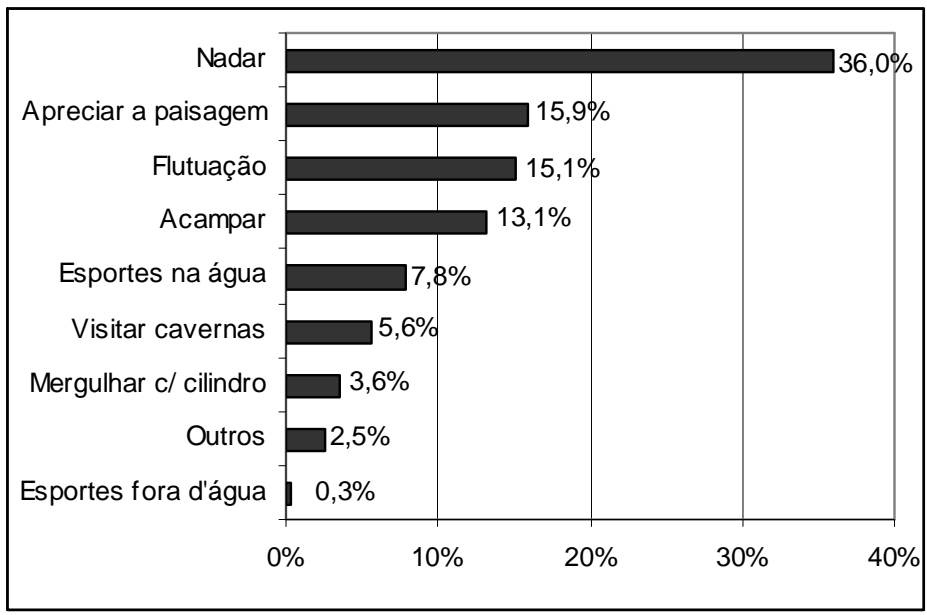

Figura 18. Principais atividades desenvolvidas pelos visitantes durante visita a Bonito.

Quanto às características dos visitantes, houve participação praticamente eqüitativa dos dois gêneros dentre os entrevistados (Figura 19), sendo que a grande maioria (50,4\%) possui de 20 a 30 anos (Figura 20), 64\% está ao menos cursando o ensino superior (Figura 21), 52,4 \% possui renda mensal de no mínimo $R \$ 2000,00$ e apenas 2,2\% ganha menos de $\mathrm{R} \$ 500,00$ ao mês (Figura 22). 


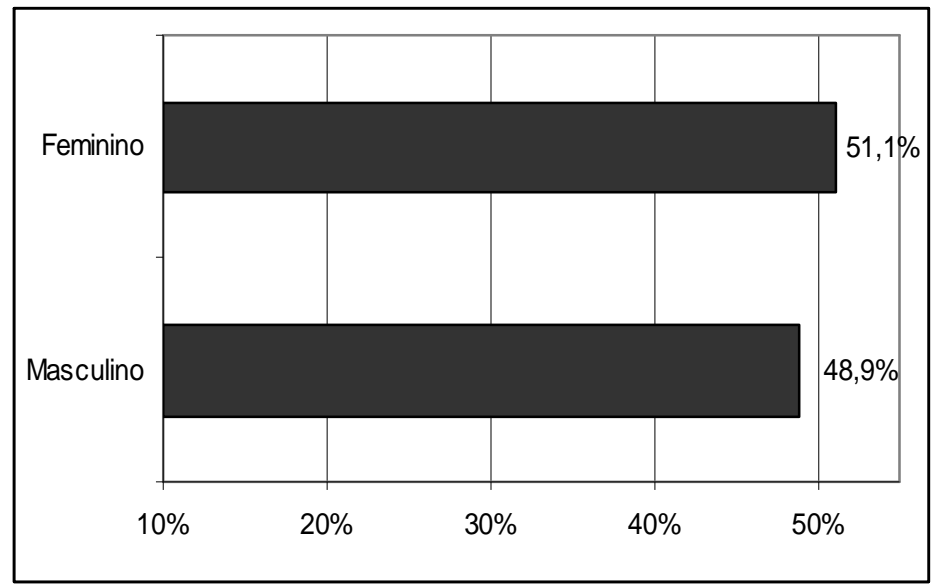

Figura 19. Distribuição dos visitantes entrevistados por gênero

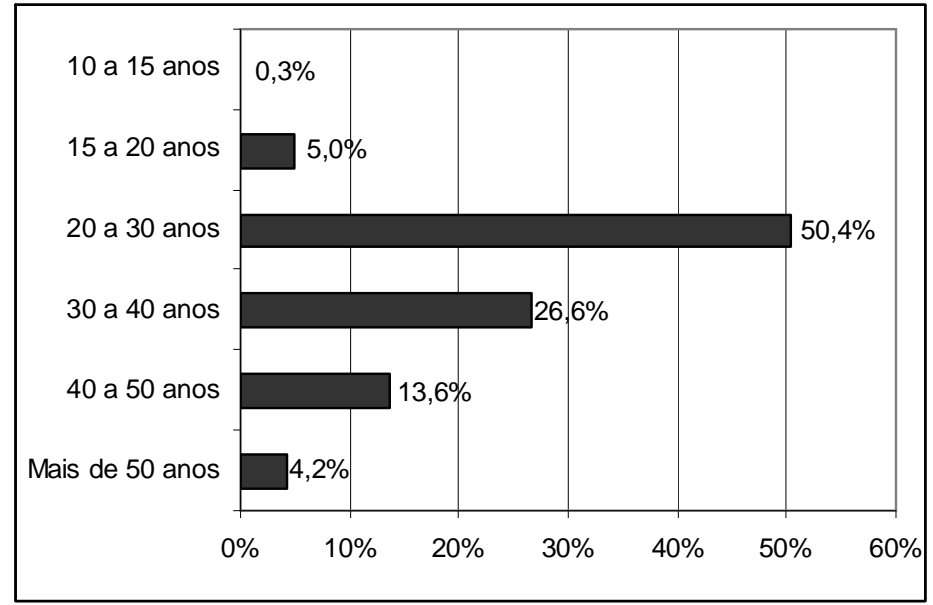

Figura 20. Faixa etária dos visitantes entrevistados

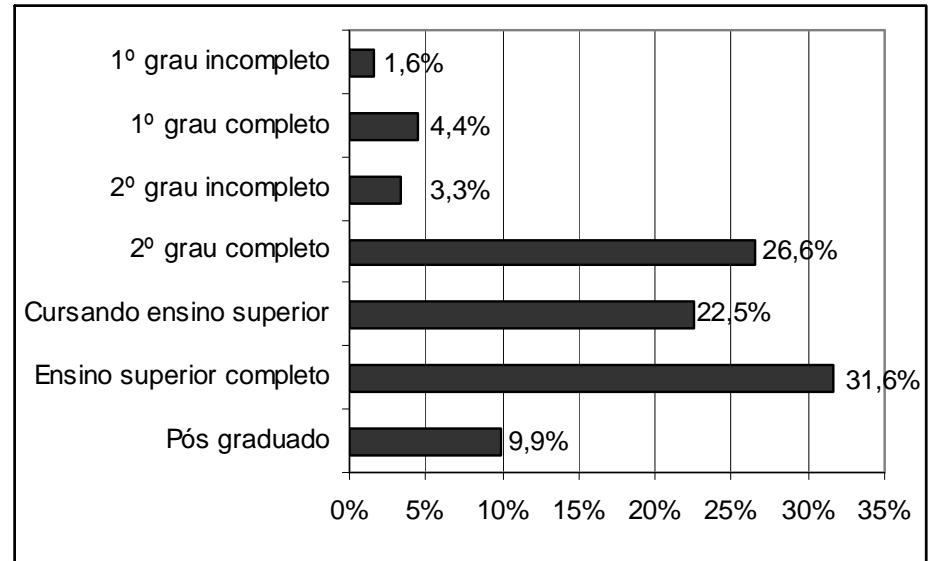

Figura 21. Grau de escolaridade dos visitantes entrevistados 


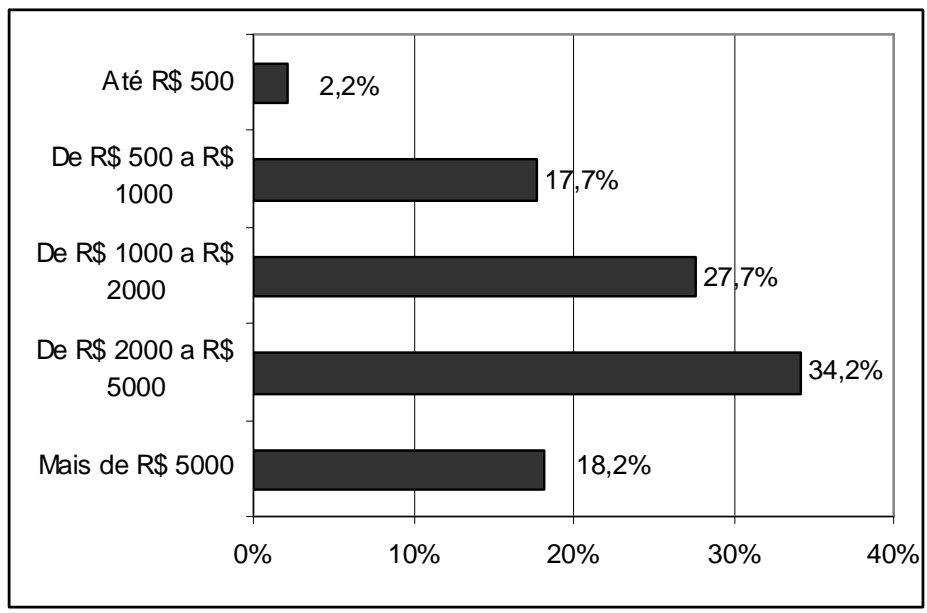

Figura 22. Faixa de renda familiar dos visitantes entrevistados

A partir dos descritores de perfil obtidos para os visitantes, pode-se verificar que estes são, na sua maioria, jovens de classe média, com bom nível de escolaridade e que se organizam em grupos mistos de homens e mulheres para viajar. Esse perfil reflete a busca dos jovens de bom poder aquisitivo, que consequentemente apresentam bom nível de escolaridade, por atividades em área naturais fora de sua cidade de origem nos períodos de feriados prolongados. Situação semelhante foi verificada em outras áreas naturais estudadas em períodos de feriados (TAKAHASHI, 1987, BONTEMPO, 1994; TAKAHASHI, 1998, ROBIM, 1999).

\subsection{Características da visita, características e percepção ambiental dos visitantes e sua relação com os empreendimentos estudados}

Através do cruzamento das informações sobre as características da visita e dos visitantes com os locais estudados, verifica-se que grande parte dos empreendimentos estava sendo visitada pela primeira vez, pela maioria dos entrevistados (Anexo 4.1). Entretanto, nos empreendimentos que desenvolvem o balneário como principal atividade, a maioria dos visitantes afirmou visitar o local toda vez que vem à Bonito. Isso destaca a preferência dos visitantes por esta atividade, com a conseqüente concentração dos impactos nestes locais. Como já discutido, provavelmente isso está relacionado ao baixo 
custo de acesso e permanência nestes locais, os quais concentram o maior número de visitantes com menor renda dentre os entrevistados (Anexo 4.7). O fato dos balneários apresentarem, via de regra, pouca ou nenhuma restrição à utilização dos recursos naturais durante a visita também pode ser um fator determinante no retorno do visitante a estes locais no período de carnaval e, provavelmente, em outros feriados. Todos os balneários apresentaram elevado número de visitantes que consideram a atividade nadar como a principal desenvolvida por eles durante a visita.

Os balneários concentraram a maioria de visitantes com menos de trinta anos, menor escolaridade (não possui ensino superior) e organizados em grupos de mais de cinco pessoas. A alta concentração de visitantes jovens com menor escolaridade, bem como de grandes grupos nestes locais, pode estar contribuindo com a maior ocorrência de impactos ambientais sobre os ambientes naturais visitados, uma vez que visitantes com esse perfil tendem a ser mais ativos e apresentarem interação mais intensa com o meio.

O tempo de permanência dos visitantes em cada local também esteve relacionado à principal atividade desenvolvida pelos empreendimentos. Nos locais onde as atividades demandam menos tempo para serem executadas como flutuação e bóia-cross, a maioria dos visitantes permanecem até meio dia, enquanto que nos locais que oferecem estadia (hotéis fazenda e camping), a permanência predominante é de três a sete dias. Já nos balneários a maioria dos visitantes afirmou permanecer o dia todo (Anexo 4.2). A curta duração da visita nos empreendimentos de flutuação e bóia-cross pode contribuir para dispersar o impacto nesses locais.

Os visitantes com menor grau de exigência ambiental quanto aos impactos decorrentes da visitação pública no meio são, principalmente, aqueles que freqüentam os balneários, com exigência ambiental baixa ou média (Anexo 5.10 e Figura 23). Um empreendimento que desenvolve principalmente bóia-cross (empreendimento $M$ ) e outro no qual a principal atividade é o banho (empreendimento $\mathrm{N}$ ) também apresentaram visitantes cujo grau de exigência ambiental é apenas médio. Saltar no rio foi a 
interferência menos percebida pelos entrevistados em geral, para o qual foi verificado baixo grau de exigência ambiental dos visitantes em praticamente todos os empreendimentos. Tocar o fundo do rio com os pés e subir ou deslizar sobre as tufas calcárias tiveram baixa importância para os entrevistados de todos os balneários. Pisar sobre pequenas plantas na margem e promover o som alto também tiveram baixa importância em quase a totalidade dos balneários.

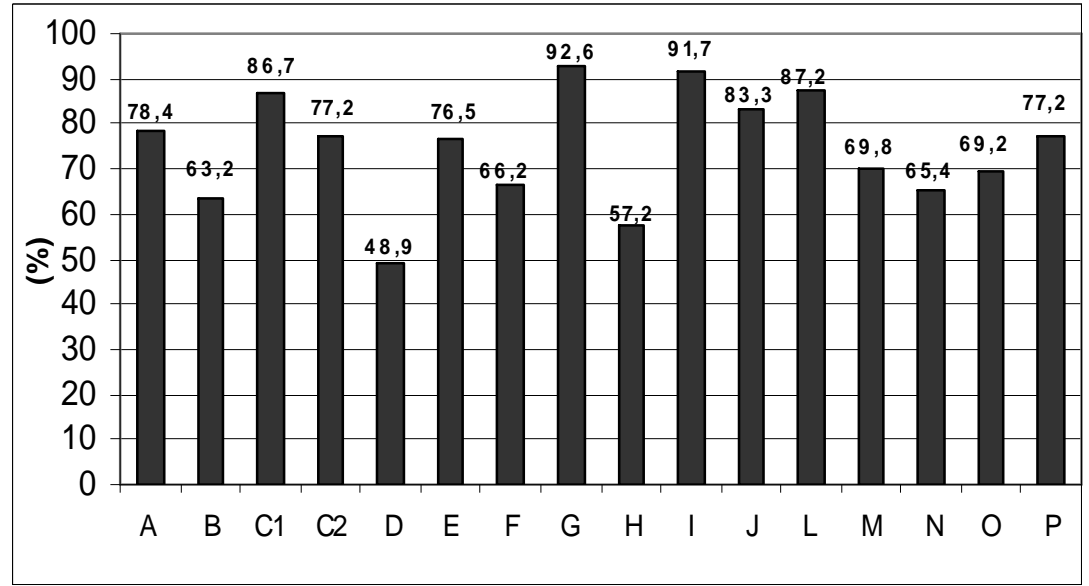

Figura 23. Grau de exigência ambiental dos visitantes (\%) em relação aos impactos provocados pela visitação pública no rio Formoso ao longo dos empreendimentos estudados

Para o comportamento de deixar o lixo fora da lixeira, a exigência ambiental dos visitantes foi bastante elevada em todos os empreendimentos, se enquadrando como muito alta em praticamente todos os locais. Apenas no empreendimento $D$ (balneário) a exigência ambiental dos visitantes foi considerada menor que nos demais locais, mesmo assim se enquadrando na categoria Alta exigência (Anexos 5.10),o que pode ter contribuído com a reduzida concentração de resíduos sólidos nos empreendimentos avaliados ao longo do rio Formoso (Tabela 10), evidenciando uma possível relação entre o perfil e a percepção ambiental do visitante e o tipo e grau de impacto ambiental impresso nas áreas visitadas.

Os empreendimentos cujos visitantes exibiram o maior grau de exigência ambiental têm suas principais atividades de visitação baseadas fora do ambiente 
aquático (Anexo 5.10). Os impactos sobre tufas calcárias foram os menos tolerados pelos visitantes desses locais.

\section{Caracterização dos impactos ambientais do uso público no rio Formoso através do emprego de variáveis físicas e biológicas}

\subsection{Condições abióticas da água e do sedimento}

Os resultados das variáveis abióticas descritoras das condições da água e do sedimento encontram-se sumariados nos Anexos 6 e 7, respectivamente.

No caso das condições da água, as variáveis de maior peso foram fósforo total ( $\mathrm{P}$ total) e transparência da água ( $F 1-84,3 \%$ de explicação) e condutividade elétrica e concentração de sólidos suspensos (F2 - 14,98\% de explicação) para o grupo de balneários; P total e condutividade elétrica (F1 - 76,36\% de explicação e F2 - 18,98\% de explicação) para o grupo de passeios de barco, bote e bóia-cross; condutividade elétrica e transparência da água ( $F 1$ - 81,42\% de explicação) e P total e transparência da água (F2 - 16,54\% de explicação) para o grupo de banho e flutuação (Tabela 1). No gráfico de ordenação dessas variáveis e estações de amostragem, não ficaram evidentes diferenças entre os pontos de impacto e controle em nenhum dos grupos de estações analisados (Figuras 24, 26 e 28). Todavia, ocorreram distinções entre as estações de amostragem, evidenciando alterações espaciais ao longo do rio no valor das variáveis medidas. A ordenação espacial foi mais marcante para os grupos de balneários e banho e flutuação.

Para as condições abióticas do sedimento, textura granulométrica fina e folhedo foram as variáveis com maior peso (F1 e F2) para todos os grupos de estações (Tabela 
2). Os eixos F1 e F2 explicaram respectivamente $97,97 \%$ e $1,98 \%$, no grupo de balneários; $71,92 \%$ e 25,36\%, no grupo de passeios de barco, bote e bóia-cross e $57,63 \%$ e $41,14 \%$ no grupo de banho e flutuação. Essas variáveis também atuaram distinguindo os pontos de impacto dos pontos controle em todos os grupos, conforme verificado na ordenação dos dados (Figuras 25, 27 e 29). Entretanto, essa distinção ficou pouco evidente para a estação E, no grupo de passeio de barco, bote e bóia-cross e para as estações $\mathrm{A}$ e N, no grupo de banho e flutuação.

Quanto à regularidade na diferença dos valores das variáveis abióticas descritoras das condições da água e do sedimento nos pontos de impacto em relação aos respectivos pontos controle, profundidade e transparência da água variaram negativamente e sólidos suspensos variaram positivamente em $100 \%$ das estações de balneários. No grupo de passeios de barco, bote e bóia-cross, nenhuma variável exibiu regularidade de variação, enquanto no grupo de banho e flutuação, apenas profundidade variou regularmente (negativamente) em 100\% das estações (Tabela 3).

Dentre as variáveis do sedimento, $100 \%$ das estações de balneário exibiram variação regular (negativamente) para todas as variáveis medidas. A concentração de folhedo também variou negativamente em $80 \%$ das estações de amostragem, tanto para o grupo de passeios de barco, bote e bóia-cross quanto para o grupo de banho e flutuação (Tabela 4). 


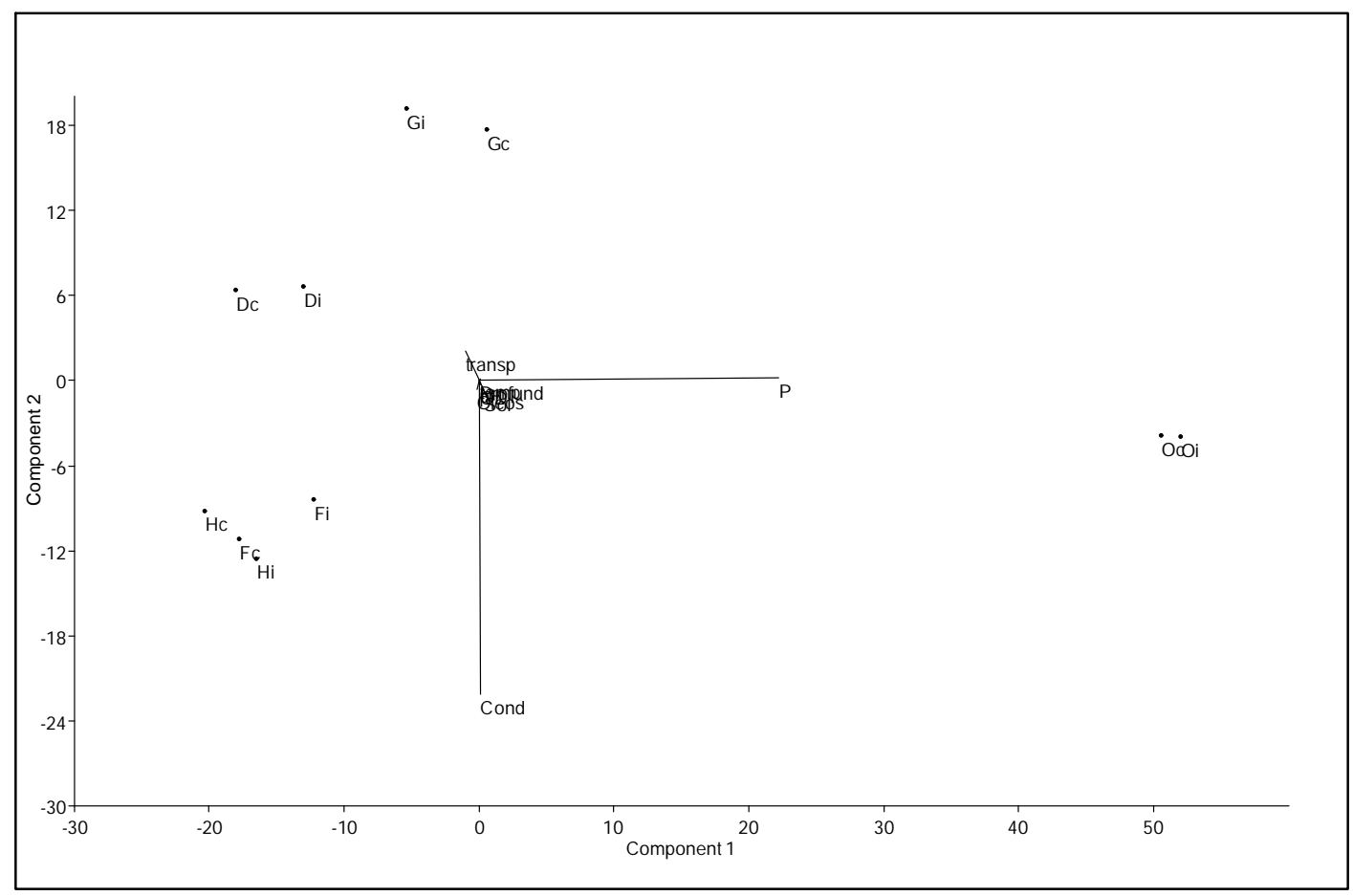

Figura 24. Ordenação através da Análise de Componentes Principais (PCA) das variáveis descritoras das condições abióticas da água no grupo de balneários

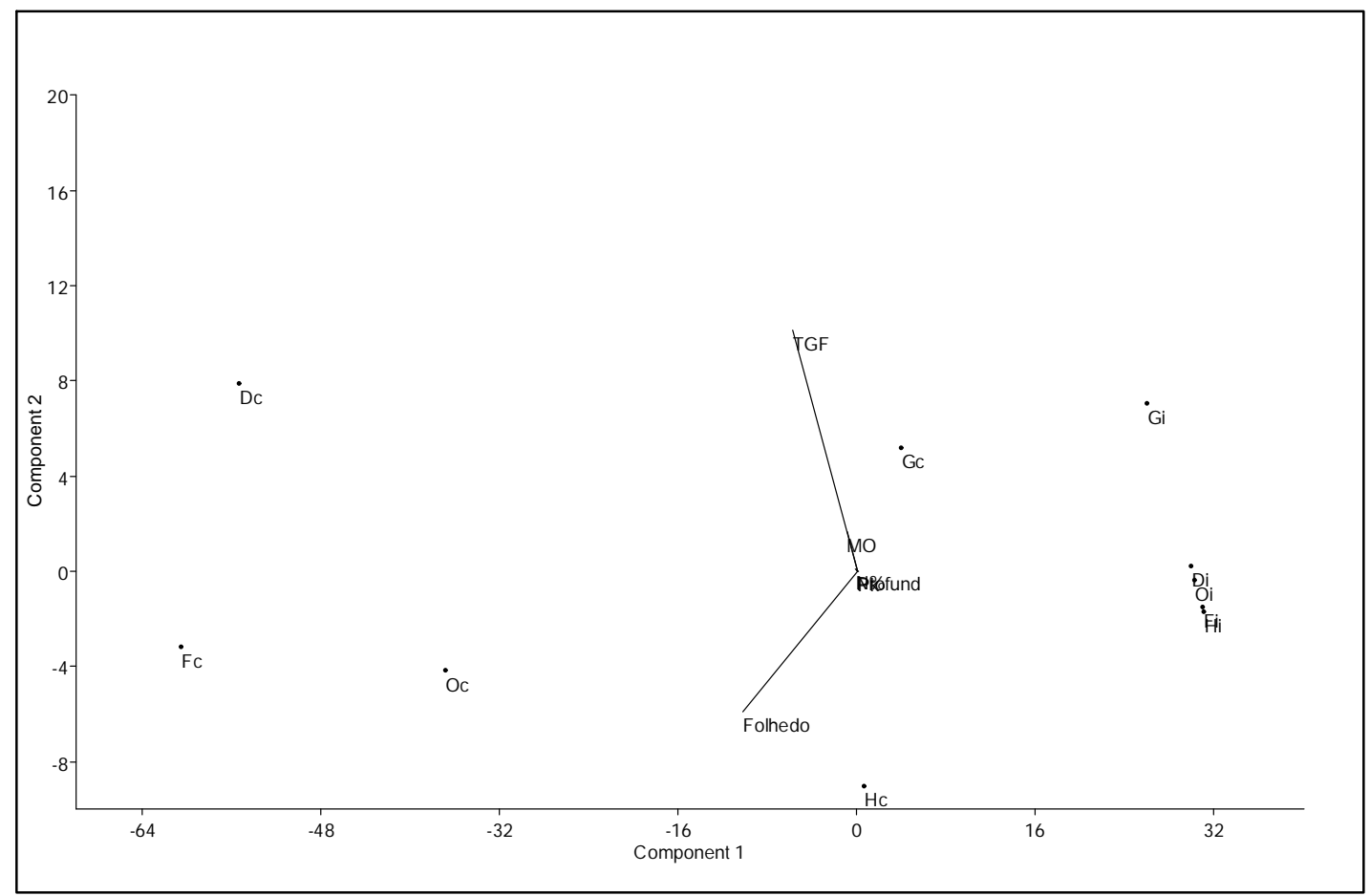

Figura 25. Ordenação através da Análise de Componentes Principais (PCA) das variáveis descritoras das condições abióticas do sedimento no grupo de balneários. 


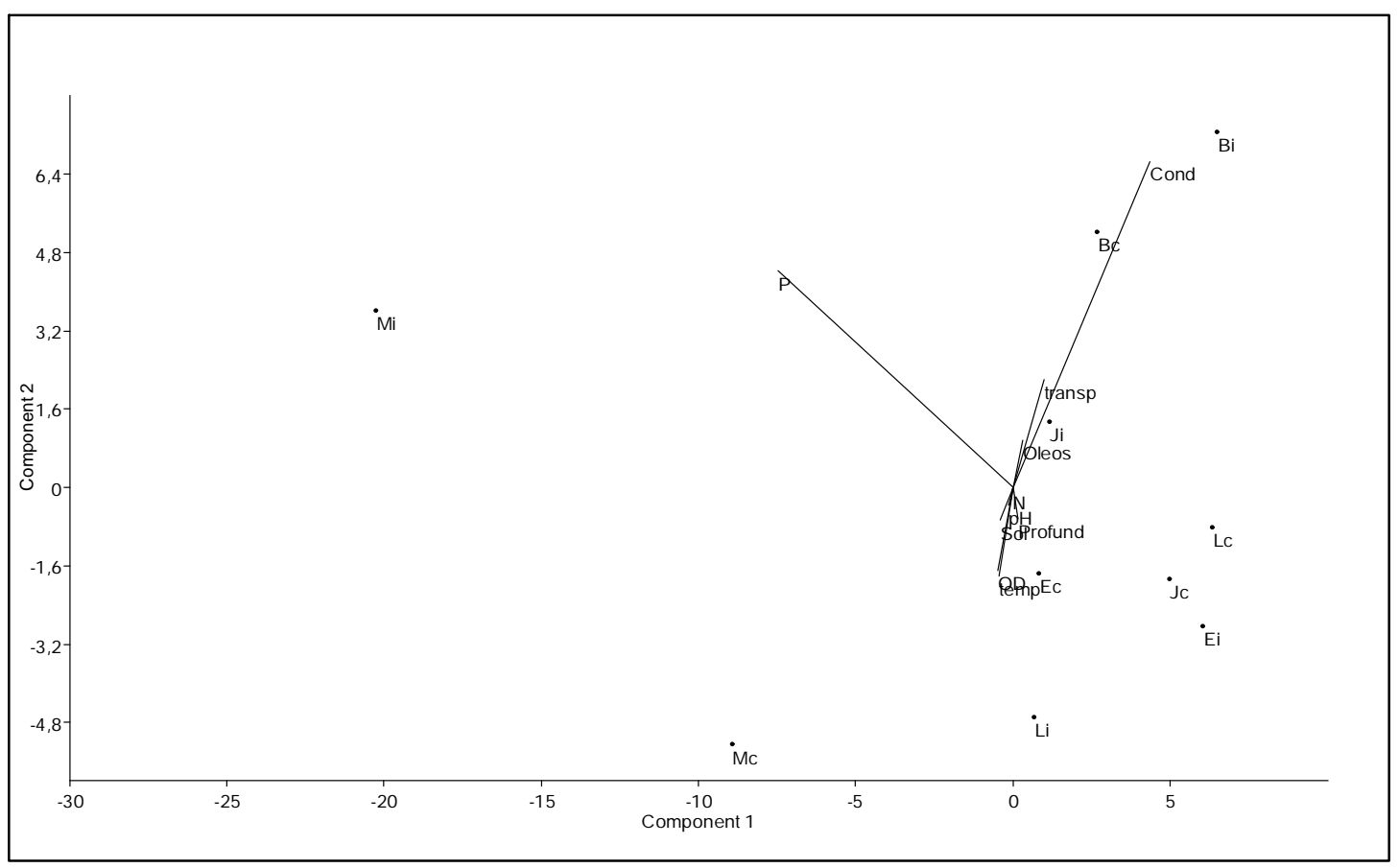

Figura 26. Ordenação através da Análise de Componentes Principais (PCA) das variáveis descritoras das condições abióticas da água no grupo de empreendimentos de passeio de barco, bote e bóia-cross.

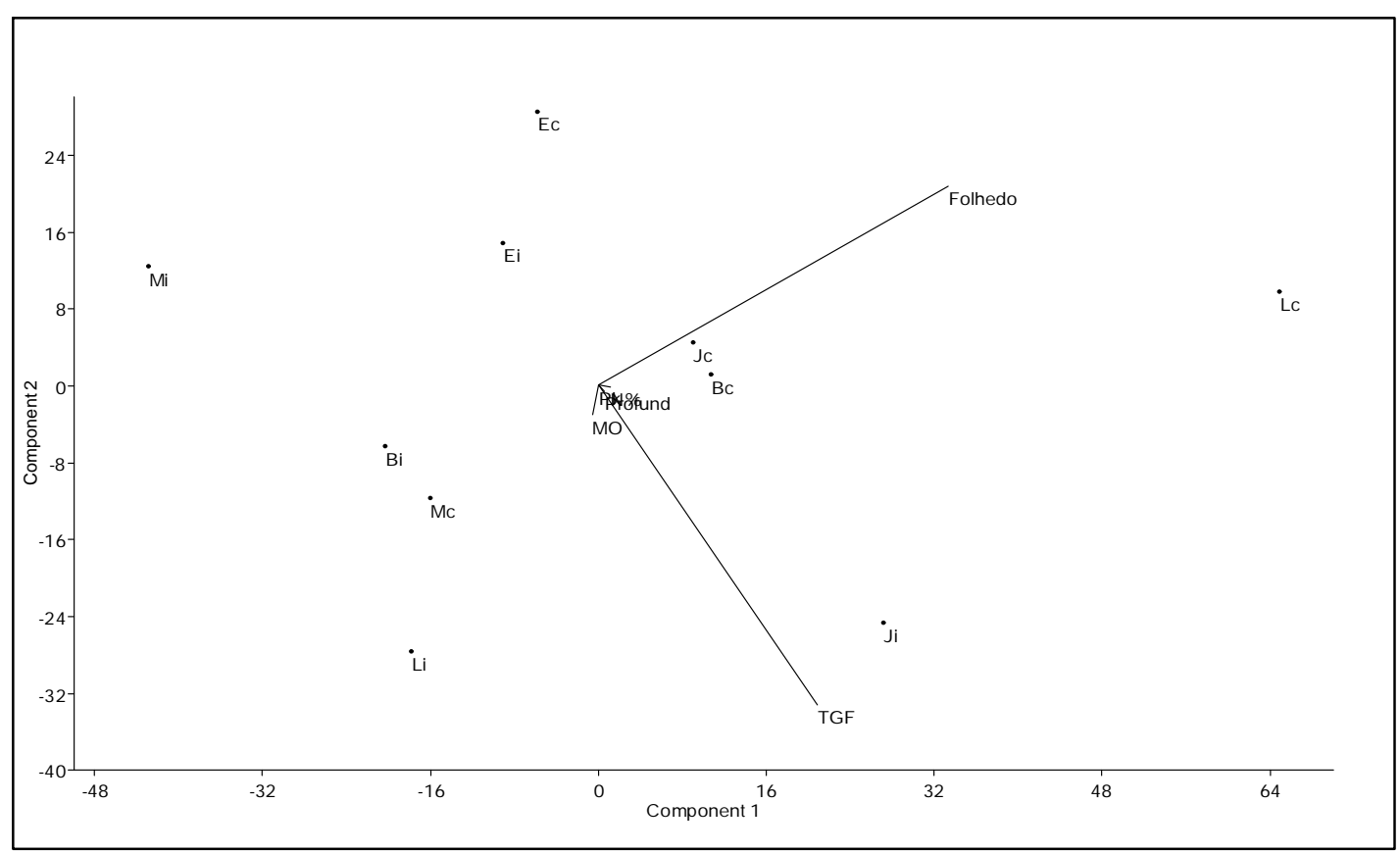

Figura 27. Ordenação através da Análise de Componentes Principais (PCA) das variáveis descritoras das condições abióticas do sedimento no grupo de empreendimentos de passeio de barco, bote e bóia-cross. 


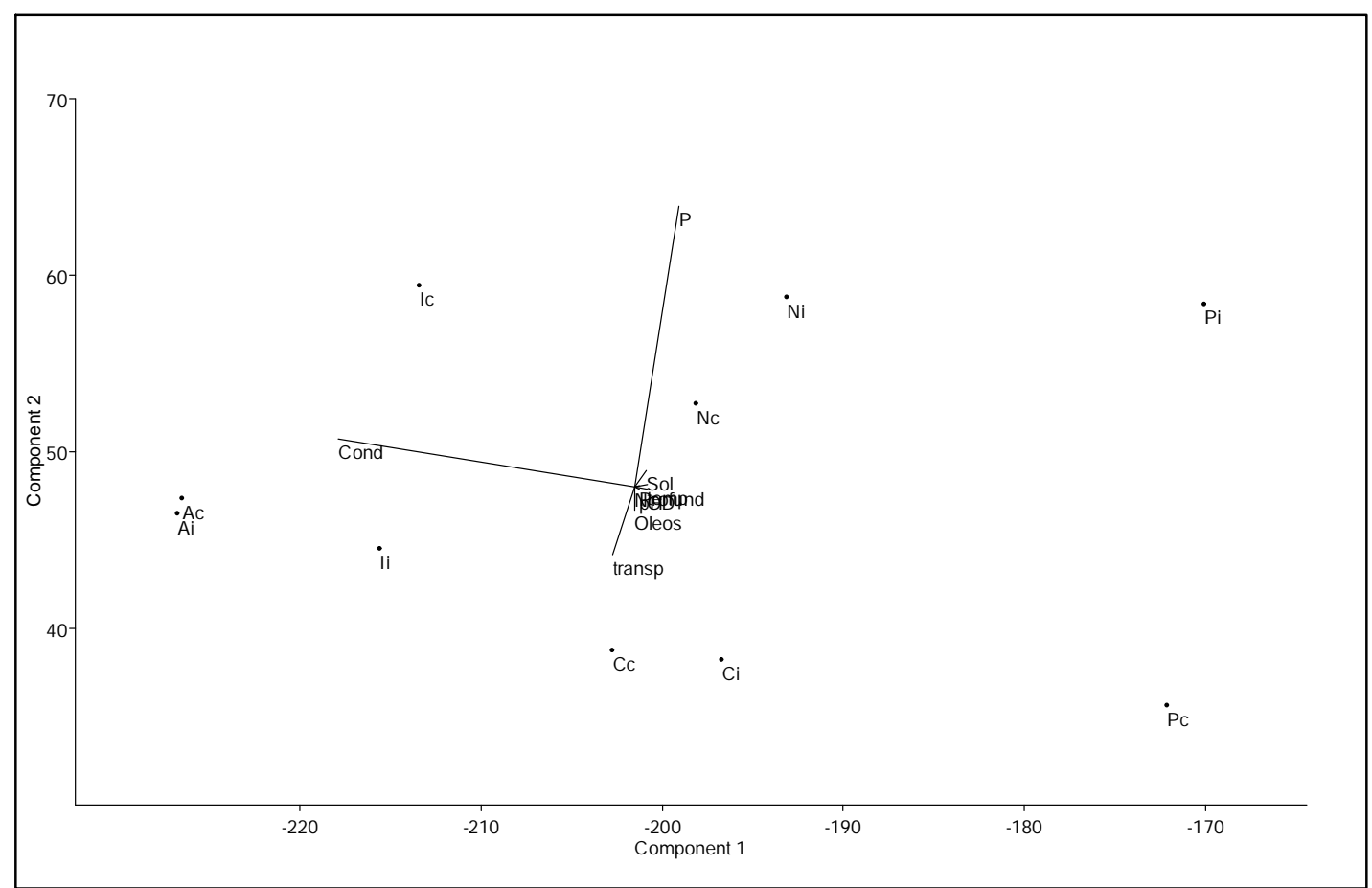

Figura 28. Ordenação através da Análise de Componentes Principais (PCA) das variáveis descritoras das condições abióticas da água no grupo de empreendimentos de banho e flutuação.

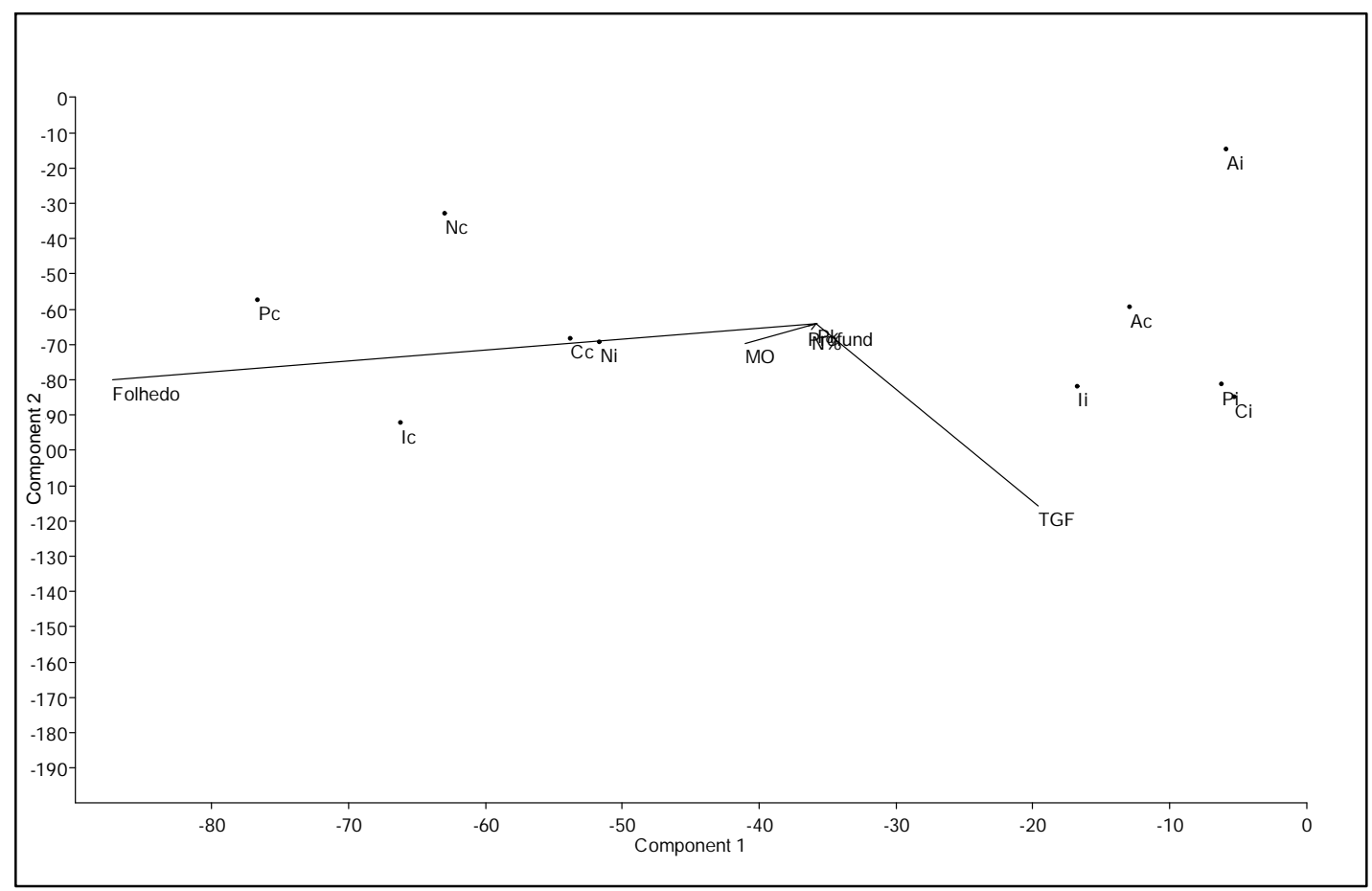

Figura 29. Ordenação através da Análise de Componentes Principais (PCA) das variáveis descritoras das condições abióticas do sedimento no grupo de empreendimentos de banho e flutuação.

Tabela 1. Sumário dos resultados da Análise de Componentes Principais (PCA) das variáveis descritoras das condições abióticas da água nos três grupos de empreendimentos estudados. 


\begin{tabular}{lcccccc}
\hline \hline \multirow{2}{*}{ Variáveis } & \multicolumn{7}{c}{ Grupos de estações e fatores de explicação } \\
& \multicolumn{2}{c}{ Balneário } & Barco, bote e bóia-cross & \multicolumn{2}{c}{ Banho e flutuação } \\
& F 1 & F2 & F1 & F2 & F1 & F2 \\
\hline \hline Profundidade & 0,00 & 0,00 & 0,01 & $-0,07$ & 0,01 & 0,00 \\
Transparência & $-\mathbf{0 , 0 5}$ & 0,09 & 0,11 & 0,25 & $-0,07$ & $\mathbf{0 , 2 3}$ \\
Sólidos suspensos & 0,02 & $-\mathbf{0 , 0 3}$ & $-0,05$ & $-0,08$ & 0,04 & $-0,05$ \\
Temperatura & 0,00 & 0,00 & $-0,05$ & $-0,21$ & 0,04 & $-0,01$ \\
pH & 0,00 & $-0,01$ & $-0,02$ & $-0,04$ & 0,02 & 0,01 \\
Condutividade & 0,00 & $-\mathbf{0 , 9 9}$ & $\mathbf{0 , 5 0}$ & $\mathbf{0 , 7 6}$ & $-\mathbf{0 , 9 8}$ & $-0,16$ \\
Oxigênio dissolvido & 0,00 & $-0,01$ & $-0,06$ & $-0,20$ & 0,04 & 0,01 \\
Óleos e graxas & $-0,01$ & $-0,03$ & 0,03 & 0,11 & 0,00 & 0,08 \\
P total & $\mathbf{1 , 0 0}$ & 0,01 & $-0,86$ & $\mathbf{0 , 5 1}$ & 0,15 & $-\mathbf{0 , 9 6}$ \\
N total & 0,00 & 0,00 & 0,00 & $-0,01$ & 0,00 & 0,00 \\
\% de explicação & 84,33 & 14,98 & 76,36 & 18,98 & 81,42 & 16,54 \\
\hline \hline
\end{tabular}

Tabela 2. Sumário dos resultados da Análise de Componentes Principais (PCA) das variáveis descritoras das condições abióticas do sedimento nos três grupos de empreendimentos estudados.

\begin{tabular}{|c|c|c|c|c|c|c|}
\hline \multirow{3}{*}{ Variáveis } & \multicolumn{6}{|c|}{ Grupos de estações e fatores de explicação } \\
\hline & \multicolumn{2}{|c|}{ Balneário } & \multicolumn{2}{|c|}{ Barco, bote e bóia-cross } & \multicolumn{2}{|c|}{ Banho e flutuação } \\
\hline & $\mathrm{F} 1$ & $\mathrm{~F} 2$ & $\mathrm{~F} 1$ & $\mathrm{~F} 2$ & $\mathrm{~F} 1$ & $\mathrm{~F} 2$ \\
\hline Profundidade & $-0,01$ & 0,00 & 0,01 & $-0,02$ & 0,01 & $-0,01$ \\
\hline Folhedo & $-0,87$ & $-0,50$ & 0,85 & 0,53 & 0,95 & $-0,29$ \\
\hline Matéria orgânica fina & $-0,08$ & 0,14 & $-0,01$ & $-0,08$ & 0,10 & $-0,10$ \\
\hline$P$ total & 0,00 & 0,00 & 0,00 & 0,00 & 0,00 & 0,00 \\
\hline \multirow{2}{*}{$\begin{array}{l}\mathrm{N} \text { total } \\
\text { Textura granulométrica } \\
\text { fina }\end{array}$} & $-0,02$ & 0,01 & 0,03 & 0,00 & 0,01 & $-0,03$ \\
\hline & $-0,49$ & 0,85 & 0,53 & $-0,85$ & $-0,30$ & $-0,95$ \\
\hline \% de explicação & 97,97 & 1,98 & 71,92 & 25,36 & 57,63 & 41,14 \\
\hline
\end{tabular}

Tabela 3. Variação das diferenças entre os pontos de impacto e controle para os valores das variáveis descritoras das condições abióticas da água nos três grupos de empreendimentos estudados. 


\begin{tabular}{|c|c|c|c|c|c|c|c|c|c|c|c|}
\hline \multirow{2}{*}{ 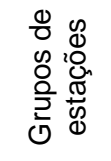 } & \multirow{2}{*}{$\begin{array}{l}\mathscr{D} \\
\mathbb{0} \\
\text { d్ } \\
\mathbb{w} \\
w\end{array}$} & \multicolumn{10}{|c|}{ Variáveis } \\
\hline & & Prof. & Transp & Sol & Temp & $\mathrm{pH}$ & Cond. & OD & Oleos & $P$ & $\mathrm{~N}$ \\
\hline \multirow{5}{*}{ 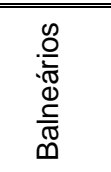 } & "D & - & - & + & + & 0 & - & + & 0 & + & - \\
\hline & $\mathbf{F}$ & - & - & + & + & + & - & + & - & + & - \\
\hline & $\mathbf{G}$ & - & - & + & + & 0 & - & 0 & 0 & - & - \\
\hline & $\mathbf{H}$ & - & - & + & + & 0 & + & - & + & + & + \\
\hline & 0 & - & - & + & - & 0 & 0 & - & 0 & + & - \\
\hline \multirow{5}{*}{ 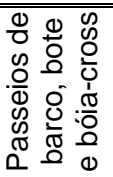 } & B B & + & + & - & 0 & 0 & + & 0 & 0 & - & $\overline{0}$ \\
\hline & $\mathbf{E}$ & + & + & - & + & - & + & - & - & - & + \\
\hline & $\mathbf{J}$ & - & 0 & 0 & 0 & - & + & 0 & - & + & + \\
\hline & $\mathbf{L}$ & - & - & + & - & 0 & - & - & 0 & + & + \\
\hline & $\mathbf{M}$ & - & - & + & 0 & + & + & - & - & + & - \\
\hline \multirow{5}{*}{ 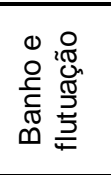 } & $\bar{A}$ & - & + & - & 0 & + & 0 & - & - & - & + \\
\hline & C & - & - & + & - & + & - & - & + & + & + \\
\hline & I & - & - & + & - & + & 0 & + & 0 & - & - \\
\hline & $\mathbf{N}$ & - & - & - & + & 0 & - & + & 0 & + & 0 \\
\hline & $\mathbf{P}$ & - & 0 & 0 & - & - & + & + & - & + & + \\
\hline
\end{tabular}

Tabela 4. Variação das diferenças entre os pontos de impacto e controle para os valores das variáveis descritoras das condições abióticas do sedimento nos três grupos de empreendimentos estudados. 


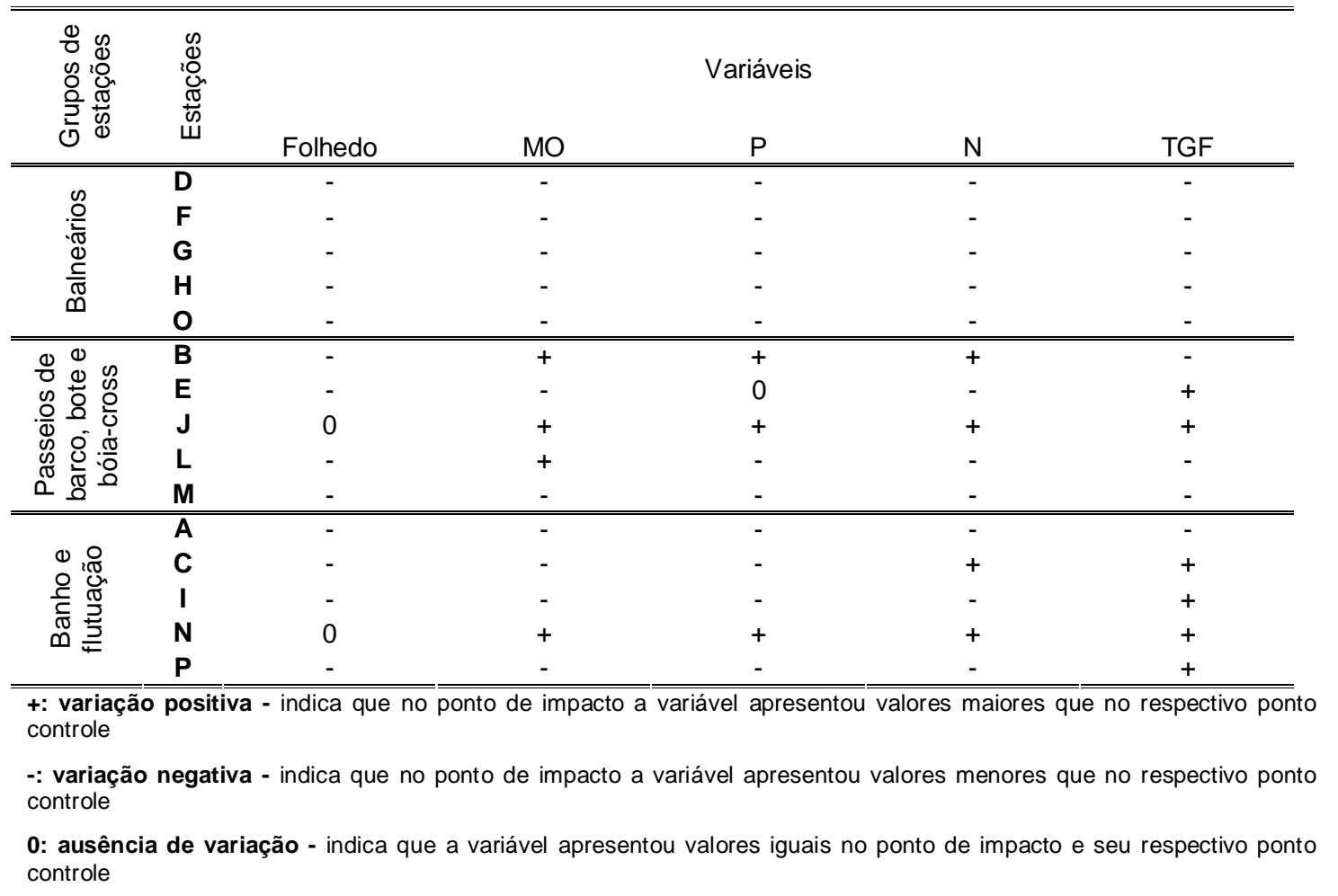

\subsection{Macroinvertebrados bentônicos}

Os resultados das variáveis descritoras da estrutura de comunidades obtidas para os macroinvertebrados bentônicos coletados nos diferentes pontos estudados encontramse sumariados nos Anexos 8 e 9, respectivamente.

Os resultados obtidos a partir da Análise de Correspondência para a abundância total dos táxons evidenciaram uma leve ordenação entre os táxons $5,10,18,30$ e 33 (Chironomidae, Ephemeroptera 1, Gomphidae, Oligochaeta e Ostracoda) e os pontos de impactos dos balneários D, F e G (Di, Fi e Gi) (Figura 30).

Para os grupos de passeios de barco, bote e bóia-cross e banho e flutuação não se evidenciou ordenação entre a densidade total dos táxons e os pontos de controle ou impacto (Figuras 31 e 32). Entretanto, é possível observar uma leve tendência de associação entre os pontos de impacto e os de controle nas estações E e M, no grupo de 
passeio de barco, bote e bóia-cross e nas estações $A$ e $C$, no grupo de banho e flutuação.

Através da Análise de Variância (ANOVA) dois critérios, considerando métricas descritoras da estrutura de comunidades para os macroinvertebrados bentônicos, verificou-se que os balneários apresentaram diferenças significativas $(p<0,05)$ de riqueza e índice de diversidade taxonômica entre os pontos de impacto e controle das estações amostradas. O grupo de banho e flutuação também exibiu diferença significativa entre impacto e controle, porém apenas para a métrica riqueza taxonômica (Tabela 6).

Assim como as variáveis abióticas, as variáveis bióticas também exibiram variação espacial através da ANOVA. Verificou-se diferenças significativas $(p<0,05)$ de riqueza e diversidade taxonômica entre as estações de amostragem tanto do grupo de passeios de barco, bote e bóia-cross quanto do grupo de banho e flutuação (Tabela 6).

A diferença significativa entre impacto e controle ficou bem evidente para o grupo de balneários, enquanto a diferença entre estações de amostragem ficou mais evidente para os demais grupos. Essas diferenças foram expressas sempre para os descritores riqueza ou índice de diversidade taxonômica, enquanto que os dados de abundancia de indivíduos não apresentaram diferença significativa nas situações analisadas (Tabela 6).

Quanto à regularidade na diferença dos valores das variáveis bióticas nos pontos de impacto em relação aos respectivos pontos controle, riqueza taxonômica e índice de diversidade taxonômica exibiram variação negativa em ao menos $80 \%$ das estações, nos três grupos de estações considerados. Nenhuma dessas variáveis exibiu variação positiva. A variável abundância de indivíduos, entretanto, não manteve regularidade de variação em nenhum dos três grupos (Tabela 7). 


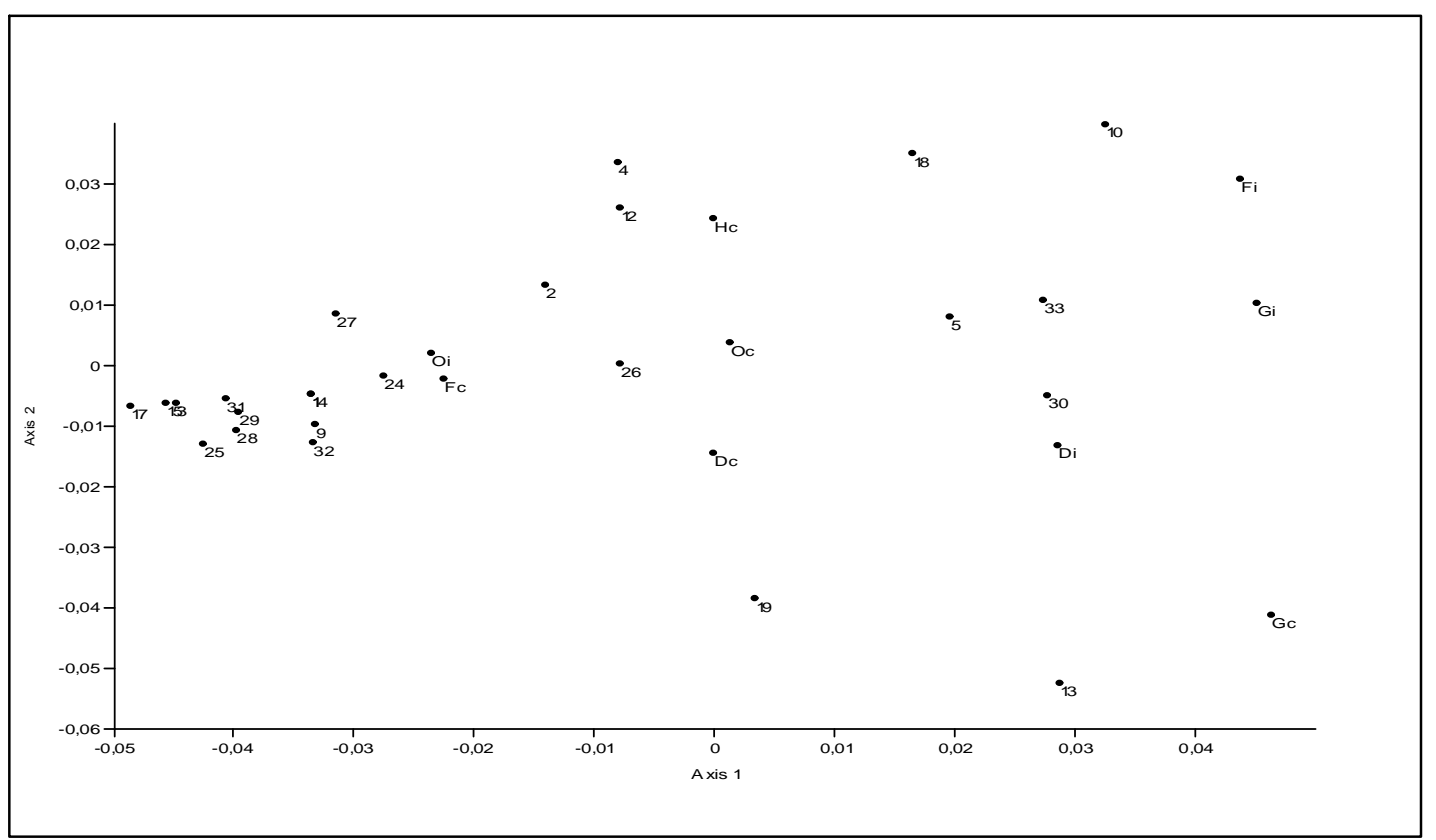

Figura 30. Ordenação através de Análise de Correspondência dos táxons de macroinvertebrados bentônicos e pontos de controle e impacto no grupo de balneários. Códigos e respectivas identidades dos táxons na Tabela 3.

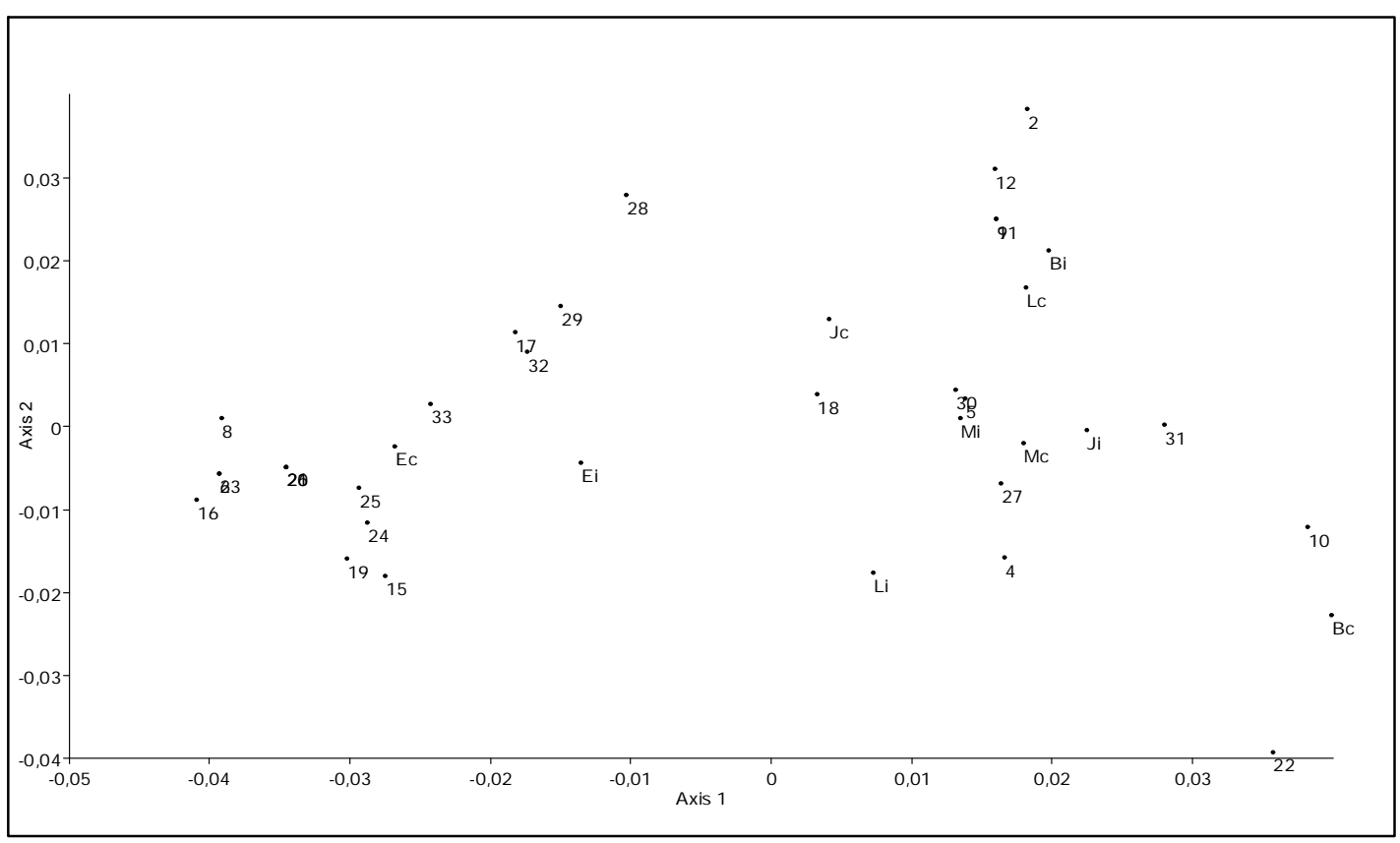

Figura 31. Ordenação através de Análise de Correspondência dos táxons de macroinvertebrados bentônicos e pontos de controle e impacto no grupo de grupo de empreendimentos de passeio de barco, bote e bóia-cross. Códigos e respectivas identidades dos táxons na Tabela 3. 


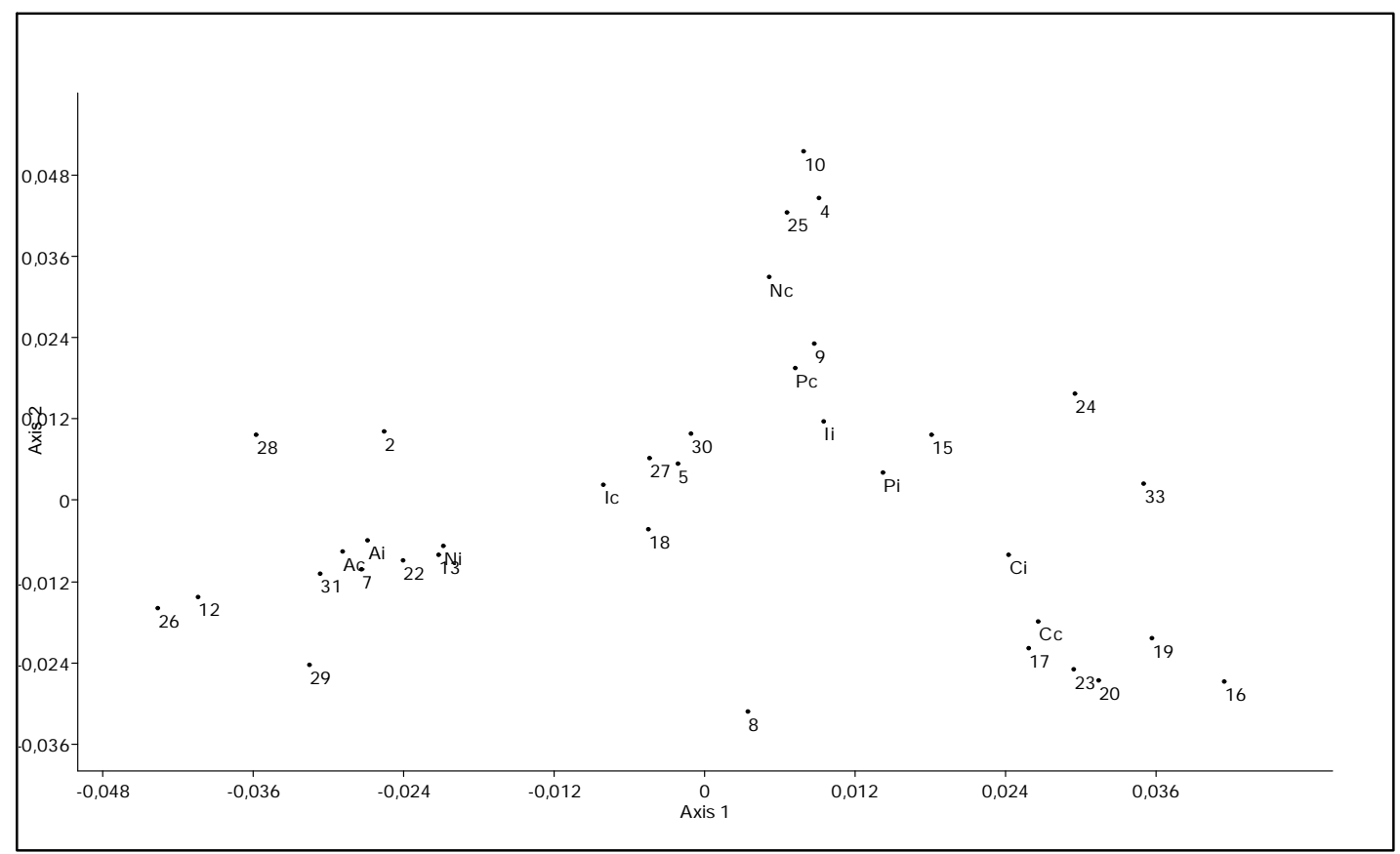

Figura 32. Ordenação através de Análise de Correspondência dos táxons de macroinvertebrados bentônicos e pontos de controle e impacto no grupo de grupo de empreendimentos de banho e flutuação. Códigos e respectivas identidades dos táxons na Tabela 5.

Tabela 5. Lista de táxons coletados nos diferentes estações de coleta ao longo do Rio Formoso, Bonito, MS, com seus respectivos códigos numéricos.

\begin{tabular}{|c|c|c|c|}
\hline Taxon & Código & Taxon & Código \\
\hline Colembolla & 1 & Odonata & \\
\hline Coleoptera & & Coenagrionidae & 17 \\
\hline Elmidae & 2 & Gomphidae & 18 \\
\hline Dytiscidae & 3 & Libellulidae & 19 \\
\hline Diptera & & Trichoptera & \\
\hline Ceratopogonidae & 4 & Calamoceratidae & 20 \\
\hline Chironomidae & 5 & Trichoptera 1 & 21 \\
\hline Simuliidae & 6 & Helicopsychidae & 22 \\
\hline Tipulidae & 7 & Hydroptilidae & 23 \\
\hline Ephemeroptera & & Leptoceridae & 24 \\
\hline Baetidae & 8 & Polycentropodidae & 25 \\
\hline Caenidae & 9 & Philopotamidae & 26 \\
\hline Ephemeroptera 1 & 10 & Gastropoda & 27 \\
\hline Ephemeroptera 2 & 11 & Bivalvia & 28 \\
\hline Leptophlebiidae & 12 & Hirudinea & 29 \\
\hline Polymitarcyidae & 13 & Oligochaeta & 30 \\
\hline Ephemeroptera 3 & 14 & Tuberllaria & 31 \\
\hline Trichorythidae & 15 & Decapoda & 32 \\
\hline Lepidoptera & & Ostracoda & 33 \\
\hline Pyralidae & 16 & & \\
\hline
\end{tabular}


Tabela 6. Resultados da Análise de Variância dois critérios para a riqueza de táxons, abundância total e valores de índice de diversidade de Shannon como variáveis dependentes e pontos controle e impacto como tratamentos e estações de amostragem como blocos.

\begin{tabular}{|c|c|c|c|c|c|c|c|}
\hline $\begin{array}{l}\text { Grupo de } \\
\text { estações }\end{array}$ & Variáveis & $\begin{array}{l}\text { Fontes de } \\
\text { Variação }\end{array}$ & $\begin{array}{c}\text { Graus de } \\
\text { Liberdade }\end{array}$ & $\begin{array}{l}\text { Soma dos } \\
\text { Quadrados }\end{array}$ & $\begin{array}{l}\text { Quadrado } \\
\text { Médio }\end{array}$ & $\mathbf{F}$ & $\mathbf{p}$ \\
\hline \multirow{9}{*}{ Balneários } & \multirow{3}{*}{ Riqueza } & Tratamentos & 1 & 108,90 & 108,90 & 9,77 & 0,04 \\
\hline & & Blocos & 4 & 132,60 & 33,15 & 2,97 & 0,16 \\
\hline & & Erro & 4 & 44,60 & 11,15 & & \\
\hline & \multirow{3}{*}{ Abundância } & Tratamentos & 1 & 207152,69 & 207152,69 & 0,92 & 0,61 \\
\hline & & Blocos & 4 & 2981444,90 & 745361,24 & 3,32 & 0,14 \\
\hline & & Erro & 4 & 897772,86 & 224443,21 & & \\
\hline & \multirow{3}{*}{$\begin{array}{c}\text { Índice de } \\
\text { diversidade }\end{array}$} & Tratamentos & 1 & 2,63 & 2,63 & 9,52 & 0,04 \\
\hline & & Blocos & 4 & 3,72 & 0,93 & 3,36 & 0,13 \\
\hline & & Erro & 4 & 1,11 & 0,28 & & \\
\hline \multirow{9}{*}{$\begin{array}{l}\text { Passeios de } \\
\text { barco, bote } \\
\text { e bóia-cross }\end{array}$} & \multirow{3}{*}{ Riqueza } & Tratamentos & 1 & 22,50 & 22,50 & 5,63 & 0,08 \\
\hline & & Blocos & 4 & 324,40 & 81,10 & 20,28 & 0,01 \\
\hline & & Erro & 4 & 16,00 & 4,00 & & \\
\hline & \multirow{3}{*}{ Abundância } & Tratamentos & 1 & 718947,69 & 718947,69 & 1,32 & 0,32 \\
\hline & & Blocos & 4 & 2898673,20 & 724668,30 & 1,33 & 0,39 \\
\hline & & Erro & 4 & 2177303,20 & 544325,79 & & \\
\hline & \multirow{3}{*}{$\begin{array}{c}\text { Índice de } \\
\text { Diversidade }\end{array}$} & Tratamentos & 1 & 0,19 & 0,19 & 2,68 & 0,18 \\
\hline & & Blocos & 4 & 11,41 & 2,85 & 40,18 & 0,00 \\
\hline & & Erro & 4 & 0,28 & 0,07 & & \\
\hline \multirow{9}{*}{$\begin{array}{l}\text { Banho e } \\
\text { flutuação }\end{array}$} & \multirow{3}{*}{ Riqueza } & Tratamentos & 1 & 14,40 & 14,40 & 96,00 & 0,00 \\
\hline & & Blocos & 4 & 68,60 & 17,15 & $\begin{array}{c}114,3 \\
3\end{array}$ & 0,00 \\
\hline & & Erro & 4 & 0,60 & 0,15 & & \\
\hline & \multirow{3}{*}{ Abundância } & Tratamentos & 1 & 599064,79 & 599064,79 & 1,73 & 0,26 \\
\hline & & Blocos & 4 & 2344300,10 & 586075,03 & 1,70 & 0,31 \\
\hline & & Erro & 4 & 1382621,50 & 345655,39 & & \\
\hline & \multirow{3}{*}{$\begin{array}{c}\text { Índice de } \\
\text { Diversidade }\end{array}$} & Tratamentos & 1 & 0,33 & 0,33 & 3,80 & 0,12 \\
\hline & & Blocos & 4 & 6,07 & 1,52 & 17,38 & 0,01 \\
\hline & & Erro & 4 & 0,35 & 0,09 & & \\
\hline
\end{tabular}


Tabela 7. Variação das diferenças entre os pontos de impacto e controle para os valores das variáveis descritoras da estrutura de comunidades para os macroinvertebrados bentônicos nos três grupos de empreendimentos estudados.

\begin{tabular}{|c|c|c|c|c|}
\hline \multirow{2}{*}{ 足 } & \multirow{2}{*}{ 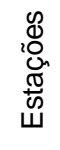 } & \multicolumn{3}{|c|}{ Variáveis } \\
\hline & & Riqueza & Abundância & Índice de diversidade \\
\hline \multirow{5}{*}{ 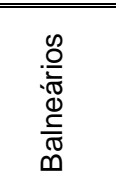 } & $\overline{\mathbf{D}}$ & - & - & - \\
\hline & $\mathbf{F}$ & - & + & - \\
\hline & $\mathbf{G}$ & 0 & - & - \\
\hline & $\mathbf{H}$ & - & - & - \\
\hline & 0 & - & - & - \\
\hline \multirow{5}{*}{ 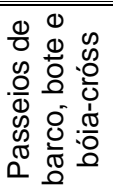 } & B & 0 & - & 0 \\
\hline & $\mathbf{E}$ & - & - & - \\
\hline & $J$ & - & + & - \\
\hline & $\mathbf{L}$ & - & - & - \\
\hline & $\mathbf{M}$ & - & - & - \\
\hline \multirow{5}{*}{ 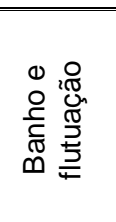 } & $\mathbf{A}$ & - & - & - \\
\hline & C & - & - & - \\
\hline & I & - & - & - \\
\hline & $\mathbf{N}$ & - & - & - \\
\hline & $\mathbf{P}$ & - & + & - \\
\hline
\end{tabular}

+: variação positiva - indica que no ponto de impacto a variável apresentou valores maiores que no respectivo ponto controle

-: variação negativa - indica que no ponto de impacto a variável apresentou valores menores que no respectivo ponto controle

0: ausência de variação - indica que a variável apresentou valores iguais no ponto de impacto e seu respectivo ponto controle 


\subsection{Estrutura física do ecossistema}

Os grupos de balneários e banho e flutuação exibiram os maiores valores do Índice de Alteração da Estrutura Física de Ecossistemas (IAEFE) (Figuras 33 e 34). Essa situação se repetiu para os valores de todos os descritores que compuseram o IAEFE, com exceção de tufas calcárias, cujos maiores valores de alteração foram medidos para o grupo de passeio de barco, bote e bóia-cross (Figura 34). Os valores do IAEFE e dos descritores de alteração exibiram grande variação entre as estações de amostragem em todos os grupos de estações estudados (Figura 33 e Tabela 8).

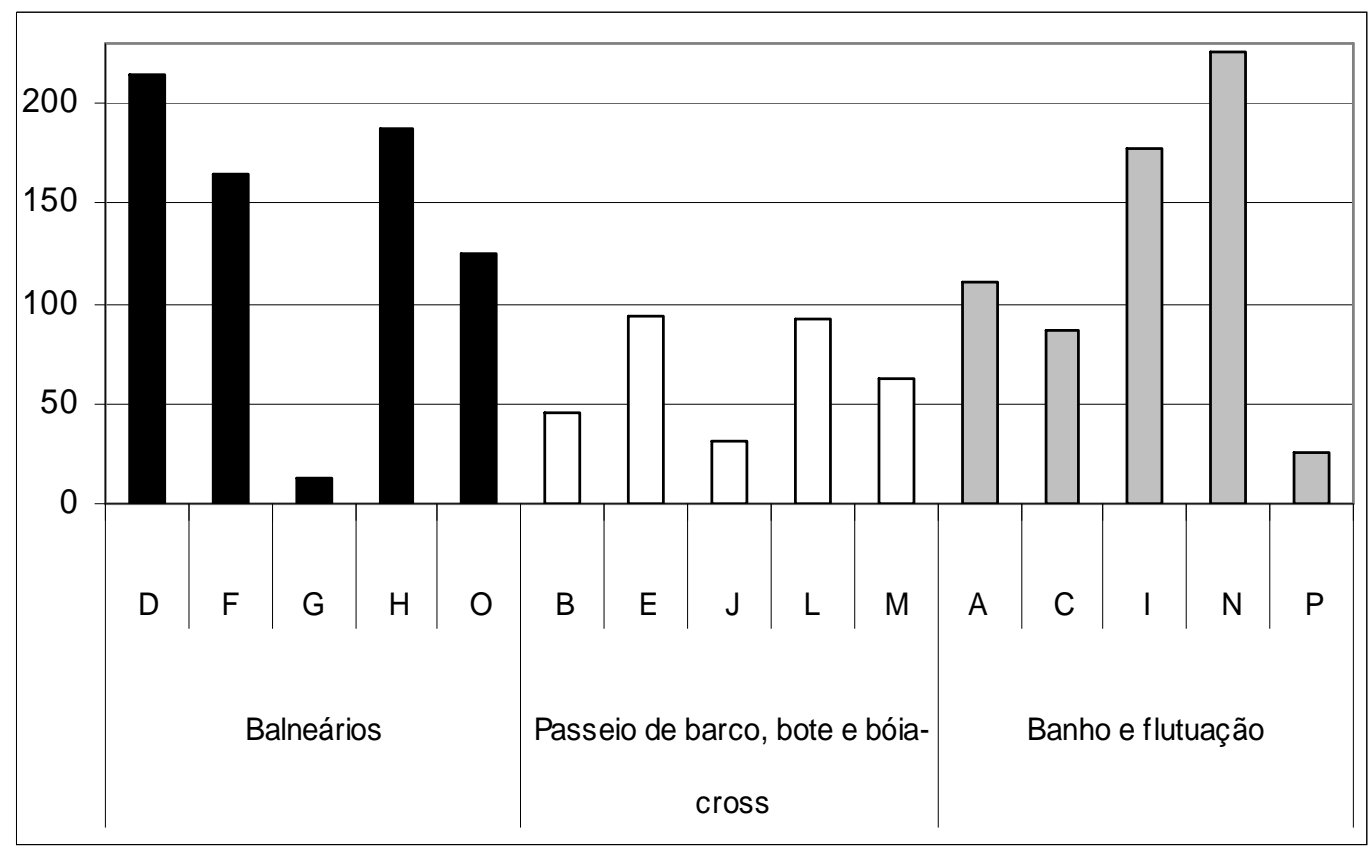

Figura 33. Índice de Alteração da Estrutura Física de Ecossistemas (IAEFE) medida nos três grupos de estações de amostragem. 


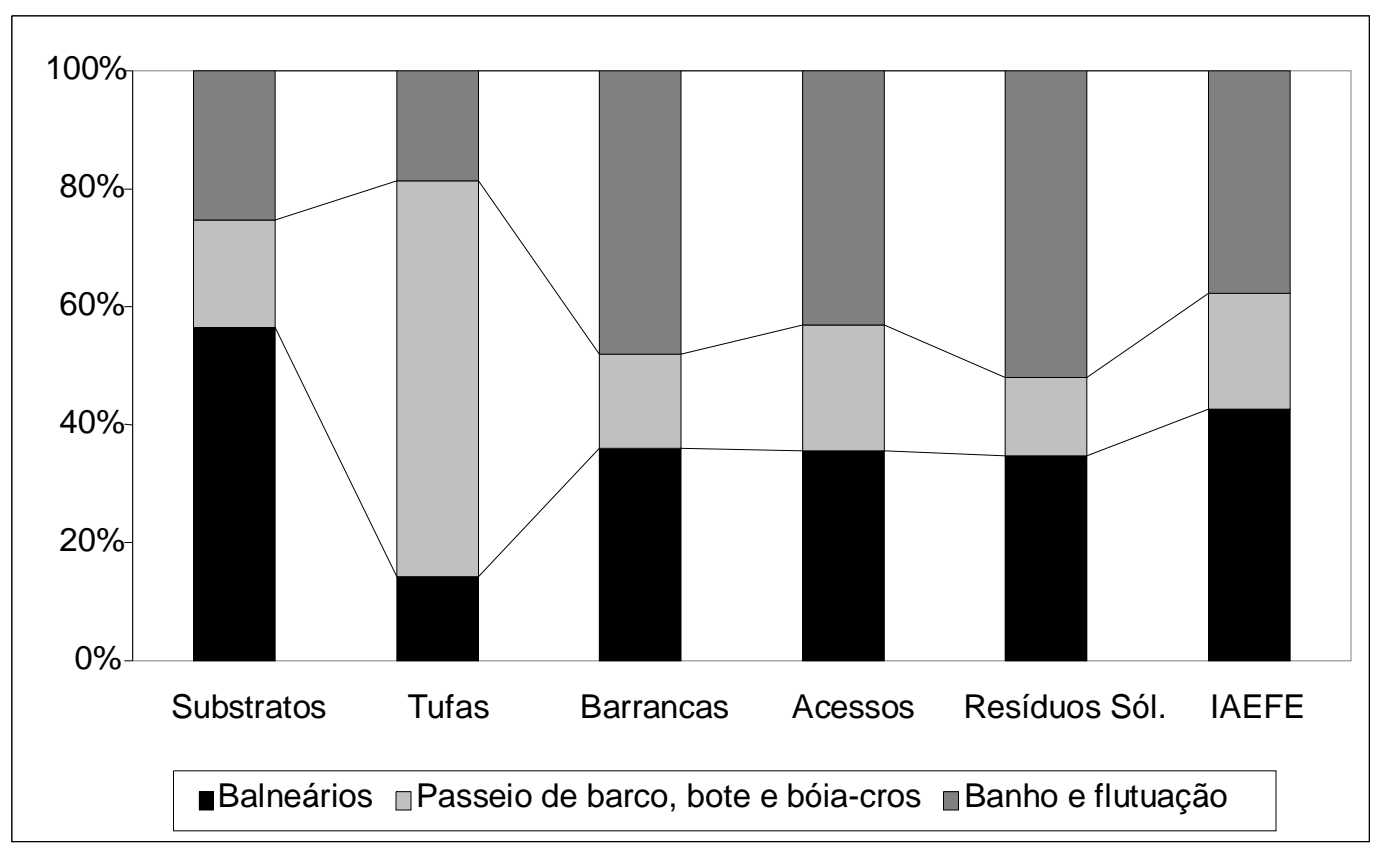

Figura 34. Participação dos três grupos de empreendimentos nos valores totais medidos para os descritores de alteração da estrutura física de ecossistemas e para o IAEFE.

Tabela 8. Resultados da avaliação visual para composição do Índice de Alteração da Estrutura Física de Ecossistemas (IAEFE) nos três grupos de estações estudadas.

\begin{tabular}{|c|c|c|c|c|c|c|c|}
\hline $\begin{array}{l}\text { Grupos de } \\
\text { Estações }\end{array}$ & $\begin{array}{c}\text { Estaçõ } \\
\text { es }\end{array}$ & $\begin{array}{c}\text { Diversidade e } \\
\text { estabilidade } \\
\text { de substratos } \\
\text { de fundo }\end{array}$ & $\begin{array}{c}\text { Estabilidad } \\
\text { e das tufas } \\
\text { calcárias }\end{array}$ & $\begin{array}{c}\text { Estabilidad } \\
\text { e das } \\
\text { barrancas }\end{array}$ & $\begin{array}{l}\text { Acessos } \\
\text { secundário } \\
\text { s ao rio }\end{array}$ & $\begin{array}{c}\text { Presença } \\
\text { de } \\
\text { resíduos } \\
\text { sólidos } \\
\text { nas } \\
\text { margens }\end{array}$ & IAEFE \\
\hline \multirow{5}{*}{ Balneários } & $\bar{D}$ & 137 & 20 & 52 & 5 & 1 & 215 \\
\hline & $\mathrm{F}$ & 73 & 13 & 70 & 8 & 1 & 165 \\
\hline & $\mathrm{G}$ & 13 & 0 & 0 & 0 & 0 & 13 \\
\hline & $\mathrm{H}$ & 109 & 10 & 59 & 7 & 3 & 188 \\
\hline & $\mathrm{O}$ & 19 & 3 & 92 & 8 & 3 & 125 \\
\hline \multirow{5}{*}{$\begin{array}{l}\text { Passeios de } \\
\text { barco, bote } \\
\text { e bóia- } \\
\text { cross }\end{array}$} & $\bar{B}$ & 36 & * & 8 & 2 & 0 & 46 \\
\hline & $\mathrm{E}$ & 34 & 53 & 3 & 3 & 1 & 94 \\
\hline & $J$ & 16 & 60 & 7 & 2 & 0 & 31 \\
\hline & $\mathrm{L}$ & 14 & 50 & 68 & 7 & 1 & 92 \\
\hline & $\mathrm{M}$ & 13 & 50 & 35 & 3 & 1 & 62 \\
\hline \multirow{5}{*}{$\begin{array}{c}\text { Banho e } \\
\text { flutuação }\end{array}$} & A & 76 & * & 31 & 4 & 0 & 111 \\
\hline & C & 35 & 28 & 18 & 4 & 1 & 86 \\
\hline & I & 14 & 10 & 142 & 10 & 1 & 177 \\
\hline & $\mathrm{N}$ & 24 & 22 & 156 & 14 & 10 & 226 \\
\hline & $\mathrm{P}$ & 7 & * & 16 & 2 & 0 & 25 \\
\hline
\end{tabular}

$\overline{{ }^{*} \text { não há ocorrência de tufas calcárias na estação de amostragem }}$ 


\subsection{Seleção de indicadores}

$\mathrm{Na}$ seleção de indicadores, apenas no grupo de balneários foram verificadas variáveis descritoras das condições da água que atenderam ao menos $50 \%$ da pontuação máxima de importância (importância $\geq 15$ ). Essas variáveis foram profundidade, transparência e sólidos suspensos, com 23, 23 e 21 pontos de importância, respectivamente (Tabela 9).

A baixa importância das variáveis abióticas da água na distinção dos impactos da visitação pública sobre o rio Formoso ficou evidente nas análises de PCA (Figuras 24, 26 e 28), através da quais não se verificou distinções entre pontos de impacto e controle nos três dos grupos de estações. Através dessas análises ficou evidente que as variações que ocorrem ao longo do rio Formoso, ou seja, entre as estações amostradas, se sobressaíram em relação às variações impacto versus controle. Em outros trabalhos realizados em ambientes aquáticos visitados, as variáveis físicas e químicas da água refletiram muito mais as condições naturais do ambiente, as características da bacia de drenagem e outras condições ambientais, do que os efeitos da visitação pública sobre o ecossistema aquático propriamente dito (MAGRO et al., 2001; OENNING, 2003; DOMINGOS, 2002; QUEIROZ, 2006).

Dentre as estações estudadas, os balneários envolvem atividades que provocam o maior grau de movimentação da água e contato com o fundo do ambiente por parte do visitante. Essas interferências resultam na ressuspensão dos sedimentos, com conseqüente aumento na concentração de sólidos suspensos e redução na transparência da água. Em função das características inerentes à atividade, os balneários estão localizados em trechos do rio com baixa profundidade da coluna d'água, o que facilita o contínuo deslocamento do visitante em contato com o fundo do ecossistema, acelerando a ressuspensão dos sedimentos, os quais já são naturalmente pouco consolidados devido às características geológicas da região (ver item 2.1). Nesse caso, a variável profundidade da água reflete, então, as condições naturais do sistema e não os impactos 
da visitação pública. Essa variável pode, inclusive, facilitar e potencializar as alterações provocadas sobre a concentração de sólidos suspensos e transparência da água.

Tabela 9. Seleção de indicadores de impactos da visitação pública a partir da análise das variáveis descritoras das condições abióticas da água nos três grupos de empreendimentos estudados, conforme critérios apresentados no item 2.5 .

\begin{tabular}{|c|c|c|c|c|c|c|c|c|}
\hline 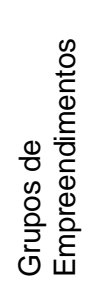 & Variáveis & 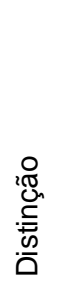 & 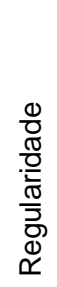 & 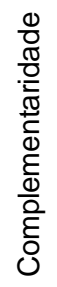 & 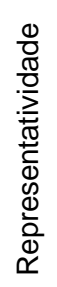 & 弯 & $\begin{array}{l}\frac{0}{0} \\
\frac{\pi}{0} \\
. \frac{0}{0} \\
\frac{0}{0} \\
\overline{0}\end{array}$ & 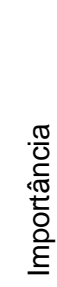 \\
\hline \multirow{10}{*}{ 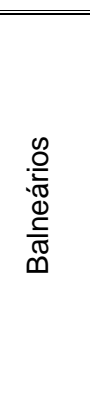 } & Profundidade & & 5 & 3 & 5 & 5 & 5 & 23 \\
\hline & Transparência & & 5 & 3 & 5 & 5 & 5 & 23 \\
\hline & Sólidos suspensos & & 5 & 3 & 5 & 3 & 5 & 21 \\
\hline & Temperatura & & & & & & & \\
\hline & $\mathrm{pH}$ & & & & & & & \\
\hline & Condutividade & & & & & & & \\
\hline & Oxigênio dissolvido & & & & & & & \\
\hline & Óleos e graxas & & & & & & & \\
\hline & $\mathrm{P}$ total & & & & & & & \\
\hline & $\mathrm{N}$ total & & & & & & & \\
\hline \multirow{10}{*}{ 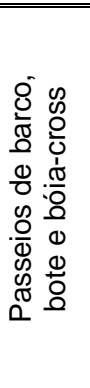 } & Profundidade & & & & & & & \\
\hline & Transparência & & & & & & & \\
\hline & Sólidos suspensos & & & & & & & \\
\hline & Temperatura & & & & & & & \\
\hline & $\mathrm{pH}$ & & & & & & & \\
\hline & Condutividade & & & & & & & \\
\hline & Oxigênio dissolvido & & & & & & & \\
\hline & Óleos e graxas & & & & & & & \\
\hline & $\mathrm{P}$ total & & & & & & & \\
\hline & $\mathrm{N}$ total & & & & & & & \\
\hline \multirow{10}{*}{ 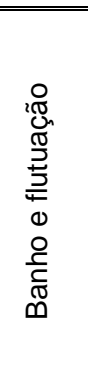 } & Profundidade & & 5 & & & & & 5 \\
\hline & Transparência & & & & & & & \\
\hline & Sólidos suspensos & & & & & & & \\
\hline & Temperatura & & & & & & & \\
\hline & $\mathrm{pH}$ & & & & & & & \\
\hline & Condutividade & & & & & & & \\
\hline & Oxigênio dissolvido & & & & & & & \\
\hline & Óleos e graxas & & & & & & & \\
\hline & $P$ total & & & & & & & \\
\hline & $\mathrm{N}$ total & & & & & & & \\
\hline
\end{tabular}

Devido ao fluxo dos cursos d’água, as variáveis sólidos suspensos e transparência da água indicam alterações momentâneas nas condições da água. Adicionalmente, no caso dos ecossistemas inseridos no Planalto da Bodoquena os carbonatos presentes em alta concentração atuam promovendo a rápida floculação e sedimentação dos sólidos suspensos (ver item 2.1), aumentando a transparência da 
água. Assim, essas variáveis respondem com eficiência apenas às interferências mais pronunciadas e contínuas que atingem o sedimento de fundo. Por isso, não são boas indicadoras para os impactos provocados por passeios de barco, bote e bóia-cross e banho e flutuação. Nessas atividades, a ressuspensão de sedimentos, quando ocorre, se dá de forma pontual e descontínua, a exemplo da provocada pelo pisoteio do fundo no momento do embarque nos botes, em dois dos três empreendimentos que realizam esse passeio.

Como transparência da água e sólidos suspensos apresentaram alta correlação linear $(-0,95122, p<0,05)$, é recomendável a adoção da primeira como indicador dos impactos da visitação sobre o compartimento água nos balneários, uma vez que esta variável exibiu a maior pontuação de importância. Nos demais grupos de estações/empreendimentos, nenhuma variável dentre as avaliadas atuaria de maneira satisfatória como indicadora dos impactos da visitação pública sobre as condições abióticas da água.

Dentre as variáveis descritoras das condições do sedimento, apenas fósforo total (P total) não obteve pontuação de importância $\geq 15$ para o grupo de balneários, sendo que as maiores pontuações foram exibidas pelas variáveis folhedo e textura granulométrica fina (Tabela 10). Como folhedo apresentou alta correlação linear com todas as demais variáveis pontuadas (correlação de 0,91475 com matéria orgânica; 0,59814 com fósforo total; 0,98111 com nitrogênio total e 0,94816 com textura granulométrica fina, sendo $p<0,05)$ e apresenta baixo custo e praticidade de obtenção e interpretação, foi selecionada como melhor variável indicadora dos impactos da visitação pública sobre as condições abióticas do sedimento em balneários.

Nos demais grupos, folhedo também se destacou, sendo a única variável a atingir a pontuação mínima (Tabela 10). Apesar de textura granulométrica fina ter distinguido os pontos de impacto nas análises de PCA (Figuras, 25, 27 e 29), a variação de seus valores apresentou regularidade apenas para balneários (Tabelas 4 e 10). Assim, folhedo 
representa o melhor indicador abiótico do compartimento sedimento também para os demais grupos de estações.

Tabela 10. Seleção de indicadores de impactos da visitação pública a partir da análise das variáveis descritoras das condições abióticas do sedimento nos três grupos de empreendimentos estudados, conforme critérios apresentados no item 2.5 .

\begin{tabular}{|c|c|c|c|c|c|c|c|c|}
\hline 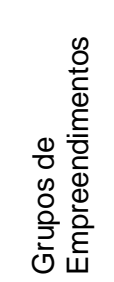 & Variáveis & 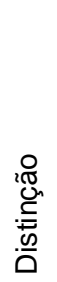 & $\begin{array}{l}\frac{0}{0} \\
\frac{\pi}{0} \\
: \frac{0}{\pi} \\
\frac{0}{5} \\
\frac{0}{1} \\
\simeq\end{array}$ & 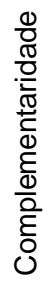 & 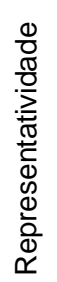 & $\begin{array}{l}\stackrel{\circ}{\text { N }} \\
\stackrel{J}{0}\end{array}$ & $\begin{array}{l}\frac{0}{0} \\
\frac{\pi}{0} \\
.00 \\
: 0 \\
\frac{\pi}{0} \\
0\end{array}$ & 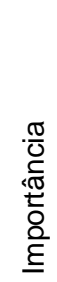 \\
\hline \multirow{5}{*}{ 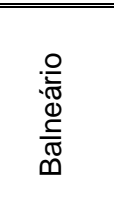 } & Folhedo & 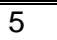 & 5 & 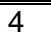 & 3 & 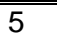 & $\overline{5}$ & 23 \\
\hline & Matéria orgânica fina & & 5 & 4 & 2 & 3 & 5 & 15 \\
\hline & $P$ total & & 5 & 1 & 1 & 3 & 5 & 14 \\
\hline & $\mathrm{N}$ total & & 5 & 3 & 3 & 3 & 5 & 16 \\
\hline & Textura granulométrica fina & 3 & 5 & 4 & 3 & 3 & 5 & 19 \\
\hline \multirow{5}{*}{ 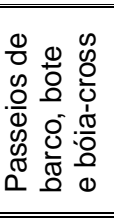 } & Folhedo & 5 & 4 & & & 5 & 5 & 19 \\
\hline & Matéria orgânica fina & & & & & & & - \\
\hline & P total & & & & & & & - \\
\hline & $\mathrm{N}$ total & & & & & & & - \\
\hline & Textura granulométrica fina & 3 & & & & & & - \\
\hline \multirow{5}{*}{ 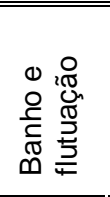 } & Folhedo & 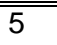 & 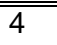 & & & 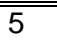 & 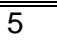 & 19 \\
\hline & Matéria orgânica fina & & & & & 3 & 5 & - \\
\hline & $P$ total & & & & & 3 & 5 & - \\
\hline & $\mathrm{N}$ total & & & & & 3 & 5 & - \\
\hline & Textura granulométrica fina & 2 & & & & 3 & 5 & - \\
\hline
\end{tabular}

A elevada pontuação e, principalmente, a regularidade na variação das variáveis no grupo de balneários destaca a sensibilidade das condições abióticas do sedimento às alterações provocadas pela visitação pública nesse tipo de empreendimento. Assim como verificado para algumas variáveis abióticas da água, as condições abióticas do sedimento distinguiram de maneira mais clara o alto grau de interferência do visitante sobre 0 compartimento de fundo nos trechos do rio Formoso utilizados pelos balneários. $O$ pisoteio e movimentação intensa ocasionados por essa atividade promovem a desagregação do sedimento e a conseqüente ressuspensão e carreamento do folhedo, matéria orgânica fina e textura granulométrica fina. Por constituírem substratos leves e inconsistentes, esses materiais estão mais susceptíveis à desagregação mecânica e ao transporte rio abaixo pela ação hidrológica (CHRISTOFOLETTI, 1981). De acordo com Beschta (1996), o transporte desses sólidos é influenciado tanto pela velocidade da água como pela turbulência do sistema. As formas de nutrientes ( $\mathrm{P}$ total e $\mathrm{N}$ total), como estão associados principalmente à reservatórios de matéria orgânica (MEYBECK, 1982), são indiretamente afetados pela desagregação e deslocamento da matéria orgânica fina e folhedo. 
A elevada distinção e regularidade na variação dos valores de folhedo, com as menores concentrações nos pontos de impacto, está relacionada á sua dinâmica nos cursos d'água. Esse tipo de substrato geralmente se acumula em pontos ou zonas específicas do ecossistema formando "pacotes" de folhas pressionadas pela corrente contra troncos ou rochas, ou depositadas em regiões de menor energia hidráulica, como locais de remansos (HYNES, 1970; KEMP, et al, 2000). A turbulência adicional provocada pelas atividades de banho e flutuação e passeios de barco, bote e bóia-cross não são tão conspícuas quanto o pisoteio que ocorre nos balneários, mas são suficientes para desacomodar e deslocar esses "pacotes" de folhas, reduzindo sua concentração nas áreas visitadas.

Dentre as variáveis descritoras da estrutura de comunidades aplicadas para macroinvertebrados bentônicos, riqueza e índice de diversidade taxonômica atingiram a pontuação mínima nos três grupos de empreendimentos, enquanto densidade de organismos não obteve pontuação nos grupos (Tabela 11). Novamente, a distinção entre os pontos de impacto e controle foi verificada apenas para balneários (Figuras, 25, 27 e 29 e Tabela 11), resultado da maior interferência da visitação pública nos trechos do rio em que se desenvolvem esses empreendimentos. Riqueza e índice de diversidade taxonômica exibiram alta correlação linear em todos os grupos de empreendimentos $(p<0,05)$, indicando que bastaria selecionar uma dessas variáveis como indicadora do impacto sobre os macroinvertebrados bentônicos. Dentre estas, riqueza seria teoricamente mais simples, uma vez que deve, obrigatoriamente, ser previamente analisada para se compor o índice de diversidade (PIELOU, 1977). Entretanto, uma vez obtido os valores de riqueza, o esforço adicional para se obter o índice de diversidade é insignificante, o que na prática justifica a adoção de ambas as variáveis como indicadoras de impacto.

Ressalta-se que a abordagem taxonômica em nível de família deve ser considerada como o mínimo necessário no emprego de macroinvertebrados bentônicos como indicadores de impactos da visitação pública em ecossistemas aquáticos. 
Avaliações ambientais considerando esse nível taxonômico podem mascarar informações importantes sobre os ecossistemas avaliados. Análises futuras, comparando respostas de diferentes níveis taxonômicos, são necessárias para se conhecer a viabilidade de abordagens mais refinadas em programas de monitoramento ambiental na região.

Tabela 11. Seleção de indicadores de impactos da visitação pública a partir da análise das variáveis descritoras da estrutura de comunidades obtidas para os macroinvertebrados bentônicos considerando os três grupos de empreendimentos estudados, conforme critérios apresentados no item 2.5.

\begin{tabular}{|c|c|c|c|c|c|c|c|c|}
\hline 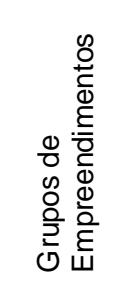 & Variáveis & 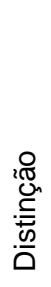 & $\begin{array}{l}\frac{0}{0} \\
\frac{\pi}{0} \\
. \frac{0}{0} \\
\frac{\pi}{5} \\
\frac{0}{0} \\
\simeq\end{array}$ & 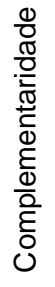 & 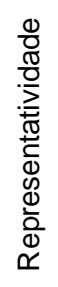 & 号 & $\begin{array}{l}\frac{0}{0} \\
\frac{\pi}{0} \\
\frac{0}{0} \\
\frac{0}{\pi} \\
0\end{array}$ & $\begin{array}{l}\frac{\pi}{0} \\
\frac{c}{c 0} \\
\frac{c}{t} \\
\frac{0}{0} \\
\underline{E}\end{array}$ \\
\hline \multirow{3}{*}{ 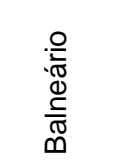 } & Riqueza & 5 & 4 & 3 & 5 & 3 & 2 & 22 \\
\hline & Abundância & & & & & & & \\
\hline & Índice de diversidade & 5 & 5 & 3 & 5 & 3 & 2 & 23 \\
\hline \multirow{3}{*}{ 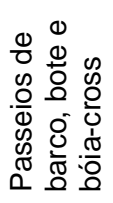 } & Riqueza & & 4 & 3 & 5 & 3 & 2 & 17 \\
\hline & Abundância & & & & & & & \\
\hline & Índice de diversidade & & 4 & 3 & 5 & 3 & 2 & 17 \\
\hline \multirow{3}{*}{ 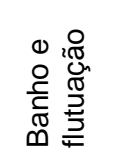 } & Riqueza & 5 & 5 & 3 & 5 & 3 & 2 & 23 \\
\hline & Abundância & & & & & & & \\
\hline & Índice de diversidade & & 5 & 3 & 5 & 3 & 2 & 18 \\
\hline
\end{tabular}

O fato da abundância de organismos não ter evidenciado os impactos da visitação, nem mesmo nos balneários, pode estar relacionado ao nível de identificação taxonômica adotado. Se os organismos fossem identificados até o nível de espécie, talvez as diferenças de densidades ficassem mais evidentes entre os pontos impacto e controle. Em um estudo realizado em uma região de nascentes visitada por turistas no Death Valley National Park, Califórnia, EUA, enfocando-se uma espécie de molusco (Assiminea infima), comprovou-se que o macroinvertebrado teve sua abundância negativamente afetada pelo pisoteio dos visitantes (SADA, 2001).

As respostas exibidas pelos macroinvertebrados bentônicos aos impactos da visitação pública podem ser resultado tanto do efeito direto do pisoteio quanto da 
desestruturação e simplificação do substrato de fundo. De acordo com Minshall (1984), Hynes (1970) e Richardson (1992), existe uma forte relação entre a riqueza de macroinvertebrados e a estrutura e composição do substrato, de forma que quanto maior a riqueza e disponibilidade de texturas granulométricas grossas, especialmente de origem orgânica, maior a riqueza de organismos. De maneira geral, a simplificação do ambiente leva à simplificação da biota. Isso pode ocorrer pela redução na disponibilidade de refúgios, alimentos ou ambos.

O efeito negativo da ação mecânica das pessoas sobre as estruturas do sedimento e da comunidade bentônica foi evidenciado por Bervian, Medina-Jr e Roque (2007), em trabalho realizado em um trecho do rio Formoso (mesmo ecossistema avaliado no presente estudo). Através de uma abordagem experimental, os autores verificaram que a movimentação da água e o pisoteio do fundo promovem a ressuspensão e deriva tanto de folhedo quanto de invertebrados bentônicos.

As diferentes variáveis empregadas na avaliação da integridade física de ecossistemas e na geração do IAEFE descrevem condições de componentes ambientais específicos, sendo, portanto, complementares. Além disso, todas exibiram regularidade na resposta ao impacto, são de baixo custo e de aplicação bastante prática. Devido à essas características e à importância e aplicabilidade das informações geradas por essas variáveis para a gestão das áreas visitadas, todas foram consideradas potenciais indicadoras para se avaliar e monitorar os impactos da visitação pública nos três grupos de empreendimentos estudados. Esse conjunto de variáveis deve ser considerado como o mínimo necessário para se avaliar as condições físicas dos ecossistemas visitados.

A importância do emprego de variáveis descritoras das condições qualitativas do meio cresceu nas últimas décadas. Diversos trabalhos abordam a adaptação e aplicação de protocolos de avaliação da estrutura física de ecossistemas no reconhecimento e monitoramento de ecossistemas aquáticos continentais (RANKIN, 1989, PLAFKIN et al., 1989; HANNAFORD et al., 1997; HALL et al., 1999; BARBOUR et al., 1999; CALLISTO et al., 2002; CASATI, 2003). 
O IAEFE forneceu uma visão sintética das condições da estrutura física dos ecossistemas, evidenciando os maiores índices de alteração nos trechos do rio onde se desenvolvem atividades com maior grau de contato do visitante com o meio - balneários e banho e flutuação (Figura 32). Entretanto, a alta discrepância verificada nos valores do IAEFE nas diferentes estações de coleta para os três grupos de estações, refletiu certamente a grande variação nos valores das variáveis adotadas. Dessa forma, é recomendável que, adicionalmente à interpretação do IAEFE, se efetue sempre uma análise individualizada das respostas das variáveis que o compuseram. Isso garantiria ao gestor respostas complementares sobre as condições do ecossistema avaliado.

A padronização do IAEFE, com valores variando de 0 a 100, por exemplo, como recomendado por Rufino (2002), poderia torná-lo uma ferramenta mais aplicável ao monitoramento das condições aceitáveis das áreas visitadas, pois facilitaria comparações. O gestor teria informações mais claras do quanto as condições do local estão próximas ou distantes do aceitável.

De maneira geral, o pisoteio do fundo e a movimentação da água foram as interferências mais determinantes nas alterações ambientais provocadas pela visitação pública no rio Formoso. Quanto maior o grau dessas interferências, mais nítida a resposta nos compartimentos analisados, de forma que as variáveis abióticas do sedimento e os macroinvertebrados bentônicos respondem mais prontamente ao impacto, enquanto as variáveis abióticas da água respondem secundariamente aos impactos impressos no sedimento. Além disso, o sedimento, os macroinvertebrados bentônicos e o IAEFE apresentam a propriedade de armazenar informações ao longo de uma escala temporal, enquanto a água reflete apenas os impactos momentâneos (McCARTHY \& SHUGART, 1990; LENAT \& BARBOUR, 1994; ALBA-TERCEDOR, 1996; HANNAFORD et al., 1997; BARBOUR et. al., 1999; CALLISTO, MORETTI, GOULART, 2001; SOUZA, 2001; CALLISTO et al, 2002). Pode-se assumir, então, que os efeitos crônicos são mais apropriadamente acessados através dos primeiros, enquanto a água responde mais apropriadamente aos efeitos agudos no sistema, o que torna os 
compartimentos complementares em uma análise global. Dessa forma, o emprego de indicadores que representem os diferentes compartimentos é indispensável para se acessar informações sobre a distribuição, intensidade, e dimensão temporal dos impactos da visitação pública no rio Formoso.

Considerando-se os critérios adotados de seleção, as variáveis transparência da água, folhedo, riqueza e diversidade taxonômica e IAEFE, incluindo as variáveis que compõem o referido índice, integram um conjunto adequado de indicadores para se avaliar e monitorar os impactos da visitação pública no rio Formoso. Apesar da transparência da água ter sido selecionada apenas para balneários, é recomendável que, pelo princípio da precaução, também seja incluída como indicadora para os demais grupos de empreendimentos, tendo em vista seu baixo custo e praticidade de aplicação, além da possibilidade de responder a alterações momentâneas no ambiente.

Essas variáveis selecionadas são boas candidatas para compor um sistema regional de monitoramento da visitação pública, podendo ser empregadas por técnicos de nível médio, desde que treinados. Adicionalmente, são de baixo custo, relacionam-se diretamente ao uso público e podem responder ao manejo nas condições de uso, características recomendadas para indicadores serem incluídos em programas de monitoramento e manejo de uso público em áreas naturais, conforme estudos de Graefe (1990), Krumpe (2000) e Manning (2000). 


\section{Conclusões e recomendações}

1. Cerca de $1 / 3$ de todos os empreendimentos turísticos rurais registrados em órgãos oficiais do Mato Grosso do Sul encontra-se instalado na região do Planalto da Bodoquena. Destes, 80,3\% concentra-se no município de Bonito. Ficou evidente, portanto, a importância da região para a atividade turística no estado e a necessidade de implementação de políticas voltadas ao desenvolvimento de outros pólos de turismo e à diversificação dos destinos no próprio Planalto da Bodoquena, como estratégia para reduzir a pressão ali concentrada, especificamente no município de Bonito;

2. É patente a falta de preocupação com a gestão ambiental dos empreendimentos de turismo instalados no Planalto da Bodoquena, tendo em vista que menos de $50 \%$ destes estão operando com licença ambiental. A conscientização dos empreendedores e usuários e a efetiva responsabilização do poder público pela proteção dos recursos naturais enquanto bem comum é uma necessidade iminente;

3. Os ecossistemas aquáticos são os principais atrativos visitados no Planalto da Bodoquena e são os atrativos naturais com a maior demanda de exploração por parte dos empreendimentos instalados na região $(66,6 \%)$. A grande maioria dos visitantes entrevistados ao longo do rio Formoso (78,4\%) apontou algum tipo de atividade nos ecossistemas aquáticos como a principal desenvolvida por eles durante a visita a Bonito. Essas informações, associadas ao escasso conhecimento científico sobre os ecossistemas aquáticos da região e a biodiversidade por eles suportada, evidenciam a urgência de se implementar estratégias voltadas à proteção e exploração racional desses ecossistemas; 
4. Ficou evidente, através de algumas variáveis descritoras das condições abióticas da água e do sedimento e da abundância de macroinvertebrados bentônicos, que em determinadas situações as variações espaciais nas condições ambientais são mais proeminentes que as variações entre os pontos de impacto e controle. Estudos com maior número de repetições, envolvendo os diferentes grupos de empreendimentos e incluindo a abordagem experimental poderão fornecer importantes respostas sobre os fatores naturais que podem interferir nas respostas da condições ambientais aos efeitos da visitação, potencializando ou minimizando as alterações;

5. O presente estudo demonstra a pouca efetividade dos programas de monitoramento de impactos da visitação pública em ecossistemas aquáticos no estado de Mato Grosso do Sul, uma vez que estes estão baseados nas variáveis classicamente empregadas na avaliação de qualidade da água como temperatura, $\mathrm{pH}$, oxigênio dissolvido, condutividade elétrica e nutrientes. Essas variáveis foram as menos efetivas na distinção dos impactos da visitação pública no rio Formoso e, provavelmente, tal incoerência se repita para outros estados brasileiros;

6. De maneira geral, os balneários exibiram os maiores níveis de impacto em todos os compartimentos analisados, evidenciando que a movimentação da água e o pisoteio do fundo são as interferências da visitação pública mais pronunciadas sobre o rio Formoso. Essas atividades também são as que mais concentram visitantes por trecho de rio utilizado, retêm o visitante por mais tempo em atividade no local, apresentam os maiores graus de ocupação da barranca e da mata ribeirinha e possuem baixa capacidade em desviar a concentração de visitantes do ambiente aquático. Os balneários somam, portanto, o maior conjunto de características impactantes dentre os empreendimentos de visitação pública instalados no rio Formoso; 
7. Os visitantes dos balneários exibiram o menor grau de exigência ambiental sendo que os comportamentos de saltar no rio e deixar lixo fora da lixeira receberam o maior e menor grau de importância por parte dos visitantes em geral. De maneira geral, as áreas mais impactadas recebem os visitantes com menos exigência ambiental;

8. O Índice de Alteração da Estrutura Física de Ecossistemas (IAEFE) mostrou-se uma importante ferramenta na avaliação de impactos da visitação pública no rio Formoso, uma vez que destaca alterações no ecossistema que não seriam evidenciadas através de variáveis classicamente empregadas em monitoramentos de ecossistemas aquáticos. O refinamento e validação de protocolos de avaliação qualitativa aplicado aos ecossistemas da região é indispensável para a implementação de programas de monitoramento e gestão das áreas naturais visitadas;

9. O conjunto de indicadores selecionados como mais aplicáveis à avaliação e monitoramento dos impactos da visitação pública no rio Formoso inclui a transparência da água, folhedo, riqueza e diversidade taxonômica de macroinvertebrados, além do IAEFE. Essas variáveis foram selecionadas a partir de uma análise dos padrões globais de alterações impressas pelos empreendimentos instalados ao longo do rio Formoso e as diferentes atividades neles desenvolvidas. Cada empreendimento apresentou uma ou outra peculiaridade, as quais poderiam ser exploradas com maior profundidade futuramente, caso se pretenda analisar os impactos enfocando os empreendimentos individualmente; 
10. Além de atenderem aos critérios técnicos de regularidade, complementaridade, representatividade, baixo custo e praticidade, todos os indicadores selecionados são diretamente relacionados ao uso público e podem responder ao manejo nas condições de uso, condições desejáveis para aplicação na gestão do uso público em áreas naturais. A partir desses indicadores e dos dados obtidos para o perfil e exigência ambiental do visitante, pode se conduzir estudos visando ao estabelecimento das condições naturais mínimas aceitáveis (padrões para os indicadores de impacto) e à elaboração de campanhas de conduta consciente na visitação aos ecossistemas aquáticos do Planalto da Bodoquena;

11. Infelizmente, não foi possível estabelecer um paralelo entre os impactos da visitação pública no rio Formoso e os de outras localidades, devido à escassez de estudos sobre essa temática em ecossistemas aquáticos continentais. Os estudos relacionados à visitação pública em ambientes aquáticos são ainda incipientes e estão voltados principalmente para ecossistemas marinhos. Isso demonstra, dentre outros aspectos, a importância de estudos como os desenvolvidos no presente trabalho para se ampliar os conhecimentos científicos sobre a visitação pública em áreas naturais e, ao mesmo tempo, produzir informações de aplicação prática à gestão ambiental dessas áreas. Apesar dos ecossistemas aquáticos continentais serem os atrativos naturais mais requeridos pelo uso público, estes têm sido os mais negligenciados com respeito a estudos técnico-científicos em áreas naturais sujeitas à visitação. 


\section{Referências bibliográficas}

Ab'Saber, A. N. Diretrizes para uma política de preservação de reservas naturais no Estado de São Paulo Geografia e Planejamento, 30: São Paulo, USP, 1977. 1-27.

ALBA-TERCEDOR, J...Macroinvertebrados acuáticos y calidad de las aguas de los rios. IV SIAGA, Almeria, II: 1996, 203-213.

ALMEIDA-JUNIOR, J.M.G. Por uma ordem mundial. In: Cadernos Aslegis. Brasília, v 1(1), 1997. p. 2-30.

ALTVATER, E. O preço da riqueza. São Paulo: UNESP. 1995, 184p.

ANDERSON, D. R. SWENEY, D. J; WILLIANS, T. A. Estatística aplicada a administração e economia. Trad. Luiz Sérgio de Castro Paiva. São Paulo: Pioneira, 2002. 450p.

APHA (American Public. Health Association). Standard methods: for examination of water and wast water. 14 ed., Washington, APHA, 1998. 1268p.

ARAUJO, H.J.T.; SANTOS-NETO, A.; TRINDADE, C.A.H.; PINTO,J.C.A.; MONTALVÃO, R.M.G.; DOURADO, T.D.C.; PALMEIRA, R. C. B.; TASSINARI,C.C.G. Folha SF-21: Campo Grande, 1 - Geologia. Projeto Radambrasil. Ministério das Minas e Energia. Departamento Nacional de Produção Mineral (Levantamento de Recursos Naturais). Rio de Janeiro, 1982.v.28. p. 9-124.

ARCHER, B. \& COOPER, C. Os impactos positivos e negativos do turismo. In: THEOBALD, W.F. (Org.). Turismo Global. Tradução: Anna Maria Capovilla; Maria Cristina Guimarães Cupertino; João Ricardo Barros Penteado. São Paulo: SENAC, São Paulo, 2001. p.95-102.

BARBOUR, M. T.J.,GERRITSEN, B.D., SNYDER, AND J. B. STRIBLING, J. B. Rapid bioassessment protocols for use in streams and wadeable rivers: periphyton, 
benthic macroinvertebrates and fish. 2. ed. EPA 841-B-99-002, US, Washington: Environmental Protection Agency, Office of Water, 1999.

BERTUGA-CERQUEIRA, M. Variação da comunidade de macroalgas ao longo de um trecho impactado do rio Bonito, município de Descalvado, estado de São Paulo, e sua relação com as variáveis físicas, químicas e biológicas. São Carlos, 1999. 73p. Tese (Doutorado) - Universidade Federal de São Carlos.

Bervian, C. I. B.; Medina Jr; P. B.; Roque, F. de O. Efeito do pisoteio e movimentação de visitantes na deriva de macroinvertebrados e detritos no rio Formoso (Bonito, Mato Grosso do Sul, Brasil): evidências experimentais. Bioinformação, 2006. UNIDERP: Campo Grande.

BESCHTA, R.L. Suspend sediment and bedload In: HAUER, F. R. \& LAMBERTI, G. A. (ed) Methods in stream Ecology. San Diego Academic Press. San Diego. 1996. p. 123143.

BOGGIANI, P.C. Geologia da Bodoquena. In: SCREMIN-DIAS, E. et al.Nos jardins submersos da Bodoquena: guia para identificação de plantas aquáticas de Bonito e região. Campo Grande: Universidade Federal de Mato Grosso do Sul, 1999. p.10-23.

BOGGIANI, P.C.;GONDA,J.\& IDE,C.N. Proposta de preservação da Bacia do Rio Formoso através da criação de APA e monitoramento de suas águas superficiais e subterrâneas. Campo Grande: ABES, 1998.

BONTEMPO, M. Analise sócio-econômica do turismo ecológico no Brasil: um estudo de caso. Viçosa, 1994. Dissertação (mestrado em Economia Rural) Universidade Federal de Viçosa.

BOO, E. O planejamento ecoturístico para áreas protegidas.In: LINDBERG, K. \& HAWKINS, D.E. (Org.). Ecoturismo: um guia para planejamento e gestão. 4. ed. São Paulo: Senac, 2002. p.33-55.

BOO, E. Ecotorism: potentials and pitfalls. Qashington, D.C.:Wildlife Fund., 1990.v.1. 
BONITO, MS. Prefeitura Municipal de Bonito. Resolução Normativa no 001/95, de 14 de novembro de 1995. Bonito, 1995.

BOUCHARD, R.W., Jr. Guide to aquatic macroinvertebrates of the Upper Midwest. Water Resouces Center, Univerty of Minenesota, St Paul. 2004. 208p.

BRANDON, K. Etapas básicas para incentivar a participação local em projetos de turismo de natureza. In: LINDBERG, K. \& HAWKINS, D. E. (Eds) Ecoturismo: um guia para planejamento e gestão. 4. ed. São Paulo: Senac, 1995. p.225-256.

BRASIL. Ministério do Esporte e Turismo. Pólos de ecoturismo: Brasil (compact disc). Brasília: Ministério do Esporte e Turismo; EMBRATUR; IEB; 2001.

BRASIL. MMA. Ações prioritárias para a conservação da biodiversidade do Cerrado e do Pantanal. Workshop do Cerrado e do Pantanal, MMA/ Funatura/ Cl/ Biodiverditas, Brasília, D.F., 1999. 26p.

BRASIL. Projeto de lei no 2892, de 1992. Mensagem no 176, de 20 de maio de 1992. dispõe sobre os objetivos nacionais de conservação da natureza, cria o Sistema Nacional de Unidades de Conservação, estabelece medidas de preservação da diversidade biológica e dá outras providencias. Brasília, Presidência da Republica. 4p.

BRASIL. Workshop "Políticas de Unidades de Conservação", Brasília, 29 nov. a 02 dez. 1994. Documentos. MMA/Comissão de Defesa do Consumidor, Meio Ambiente e Minorias, Anexo II; Brasília, 1994 a.

BRINKHURST, R. O. \& M. R. MARCHESE. Guia de la identificacion de Oligoquetos acuaticos continentales de Sud y Centroamerica. Associación Ciencias Naturales del Litoral. Argentina. Colección Climax (5), 1989. 207p.

CALlisto, M.; FERREIRA, W. R.; MORENO, P.; GOULART, M.; PETRUCiO, M. Aplicação de um protocolo de avaliação rápida diversidade de habitats em atividades de ensino e pesquisa (MG - RJ). Acta Limnol. Bras., v.14, n.1, p.91-98, 2002. 
CALLISTO, M.; MORETTI, M. \& GOULART, M. Macroinvertebrados Bentônicos como Ferramentas para Avaliar a Saúde de Riachos. Revista Brasileira de Recursos Hídricos. Volume 6 n. ${ }^{\circ}$, jan/ mar 2001, p.71-82.4

CAPELAS JUNIOR, A. Grandes viagens, grandes imagens. Os Caminhos da Terra. A.4, n.5, Ed.37, mai.1995.

CASATTI, L. Avaliação da integridade biótica dos riachos da região noroeste do Estado de São Paulo, bacia do Alto Paraná, utilizando comunidades de peixes. Universidade Estadual Paulista, Instituto de biociências, Letras e Ciência Exatas, Departamento de Zoologia e Botânica, 2003. 105p. No prelo.

CEBALLOS-LASCURÁIN, H. O ecoturismo como fenômeno mundial. In: LINDBERG, K. e HAWKINS, D. E. (Eds). Ecoturismo: um guia para planejamento de gestão. São Paulo: Senac. p.16-22. Ciências Agrárias, Universidade Federal do Paraná, 1995. 128p.

CEBALLOS-LASCURÁIN, H. Tourim, ecotourism and protected áreas: te state of nature-based tourism around the world and guidelines for its development. IUCNThe orld Conservation Union: Gland, Switzerland, and Cambridge, UK1, 1996.

CIFUENTES, M. A. Determinación de capacidad de carga turística en áreas protegidas. CATIE. Programa de Manejo Integrado de Recursos Naturales. Serie técnica. Informe Técnico. 1992, N.194. 28p.

CLARK, R. \& STANKEY, G. The recreation opportunity spectrum: a framework for planning, management and research, General Technical Report. Seattle: US Department of Agriculture, 1979.

COLE, D.N.; BAYFIELD, N.G. Recrational trampling of vegetation: standard experimental procedures. Biological Conservation, v. 63, 1993. p.209-15.

COLE, D.N. Changes on trails in the Selway-Bitterroot Wilderness, Montana, 1978-89. USDA, Forest Service. Intermountain Research Station. Research Paper INT-450, 1991. $5 p$. 
COLE, D.N. Recreational Trampling Experiments: Effects of trampler weight and shoe type. USDA. Forest Service. Intermountain research Station. Research Not INT-RN-425, 1995. $4 p$.

COLE, D.N. Wilderness recreation use trends, 1965 through 1994. Research Paper INT. USDA. Forest Service, Ogden, n. 488, 1996. p. 1-11.

CORSON, W. H. Manual global de ecologia: O que você pode fazer a respeito da crise do meio ambiente. 2 ed, São Paulo, Augustus, 1996. 413p.

CHRISTOFOLETTI, A., 1981. Geomorfologia Fluvial. Edgard Blucher. São Paulo. 313p.

DE PAUW, N. \& VANHOOREN, G. Method for biological assesment of water course in Belgium. Hidrobiologia. v. 100, 1983. p.153-168.

DENCKER, A. F. \& VIÁ, S. C. Pesquisa empírica em ciências humanas. São Paulo: Futura, 2002. 225p.

DENCKER, A.F.M. Métodos e técnicas de pesquisa em turismo. São Paulo: Futura. $1998,286 p$.

DIEGUES, A.C. O mito da natureza intocada. São Paulo: Hucitec, 1996.

DIKMAN, M., and M, DORAIS. The Impact of Human Trampling on Phosphorus Loading to a Small Lake in Gatineau Park, Quebec. Canada. Journal of Environmental Management. 1977. 5: p.335-344.

DOMINGOS, M. D. Limnologia do rio Betari (Iporanga, SP) e a relação com o estado de conservação de sua bacia hidrográfica-subsídios para o desenvolvimento sustentável. São Carlos, 2002. 272p. Tese (Doutorado) - Escola de Engenharia de São Carlos, Universidade de São Paulo.

DOUROJEANNI, M.J. \& PADUA, M.T.J. Biodiversidade: a hora decisiva. Curitiba: UFPR, 2001, 308p. 
EMBRATUR - Instituto Brasileiro de Turismo. Pólos de ecoturismo Sul/Centro Oeste. EMBRATUR/IEB - Instituto de Ecoturismo do Brasil, 1999.

EMBRATUR. Diretrizes do programa Nacional de municipalização do turismo. Brasilia, 1998.

EMBRATUR. Diretrizes para uma Política Nacional do Ecoturismo. Brasília: EMBRATUR. 1994, 45p.

FENNELL, D.A. Ecotourism in Canadá, Annals of Tourism Research. v.25(1), 1998. p.231-234.

FENNELL, D.A. Ecoturismo. Tradução de Inês Lohbauer. São Paulo: Contexto, 2002. $281 \mathrm{p}$.

FERREIRA, P. S. Uso de espécies de Odonata como indicadores de alteração ambiental. Dissertação (Mestrado). Viçosa: Universidade Federal de Viçosa, 1998. 33p. FONSECA, J.S. da \& MARTINS, G. de A. Curso de Estatística. 4aㅡ edição. Atlas, São Paulo, 1994.

FREIXÊDAS-VIEIRA, V. M.; PASSOLD, A. J.; MAGRO, T.C. Impactos do uso público: um guia de campo para utilização do método. In: CONGRESSO BRASILEIRO DE UNIDADES DE CONSERVAÇÃO, 2., 2000, Campo Grande. Anais. Campo Grande: Rede Nacional Pró Unidade de Conservação e Fundacão O Boticário de Proteção à Natureza, 2000. p.296-305.

GARMS, A. et al. Turismo. Aspectos sócio-economicos da Bacia do Alto Paraguai em Mato Grosso do Sul. In: Plano de Conservação da Bacia do Alto Paraguai-PCBAP. Brasília: Ministério do Meio Ambiente, dos Recursos Hídricos e da Amazônia Legal, 1997. GARY, H. I. 1982. Stream water quality in a smal commercial campground in Colorado. Journal of Environmental Healt, v. 45, n. 1, p. 5-12. 1982. 
GIONGO, F., BOSCO-NIZEYE, J. AND WALLACE, G.N. (1994) A Study of Visitor Management in the World's National Parks and Protected Areas. College of Natural Resources, Colorado State University, Ecotourism Society, and International Union for the Conservation of Nature. Disponível em http//www.ecotoursm.org/parksfr.html, acessado em janeiro 2007.

GOLTERMAN, H. L; CLYMO, R. S.; OHNSTAND, M. A. Methods for physical and chemical analysis of fresh water. Oxford, Blackwel Scientific Publicatios, (IPB Handbook, n.8). 1978, 213p.

GOODWIN, $\mathrm{H}$. In pursuit of ecotourism. Diponivel em: http://www.buckscol.ac.uk/leisure/tourfor/home.htm Acesso em 13 de dez. 1998p.

GRAEFE, A.R.; KUSS, F.R.; VASKE, J.J. Visitor Impact management: the planning framework. Washington: National Park and Conservation Association, 1990. 105p.

GUERESCHI, R. M. Monitoramento biológico de três córregos na estação ecológica do Jataí, Luíz Antônio, SP. São Carlos, 1999. 117p. Dissertação (Mestrado) - UFScar Universidade Federal de São Carlos.

HALL JR, L. W.; MORGAN, R.P.; PERRY, E.S. \& WALTZ, A. Development of a provisional physical habitat index for Maryland freshwater streams. Annapolis, Maryland, CNWP-MANTA-EA-99-12: Maryland Departament of Natural Resources, Monitoring and Non-Tidal Assessment Division, 1999.

HAMMIT, W.; COLE, D. N. Wildland recreation: ecology and management. 2.ed. New York: John Wiley, 1998. 361p.

HANNAFORD, M.J.; BARBOUR, M.T.; RESH, V.H. Training reduces observer variability in visual - based assessments of stream habitat. J. N. Am. Benthol. Soc., v.16, n.4, 1997. p.853-860.

HAYNES, H. B. N. The Ecology of Running Waters. University of Toronto, 1970. 55p. 
IBGE. Instituto Brasileiro de Geografia e Estatística - IBGE Cidades: Mato Grosso do Sul. Disponível em: <http://www.ibge.gov.br/cidadesat/default.php>. Acesso em: $20 / 05 / 2007$

IUCN/Unep/WWF. Estratégia Mundial para a Conservação: a conservação dos recursos vivos para um desenvolvimento sustentado. Cesp, São Paulo, 1984.

JOHN, D. M. \& JOHNSON, L. R. Green microphytic algae as river Water quality monitors. In: WHITTON, B. A., ROTT, E., FRIEDRICH, G. (eds.) Use of algae for monitoring rivers, 1991. p.41-47.

KERLINGER, F. N. Metodologia da pesquisa em ciências sociais: um tratamento conceitual. Tradução: Helena Mendes Rotundo. São Paulo: EPU: Editora da Universidade de São Paulo. 1980, 441p.

HUECK, K. \& P. SEIBERT.. Vegetationskarte von Südamerika. Band Ila. Fischer, Sttutgart, $1981.90 \mathrm{pp}$.

KUSS, F.R.; GRAEFE, A.R.; VASKE, J.J. Visitor impact management. Washington, 1990.

LIDDLE, M.J. Recreation and the environment: The ecology of recreation impacts. Section 2. Vegetation and wear. School of Australian Environmental Studies. Griffth University. AES Working Paper 1/88. 1988, 189p.

JIM, C. Y. Visitor management in recreation areas. Environmental conservation, vol. 16, 1, Spring, 1989. p.19-40

KEMP, J. L.; HARPER, D. M.; CROSA, G. A. The habitat-sacale ecohydraulics of rivers. Ecological Engeneering 16. 2000. p.17-29.

KRUMPE, E.E. The role of science in wilderness planning: a state-of-knowledge review. In: WILDERNESS SCIENCE IN A TIME OF CHANGE CONFERENCE: WILDERNESS VISITORS, EXPERIENCES, AND VISITOR MANAGEMENT, 4., Missoula, 1999. Proceedings. Missoula: USDA, Forest Service, 2000. p.134-141. 
LITVIN,S.W. "Ecotourism: a study of purchase proclivity". Journal of Vacation

Marketing. 1996.3 (1): p.43-54.

LOWE-McCONNELL, R. H. Estudos ecológicos de comunidades de peixes tropicais. Trad. Anna Emília A. de M. Vazzoler; Angelo Antônio Agostinho, Patrícia T. M. Cunnhingham. ed. EDUSP - São Paulo: (Coleção Base) 1999. 535p.

MAGRO, T.C. Impactos ambientais de projetos e turismo rural. In: OLIVEIRA, C.G.S.; MOURA, J.C.; SGAI, M. Turismo no espaço rural brasileiro. Piracicaba: FEALQ. 2001. p.76-89.

MAGRO, T.C. Impactos do uso público em uma trilha no planalto do Parque Nacional do Itatiaia. São Carlos, 1999. 135p. Tese (Doutorado) - Escola de Engenharia de São Carlos, Universidade de São Paulo.

MAGRO, T.C. OlIVEIRA, A. E.; LOBATO, R.S. (Org.) Manejo do uso público: contribuições para o plano de manejo do Parque Estadual da Serrra do Mar Núcleo São Sebastião. Piracicaba: USP-ESALQ, 2001. 65 p. Relatório técnico.

MANNING, R.E.; LIME, D.W. Defining and managing the quality of wilderness recreation experiences. In: WILDERNESS SCIENCE IN A TIME OF CHANGE CONFERENCE: WILDERNESS VISITORS, EXPERIENCES, AND VISITOR MANAGEMENT, 4., Missoula, 1999. Proceedings, Missoula: USDA, Forest Service, 2000. MARTINS, G, A. Estatística geral e aplicada. São Paulo: Atlas, 1999. 281p.

MEYBECK, M. 1982. Carbon, nitrogen, and phosphorus transport by world rivers. American Journal of Science $282(4):$ p.401-450.

MERRITT, R. W. \& CUMMINS, K. W. 1996. An introduction to aquatic insects of North America. Kendall/Hunt Publ. Co. 1996, 826p.

MINSHALL, G.W. Aquatic insect-substratum relationships, pp. 358-400. In V. H. Resh \& D. M. Rosenberg (eds), The ecology of aquatic insects. Praeger, New York. 1984 
McCAFFERTY, W. P. Aquatic Entomology; the fishermen's and ecologist's. Illustred guide to insects and their relatives. Jones \& Bartlett Publ., Inc. Boston, 1981. 448p.

McCARTHY, J.F.; SHUGART, L.R. Bilogical makers of environmental contamination. In: Biomarkers of environmental contamination. Chelsea, MI, Lewis Publisshers. 1990.

McCOOL, S.F. Limits of acceptable change: A framework for managing national protected areas: experiences from the United States. Paper presented at Workshop on Impact Management in Marine Parks, Maritime Institute of Malaysia, August 13-14, Kuala Lumpur, Malaysia. 1996.

MCKERCHER, B. Turismo de natureza: planejamento e sustentabilidade. (Tradução Beth Honorato) - São Paulo: Contexto, 2002.

MOLINA, E. S. Turismo y ecologia. 6. ed. México: Trilhas. 2000. 92p.

MORETTI, E.C. $O$ ideário da sociedade ocidente sobre a natureza e o conceito de “Desenvolvimento sustentável”, Revista de Geografia, Campo Grande: UFMS, nํ3, 1996.

MS NOTÍCIAS. Ibama interdita 14 passeios em Bonito a pedido do MPE. Disponível em: <http://www.msnoticias.com.br>. Capturado em out. 2007

NECCHI, O. Jr. BRANCO, C. C. Z.; SIMÃO, R.C. G.; BRANCO, L. H. Z. Distribution of stream macroalgae in the northwestet region of São Paulo State, southeastern Brazil. Hidrobiologia, v. 299, 1995. p.219-230.

NECCHI, O. Jr. BRANCO, L. H. Z. DIP, M. R. Uso de macroalgas para avaliação da poluição orgânica no rio Preto, noroeste do estado de São Paulo. An. Acad. Brás. Ci., v. 66. n. 3, p.231-252. 1994.

OENNING, K. Qualidade física-química e microbiológica da água proveniente do Balneário Municipal Rio Formoso-Bonito/MS. Campo Grande, 2003. 56p. 
OSEMEOBO, G.J. (1989) Forest recreational land-use and zoological gardens in a developing economy: the case of Southern Nigeria. Environmental Conservation, 16(1): p.69-74.

PCBAP - Plano de conservação da Bacia do Alto Paraguai/Projeto Pantanal. Programa Nacional do Meio Ambiente. Brasília: PNMA, 1997, 3vol.,em 7 t.

PIELOU, E.C. Mathematical Ecology. New York: Wiley, 1977. 385p.

PIRES, P.S. Ecoturismo no Brasil: uma abordagem histórica e conceitual na perspectiva ambientalista. São Paulo, 1998. 217 p. Tese (Doutorado) - FFLCH, Universidade de São Paulo.

PÉREZ, G.R. Guia para el estudio de los macroinvertebrados acuáticos del Departamento de Antioquia, Colômbia, Bogotá. Editorial Presencia Ltda. 1989, 217p.

PLAFKIN, J. L.; BARBOUR, M. T.; PORTER, K. D.; GROSS, S. K. \& HUGHES, R. M., 1989. Rapid Bioassessment Protocols for use in Streams and Rivers: Benthic Macroinvertebrates and Fish. Washington, DC: Environmental Protection Agency.

QUEIROZ, O.T.M.M. Atividades Turísticas e Recursos Naturais In: Turismo e ambiente: temas emergentes. Campinas, SP:Editora Alínea, 2006.p.76-109.

RICHARDSON, D. H. S. ed. Biological indicators of pollution. Dublin, Royal Irish Academy, 1987. 242p.

RIBEIRO, R. Bonito demais. Os Caminhos da Terra. a.5, n.5, Ed.49, mai.1996.

RICHARDSON, A.M.M. 1992. Altitudinal distribution of native and alien landhoppers (Amphipoda: Talitridae) in the Ko'olau Range, O'ahu, Hawaiian Islands. Journal of Natural History, London, 26: p.339-352.

RIO FORMOSO. Projeto de gestão integrada da bacia hidrográfica do Rio Formoso, 2007. Disponível em: <http://www.gefrioformoso.org.br/plataforma/imagens/bacia1.gif> Acesso em: jun. 2007. 
ROBIM, M.J. Análise das características do uso recreativo do Parque Estadual da Ilha Anchieta: Uma contribuição manejo. 1999. Tese (Doutorado) - Centro de Ciências de Pós graduação em Ecologia e Recursos Naturais, Universidade Federal de São Carlos, (UFSCar)

ROQUE, F.O. \& TRIVINHO-STRIXINO, S. Fragmentação de habitat nos córregos do Parque Estadual do Jaraguá (SP): possíveis impactos na riqueza de macroinvertebrados e considerações para a conservação in situ. In: II Congresso Brasileiro de Unidades de Conservação. Anais. Campo Grande: Rede Nacional Pró-Unidades de Conservação: Fundação O Boticário de Proteção à Natureza, 2000. 3v.

RUFINO, R.C. Avaliação da qualidade ambiental do município de Tubarão (sc) através do uso de indicadores Ambientais. 2002. Dissertação (Mestrado) Programa de Pós-Graduação em Engenharia de Produção. Universidade Federal de Santa Catarina. $113 \mathrm{p}$.

RUSCHMANN, D. Turismo e planejamento sustentável: proteção do meio ambiente. 2. ed. Papirus, 1999.

SABINO, J. \& ANDRADE, L. P. Uso e conservação da ictiofauna no ecoturismo da região de bonito, Mato Grosso do Sul: o mito da sustentabilidade ecológica no rio baía bonita (aquário natural de bonito). Biota Neotrópica, v.3, n2, 2003. Disponível em: ttp://www.biotaneotropica.org.br/v3n2.

SABINO, J. \& ANDRADE, L.P. Monitoramento e consenvação no rio Baía Bonita, região de Bonito, Mato Grosso do Sul, Brasil. Pp. 397-404. In: Anais do III Congresso Brasileiro de Unidades de Conservação. Rede Pró-Unidades de Conservação, Fundação Boticário e Proteção à Natureza e Associação Caatinga. Fortaleza, Ceará. 876p.11: 543-547. 2002.

SABINO, J.; MEDINA JR, P. B. ; ANDRADE, L. P. Visitantes mal-comportados e piraputangas obesas: a pressão da visitação pública sobre Brycon hilarii no 
Balneário Municipal de Bonito, Mato Grosso do Sul, Brasil. In: III Encontro Nacional de Pesquisa e Iniciação Científica, 2005, Campo Grande. IV Encontro Nacional de Pesquisa e Iniciação Científica. Campo Grande : Editora da UNIDERP, 2005. v. 1. p.321332

SANDEVILE- JR, E. A paisagem natural tropical e sua apropriação para o turismo. In: YÁZIGI, E. (Org.) Turismo e paisagem. São Paulo: Contexto, 2002. p.141-50.

SANTANA, P.V. Ecoturismo: uma indústria sem chaminé. Dissertação: mestrado. FFLCH -USP, 1998.

SCHIAVETTI, A. Aspectos da estrutura, funcionamento e manejo da reserva particular do patrimônio natural "Ecoparque de Uma": região cacaueira do Sul da Bahia, Brasil. Tese (Doutorado) - Unviversidade Federal de São Carlos: UFSCar, 2003 SERRANO, C.M.T. O produto ecoturístico. In: ANSARAH, M.G.R. (Org.). Turismo: Como aprender, como ensinar. São Paulo: Senac, 2001. p.203-234.

SADA, D.W. Demography and habitat use of the Badwater snail (Assiminea infima), with observations on its conservation status, Death Valley National Park, California, U.S.A. Hydrobiologia 466, 2001. p.255-265.

SERRANO, C.M.T.; LUCHIARE, M.T. Desenvolvimento, desenvolvimento sustentável e suas críticas. In: RODRIGUES, A.M. Meio Ambiente: Ecos da Eco. Campinas: IFCHUNICAMP, 1993.

SERRANO,C.; BRUNS, H. (Org.) Viagens à Natureza: Turismo, Cultura e Ambiente. Campinas: Papirus, 1997, 150p.

SILVERMAN, G. \& ERMAN, D.C. Alpine Lakes in Kings Canyon National Park, California: Baseline Conditions and Possible Effects of Visitor Use. Journal of Environmental Management, 1979. p.73-87.

SNUC - Sistema Nacional de Unidades de Conservação da Natureza: Lei n 9.9985, 18 de julho de 2000. Brasília: MMA/SBF, 2002, 52p. 
SOUZA, P. A. P. A importância do uso de bioindicadores de qualidade: o caso específico das águas. In: FELICIDADE, N.; MARTINS, R. C.; LEME, A. A. Uso e gestão dos recursos hídricos no Brasil. São Carlos: RIMA, 2001. p.55-66.

SPANDAU, L. Angewandte ökosystemforschung im Nationalpark Berchtesgaden. Nationalparkverwaltung Berchtesgaden, Forschungsbericht, 1994, 88p.

STANKEY, G. H.; COLE, D.N.; LUCAS, R.C. et al. The limits of Acceptable Change (LAC) System for Wilderness Planning. USDA. Forest Service. Intermountain Forest and Range Experimental Station. General Technical Report. INT-176, 1985. p. 1-37.

SWARBROOKE, J. Turismo sustentável: conceitos e impacto ambiental. V. 1. Trad. Margarete Dias Pulido. São Paulo: Aleph, 2000. 140p.

SZARO, R. C.; JOHNSTON, D.W. Biodiversity in managed landscapes. Theory and practice. Oxford University Press, 1996. 778p.

TAKAHASHI, L.Y. Avaliação da visitação e dos recursos recreativos da Estrada da Graciosa. Curitiba, 1987. Dissertação (Mestrado em Ciências Florestais) - Setor de Ciências Agrárias, Universidade Federal do Paraná.

TAKAHASHI, L.Y. Caracterização dos visitantes, suas preferências e percepções e avaliação dos impactos da visitação publica em duas unidades de conservação do Paraná. Curitiba, 1998. 129p. Tese (Doutorado) - Setor de Ciências Agrárias, Universidade Federal do Paraná.

TAYLOR, T.P. \& ERMAN, D.C. The Littoral Bottom Fauna of High Elevation Lakes in Kings Canyon National Park. California Fish and Game, 1980. p.112-119.

TAYLOR, T.P. \& ERMAN, D.C. The Response of Benthic Plants to Past Levels of Human Use in High Mountain Lakes in Kings Canyon National Park, California. Journal of Environmental Management. v.9, 1979. p.271-278. 
TEIXEIRA, C.; TUNDISI, J. G.; KUTNER, M B. Plankton studies in a mangrave enviroment II. The standing stok and some ecological factors. B. Inst. Oceanogr., USP, v. 24, 1965. p.23-41.

THOMPSON, P. "The errant e-word: putting ecotourism back on track", Explore, 1995. 73:67-72.

TRIVINHO-STRIXINO, S \& STRIXINO, G. Larvas de Chironomidae do Estado de São Paulo. Guia de identificação e diagnose dos gêneros. São Carlos: PPG-ERN/UFSCar, 1995. 229p.

WAGAR, J. A. The carrying capacity of wildlands for recreation. Washington: D. C. Society of American Foresters. Forest Science Monograph, n. 7, 1964. 24p.

WALLACE, G. N. A administração do visitante: lições do Parque Nacional de Galápagos. In: LINDBERG, K. \& HAWKINS, D. E. (Eds.) Ecoturismo: um guia para planejamento e gestão. São Paulo: Senac, 1995. p.95-142.

WALLACE, G.N. A administração do visitante: licões do Parque Nacional de Galápagos. In: LINDBERG, K. \& HAWKINS, D.E. (Org.). Ecoturismo: um guia para planejamento e gestão. 4ed. São Paulo: Senac, 2002. p.94-139.

WATSON, A.E. et al. Visitor characteristics and preferences for three national forest, 1992.

WILSON, A. The Culture of Nature, Cambridge, MA: Blackwell. 1992.

WEARING, S.; NEIL, J. Ecoturismo: Impactos, Potencialidades e Possibilidades. São Paulo: Manole Ltda, 2001. 256p.

WETZEL, R. G. \& LIKENS, G. E. Limnological analysis. 2 ed. New York, W. B. Saunders Company, 1991. 391p.

WORLD TURISM ORGANIATION. Guia de desenvolvimento do turismo sustentável. Tradução: Sandra Netz. São Paulo: Bookman, 2003. 168p. 
WORLD TURISM ORGANIATION. Third united conference on the least developed countries, international trade, commodities and services. http://www.worldtourism.org/newsrom/speeches/more_speeches/S0105010.html.2003 (09 set 2003).

WORLD TOURISM ORGANIZATION. Picks hot tourism trends for 21st century. FrancescoFrangiolli.http://www.worldtourism.org/pressre/LISBON.html.1998 (20 out 2001) 



\section{ANEXOS}

Anexo 1. Questionário aplicado para avaliar as características da visita e características e preferência ambiental dos visitantes.

ESTE QUESTIONÁRIO FAZ PARTE DE UMA PESQUISA SOBRE A VISITAÇÃO
PÚBLICA NO RIO FORMOSO PARA SUBSIDIAR UM GERENCIAMENTO ADEQUADO
DO LOCAL.
PODEMOS CONTAR COM SUA COLABORAÇÃO?

Local:

Data:

1

1. Com que freqüência visita Bonito?

( ) 1ํㅗ vez ( )Até 3 vezes ao ano ( ) Até 6 vezes ao ano ( ) Mais de 6 vezes ao ano

2. Quanto tempo pretende permanecer em Bonito?

( )1 dia ( ) 2 dias ( ) 3 dias ( ) até 7dias ( ) Mais de 10 dias

3. Quais atividades você realiza em Bonito?

( ) Acampa ( ) Pratica esportes fora d'água (vôo livre, cavalgada, mountain bike, etc)

( ) Visita cavernas ( ) Mergulha com cilindro ( ) Pratica flutuação ( ) Nada/toma banho de rio ( ) Aprecia a paisagem ( ) Pratica esportes na água (bote, bóia-cross, outros)

4. Qual destas atividades você considera a principal? 
5. Quanto tempo pretende permanecer neste(a) $?$ (Balneário camping, hotel,

ousada,

passeio)

( ) Até meio dia ( ) o dia todo ( ) 2 dias ( ) 3 dias ( ) Até 7 dias ( ) Mais de 3 dias

6. Com que freqüência visita este (a) ? (Balneário, camping, hotel , pousada, passeio)

( ) primeira vez ( )Toda vez que vem a Bonito ( ) Quase todas as vezes que a vem a Bonito ( ) Algumas das vezes que vem a Bonito

7. Qual a principal atividade realizada por você neste(a) ? (Balneário, camping, hotel, ousada, passeio)

8. Tamanho do grupo:

( ) Está sozinho ( ) 2 a 4 pessoas ( ) 5 a 10 pessoas ( ) Mais de 10 pessoas

9.Grau de escolaridade:

( ) $1^{\circ}$ grau incompleto ( ) $1^{\circ}$ grau completo ( ) $2^{\circ}$ grau incompleto ( ) $2^{\circ}$ grau completo

( ) Cursando ensino superior ( ) Ensino superior completo ( ) Pós-graduado

10. Local de residência:

Cidade: Estado: País:

11. Idade:

( ) 10 a 15 ( ) 15 a 20 ( ) 20 a 30 ( ) 30 a 40 ( ) 40 a 50 ( ) mais de 50

12. Gênero: ( ) Masculino ( ) Feminino 
13. Sua renda familiar em $R \$$ é de:

( ) menos de 250 ( ) 250 a 500 ( ) 500 a 1000 ( ) 1000 a 2000 ( ) 2000 a 5000 ( ) mais de 5000

14. Quanto você gasta em média por dia em Bonito ( $R \$)$ ?

( ) menos de 50 ( ) 50 a 100 ( ) 100 a 200 ( ) 200 a 300 ( ) 300 a 500 ( ) 500 a1000

( ) mais de 1000

15. O que você faz com o lixo que produz?

( ) deixa no local onde está ( ) deposita na lixeira ( ) não produz lixo

16. Para você:

\begin{tabular}{|l|l|l|l|}
\hline \multicolumn{1}{|c|}{ TIPO DE AÇÃo } & $\begin{array}{c}\text { Não } \\
\text { causa } \\
\text { impacto }\end{array}$ & $\begin{array}{c}\text { Causa } \\
\text { pouco } \\
\text { impacto }\end{array}$ & $\begin{array}{c}\text { Causa } \\
\text { muito } \\
\text { impacto }\end{array}$ \\
\hline 1. Saltar no rio & & & \\
\hline 2. Retirar a vegetação ou outro material do fundo do rio & & & \\
\hline 3. Entrar na água usando protetor solar, bronzeador ou & & & \\
hidratante & & & \\
\hline 5. Tocar o fundo do rio com os pés & & & \\
\hline 6. Subir ou deslizar sobre as tufas calcárias ("cachoeiras") & & & \\
\hline 7. Deixar lixo fora das lixeiras & & & \\
\hline 8. Pisar sobre pequenas plantas na margem do rio & & & \\
\hline 9. Abrir trilhas na margem do rio & & & \\
\hline 10. Som alto & & & \\
\hline
\end{tabular}





\begin{tabular}{|c|c|c|c|c|c|c|c|c|c|c|c|c|c|c|}
\hline \multirow[b]{2}{*}{ Estação } & \multirow[b]{2}{*}{ Empr. } & \multicolumn{13}{|c|}{ Atividades desenvolvidas } \\
\hline & & 焉 & & 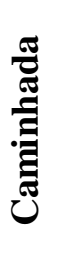 & 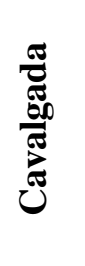 & 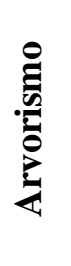 & 总 & 忍 & 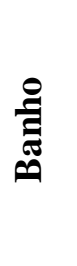 & 异 & 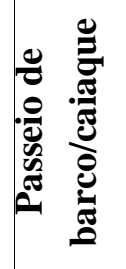 & 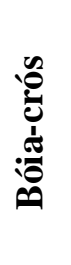 & 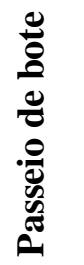 & $\stackrel{\mathscr{E}}{E}$ \\
\hline $\bar{A}$ & $\bar{A}$ & & & + & & & & $\mathrm{x}^{\mathrm{pP}}$ & $x$ & & & & & + \\
\hline B & B & & & + & & & - & & & $\mathrm{pe}^{\mathrm{pe}}$ & $\mathbf{x}^{\mathrm{pr}}$ & & & - \\
\hline \multirow[t]{2}{*}{ C } & $\mathrm{Cl}$ & & & $t$ & - & & $\mathrm{x}$ & $\mathrm{x}^{\mathrm{pP}}$ & $\mathrm{x}$ & & & & & - \\
\hline & $\mathrm{C2}$ & & & $t$ & & & $\mathrm{x}$ & $\mathrm{x}^{\mathrm{pP}}$ & $\mathrm{x}$ & & & & & + \\
\hline $\bar{D}$ & D & & & + & & & & $\mathrm{x}$ & $\mathrm{x}$ & $\mathbf{x}^{\mathrm{pp}}$ & & & & to \\
\hline $\bar{E}$ & $\mathrm{E}$ & - & & + & & & $\mathrm{x}$ & $\mathrm{x}$ & $\mathrm{x}$ & & & $\mathbf{X}^{\mathrm{pp}}$ & & - \\
\hline$F$ & $F$ & & to & + & & & & $\mathrm{x}$ & $\mathrm{x}$ & $\mathbf{x}^{\mathrm{pp}}$ & & & & - \\
\hline G & G & & & + & & $t^{p e}$ & & & $x$ & $\mathrm{x}^{\mathrm{pr}}$ & & & & \\
\hline$\overline{\mathrm{H}}$ & $\mathrm{H}$ & & & + & - & & & & $\mathrm{x}$ & $\mathbf{x}^{\mathrm{pp}}$ & & & & - \\
\hline I & I & $t^{\mathrm{pe}}$ & & to & • & & & & $\mathbf{x}^{\mathrm{pr}}$ & & $\mathrm{x}$ & & & + \\
\hline $\mathrm{J}$ & $\mathrm{J}$ & & & + & & & & & $x$ & & & & $\mathbf{x}^{\mathrm{pp}}$ & \\
\hline $\mathrm{L}$ & $\bar{L}$ & - & & + & - & & & & $x$ & & & & $\mathbf{x}^{\mathrm{Pp}}$ & - \\
\hline $\mathrm{M}$ & $\mathrm{M}$ & - & & + & - & & & & $\mathrm{X}$ & & & & $\mathbf{x}^{\mathrm{pp}}$ & + \\
\hline $\mathrm{N}$ & $\mathrm{N}$ & & & + & & & & & $\mathrm{x}^{\mathrm{pP}}$ & $x$ & & & $\mathrm{x}$ & + \\
\hline 0 & 0 & & + & & & & & & $x$ & $\mathrm{x}^{\mathrm{pp}}$ & & & & + \\
\hline$P$ & $P$ & $\mathrm{pet}^{\mathrm{pe}}$ & & to & - & & & & $\mathrm{x}^{\mathrm{pr}}$ & & & & $\mathrm{x}$ & - \\
\hline & & 5 & 2 & 14 & 6 & 1 & 4 & 6 & 15 & 6 & 2 & 1 & 5 & 14 \\
\hline Frequiên & atividades & 31,2 & 12,5 & 87,5 & 37,5 & 6,2 & 25,0 & 37,5 & 93,7 & 37,5 & 12,5 & 6,2 & 31,2 & 87,5 \\
\hline
\end{tabular}

Anexo 2. Atividades desenvolvidas pelos empreendimentos estudados

x: no rio; t: na APP; $\bullet$ : fora da APP; to: parte na APP e parte fora da APP

pe: principal atividade no empreendimento; pr: principal atividade no rio; pp: principal atividade no empreendimento e no rio

Outros: prática de esportes com bola, jogos de mesa, descanso em área de convivência, lanchonetelrestaurante ou bares 


\begin{tabular}{|c|c|c|c|c|c|c|c|c|c|c|}
\hline \multirow[t]{2}{*}{ Estação } & \multirow[t]{2}{*}{ Empr. } & \multicolumn{2}{|c|}{ Principal atividade } & \multicolumn{2}{|c|}{$\begin{array}{l}\text { Uso do rio e sua } \\
\text { zona ribeirinha } \\
\text { (m) }\end{array}$} & \multirow{2}{*}{$\begin{array}{l}\text { Ocupação da } \\
\text { barranca } \\
\text { (m) }\end{array}$} & \multicolumn{3}{|c|}{$\begin{array}{l}\text { Ocupação da mata ribeirinha } \\
\qquad(\mathrm{m})\end{array}$} & \multirow[t]{2}{*}{$\begin{array}{c}\text { Capacidade em desviar a } \\
\text { concentração de visitantes do } \\
\text { ambiente aquático }\end{array}$} \\
\hline & & $\begin{array}{c}\text { No } \\
\text { empreendimento }\end{array}$ & No rio & $\begin{array}{l}\text { Zona } \\
\text { ribeirinh }\end{array}$ & Rio & & I & Ml & $\mathrm{El}$ & \\
\hline A & $\bar{A}$ & Flutuação & Flutuação & 400 & 300 & 24 & 340 & 15 & 45 & Alta \\
\hline $\bar{B}$ & $\bar{B}$ & Balneário em lago & Passeio de barco & 800 & 800 & 9 & 7770 & 30 & - & Alta \\
\hline \multirow[t]{2}{*}{ C } & $\mathrm{C1}$ & Flutuação & Flutuação & 3000 & 3000 & 27 & 3000 & - & & Alta \\
\hline & C2 & Flutuação & Flutuação & 2000 & 2000 & 30 & 2000 & - & 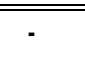 & Alta \\
\hline $\bar{D}$ & $\bar{D}$ & Balneário & Balneário & 300 & 300 & 179 & 80 & 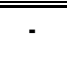 & 220 & Baixa \\
\hline $\bar{E}$ & $\bar{E}$ & Bóia-crós & Bóia-crós & 2000 & 1000 & 39 & 2000 & - & - & Alta \\
\hline $\bar{F}$ & $\bar{F}$ & Balneário & Balneário & 420 & 3330 & 154 & 380 & - & 60 & Baixa \\
\hline $\bar{G}$ & $\bar{G}$ & Arvorismo & Balneário & 80 & 30 & 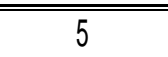 & 80 & - & - & Alta \\
\hline 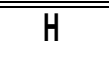 & 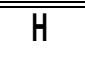 & Balneário & Balneário & 290 & 155 & 203 & - & 255 & 235 & Baixa \\
\hline $\bar{I}$ & $\bar{I}$ & Hospedagem & Banho & 1200 & 2000 & 56 & 1120 & - & 80 & Alta \\
\hline $\bar{J}$ & $\bar{J}$ & Bote & Bote & 300 & 7000 & 220 & 210 & - & 90 & Baixa \\
\hline 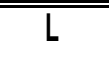 & 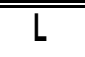 & Bote & Bote & 150 & " 6500 & 42 & 80 & 30 & 40 & Baixa \\
\hline$\overline{\bar{M}}$ & $\bar{M}$ & Bote & Bote & 150 & 6000 & $\overline{18}$ & 42 & - & 8 & Média \\
\hline$\overline{N N}$ & $\overline{N \mathrm{~N}}$ & Banho & Banho & 1000 & 700 & 79 & - & 440 & 560 & Baixa \\
\hline$\overline{0}$ & $\overline{0}$ & Balneário & Balneário & 80 & 40 & 13 & - & - & 80 & Baixa \\
\hline $\bar{P}$ & $\bar{P}$ & Hospedagem & Banho & 250 & 500 & 3 & 210 & - & 10 & Alta \\
\hline
\end{tabular}

Anexo 3. Descritores da estrutura e funcionamento dos empreendimentos de turismo inseridos nas estações de amostragem 
Anexo 4. Quadros-síntese das características da visita e dos visitantes nos empreendimentos de turismo estudados ao longo do rio Formoso

Anexo 4.1. Frequiência em que o visitante visita o lugar x estação de amostragem

\begin{tabular}{|c|c|c|c|c|c|c|c|c|c|c|c|c|c|c|c|c|}
\hline \multirow{2}{*}{ Frequência de visita } & \multicolumn{16}{|c|}{ Estações de amostragem } \\
\hline & $A$ & B & $\mathrm{Cl}$ & C2 & D & $E$ & $F$ & $G$ & $H$ & I & $\mathrm{J}$ & $L$ & M & N & 0 & $P$ \\
\hline Primeira vez & $100 \%$ & 20,6 & $80,0 \%$ & $100 \%$ & $10,0 \%$ & $87,5 \%$ & $25,0 \%$ & $100 \%$ & $20,0 \%$ & $25,0 \%$ & $81,8 \%$ & $76,8 \%$ & $57,1 \%$ & $22,7 \%$ & $22,2 \%$ & $14,3 \%$ \\
\hline $\begin{array}{c}\text { Toda vez que vem a } \\
\text { Bonito }\end{array}$ & $0,0 \%$ & $61,5 \%$ & $0,0 \%$ & $0,0 \%$ & $68,2 \%$ & $0,0 \%$ & $50,0 \%$ & $0,0 \%$ & $60,0 \%$ & $0,0 \%$ & $9,0 \%$ & $15,4 \%$ & $0,0 \%$ & $6,8 \%$ & $66,6 \%$ & $57,1 \%$ \\
\hline $\begin{array}{c}\text { Quase todas as vezes que } \\
\text { vem a Bonito }\end{array}$ & $0,0 \%$ & $7,1 \%$ & $0,0 \%$ & $0,0 \%$ & $13,6 \%$ & $6,25 \%$ & $25,0 \%$ & $0,0 \%$ & $15,0 \%$ & $0,0 \%$ & $9,0 \%$ & $0,0 \%$ & $0,0 \%$ & $6,8 \%$ & $0,0 \%$ & $14,3 \%$ \\
\hline $\begin{array}{c}\text { Algumas das vezes que } \\
\text { vem a Bonito }\end{array}$ & $0,0 \%$ & $10,7 \%$ & $20,0 \%$ & $0,0 \%$ & $8,2 \%$ & $6,25 \%$ & $0,0 \%$ & $0,0 \%$ & $5,0 \%$ & $75,5 \%$ & $50,0 \%$ & $7,7 \%$ & $42,8 \%$ & $50,0 \%$ & $1,11 \%$ & $14,3 \%$ \\
\hline Não pretende retornar & $0,0 \%$ & $0,0 \%$ & $0,0 \%$ & $33,3 \%$ & $0,0 \%$ & $0,0 \%$ & $0,0 \%$ & $0,0 \%$ & $0,0 \%$ & $25,5 \%$ & $0,0 \%$ & $0,0 \%$ & $0,0 \%$ & $13,7 \%$ & $0,0 \%$ & $0,0 \%$ \\
\hline Total & $100 \%$ & $100 \%$ & $100 \%$ & $100 \%$ & $100 \%$ & $100 \%$ & $100 \%$ & $100 \%$ & $100 \%$ & $100 \%$ & $100 \%$ & $100 \%$ & $100 \%$ & $100 \%$ & $100 \%$ & $100 \%$ \\
\hline
\end{tabular}



Anexo 4.2. Tempo de permanência no local x estação de amostragem

\begin{tabular}{|c|c|c|c|c|c|c|c|c|c|c|c|c|c|c|c|c|}
\hline \multirow{2}{*}{$\begin{array}{l}\text { Tempo de } \\
\text { permanência }\end{array}$} & \multicolumn{16}{|c|}{ Estação de amostragem } \\
\hline & A & B & C1 & C2 & D & $E$ & $F$ & G & $H$ & I & $J$ & $L$ & M & $\mathrm{N}$ & 0 & $P$ \\
\hline Até o meio dia & $100 \%$ & $0,0 \%$ & $60,0 \%$ & $68,4 \%$ & $0,0 \%$ & $50,0 \%$ & $0,0 \%$ & $0,0 \%$ & $5,0 \%$ & $0,0 \%$ & $36,4 \%$ & $38,5 \%$ & $28,6 \%$ & $34,9 \%$ & $0,0 \%$ & $0,0 \%$ \\
\hline 0 dia todo & $0,0 \%$ & $85,3 \%$ & $20,0 \%$ & $26,3 \%$ & $49,3 \%$ & $31,3 \%$ & $9,1 \%$ & $100 \%$ & $75,0 \%$ & $0,0 \%$ & $54,5 \%$ & $53,8 \%$ & $0,0 \%$ & $58,1 \%$ & $11,1 \%$ & $0,0 \%$ \\
\hline 2 dias & $0,0 \%$ & $0,0 \%$ & $0,0 \%$ & $0,0 \%$ & $1,4 \%$ & $0,0 \%$ & $0,0 \%$ & $0,0 \%$ & $15,0 \%$ & $0,0 \%$ & $9,1 \%$ & $7,7 \%$ & $0,0 \%$ & $0,0 \%$ & $0,0 \%$ & $71,4 \%$ \\
\hline 3 dias & $0,0 \%$ & $8,8 \%$ & $0,0 \%$ & $0,0 \%$ & $16,4 \%$ & $6,3 \%$ & $27,3 \%$ & $0,0 \%$ & $0,0 \%$ & $50,0 \%$ & $0,0 \%$ & $0,0 \%$ & $57,1 \%$ & $4,7 \%$ & $44,4 \%$ & $14,3 \%$ \\
\hline Até 7 dias & $0,0 \%$ & $5,9 \%$ & $20,0 \%$ & $5,3 \%$ & $32,2 \%$ & $12,5 \%$ & $63,6 \%$ & $0,0 \%$ & $5,0 \%$ & $50,0 \%$ & $0,0 \%$ & $0,0 \%$ & $14,3 \%$ & $2,3 \%$ & $44,4 \%$ & $14,3 \%$ \\
\hline Mais de 7 dias & $0,0 \%$ & $0,0 \%$ & $0,0 \%$ & $0,0 \%$ & $0,7 \%$ & $0,0 \%$ & $0,0 \%$ & $0,0 \%$ & $0,0 \%$ & $0,0 \%$ & $0,0 \%$ & $0,0 \%$ & $0,0 \%$ & $0,0 \%$ & $0,0 \%$ & $0,0 \%$ \\
\hline Total & $100 \%$ & $100 \%$ & $100 \%$ & $100 \%$ & $100 \%$ & $100 \%$ & $100 \%$ & $100 \%$ & $100 \%$ & $100 \%$ & $100 \%$ & $100 \%$ & $100 \%$ & $100 \%$ & $100 \%$ & $100 \%$ \\
\hline
\end{tabular}


Anexo 4.3. Tamanho do grupo de viagem x estação de amostragem

\begin{tabular}{|c|c|c|c|c|c|c|c|c|c|c|c|c|c|c|c|c|}
\hline \multirow{2}{*}{$\begin{array}{c}\text { Tamanho do } \\
\text { grupo }\end{array}$} & \multicolumn{16}{|c|}{ Estação de amostragem } \\
\hline & A & B & $\mathrm{Cl}$ & C2 & $D$ & E & $F$ & $G$ & $H$ & I & $\mathrm{J}$ & L & M & N & 0 & $P$ \\
\hline Está sozinho & $0,0 \%$ & $0,0 \%$ & $20,0 \%$ & $10,5 \%$ & $2,8 \%$ & $0,0 \%$ & $0,0 \%$ & $0,0 \%$ & $0,0 \%$ & $0,0 \%$ & $18,2 \%$ & $0,0 \%$ & $14,3 \%$ & $0,0 \%$ & $0,0 \%$ & $0,0 \%$ \\
\hline 2 a 4 pessoas & $66,7 \%$ & $50,0 \%$ & $70,0 \%$ & $47,4 \%$ & $40,0 \%$ & $68,8 \%$ & $33,3 \%$ & $66,7 \%$ & $20,0 \%$ & $75,0 \%$ & $54,5 \%$ & $71,4 \%$ & $71,4 \%$ & $34,1 \%$ & $33,3 \%$ & $85,7 \%$ \\
\hline $\begin{array}{l}5 \text { a } 10 \\
\text { pessoas }\end{array}$ & $33,3 \%$ & $47,1 \%$ & $10,0 \%$ & $42,1 \%$ & $45,5 \%$ & $12,5 \%$ & $58,3 \%$ & $33,3 \%$ & $45,0 \%$ & $25,0 \%$ & $18,2 \%$ & $7,1 \%$ & $0,0 \%$ & $34,1 \%$ & $22,2 \%$ & $14,3 \%$ \\
\hline $\begin{array}{l}\text { Mais de } 10 \\
\text { pessoas }\end{array}$ & $0,0 \%$ & $2,9 \%$ & $0,0 \%$ & $0,0 \%$ & $11,7 \%$ & $18,8 \%$ & $8,3 \%$ & $0,0 \%$ & $35,0 \%$ & $0,0 \%$ & $9,1 \%$ & $21,4 \%$ & $14,3 \%$ & $31,8 \%$ & $44,4 \%$ & $0,0 \%$ \\
\hline Total & $100 \%$ & $100 \%$ & $100 \%$ & $100 \%$ & $100 \%$ & $100 \%$ & $100 \%$ & $100 \%$ & $100 \%$ & $100 \%$ & $100 \%$ & $100 \%$ & $100 \%$ & $100 \%$ & $100 \%$ & $100 \%$ \\
\hline
\end{tabular}




\section{Anexo 4.4. Atividade considerada como principal $x$ estação de amostragem}

\begin{tabular}{|c|c|c|c|c|c|c|c|c|c|c|c|c|c|c|c|c|}
\hline \multirow{2}{*}{ ividade } & \multicolumn{16}{|c|}{ Estação de amostragem } \\
\hline & $A$ & $B$ & $\mathrm{Cl}$ & C2 & $D$ & $E$ & $F$ & $G$ & $\mathrm{H}$ & I & $J$ & $L$ & M & $\mathrm{N}$ & 0 & $P$ \\
\hline Nadar & $12,5 \%$ & $100 \%$ & $11,1 \%$ & $0,0 \%$ & $78,6 \%$ & $0,0 \%$ & $75,0 \%$ & $0,0 \%$ & $84,2 \%$ & $75,0 \%$ & $0,0 \%$ & $0,0 \%$ & $42,9 \%$ & $61,4 \%$ & $22,2 \%$ & $28,6 \%$ \\
\hline Acampar & $0,0 \%$ & $0,0 \%$ & $0,0 \%$ & $0,0 \%$ & $13,6 \%$ & $0,0 \%$ & $25,0 \%$ & $0,0 \%$ & $0,0 \%$ & $0,0 \%$ & $0,0 \%$ & $0,0 \%$ & $0,0 \%$ & $0,0 \%$ & $22,2 \%$ & $0,0 \%$ \\
\hline Várias & $0,0 \%$ & $0,0 \%$ & $11,1 \%$ & $5,6 \%$ & $6,4 \%$ & $0,0 \%$ & $0,0 \%$ & $0,0 \%$ & $10,5 \%$ & $0,0 \%$ & $9,1 \%$ & $21,4 \%$ & $0,0 \%$ & $25,0 \%$ & $44,4 \%$ & $14,3 \%$ \\
\hline Apreciar a paisagem & $0,0 \%$ & $0,0 \%$ & $0,0 \%$ & $0,0 \%$ & $1,4 \%$ & $0,0 \%$ & $0,0 \%$ & $0,0 \%$ & $5,3 \%$ & $0,0 \%$ & $0,0 \%$ & $0,0 \%$ & $0,0 \%$ & $6,8 \%$ & $11,1 \%$ & $42,9 \%$ \\
\hline Esportes na água & $0,0 \%$ & $0,0 \%$ & $0,0 \%$ & $22,2 \%$ & $0,0 \%$ & $100 \%$ & $0,0 \%$ & $0,0 \%$ & $0,0 \%$ & $0,0 \%$ & $90,9 \%$ & $78,6 \%$ & $57,1 \%$ & $4,5 \%$ & $0,0 \%$ & $14,3 \%$ \\
\hline Mergulhar com cilindro & $0,0 \%$ & $0,0 \%$ & $22,2 \%$ & $5,6 \%$ & $0,0 \%$ & $0,0 \%$ & $0,0 \%$ & $0,0 \%$ & $0,0 \%$ & $0,0 \%$ & $0,0 \%$ & $0,0 \%$ & $0,0 \%$ & $2,3 \%$ & $0,0 \%$ & $0,0 \%$ \\
\hline Flutuação & $87,5 \%$ & $0,0 \%$ & $55,6 \%$ & $61,1 \%$ & $0,0 \%$ & $0,0 \%$ & $0,0 \%$ & $0,0 \%$ & $0,0 \%$ & $25,0 \%$ & $0,0 \%$ & $0,0 \%$ & $0,0 \%$ & $0,0 \%$ & $0,0 \%$ & $0,0 \%$ \\
\hline Esportes fora da água & $0,0 \%$ & $0,0 \%$ & $0,0 \%$ & $5,6 \%$ & $0,0 \%$ & $0,0 \%$ & $0,0 \%$ & $100 \%$ & $0,0 \%$ & $0,0 \%$ & $0,0 \%$ & $0,0 \%$ & $0,0 \%$ & $0,0 \%$ & $0,0 \%$ & $0,0 \%$ \\
\hline Total & $100 \%$ & $100 \%$ & $100 \%$ & $100 \%$ & $100 \%$ & $100 \%$ & $100 \%$ & $100 \%$ & $100 \%$ & $100 \%$ & $100 \%$ & $100 \%$ & $100 \%$ & $100 \%$ & $100 \%$ & $100 \%$ \\
\hline Esportes fora da água & $0,0 \%$ & $0,0 \%$ & $0,0 \%$ & $0,0 \%$ & $0,0 \%$ & $0,0 \%$ & $0,0 \%$ & $33,3 \%$ & $0,0 \%$ & $0,0 \%$ & $0,0 \%$ & $0,0 \%$ & $0,0 \%$ & $0,0 \%$ & $0,0 \%$ & $0,0 \%$ \\
\hline Total & $100 \%$ & $100 \%$ & $100 \%$ & $100 \%$ & $100 \%$ & $100 \%$ & $100 \%$ & $100 \%$ & $100 \%$ & $100 \%$ & $100 \%$ & $100 \%$ & $100 \%$ & $100 \%$ & $100 \%$ & $100 \%$ \\
\hline
\end{tabular}


Anexo 4.5. Faixa etáría dos visitantes $x$ estação de amostragem

\begin{tabular}{|c|c|c|c|c|c|c|c|c|c|c|c|c|c|c|c|c|}
\hline \multirow{2}{*}{ Faixa etária } & \multicolumn{16}{|c|}{ Estações de amostragem } \\
\hline & A & B & $\mathrm{C1}$ & C2 & D & E & $F$ & $G$ & $H$ & I & J & $L$ & M & N & 0 & $P$ \\
\hline 10 a 15 anos & $0,0 \%$ & $0,0 \%$ & $0,0 \%$ & $0,0 \%$ & $0,0 \%$ & $0,0 \%$ & $0,0 \%$ & $0,0 \%$ & $0,0 \%$ & $0,0 \%$ & $0,0 \%$ & $0,0 \%$ & $0,0 \%$ & $2,3 \%$ & $0,0 \%$ & $0,0 \%$ \\
\hline 15 a 20 anos & $0,0 \%$ & $0,0 \%$ & $0,0 \%$ & $10,5 \%$ & $4,9 \%$ & $0,0 \%$ & $0,0 \%$ & $0,0 \%$ & $5,0 \%$ & $0,0 \%$ & $0,0 \%$ & $0,0 \%$ & $0,0 \%$ & $18,2 \%$ & $0,0 \%$ & $0,0 \%$ \\
\hline 20 a 30 anos & $50,0 \%$ & $26,5 \%$ & $30,0 \%$ & $47,4 \%$ & $66,0 \%$ & $62,5 \%$ & $58,3 \%$ & $66,7 \%$ & $55,0 \%$ & $0,0 \%$ & $9,1 \%$ & $7,7 \%$ & $57,1 \%$ & $43,2 \%$ & $66,7 \%$ & $14,3 \%$ \\
\hline 30 a 40 anos & $0,0 \%$ & $50,0 \%$ & $40,0 \%$ & $21,1 \%$ & $21,5 \%$ & $25,0 \%$ & $25,0 \%$ & $33,3 \%$ & $25,0 \%$ & $50,0 \%$ & $72,7 \%$ & $61,5 \%$ & $14,3 \%$ & $11,4 \%$ & $0,0 \%$ & $42,9 \%$ \\
\hline 40 a 50 anos & $25,0 \%$ & $17,6 \%$ & $20,0 \%$ & $10,5 \%$ & $6,3 \%$ & $12,5 \%$ & $16,7 \%$ & $0,0 \%$ & $15,0 \%$ & $50,0 \%$ & $9,1 \%$ & $30,8 \%$ & $28,6 \%$ & $18,2 \%$ & $22,2 \%$ & $28,6 \%$ \\
\hline $\begin{array}{l}\text { mais de } 50 \\
\text { anos }\end{array}$ & $25,0 \%$ & $5,9 \%$ & $10,0 \%$ & $10,5 \%$ & $1,4 \%$ & $0,0 \%$ & $0,0 \%$ & $0,0 \%$ & $0,0 \%$ & $0,0 \%$ & $9,1 \%$ & $0,0 \%$ & $0,0 \%$ & 6,8\% & $11,1 \%$ & $14,3 \%$ \\
\hline Total & $100 \%$ & $100 \%$ & $100 \%$ & $100 \%$ & $100 \%$ & $100 \%$ & $100 \%$ & $100 \%$ & $100 \%$ & $100 \%$ & $100 \%$ & $100 \%$ & $100 \%$ & $100 \%$ & $100 \%$ & $100 \%$ \\
\hline
\end{tabular}




\section{Anexo 4.6. Grau de escolaridade do visitante x estação de amostragem}

\begin{tabular}{|c|c|c|c|c|c|c|c|c|c|c|c|c|c|c|c|c|}
\hline \multirow{2}{*}{ Escolaridade } & \multicolumn{16}{|c|}{ Estações de amostragem } \\
\hline & $A$ & B & $\mathrm{Cl}$ & C2 & D & $E$ & $F$ & $G$ & $H$ & I & $J$ & L & M & N & 0 & $P$ \\
\hline $\begin{array}{l}10 \text { grau } \\
\text { imcompleto }\end{array}$ & $0,0 \%$ & $0,0 \%$ & $0,0 \%$ & $0,0 \%$ & $1,4 \%$ & $6,3 \%$ & $0,0 \%$ & $0,0 \%$ & $0,0 \%$ & $0,0 \%$ & $0,0 \%$ & $0,0 \%$ & $0,0 \%$ & $4,5 \%$ & $11,1 \%$ & $0,0 \%$ \\
\hline $\begin{array}{l}1{ }^{0} \text { grau } \\
\text { completo }\end{array}$ & $11,1 \%$ & $8,8 \%$ & $0,0 \%$ & $0,0 \%$ & $2,8 \%$ & $0,0 \%$ & $0,0 \%$ & $0,0 \%$ & $10,0 \%$ & $0,0 \%$ & $18,2 \%$ & $14,3 \%$ & $0,0 \%$ & $4,5 \%$ & $0,0 \%$ & $0,0 \%$ \\
\hline $\begin{array}{l}2^{0} \text { graul } \\
\text { incompleto }\end{array}$ & $0,0 \%$ & $5,9 \%$ & $0,0 \%$ & $0,0 \%$ & $4,1 \%$ & $6,3 \%$ & $0,0 \%$ & $0,0 \%$ & $5,0 \%$ & $0,0 \%$ & $0,0 \%$ & $0,0 \%$ & $0,0 \%$ & $2,3 \%$ & $11,1 \%$ & $0,0 \%$ \\
\hline $\begin{array}{l}2^{0} \text { graul } \\
\text { completo }\end{array}$ & $11,1 \%$ & $50,0 \%$ & $20,0 \%$ & $15,8 \%$ & $29,0 \%$ & $25,0 \%$ & $16,7 \%$ & $0,0 \%$ & $25,0 \%$ & $0,0 \%$ & $18,2 \%$ & $28,6 \%$ & $0,0 \%$ & $29,5 \%$ & $11,1 \%$ & $14,3 \%$ \\
\hline $\begin{array}{l}\text { Cursando } \\
\text { ensino }\end{array}$ & $0,0 \%$ & $20,6 \%$ & $0,0 \%$ & $15,8 \%$ & $30,3 \%$ & $6,3 \%$ & $25,0 \%$ & $33,3 \%$ & $20,0 \%$ & $0,0 \%$ & $0,0 \%$ & $0,0 \%$ & $28,6 \%$ & $31,8 \%$ & $33,3 \%$ & $0,0 \%$ \\
\hline $\begin{array}{l}\text { Ensino } \\
\text { superior }\end{array}$ & $55,6 \%$ & $14,7 \%$ & $70,0 \%$ & $47,4 \%$ & $26,9 \%$ & $31,3 \%$ & $41,7 \%$ & $33,3 \%$ & $35,0 \%$ & $50,0 \%$ & $45,5 \%$ & $42,9 \%$ & $57,1 \%$ & $15,9 \%$ & $33,3 \%$ & $71,4 \%$ \\
\hline Pós-graduado & $22,2 \%$ & $0,0 \%$ & $10,0 \%$ & $21,1 \%$ & $5,5 \%$ & $25,0 \%$ & $16,7 \%$ & $33,3 \%$ & $5,0 \%$ & $50,0 \%$ & $18,2 \%$ & $14,3 \%$ & $14,3 \%$ & $11,4 \%$ & $0,0 \%$ & $14,3 \%$ \\
\hline Total & $100 \%$ & $100 \%$ & $100 \%$ & $100 \%$ & $100 \%$ & $100 \%$ & $100 \%$ & $100 \%$ & $100 \%$ & $100 \%$ & $100 \%$ & $100 \%$ & $100 \%$ & $100 \%$ & $100 \%$ & $100 \%$ \\
\hline
\end{tabular}


Anex0 4.7. Faixa de renda familiar dos visitantes $x$ estação de amostragem

\begin{tabular}{|c|c|c|c|c|c|c|c|c|c|c|c|c|c|c|c|c|}
\hline \multirow{2}{*}{$\begin{array}{l}\text { Faixa de } \\
\text { renda }\end{array}$} & \multicolumn{16}{|c|}{ Estações de amostragem } \\
\hline & A & B & C1 & C2 & D & E & $F$ & $G$ & $H$ & I & $J$ & $L$ & M & $\mathrm{N}$ & 0 & $\mathrm{P}$ \\
\hline $\begin{array}{l}\text { De R\$250 a } \\
R \$ 500\end{array}$ & $0,0 \%$ & $0,0 \%$ & $0,0 \%$ & $0,0 \%$ & $4,1 \%$ & $0,0 \%$ & $0,0 \%$ & $0,0 \%$ & $5,0 \%$ & $0,0 \%$ & $0,0 \%$ & $0,0 \%$ & $0,0 \%$ & $0,0 \%$ & $11,1 \%$ & $0,0 \%$ \\
\hline $\begin{array}{l}\text { De R\$500 a } \\
R \$ 1000\end{array}$ & $0,0 \%$ & $29,4 \%$ & $0,0 \%$ & $5,3 \%$ & $31,7 \%$ & $0,0 \%$ & $0,0 \%$ & $0,0 \%$ & $5,0 \%$ & $0,0 \%$ & $0,0 \%$ & $0,0 \%$ & $0,0 \%$ & $11,6 \%$ & $11,1 \%$ & $0,0 \%$ \\
\hline $\begin{array}{l}\text { De } R \$ 1000 \text { a } \\
R \$ 2000\end{array}$ & $22,2 \%$ & $26,5 \%$ & $20,0 \%$ & $21,1 \%$ & $34,5 \%$ & $12,5 \%$ & $58,3 \%$ & $0,0 \%$ & $35,0 \%$ & $0,0 \%$ & $18,2 \%$ & $21,4 \%$ & $14,3 \%$ & $18,6 \%$ & $44,4 \%$ & $0,0 \%$ \\
\hline $\begin{array}{l}\text { De R\$2000 a } \\
R \$ 5000\end{array}$ & $66,7 \%$ & $35,3 \%$ & $60,0 \%$ & $31,6 \%$ & $26,9 \%$ & 68,8\% & $41,7 \%$ & $100 \%$ & $30,0 \%$ & $50,0 \%$ & $54,5 \%$ & $57,1 \%$ & $28,6 \%$ & $16,3 \%$ & $33,3 \%$ & $28,6 \%$ \\
\hline $\begin{array}{l}\text { Mais de } \\
R \$ 5000\end{array}$ & $11,1 \%$ & $8,8 \%$ & $20,0 \%$ & $42,1 \%$ & $2,8 \%$ & $18,8 \%$ & $0,0 \%$ & $0,0 \%$ & $25,0 \%$ & $50,0 \%$ & $27,3 \%$ & $21,4 \%$ & $57,1 \%$ & $53,5 \%$ & $0,0 \%$ & $71,4 \%$ \\
\hline Total & $100 \%$ & $100 \%$ & $100 \%$ & $100 \%$ & $100 \%$ & $100 \%$ & $100 \%$ & $100 \%$ & $100 \%$ & $100 \%$ & $100 \%$ & $100 \%$ & $100 \%$ & $100 \%$ & $100 \%$ & $100 \%$ \\
\hline
\end{tabular}


Anexo 5. Quadros-síntese da percepção e grau de exigência ambiental dos visitantes em relação aos impactos provocados pela visitação pública nos empreendimentos de turismo estudados ao longo do rio Formoso

Anex0 5.1. Percepção dos visitantes quanto ao impacto de saltar no rio x estação de amostragem

\begin{tabular}{|c|c|c|c|c|c|c|c|c|c|c|c|c|c|c|c|c|}
\hline \multirow{2}{*}{ Percepção } & \multicolumn{16}{|c|}{ Estações de amostragem } \\
\hline & $A$ & B & $\mathrm{C1}$ & $\mathrm{C} 2$ & D & $E$ & $F$ & G & $H$ & I & $J$ & $L$ & M & N & 0 & $P$ \\
\hline $\begin{array}{l}\text { Não causa } \\
\text { impacto }\end{array}$ & $33,3 \%$ & $50,0 \%$ & $30,0 \%$ & $11,1 \%$ & $66,9 \%$ & $25,0 \%$ & $41,7 \%$ & $0,0 \%$ & $55,0 \%$ & $25,0 \%$ & $18,2 \%$ & $7,1 \%$ & $28,6 \%$ & $36,4 \%$ & $22,2 \%$ & $14,3 \%$ \\
\hline $\begin{array}{c}\text { Causa pouco } \\
\text { impacto }\end{array}$ & $22,2 \%$ & $41,2 \%$ & $40,0 \%$ & $44,4 \%$ & $29,7 \%$ & $62,5 \%$ & $41,7 \%$ & $100 \%$ & $40,0 \%$ & $25,0 \%$ & $63,6 \%$ & $78,6 \%$ & $71,4 \%$ & $40,9 \%$ & $55,6 \%$ & $71,4 \%$ \\
\hline $\begin{array}{c}\text { Causa muito } \\
\text { impacto }\end{array}$ & $44,4 \%$ & $8,8 \%$ & $30,0 \%$ & $44,4 \%$ & $3,4 \%$ & $12,5 \%$ & $16,7 \%$ & $0,0 \%$ & $5,0 \%$ & $50,0 \%$ & $18,2 \%$ & $14,3 \%$ & 0,0\% & $22,7 \%$ & $22,2 \%$ & $14,3 \%$ \\
\hline Total & $100 \%$ & $100 \%$ & $100 \%$ & $100 \%$ & $100 \%$ & $100 \%$ & $100 \%$ & $100 \%$ & $100 \%$ & $100 \%$ & $100 \%$ & $100 \%$ & $100 \%$ & $100 \%$ & $100 \%$ & $100 \%$ \\
\hline $\begin{array}{c}\text { Pontuação de } \\
\text { exigência }\end{array}$ & 111 & 59 & 100 & 133,2 & 37 & 88 & 75 & 100 & 50 & 125 & 100 & 107 & 71 & 86 & 100 & 100 \\
\hline $\begin{array}{l}\text { Nível de exigência } \\
\text { ambiental (\%) }\end{array}$ & 56 & 30 & 50 & 67 & 19 & 44 & 38 & 50 & 25 & 63 & 50 & 54 & 36 & 43 & 50 & 50 \\
\hline
\end{tabular}


Anex0 5.2. Percepção dos visitantes quanto ao impacto de tocar o fundo do rio com os pés x estação de amostragem

\begin{tabular}{|c|c|c|c|c|c|c|c|c|c|c|c|c|c|c|c|c|}
\hline \multirow{2}{*}{ Percepção } & \multicolumn{16}{|c|}{ Estações de amostragem } \\
\hline & A & B & $\mathrm{C1}$ & C2 & D & $E$ & $F$ & G & $\mathrm{H}$ & I & $J$ & $L$ & M & N & 0 & $\mathrm{P}$ \\
\hline $\begin{array}{l}\text { Não causa } \\
\text { impacto }\end{array}$ & $11,1 \%$ & $38,2 \%$ & $10,0 \%$ & $0,0 \%$ & $49,0 \%$ & $18,8 \%$ & $16,7 \%$ & $0,0 \%$ & $55,0 \%$ & $0,0 \%$ & $9,1 \%$ & $7,7 \%$ & $42,9 \%$ & $51,2 \%$ & $33,3 \%$ & $28,6 \%$ \\
\hline $\begin{array}{c}\text { Causa pouco } \\
\text { impacto }\end{array}$ & $33,3 \%$ & $44,1 \%$ & $40,0 \%$ & $55,6 \%$ & $42,1 \%$ & $50,0 \%$ & $50,0 \%$ & $33,3 \%$ & $35,0 \%$ & $0,0 \%$ & $45,5 \%$ & $23,1 \%$ & $14,3 \%$ & $25,6 \%$ & $44,4 \%$ & $28,6 \%$ \\
\hline $\begin{array}{c}\text { Causa muito } \\
\text { impacto }\end{array}$ & $55,6 \%$ & $17,6 \%$ & $50,0 \%$ & $44,4 \%$ & $9,0 \%$ & $31,3 \%$ & $33,3 \%$ & $66,7 \%$ & $10,0 \%$ & $100 \%$ & $45,5 \%$ & $69,2 \%$ & $42,9 \%$ & $23,3 \%$ & $22,2 \%$ & $42,9 \%$ \\
\hline Total & $100 \%$ & $100 \%$ & $100 \%$ & $100 \%$ & $100 \%$ & $100 \%$ & $100 \%$ & $100 \%$ & $100 \%$ & $100 \%$ & $100 \%$ & $100 \%$ & $100 \%$ & $100 \%$ & $100 \%$ & $100 \%$ \\
\hline $\begin{array}{l}\text { Pontuação de } \\
\text { exigência }\end{array}$ & 145 & 79 & 140 & 144 & 60 & 113 & 117 & 167 & 55 & 200 & 137 & 162 & 100 & 72 & 89 & 114 \\
\hline $\begin{array}{l}\text { Nível de exigência } \\
\text { ambiental (\%) }\end{array}$ & 73 & 40 & 70 & 72 & 30 & 57 & 59 & 84 & 28 & 100 & 69 & 81 & 50 & 36 & 45 & 57 \\
\hline
\end{tabular}


Anexo 5.3. Percepção dos visitantes quanto ao impacto de retirar vegetação ou outro material do fundo do rio x estação de amostragem

\begin{tabular}{|c|c|c|c|c|c|c|c|c|c|c|c|c|c|c|c|c|}
\hline \multirow{2}{*}{ Percepção } & \multicolumn{16}{|c|}{ Estações de amostragem } \\
\hline & A & B & C1 & C2 & D & $E$ & $F$ & $G$ & H & I & $J$ & $L$ & M & N & 0 & $P$ \\
\hline Não causa impacto & $0,0 \%$ & $5,9 \%$ & $0,0 \%$ & $5,3 \%$ & $15,9 \%$ & $0,0 \%$ & $0,0 \%$ & $0,0 \%$ & $0,0 \%$ & $0,0 \%$ & $0,0 \%$ & $0,0 \%$ & $0,0 \%$ & $6,8 \%$ & $11,1 \%$ & $0,0 \%$ \\
\hline $\begin{array}{c}\text { Causa pouco } \\
\text { impacto }\end{array}$ & $11,1 \%$ & $38,2 \%$ & $10,0 \%$ & $21,1 \%$ & $53,8 \%$ & $12,5 \%$ & $58,3 \%$ & $0,0 \%$ & $40,0 \%$ & $0,0 \%$ & $9,1 \%$ & $14,3 \%$ & $28,6 \%$ & $13,6 \%$ & $22,2 \%$ & $14,3 \%$ \\
\hline $\begin{array}{c}\text { Causa muito } \\
\text { impacto }\end{array}$ & $88,9 \%$ & $55,9 \%$ & $90,0 \%$ & $73,7 \%$ & $30,3 \%$ & $87,5 \%$ & $41,7 \%$ & $100 \%$ & $60,0 \%$ & $100 \%$ & $90,9 \%$ & $85,7 \%$ & $71,4 \%$ & $79,5 \%$ & $66,7 \%$ & $85,7 \%$ \\
\hline Total & $100 \%$ & $100 \%$ & $100 \%$ & $100 \%$ & $100 \%$ & $100 \%$ & $100 \%$ & $100 \%$ & $100 \%$ & $100 \%$ & $100 \%$ & $100 \%$ & $100 \%$ & $100 \%$ & $100 \%$ & $100 \%$ \\
\hline $\begin{array}{c}\text { Pontuaçãa de } \\
\text { exigência ambiental }\end{array}$ & 189 & 150 & 190 & 169 & 114 & 188 & 142 & 200 & 160 & 200 & 191 & 186 & 171 & 173 & 156 & 186 \\
\hline $\begin{array}{c}\text { Nível de exigência } \\
\text { ambiental (\%) }\end{array}$ & 95 & 75 & 95 & 85 & 57 & 94 & 71 & 100 & 80 & 100 & 96 & 93 & 86 & 87 & 78 & 93 \\
\hline
\end{tabular}


Anexo 5.4. Percepção dos visitantes quanto ao impacto de entrar na água usando protetor solar, bronzeador, hidratante x estação de amostragem

\begin{tabular}{|c|c|c|c|c|c|c|c|c|c|c|c|c|c|c|c|c|}
\hline \multirow{2}{*}{ Percepção } & \multicolumn{16}{|c|}{ Estações de amostragem } \\
\hline & $A$ & B & $\mathrm{C1}$ & C2 & D & E & $F$ & $G$ & $H$ & I & J & $L$ & M & $N$ & 0 & $\mathrm{P}$ \\
\hline $\begin{array}{l}\text { Não causa } \\
\text { impacto }\end{array}$ & $11,1 \%$ & $20,6 \%$ & $0,0 \%$ & $0,0 \%$ & $10,3 \%$ & $0,0 \%$ & $0,0 \%$ & $0,0 \%$ & $10,0 \%$ & $0,0 \%$ & $0,0 \%$ & $0,0 \%$ & $0,0 \%$ & $15,9 \%$ & $11,1 \%$ & $0,0 \%$ \\
\hline $\begin{array}{c}\text { Causa pouco } \\
\text { impacto }\end{array}$ & $11,1 \%$ & $35,3 \%$ & $10,0 \%$ & $31,6 \%$ & $27,6 \%$ & $6,3 \%$ & $33,3 \%$ & $0,0 \%$ & $40,0 \%$ & $0,0 \%$ & $9,1 \%$ & $14,3 \%$ & $42,9 \%$ & $20,5 \%$ & $33,3 \%$ & $57,1 \%$ \\
\hline $\begin{array}{c}\text { Causa muito } \\
\text { impacto }\end{array}$ & $77,8 \%$ & $44,1 \%$ & $90,0 \%$ & $68,4 \%$ & $62,1 \%$ & $93,8 \%$ & $66,7 \%$ & $100 \%$ & $50,0 \%$ & $100 \%$ & $90,9 \%$ & $85,7 \%$ & $57,1 \%$ & $63,6 \%$ & $55,6 \%$ & $42,9 \%$ \\
\hline Total & $100 \%$ & $100 \%$ & $100 \%$ & $100 \%$ & $100 \%$ & $100 \%$ & $100 \%$ & $100 \%$ & $100 \%$ & $100 \%$ & $100 \%$ & $100 \%$ & $100 \%$ & $100 \%$ & $100 \%$ & $100 \%$ \\
\hline $\begin{array}{l}\text { Pontuação de } \\
\text { exigência }\end{array}$ & 167 & 124 & 190 & 168 & 152 & 194 & 167 & 200 & 140 & 200 & 191 & 186 & 157 & 148 & 145 & 143 \\
\hline $\begin{array}{l}\text { Nível de exigência } \\
\text { ambiental (\%) }\end{array}$ & 84 & 62 & 95 & 84 & 76 & 97 & 84 & 100 & 70 & 100 & 96 & 93 & 79 & 74 & 73 & 72 \\
\hline
\end{tabular}


Anexo 5.5. Percepção dos visitantes quanto ao impacto de subir ou deslizar sobre as tufass calcárias x estação de amostrag̨em

\begin{tabular}{|c|c|c|c|c|c|c|c|c|c|c|c|c|c|c|c|c|}
\hline \multirow{2}{*}{ Percepção } & \multicolumn{16}{|c|}{ Estações de amostragem } \\
\hline & $A$ & B & C1 & C2 & D & $E$ & $F$ & $G$ & H & I & $\mathrm{J}$ & L & M & N & 0 & $P$ \\
\hline Não causa impacto & $0,0 \%$ & $32,4 \%$ & $0,0 \%$ & $10,5 \%$ & $55,2 \%$ & $12,5 \%$ & $41,7 \%$ & $0,0 \%$ & $50,0 \%$ & $0,0 \%$ & $18,2 \%$ & $0,0 \%$ & $28,6 \%$ & $25,0 \%$ & $33,3 \%$ & $16,7 \%$ \\
\hline $\begin{array}{l}\text { Causa pouco } \\
\text { impacto }\end{array}$ & $33,3 \%$ & $29,4 \%$ & $30,0 \%$ & $52,6 \%$ & $28,3 \%$ & $43,8 \%$ & $33,3 \%$ & $0,0 \%$ & $30,0 \%$ & $0,0 \%$ & $18,2 \%$ & $28,6 \%$ & $28,6 \%$ & $47,7 \%$ & $33,3 \%$ & $33,3 \%$ \\
\hline Causa muito impacto & $66,7 \%$ & $38,2 \%$ & $70,0 \%$ & $36,8 \%$ & $16,6 \%$ & $43,8 \%$ & $25,0 \%$ & $100 \%$ & $20,0 \%$ & $100 \%$ & $63,6 \%$ & $71,4 \%$ & $42,9 \%$ & $27,3 \%$ & $33,3 \%$ & $50,0 \%$ \\
\hline Total & $100 \%$ & $100 \%$ & $100 \%$ & $100 \%$ & $100 \%$ & $100 \%$ & $100 \%$ & $100 \%$ & $100 \%$ & $100 \%$ & $100 \%$ & $100 \%$ & $100 \%$ & $100 \%$ & $100 \%$ & $100 \%$ \\
\hline \begin{tabular}{|c|} 
Pontuação de \\
exigência ambiental
\end{tabular} & 167 & 106 & 170 & 126 & 62 & 131 & 83 & 200 & 70 & 200 & 145 & 171 & 114 & 102 & 100 & 133 \\
\hline $\begin{array}{c}\text { Nível de exigência } \\
\text { ambiental (\%) }\end{array}$ & 84 & 53 & 85 & 63 & 31 & 66 & 42 & 100 & 35 & 100 & 73 & 86 & 57 & 51 & 50 & 67 \\
\hline
\end{tabular}


Anexo 5.6. Percepção dos visitantes quanto ao impacto de deixar lixo fora da lixeira x estação de amostrag̨em

\begin{tabular}{|c|c|c|c|c|c|c|c|c|c|c|c|c|c|c|c|c|}
\hline \multirow{2}{*}{ Percepção } & \multicolumn{16}{|c|}{ Estações de amostragem } \\
\hline & A & B & $\mathrm{Cl}$ & C2 & D & $E$ & $F$ & G & H & I & J & L & M & $\mathrm{N}$ & 0 & $p$ \\
\hline Não causa impacto & $0,0 \%$ & $0,0 \%$ & $0,0 \%$ & $0,0 \%$ & $3,4 \%$ & $0,0 \%$ & $0,0 \%$ & $0,0 \%$ & $0,0 \%$ & $0,0 \%$ & $0,0 \%$ & $0,0 \%$ & $0,0 \%$ & $0,0 \%$ & $0,0 \%$ & $0,0 \%$ \\
\hline $\begin{array}{c}\text { Causa pouco } \\
\text { impacto }\end{array}$ & $0,0 \%$ & $2,9 \%$ & $0,0 \%$ & $15,8 \%$ & $15,9 \%$ & $12,5 \%$ & $16,7 \%$ & $0,0 \%$ & $0,0 \%$ & $0,0 \%$ & $0,0 \%$ & $14,3 \%$ & $0,0 \%$ & $7,0 \%$ & $0,0 \%$ & $0,0 \%$ \\
\hline $\begin{array}{l}\text { Causa muito } \\
\text { impacto }\end{array}$ & $100 \%$ & $97,1 \%$ & $100 \%$ & $84,2 \%$ & $80,7 \%$ & $87,5 \%$ & $83,3 \%$ & $100 \%$ & $100 \%$ & $100 \%$ & $100 \%$ & $85,7 \%$ & $100 \%$ & $93,0 \%$ & $100 \%$ & $100 \%$ \\
\hline Total & $100 \%$ & $100 \%$ & $100 \%$ & $100 \%$ & $100 \%$ & $100 \%$ & $100 \%$ & $100 \%$ & $100 \%$ & $100 \%$ & $100 \%$ & $100 \%$ & $100 \%$ & $100 \%$ & $100 \%$ & $100 \%$ \\
\hline $\begin{array}{l}\text { Pontuação de } \\
\text { exigência }\end{array}$ & 200 & 197 & 200 & 184 & 177 & 188 & 183 & 200 & 200 & 200 & 200 & 186 & 200 & 193 & 200 & 200 \\
\hline $\begin{array}{c}\text { Nível de exigência } \\
\text { ambiental (\%) }\end{array}$ & 100 & 99 & 100 & 92 & 89 & 94 & 92 & 100 & 100 & 100 & 100 & 93 & 100 & 97 & 100 & 100 \\
\hline
\end{tabular}


Anexo 5.7. Percepção dos visitantes quanto ao impacto de pisar sobre pequenas plantas na margem x estação de amostragem

\begin{tabular}{|c|c|c|c|c|c|c|c|c|c|c|c|c|c|c|c|c|}
\hline \multirow{2}{*}{ Percepção } & \multicolumn{16}{|c|}{ Estações de amostragem } \\
\hline & A & B & C1 & C2 & $D$ & $E$ & $F$ & $G$ & $H$ & I & $\mathrm{J}$ & $L$ & M & $\mathrm{N}$ & 0 & $P$ \\
\hline $\begin{array}{l}\text { Não causa } \\
\text { impacto }\end{array}$ & $0,0 \%$ & $38,2 \%$ & $0,0 \%$ & $0,0 \%$ & $33,6 \%$ & $0,0 \%$ & $8,3 \%$ & $0,0 \%$ & $10,0 \%$ & $0,0 \%$ & $27,3 \%$ & $0,0 \%$ & $0,0 \%$ & $15,9 \%$ & $11,1 \%$ & $14,3 \%$ \\
\hline $\begin{array}{l}\text { Causa pouco } \\
\text { impacto }\end{array}$ & $55,6 \%$ & $29,4 \%$ & $20,0 \%$ & $47,4 \%$ & $46,9 \%$ & $81,3 \%$ & $50,0 \%$ & $0,0 \%$ & $55,0 \%$ & $50,0 \%$ & $0,0 \%$ & $21,4 \%$ & $57,1 \%$ & $43,2 \%$ & $44,4 \%$ & $28,6 \%$ \\
\hline $\begin{array}{l}\text { Causa muito } \\
\text { impacto }\end{array}$ & $44,4 \%$ & $32,4 \%$ & $80,0 \%$ & $52,6 \%$ & $19,6 \%$ & $18,8 \%$ & $41,7 \%$ & $100 \%$ & $35,0 \%$ & $50,0 \%$ & $72,7 \%$ & $78,6 \%$ & $42,9 \%$ & $40,9 \%$ & $44,4 \%$ & $57,1 \%$ \\
\hline Total & $100 \%$ & $100 \%$ & $100 \%$ & $100 \%$ & $100 \%$ & $100 \%$ & $100 \%$ & $100 \%$ & $100 \%$ & $100 \%$ & $100 \%$ & $100 \%$ & $100 \%$ & $100 \%$ & $100 \%$ & $100 \%$ \\
\hline $\begin{array}{l}\text { Pontuação de } \\
\text { exigência }\end{array}$ & 144 & 94 & 180 & 153 & 86 & 119 & 133 & 200 & 125 & 150 & 145 & 179 & 143 & 125 & 133 & 143 \\
\hline $\begin{array}{l}\text { Nível de } \\
\text { exigência }\end{array}$ & 72 & 47 & 90 & 77 & 43 & 60 & 67 & 100 & 63 & 75 & 73 & 90 & 72 & 63 & 67 & 72 \\
\hline
\end{tabular}


Anexo 5.8. Percepção dos visitantes quanto ao impacto de abrir trilhas na margem do rio x estação de amostragem

\begin{tabular}{|c|c|c|c|c|c|c|c|c|c|c|c|c|c|c|c|c|}
\hline \multirow{2}{*}{ Percepção } & \multicolumn{16}{|c|}{ Estações de amostragem } \\
\hline & A & B & $C 1$ & C2 & D & E & $\mathrm{F}$ & G & H & 1 & J & L & M & $\mathrm{N}$ & 0 & $\mathrm{P}$ \\
\hline Não causa impacto & $22,2 \%$ & $0,0 \%$ & $0,0 \%$ & $11,1 \%$ & $9,7 \%$ & $0,0 \%$ & $0,0 \%$ & $0,0 \%$ & $5,0 \%$ & $0,0 \%$ & $0,0 \%$ & $0,0 \%$ & $0,0 \%$ & $0,0 \%$ & $0,0 \%$ & $14,3 \%$ \\
\hline $\begin{array}{l}\text { Causa pouco } \\
\text { impacto }\end{array}$ & $0,0 \%$ & $5,9 \%$ & $0,0 \%$ & $27,8 \%$ & $40,0 \%$ & $18,8 \%$ & $33,3 \%$ & $0,0 \%$ & $25,0 \%$ & $25,0 \%$ & $9,1 \%$ & $7,1 \%$ & $14,3 \%$ & $27,3 \%$ & $22,2 \%$ & $0,0 \%$ \\
\hline $\begin{array}{l}\text { Causa muito } \\
\text { impacto }\end{array}$ & $77,8 \%$ & $94,1 \%$ & $100 \%$ & $61,1 \%$ & $50,3 \%$ & $81,3 \%$ & $66,7 \%$ & $100 \%$ & $70,0 \%$ & $75,0 \%$ & $90,9 \%$ & $92,9 \%$ & $85,7 \%$ & $72,7 \%$ & $77,8 \%$ & $85,7 \%$ \\
\hline Total & $100 \%$ & $100 \%$ & $100 \%$ & $100 \%$ & $100 \%$ & $100 \%$ & $100 \%$ & $100 \%$ & $100 \%$ & $100 \%$ & $100 \%$ & $100 \%$ & $100 \%$ & $100 \%$ & $100 \%$ & $100 \%$ \\
\hline $\begin{array}{l}\text { Pontuação de } \\
\text { exigência } \\
\text { ambiental }\end{array}$ & 156 & 194 & 200 & 150 & 141 & 181 & 167 & 200 & 165 & 175 & 191 & 193 & 186 & 173 & 178 & 171 \\
\hline $\begin{array}{l}\text { Nível de exigência } \\
\text { ambiental (\%) }\end{array}$ & 78 & 97 & 100 & 75 & 71 & 91 & 84 & 100 & 83 & 88 & 96 & 97 & 93 & 87 & 89 & 86 \\
\hline
\end{tabular}


Anexo 5.9. Percepção dos visitantes quanto ao impacto do som alto x estação de amostragem

\begin{tabular}{|c|c|c|c|c|c|c|c|c|c|c|c|c|c|c|c|c|}
\hline \multirow{2}{*}{ Percepção } & \multicolumn{16}{|c|}{ Estações de amostragem } \\
\hline & $A$ & B & $\mathrm{C1}$ & C2 & D & $E$ & $F$ & $G$ & $H$ & I & J & L & M & $\mathrm{N}$ & 0 & $P$ \\
\hline Não causa impacto & $33,3 \%$ & $14,7 \%$ & $0,0 \%$ & $10,5 \%$ & $66,9 \%$ & $0,0 \%$ & $25,0 \%$ & $0,0 \%$ & $55,0 \%$ & $0,0 \%$ & $0,0 \%$ & $0,0 \%$ & $28,6 \%$ & $36,4 \%$ & $11,1 \%$ & $0,0 \%$ \\
\hline $\begin{array}{l}\text { Causa pouco } \\
\text { impacto }\end{array}$ & $0,0 \%$ & $35,3 \%$ & $10,0 \%$ & $15,8 \%$ & $13,8 \%$ & $25,0 \%$ & $25,0 \%$ & $0,0 \%$ & $25,0 \%$ & $0,0 \%$ & $0,0 \%$ & $0,0 \%$ & $28,6 \%$ & $22,7 \%$ & $33,3 \%$ & $0,0 \%$ \\
\hline Causa muito impacto & $66,7 \%$ & $50,0 \%$ & $90,0 \%$ & $73,7 \%$ & $19,3 \%$ & $75,0 \%$ & $50,0 \%$ & $100 \%$ & $20,0 \%$ & $100 \%$ & $100 \%$ & $100 \%$ & $42,9 \%$ & $40,9 \%$ & $55,6 \%$ & $100 \%$ \\
\hline |Total & $100 \%$ & $100 \%$ & $100 \%$ & $100 \%$ & $100 \%$ & $100 \%$ & $100 \%$ & $100 \%$ & $100 \%$ & $100 \%$ & $100 \%$ & $100 \%$ & $100 \%$ & $100 \%$ & $100 \%$ & $100 \%$ \\
\hline \begin{tabular}{|l|} 
Pontuação de \\
exigência ambiental
\end{tabular} & 133 & 135 & 190 & 163 & 52 & 175 & 125 & 200 & 65 & 200 & 200 & 200 & 114 & 105 & 145 & 200 \\
\hline $\begin{array}{l}\text { Nível de exigência } \\
\text { ambiental (\%) }\end{array}$ & 67 & 68 & 95 & 82 & 26 & 88 & 63 & 100 & 33 & 100 & 100 & 100 & 57 & 53 & 73 & 100 \\
\hline
\end{tabular}


Anexo 5.10. Pontuação total do grau de exigência ambiental (\%) em relação à exigência ambiental máxima para cada atividade impactante por empreendimento estudado

\begin{tabular}{|c|c|c|c|c|c|c|c|c|c|c|c|c|c|c|c|c|}
\hline Percepção & \multicolumn{10}{|c|}{ Estações de amostragem } \\
\hline & A & B & C1 & C2 & D & E & F & G & H & I & J & L & M & N & O & P \\
\hline 1. Saltar no rio & 56 & 30 & 50 & 67 & 19 & 44 & 38 & 50 & 25 & 63 & 50 & 54 & 36 & 43 & 50 & 50 \\
\hline 2. Tocar o fundo com os pés & 73 & 40 & 70 & 72 & 30 & 57 & 59 & 84 & 28 & 100 & 69 & 81 & 50 & 36 & 45 & 57 \\
\hline 3. Retirar material do fundo & 95 & 75 & 95 & 85 & 57 & 94 & 71 & 100 & 80 & 100 & 96 & 93 & 86 & 87 & 78 & 93 \\
\hline 4. Entrar na água cl protetor, & 84 & 62 & 95 & 84 & 76 & 97 & 84 & 100 & 70 & 100 & 96 & 93 & 79 & 74 & 73 & 72 \\
\hline 5. Subir ou deslizar sobre as tufas & 84 & 53 & 85 & 63 & 31 & 66 & 42 & 100 & 35 & 100 & 73 & 86 & 57 & 51 & 50 & 67 \\
\hline 6. Deixar lixo fora da lixeira & 100 & 99 & 100 & 92 & 89 & 94 & 92 & 100 & 100 & 100 & 100 & 93 & 100 & 97 & 100 & 100 \\
\hline 7. Pisar sobre pequenas plantas & 72 & 47 & 90 & 77 & 43 & 60 & 67 & 100 & 63 & 75 & 73 & 90 & 72 & 63 & 67 & 72 \\
\hline 8. Abrir trilhas na margem & 78 & 97 & 100 & 75 & 71 & 91 & 84 & 100 & 83 & 88 & 96 & 97 & 93 & 87 & 89 & 86 \\
\hline 9. Som alto & 67 & 68 & 95 & 82 & 26 & 88 & 63 & 100 & 33 & 100 & 100 & 100 & 57 & 53 & 73 & 100 \\
\hline Pontuação total* & 1412 & 1138 & 1560 & 1324 & 881 & 1377 & 1192 & 1667 & 1030 & 1650 & 1500 & 1570 & 1256 & 1177 & 1246 & 1390 \\
\hline \% da pontuação máxima total & 78,4 & 63,2 & 86,7 & 73,6 & 48,9 & 76,5 & 66,2 & 92,6 & 57,2 & 91,7 & 83,3 & 87,2 & 69,8 & 65,4 & 69,2 & 77,2 \\
\hline Categorias de exigência & A & M & A & M & MB & A & M & MA & M & MA & A & A & M & M & M & M \\
\hline
\end{tabular}

*Pontuação máxima total: 1800 (grau de exigência ambiental máxima possível de ser atingida)

*CCategorias de exigência ambiental: $\leq 35 \%$ - Muito baixa (MB); $36-50 \%$ - Baixa (B); $51-75 \%$ - Média (M); $76-90 \%$ - Alta (A); $\geq 90 \%$ - Muito alta (MA) 
Anexo 6. Indicadores das condições da água medidos nas estações de amostragem, considerando pontos em áreas controle (c) e áreas impactadas (i)

\begin{tabular}{|c|c|c|c|c|c|c|c|c|c|c|c|c|c|}
\hline 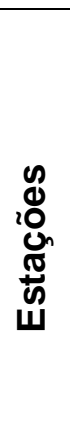 & $\begin{array}{l}\text { : } \\
\stackrel{0}{t} \\
\text { Oे }\end{array}$ & 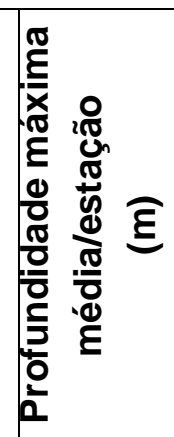 & 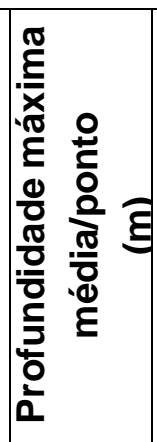 & 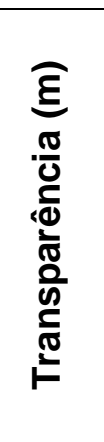 & 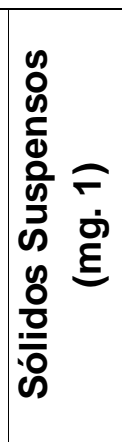 & 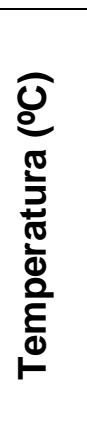 & 종 & 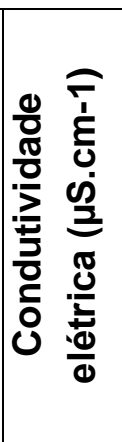 & $\begin{array}{l}\widehat{T} \\
\dot{3} \\
\dot{0} \\
\dot{0} \\
0 \\
0\end{array}$ & 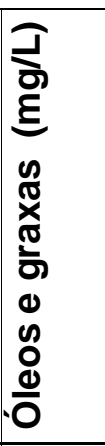 & 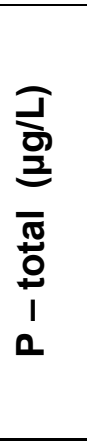 & 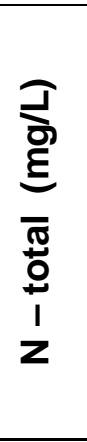 & 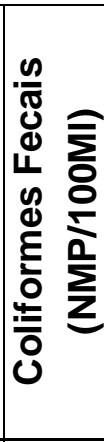 \\
\hline \multirow[t]{2}{*}{$A$} & $A C$ & \multirow[t]{2}{*}{1,2} & 1,0 & 6,8 & 1,3 & 23,7 & 7,1 & 233 & 4,8 & 4 & 11,93 & 0,28 & 345 \\
\hline & $\mathrm{Ai}$ & & 0,8 & 7,8 & 0,9 & 23,7 & 7,2 & 233 & 4,4 & 3 & 11,2 & 0,51 & 158 \\
\hline \multirow[t]{2}{*}{$\bar{B}$} & $\overline{B C}$ & \multirow[t]{2}{*}{1,4} & $\overline{1,3}$ & 8,0 & $\overline{0,9}$ & 23,2 & 7,3 & 205 & 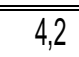 & 4 & 12,51 & 0,28 & 158 \\
\hline & $\mathrm{Bi}$ & & 1,4 & 8,3 & 0,7 & 23,2 & 7,3 & 209 & 4,2 & 4 & 10,4 & 0,28 & 275 \\
\hline \multirow[t]{2}{*}{$\bar{c}$} & $\overline{c c}$ & \multirow[t]{2}{*}{2,5} & $\overline{2,5}$ & $\overline{\overline{12,8}}$ & $\overline{0,3}$ & 25,7 & 7,8 & 208 & 7,0 & $\overline{3}$ & 8,6 & 0,28 & 41 \\
\hline & $\mathrm{Ci}$ & & 2,3 & 11,6 & 0,4 & 25,6 & 7,9 & 202 & 6,9 & 4 & 8,8 & 0,42 & 20 \\
\hline \multirow[t]{2}{*}{$D$} & $\overline{D C}$ & \multirow[t]{2}{*}{2,2} & $\overline{1,8}$ & 11,6 & 0,4 & 25,2 & 7,9 & 201 & 6,7 & 2 & 9,4 & 0,37 & 52 \\
\hline & $\overline{D i}$ & & 1,4 & 3,9 & 2,7 & 25,6 & 7,9 & 200 & 7,0 & 2 & 14,0 & 0,28 & 160 \\
\hline \multirow[t]{2}{*}{$\mathrm{E}$} & $\overline{E C}$ & \multirow[t]{2}{*}{2,5} & 1,8 & 4,5 & 2,4 & 25,6 & 7,9 & 200 & 7,0 & 2 & 10,8 & 0,33 & 41 \\
\hline & $\overline{E i}$ & & 1,9 & 6,8 & 1,3 & 25,7 & 7,6 & 201 & 6,5 & $<2$ & 5,7 & 0,47 & 86 \\
\hline \multirow[t]{2}{*}{$F$} & $\overline{F C}$ & \multirow[t]{2}{*}{3,6} & 1,8 & 5,2 & $1, \overline{1,9}$ & 25,8 & $7,7,9$ & 218 & 6,6 & 3 & 9,23 & 0,28 & 855,0 \\
\hline & $\overline{\mathrm{Fi}}$ & & 1,3 & 3,0 & 3,0 & 26,0 & 8,0 & 215 & 7,0 & $<2$ & 14,63 & 0,09 & 350,0 \\
\hline \multirow[t]{2}{*}{$\bar{G}$} & $\overline{\mathrm{GC}}$ & \multirow[t]{2}{*}{1,9} & $\overline{1,5}$ & $\overline{5,4}$ & 1,9 & 25,9 & $\overline{77,8}$ & $\overline{189,2}$ & $\overline{6,3}$ & $\overline{<<2}$ & 27,77 & 0,33 & $<<10$ \\
\hline & $\overline{\mathrm{Gi}}$ & & 1,4 & 5,2 & 2,1 & 25,9 & 7,8 & 187,6 & 6,3 & $<2$ & 21,78 & 0,05 & 86 \\
\hline \multirow[t]{2}{*}{$\overline{\mathrm{H}}$} & $\overline{\mathrm{HC}}$ & \multirow{2}{*}{2,0} & 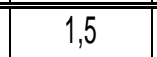 & $\overline{5,3}$ & \begin{tabular}{|c|}
1,8 \\
\end{tabular} & 25,4 & $\overline{8,0}$ & 216 & $\overline{77,0}$ & 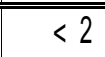 & $\begin{array}{l}6,72 \\
\end{array}$ & 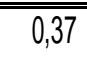 & 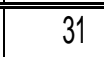 \\
\hline & $\mathrm{Hi}$ & & 1,3 & 2,1 & 3,5 & 25,4 & 8,0 & 219 & 6,4 & 4 & 10,39 & 0,51 & 63 \\
\hline \multirow[t]{2}{*}{1} & $\overline{\text { IC }}$ & \multirow[t]{2}{*}{$\overline{3,5}$} & 2,0 & $\overline{~ 5,1}$ & $\overline{1,7}$ & 25,7 & $7,7,4$ & 2222 & $\overline{6,3}$ & $\frac{1<2}{<<2}$ & 25,84 & 0,37 & $\overline{411}$ \\
\hline & Ii & & 1,5 & 4,8 & 1,9 & 25,5 & 8,0 & 222 & 6,9 & $<2$ & 10,15 & 0,23 & 146 \\
\hline
\end{tabular}


Anexo 6. Continuação...

\begin{tabular}{|c|c|c|c|c|c|c|c|c|c|c|c|c|c|}
\hline 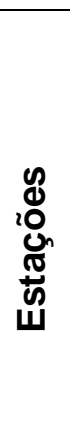 & $\begin{array}{l}\stackrel{0}{0} \\
\stackrel{0}{0} \\
0\end{array}$ & 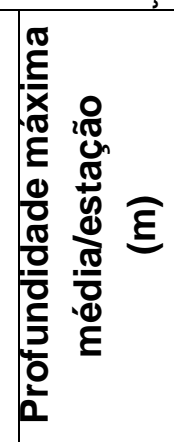 & 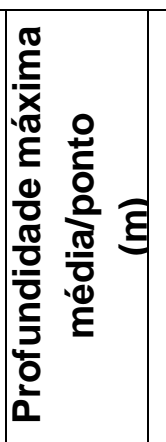 & 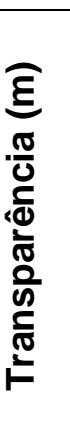 & 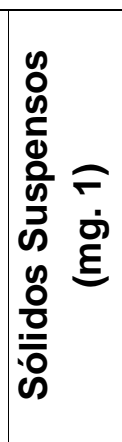 & 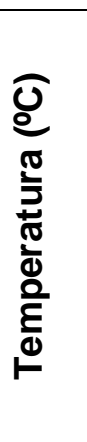 & 종 & 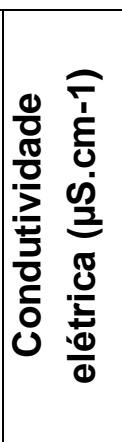 & 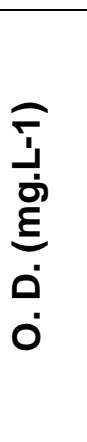 & 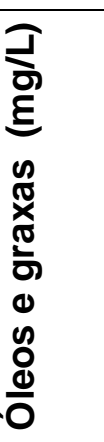 & 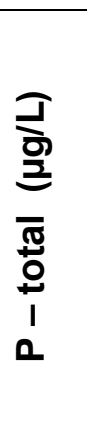 & 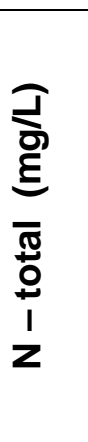 & 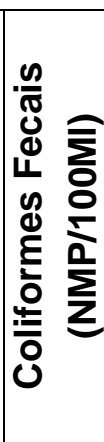 \\
\hline \multirow[t]{2}{*}{$J$} & $\overline{J c}$ & \multirow[t]{2}{*}{4,5} & $\overline{\overline{4,1}}$ & $\overline{25,0}$ & $\overline{11,7}$ & 26,4 & $\overline{8,1}$ & 202 & $6, \overline{6,5}$ & $\overline{44}$ & $7,7,30$ & $0,0,28$ & 98 \\
\hline & Ji & & 4,0 & 5,0 & 1,7 & 26,4 & 8,0 & 203 & 6,5 & 3 & 12,32 & 0,33 & 31 \\
\hline \multirow[t]{2}{*}{ L } & LC & \multirow[t]{2}{*}{4,0} & 2,4 & 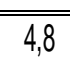 & $\overline{11,8}$ & 26,2 & 8,0 & 204 & $6,6,84$ & $\overline{c<2}$ & $\overline{6,72}$ & $\overline{c 0,05}$ & 30 \\
\hline & Li & & 1,7 & 3,0 & 2,7 & 25,8 & 8,0 & 197,5 & 6,3 & $<2$ & 9,34 & 0,33 & 20 \\
\hline \multirow[t]{2}{*}{ M } & $\overline{\overline{M c}}$ & \multirow[t]{2}{*}{4,0} & 2,6 & 4,8 & 1,7 & 26,3 & $\overline{8,0}$ & 191,2 & 7,3 & 3 & 17,15 & 0,42 & 30 \\
\hline & $\overline{\mathrm{Mi}}$ & & 1,7 & 3,4 & 2,8 & 26,3 & 8,2 & 193,8 & 7,0 & $<2$ & 31,63 & 0,33 & 41 \\
\hline \multirow[t]{2}{*}{$N$} & $\overline{\mathrm{NC}}$ & \multirow[t]{2}{*}{4,0} & 2,6 & 3,3 & 2,8 & 26,0 & 8,0 & 206 & 6,2 & $<2$ & 21,01 & 0,28 & 10 \\
\hline & $\overline{\mathrm{Ni}}$ & & 2,4 & 2,9 & 2,7 & 26,3 & 8,0 & 202 & 6,8 & $<2$ & 27,96 & 0,28 & 30 \\
\hline \multirow[t]{2}{*}{0} & $0 c$ & \multirow[t]{2}{*}{3,5} & $\overline{1,7}$ & 2,9 & 2,6 & 25,9 & 8,0 & 211 & 7,2 & $<2$ & 77,59 & 0,37 & 20 \\
\hline & $0 \mathrm{i}$ & & 1,2 & 1,8 & 3,7 & 25,7 & 8,0 & 211 & 6,98 & $<2$ & 78,94 & 0,33 & 31 \\
\hline \multirow[t]{2}{*}{$P$} & $\overline{\mathrm{PC}}$ & \multirow[t]{2}{*}{3,5} & $\overline{1,7}$ & $\overline{2,5}$ & $\overline{3,4}$ & $\overline{26,7}$ & $\overline{8,2}$ & $\overline{1777,7}$ & 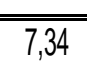 & $\overline{4}$ & 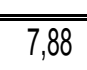 & $\overline{0,37}$ & $\overline{20}$ \\
\hline & $P C$ & & 1,6 & 2,5 & 3,4 & 26,1 & 8,0 & 179,1 & 7,6 & $<2$ & 31,24 & 0,42 & 52 \\
\hline
\end{tabular}


Anexo 7. Indicadores das condições do sedimento medidos nas estações de amostragem, considerando pontos em áreas controle (c) e áreas impactadas (i)

\begin{tabular}{|c|c|c|c|c|c|c|c|c|c|}
\hline Estaçôes & Pontos & $\begin{array}{l}\text { Profundidade } \\
\text { máxima } \\
\text { médialestação } \\
\text { (m) }\end{array}$ & $\begin{array}{l}\text { Profundidade } \\
\text { máxima } \\
\text { média/ponto } \\
\text { (m) }\end{array}$ & $\begin{array}{l}\text { Folhedo } \\
(\%)\end{array}$ & $\begin{array}{c}\text { Mat. orgânica } \\
\text { fina } \\
(\%)\end{array}$ & $\begin{array}{l}\text { P total } \\
\text { (mg/Kg) }\end{array}$ & $\begin{array}{l}\text { N total } \\
(\%)\end{array}$ & $\begin{array}{c}\text { Texturas Gran. } \\
\text { Fina } \\
(\%)\end{array}$ & $\begin{array}{c}\text { Texturas Gran } \\
\text { Grossa } \\
(\%)\end{array}$ \\
\hline \multirow{2}{*}{ A } & Ac - Barra do & \multirow{2}{*}{1,2} & 0,9 & 30 & 3,60 & 0,534 & 0,98 & 53,00 & 47,0 \\
\hline & \begin{tabular}{|l|} 
Ai - Barra do \\
\end{tabular} & & 0,7 & 10 & 0,80 & 0,300 & 0,20 & 12,5 & 87,5 \\
\hline \multirow[t]{2}{*}{$\bar{B}$} & Bc - Praia da & \multirow{2}{*}{1,4} & $\overline{11,6}$ & 50 & 11,0 & (0,0990 & 2,94 & 446,30 & 53,7 \\
\hline & Bi- Praia da & & 1,3 & 20 & 19,80 & 0,1200 & 5,55 & 35,70 & 64,3 \\
\hline \multirow[t]{2}{*}{ c } & Cc-Bonito & \multirow[t]{2}{*}{2,5} & 2,5 & 70 & 20,20 & 0,0900 & 0,19 & 48,70 & $\overline{51,3}$ \\
\hline & \begin{tabular}{|l|} 
Ci-Bonito \\
\end{tabular} & & 2,3 & 30 & 5,80 & 0,0740 & 1,79 & 79,50 & 20,5 \\
\hline \multirow[t]{2}{*}{ D } & DC- & \multirow[t]{2}{*}{2,2} & $\overline{1,7}$ & $\overline{80}$ & $\overline{\overline{10,40}}$ & 0,0480 & 2,18 & $\overline{54,40}$ & $\overline{45,6}$ \\
\hline & Di- & & 1,3 & 10 & 1,80 & 0,0380 & 0,57 & 5,80 & 94,2 \\
\hline \multirow[t]{2}{*}{$\mathrm{E}$} & Ec-Hotel & \multirow[t]{2}{*}{2,5} & $\overline{11,7}$ & 50 & 2,60 & 0,0480 & 0,73 & 14,90 & 85,1 \\
\hline & \begin{tabular}{|l|} 
Ei-Hotel \\
\end{tabular} & & 1,5 & 40 & 2,40 & 0,0480 & 0,69 & 24,70 & 75,3 \\
\hline \multirow[t]{2}{*}{$\mathrm{F}$} & FC. & \multirow[t]{2}{*}{3,6} & 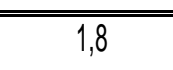 & 90 & 7,20 & 0,0560 & 2,15 & 47,80 & $\overline{\overline{52,2}}$ \\
\hline & \begin{tabular}{|l|} 
Fi - Balneário \\
\end{tabular} & & 1,1 & 10 & 1,00 & 0,0430 & 0,25 & 3,90 & 96,1 \\
\hline \multirow[t]{2}{*}{ G } & Gc - birapê & \multirow[t]{2}{*}{1,9} & 1,20 & 30 & 3,20 & 0,0450 & 0,73 & 23,10 & 76,9 \\
\hline & Gi - lbirapê & & 0,90 & 10 & 1,20 & 0,0420 & 0,41 & 13,90 & 86,1 \\
\hline \multirow[t]{2}{*}{ H } & Hc- & \multirow[t]{2}{*}{2,0} & 1,10 & 40 & 2,20 & 0,0540 & 0,77 & 12,50 & 87,5 \\
\hline & Hi- & & 1,0 & 10 & 1,40 & 0,0520 & 0,29 & 3,60 & 96,4 \\
\hline \multirow[t]{2}{*}{1} & Ic - Hotel Sta & \multirow[t]{2}{*}{3,5} & 1,9 & 90 & $\overline{12,40}$ & 0,0800 & 2,95 & 68,20 & 31,8 \\
\hline & Ii - Hotel St" & & 1,8 & 40 & 7,00 & 0,0560 & 1,56 & 73,20 & 26,8 \\
\hline
\end{tabular}


Anexo 7. Continuação...

\begin{tabular}{|c|c|c|c|c|c|c|c|c|c|}
\hline Estações & Pontos & $\begin{array}{l}\text { Profundidade } \\
\text { máxima } \\
\text { média/estação } \\
\text { (m) }\end{array}$ & $\begin{array}{l}\text { Profundidade } \\
\text { máxima } \\
\text { média/ponto } \\
\text { (m) }\end{array}$ & $\begin{array}{c}\text { Folhedo } \\
(\%)\end{array}$ & $\begin{array}{c}\text { Mat. orgânica } \\
\text { fina } \\
(\%)\end{array}$ & $\begin{array}{l}\text { P total } \\
(\mathrm{mg} / \mathrm{Kg})\end{array}$ & $\begin{array}{c}\text { N total } \\
(\%)\end{array}$ & $\begin{array}{c}\text { Texturas Gran. } \\
\text { Fina } \\
(\%)\end{array}$ & $\begin{array}{c}\text { Texturas Gran. } \\
\text { Grossa } \\
(\%)\end{array}$ \\
\hline \multirow[t]{2}{*}{$\bar{~} \bar{J}$} & Jc - Faz. Iha & \multirow[t]{2}{*}{4,5} & $4 \overline{4,5}$ & $\overline{50}$ & 6,00 & $0,0,0540$ & 1,56 & 42,80 & $\overline{57,2}$ \\
\hline & Ji - Faz. Iha & & 4,1 & 50 & 7,40 & 0,0690 & 1,81 & 77,10 & 22,9 \\
\hline \multirow[t]{2}{*}{$\overline{\mathrm{LL}}$} & Lc - Estância & \multirow[t]{2}{*}{4,0} & 2,0 & 100 & 2,20 & 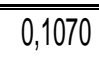 & 4,68 & 68,10 & 31,9 \\
\hline & Li - Estância & & 1,4 & 10 & 2,40 & 0,0680 & 0,43 & 56,30 & 43,7 \\
\hline \multirow[t]{2}{*}{ M } & Mc - Hotel & \multirow[t]{2}{*}{4,0} & 2,2 & 20 & 3,20 & 0,0680 & 1,22 & 43,60 & 91,0 \\
\hline & Mi - Hotel & & 1,6 & 10 & 2,20 & 0,0600 & 0,60 & 9,00 & 56,4 \\
\hline \multirow[t]{2}{*}{$\mathrm{N}$} & Nc - llha do & \multirow[t]{2}{*}{4,0} & 2,80 & 70 & 4,00 & 0,1430 & 0,28 & 12,90 & 87,1 \\
\hline & $\mathrm{Ni}$ - Iha do & & 2,60 & 70 & 4,80 & 0,1550 & 1,13 & 51,10 & 48,9 \\
\hline \multirow[t]{2}{*}{0} & $0 c-$ & \multirow[t]{2}{*}{ 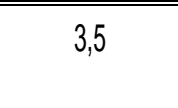 } & $1 \overline{1,6}$ & 70 & $\overline{5,60}$ & 0,0660 & 1,67 & 35,20 & 64,8 \\
\hline & Oi-Camping & & 1,1 & 10 & 1,80 & 0,0520 & 0,25 & 5,10 & 94,9 \\
\hline \multirow[t]{2}{*}{$P$} & Pc-Hotel & \multirow{2}{*}{3,5} & $\overline{~ 1,8}$ & 90 & 8,60 & 0,1550 & 2,06 & 32,10 & 67,9 \\
\hline & Pi-Hotel & & 1,8 & 30 & 4,80 & 0,0720 & 1,22 & 75,90 & 24,1 \\
\hline
\end{tabular}


Anexo 8. Métricas descritoras da estrutura de comunidades (abundância, riqueza e Índice de Diversidade de Shanon) obtidos para os macroinvertebrados bentônicos considerando pontos em áreas controle (c) e áreas impactadas (i) ao longo do rio Formoso.

\begin{tabular}{|c|c|c|c|c|c|c|}
\hline Estaçōes & Pontos & $\begin{array}{l}\text { Profundidade } \\
\text { máxima } \\
\text { médialestação } \\
\text { (m) }\end{array}$ & $\begin{array}{l}\text { Profundidade máxima } \\
\text { média/ponto } \\
\text { (m) }\end{array}$ & $\begin{array}{l}\text { Riqueza taxonômica } \\
\left(n^{0} \text { taxa) }\right.\end{array}$ & $\begin{array}{l}\text { Abundância } \\
\left(\mathrm{n}^{0} \text {-ind. } / \mathrm{m}^{2}\right)\end{array}$ & $\begin{array}{l}\text { İndice de Diversidade } \\
\text { de Shanon-Wiener } \\
\text { (Bits) }\end{array}$ \\
\hline \multirow[t]{2}{*}{$A$} & Ac - Barra do Sucuri & \multirow{2}{*}{1,2} & 0,9 & 13 & 947,77 & 3,05 \\
\hline & Ai - Barra do Sucuri & & 0,7 & 11 & 818,30 & 2,85 \\
\hline \multirow[t]{2}{*}{$\bar{B}$} & BC - Praia da Figueira & \multirow[t]{2}{*}{$\overline{1,4}$} & $\overline{1,6}$ & 8 & 780,38 & 2,29 \\
\hline & Bi - Praia da Figueira & & 1,3 & 8 & 613,40 & 2,29 \\
\hline \multirow[t]{2}{*}{ c } & Cc - Bonito Aventura & \multirow[t]{2}{*}{2,5} & 2,5 & 13 & 454,59 & 3,22 \\
\hline & Ci - Bonito Aventura & & 2,3 & 10 & 234,90 & 2,92 \\
\hline \multirow[t]{2}{*}{ D } & Dc - Balneário Municipal & \multirow[t]{2}{*}{2,2} & 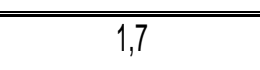 & 11 & 545,54 & $\overline{1,79}$ \\
\hline & Di - Banneário Municipal & & 1,3 & 4 & 121,40 & 1,65 \\
\hline \multirow[t]{2}{*}{$\mathrm{E}$} & Ec-Hotel Cabanas & \multirow[t]{2}{*}{2,5} & $\overline{1,7}$ & 20 & 613,55 & 3,70 \\
\hline & Ei-Hotel Cabanas & & 1,5 & 14 & 348,40 & 3,21 \\
\hline \multirow[t]{2}{*}{$\bar{F}$} & Fc - Balneário do Gordo & \multirow[t]{2}{*}{3,6} & $\overline{11,8}$ & 20 & $\overline{1393,85}$ & 3,30 \\
\hline & Fi - Baneário do Gordo & & 1,1 & 7 & 1803,01 & 1,62 \\
\hline \multirow[t]{2}{*}{ G } & Gc-birapê & \multirow[t]{2}{*}{1,9} & $\overline{1,20}$ & 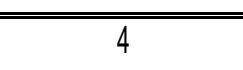 & 242,40 & $\overline{1,91}$ \\
\hline & Gi- Ibirapê & & 0,90 & 4 & 234,80 & 1,51 \\
\hline \multirow[t]{2}{*}{ H } & Hc - Balneário do Sol & \multirow[t]{2}{*}{2,0} & 1,10 & 8 & 1363,70 & 1,11 \\
\hline & Hi - Banneário do Sol & & 1,0 & 0 & 0 & 0 \\
\hline \multirow[t]{2}{*}{ 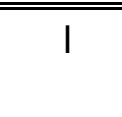 } & Ic - Hotel St ${ }^{a}$ Esmeralda & \multirow[t]{2}{*}{3,5} & 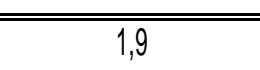 & $\overline{6}$ & 2189,45 & $\overline{1,14}$ \\
\hline & li - Hotel Stª Esmeralda & & 1,8 & 4 & 469,68 & 1,27 \\
\hline \multirow{2}{*}{$J$} & Jc - Faz. Iha Bonita & \multirow[t]{2}{*}{$\overline{4,5}$} & $\overline{4,5}$ & $\overline{6}$ & 204,52 & $\overline{1,99}$ \\
\hline & Ji - Faz. Iha Bonita & & 4,1 & 4 & 386,35 & 1,31 \\
\hline
\end{tabular}


Anexo 8. Continuação...

\begin{tabular}{|c|c|c|c|c|c|c|}
\hline Estaçôes & Pontos & $\begin{array}{l}\text { Protundidade } \\
\text { máxima } \\
\text { médialestacaão } \\
\text { (m) }\end{array}$ & $\begin{array}{l}\text { Profundidade máxima } \\
\text { média/ponto } \\
\text { (m) }\end{array}$ & $\begin{array}{l}\text { Riqueza taxonômica } \\
\qquad\left(n^{0} \text { taxa) }\right.\end{array}$ & $\begin{array}{l}\text { Abundância } \\
\text { (ñind/m2) }\end{array}$ & $\begin{array}{l}\text { Indice de Diversidade } \\
\text { de Shanon-Wiener } \\
\text { (Bits) }\end{array}$ \\
\hline \multirow[t]{2}{*}{ L } & Lc - Estância do Araçá & \multirow[t]{2}{*}{4,0} & 2,0 & 17 & 2810,51 & 2,35 \\
\hline & Li - Estância do Araçá & & 1,4 & 11 & 431,78 & 2,58 \\
\hline \multirow[t]{2}{*}{$\bar{M}$} & Mc - Hotel Faz. & \multirow[t]{2}{*}{4,0} & $\overline{20,2}$ & $\overline{2}$ & 83,40 & $0,0,44$ \\
\hline & Mi - Hotel Faz. & & 1,6 & 1 & 30,30 & 0 \\
\hline \multirow[t]{2}{*}{ N } & Nc - llha do Padre & \multirow[t]{2}{*}{4,0} & 2,80 & 11 & 2212,09 & 2,73 \\
\hline & $\mathrm{Ni}$ - llha do Padre & & 2,60 & 9 & 1363,58 & 2,29 \\
\hline \multirow[t]{2}{*}{0} & Oc-Camping Poliana & \multirow[t]{2}{*}{3,5} & $\overline{11,6}$ & 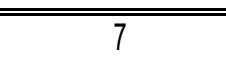 & 90,87 & 2,52 \\
\hline & Oi-Camping Poliana & & 1,1 & 2 & 37,87 & 0,72 \\
\hline \multirow[t]{2}{*}{$P$} & Pc-Hotel Formoso & \multirow[t]{2}{*}{3,5} & 1,8 & 9 & 659,01 & 1,91 \\
\hline & Pi - Hotel Formoso & & 1,8 & 6 & 1128,87 & 0,90 \\
\hline
\end{tabular}


Anexo 9. Abundância dos diferentes táxons de macroinvertebrados bentônicos (nnind./m2) coletados nos pontos controle (c) e de impacto (i) ao longo do rio Formoso.

\begin{tabular}{|c|c|c|c|c|c|c|c|c|c|c|c|c|c|c|c|c|c|c|c|c|c|c|c|c|c|c|c|c|c|}
\hline \multirow{3}{*}{ TAXON } & \multicolumn{29}{|c|}{ ABUNDÂACIA/PONTO (ind.m²) } \\
\hline & \multicolumn{2}{|c|}{ A } & \multicolumn{2}{|c|}{ B } & \multicolumn{2}{|c|}{ C } & \multicolumn{2}{|c|}{ D } & \multicolumn{2}{|c|}{$\mathrm{E}$} & \multicolumn{2}{|c|}{$\mathrm{F}$} & \multicolumn{2}{|c|}{ G } & \multicolumn{2}{|c|}{$\mathrm{H}$} & \multicolumn{2}{|c|}{ I } & \multicolumn{2}{|c|}{$\mathrm{J}$} & \multicolumn{2}{|c|}{$\mathrm{L}$} & \multicolumn{2}{|c|}{ M } & \multicolumn{2}{|c|}{$\mathrm{N}$} & 0 & \multicolumn{2}{|c|}{$\mathrm{P}$} \\
\hline & $C$ & 1 & $\mathrm{C}$ & 1 & $\mathrm{C}$ & $\mathrm{I}$ & $\mathrm{C}$ & 1 & $\mathrm{C}$ & 1 & $\mathrm{C}$ & 1 & $\mathrm{C}$ & 1 & $\mathrm{C}$ & 1 & $\mathrm{C}$ & 1 & $\mathrm{C}$ & 1 & $\mathrm{C}$ & 1 & $\mathrm{C}$ & 1 & $\mathrm{C}$ & 1 & C 1 & $\mathrm{C}$ & $\mathrm{I}$ \\
\hline \multicolumn{30}{|l|}{ INSECTA } \\
\hline Colembolla & & & & & & & & & & & 7,6 & & & & & & & & & & & & & & & & & & \\
\hline Coleoptera & & & & & & & & & & & & & & & & & & & & & & & & & & & & & \\
\hline Elmidae & 30,3 & 30,3 & & 22,7 & & & 7,6 & & & & 15,2 & 7,6 & & & 7,6 & & & & 15,2 & & 181,8 & & & & 7,6 & & & 7,6 & \\
\hline Dytiscidae & & & & & & & & & & & 45,5 & & & & & & & & & & & & & & & & & & \\
\hline Diptera & & & & & & & & & & & & & & & & & & & & & & & & & & & & & \\
\hline Ceratopogonidae & & & 15,15 & & & & & & & 7,57 & 60,6 & 83,3 & & & 30,3 & & & & & & 30,3 & 53,03 & & & 60,6 & & & 7,57 & \\
\hline Chironomidae & 265,2 & 303,0 & 166,7 & 287,9 & 113,6 & 53,0 & 22,8 & 60,7 & 106,1 & 98,5 & 522,7 & 651,5 & 60,6 & 83,3 & 272,7 & & 1681,9 & 15,2 & 98,5 & 204,5 & 1659,1 & 204,5 & 75,8 & 30,3 & 606,1 & 90,9 & 30,3 & 363,6 & 98,5 \\
\hline Simulidae & & & & & & & & & 15,2 & & & & & & & & & & & & & & & & & & & & \\
\hline Tipulidae & 15,2 & & & & & & & & & & & & & & & & & & & & & & & & & & & & \\
\hline Ephemeroptera & & & & & & & & & & & & & & & & & & & & & & & & & & & & & \\
\hline Baetidae & 15,2 & 7,6 & & & 83,3 & 22,7 & & & 121,2 & 7,6 & & & & & & & & & & & 7,6 & & & & & 30,3 & & & \\
\hline Caenidae & & & & & & & 7,6 & & & & 22,7 & & & & & & & & & & 60,6 & & & & & & 7,6 & 45,5 & \\
\hline Ephemeridae & & & 68,2 & & & & & & & & & 53,0 & & & & & & & & & 15,2 & & & & 424,2 & & & & \\
\hline Heptogeniidae & & & & & & & & & & & & & & & & & & & & & 60,6 & & & & & & & & \\
\hline Leptoplhebidae & 37,9 & 45,5 & & 22,7 & & & & & & & 15,2 & 15,2 & & & 7,6 & & & & & & 7,6 & & & & & & & & \\
\hline Polymitarcydae & & & & & & & 7,6 & & & & & & 90,9 & & & & 68,2 & & & & & & & & & 212,1 & & & \\
\hline Siphonuridae & & & & & & & & & & & 7,6 & & & & & & & & & & & & & & & & & & \\
\hline Tricorythidae & & & & & & 7,6 & & & 15,2 & & 53,0 & & & & & & & & & & & 15,2 & & & & & & 15,2 & \\
\hline Lepdoptera & & & & & & & & & & & & & & & & & & & & & & & & & & & & & \\
\hline Pyralidae & & & & & 30,3 & 60,6 & & & 15,15 & 60,6 & & & & & & & & & & & & & & & & & & & \\
\hline Odonata & & & & & & & & & & & & & & & & & & & & & & & & & & & & & \\
\hline Coenagrionidae & & & & & 7,6 & & & & 15,15 & 7,6 & 90,9 & & & & & & & & & & 60,6 & & & & & & & & \\
\hline Gomphidae & 60,6 & 45,5 & 30,3 & 37,9 & 37,9 & 30,3 & & & 30,3 & 37,9 & 7,6 & 53,0 & & 22,7 & 15,2 & & 45,5 & & 53,0 & 7,6 & 75,8 & 15,2 & & & 60,6 & 60,6 & 7,6 & 7,6 & 7,6 \\
\hline Libellulidae & & & & & 15,2 & 15,2 & & 15,2 & 7,6 & 22,7 & 30,3 & & 30,3 & & & & & & & & & 7,6 & & & & & & & 7,6 \\
\hline Tricoptera & & & & & & & & & & & & & & & & & & & & & & & & & & & & & \\
\hline Calamoceratidae & & & & & 22,7 & & & & 7,6 & & & & & & & & & & & & & & & & & & & & \\
\hline Cestoceridae & & & & & & & & & 7,6 & & & & & & & & & & & & & & & & & & & & \\
\hline Helicopshydae & 7,6 & & 166,7 & & & & & & & & & & & & & & & & & & & 7,6 & & & & & & & \\
\hline
\end{tabular}


Anexo 9. Continuação...

\begin{tabular}{|c|c|c|c|c|c|c|c|c|c|c|c|c|c|c|c|c|c|c|c|c|c|c|c|c|c|c|c|c|c|}
\hline \multirow{3}{*}{ TAXON } & \multicolumn{29}{|c|}{ ABUNDÂNCIA/PONTO (ind.m²) } \\
\hline & \multicolumn{2}{|c|}{$\mathrm{A}$} & \multicolumn{2}{|c|}{ B } & \multicolumn{2}{|c|}{ C } & \multicolumn{2}{|c|}{ D } & \multicolumn{2}{|c|}{$\mathrm{E}$} & \multicolumn{2}{|c|}{$\mathrm{F}$} & \multicolumn{2}{|c|}{ G } & \multicolumn{2}{|c|}{$\mathrm{H}$} & \multicolumn{2}{|c|}{ I } & \multicolumn{2}{|c|}{$\mathrm{J}$} & \multicolumn{2}{|c|}{$\mathrm{L}$} & M & \multicolumn{2}{|c|}{$\mathbf{N}$} & \multicolumn{2}{|c|}{0} & \multicolumn{2}{|c|}{$\mathrm{P}$} \\
\hline & $C$ & 1 & C & I & C & I & C & I & C & I & C & I & C & I & C & I & C & I & $C$ & 1 & C & I & C I & C & I & C & 1 & C & I \\
\hline Hydropilidae & & & & & 15,2 & & & & 15,2 & & & & & & & & & & & & & & & & & & & & \\
\hline Leptoceridae & & & & & 15,2 & 7,6 & & & 15,2 & 15,2 & 7,6 & & & & & & & 60,6 & 7,6 & & & 15,2 & & 30,3 & & 7,6 & & 7,6 & \\
\hline Polycentropodidae & & & & & & & 7,6 & & 75,8 & 30,3 & 68,2 & & & & & & & & & & 22,7 & 30,3 & & 60,6 & & & & & \\
\hline Phylopotamidae & 68,2 & 53 & & & & & 15,2 & & 7,6 & & & & & & 7,6 & & 7,6 & & & & & & & & 30,3 & & & & \\
\hline GASTROPODA & 90,9 & 121,2 & 318,2 & 37,9 & 60,6 & 7,6 & 7,6 & 7,6 & 45,5 & 7,6 & 83,3 & & & & 1053,0 & & 333,3 & 333,3 & & 15,2 & 197,0 & 30,3 & 7,6 & 212,1 & 666,7 & 7,6 & 30,3 & 181,8 & 60,6 \\
\hline BIVALVIA & 68,8 & 60,6 & & 60,6 & & & 30,3 & & 37,9 & 7,6 & 60,6 & & & & & & & & 7,6 & & 151,5 & & & 181,8 & 212,1 & 22,7 & 7,6 & & \\
\hline HIRUDINEA & 60,6 & 75,8 & & 15,2 & 7,6 & & 53,0 & & 7,6 & & 106,1 & & & & 7,6 & & & & & & & & & & 30,3 & & & & \\
\hline OLIGOCHAETA & 250,0 & 68,2 & 22,7 & 151,5 & 15,2 & 22,7 & 386,3 & 37,9 & 22,7 & 7,6 & 151,5 & 939,4 & 60,6 & 121,2 & & & 53,0 & 60,6 & & 159,1 & 219,7 & 45,5 & & 606,1 & 30,3 & 7,6 & & 37,9 & 878,8 \\
\hline TURBELLARIA & 7,6 & 7,6 & 7,6 & & & & & & & & 22,7 & & & & & & & & & & 15,2 & & & & & & & & \\
\hline MALACOSTRACA & & & & & & & & & & & & & & & & & & & & & & & & & & & & & \\
\hline Decapoda & & & & & & & 7,6 & & 7,57 & 7,57 & 15,15 & & & & & & & & & & 22,72 & & & & & & & & \\
\hline OSTRACODA & & & & & 30,3 & 7,6 & & & 37,9 & 30,3 & & & & 7,6 & & & & & 22,7 & & 22,7 & 7,6 & & 30,3 & & & & & 75,8 \\
\hline
\end{tabular}


Anexo 10. Grau de impacto à integridade dos habitats naturais do rio Formoso avaliado nas estações de amostragem

\begin{tabular}{|c|c|c|c|c|c|c|c|}
\hline Estações & Identificação & $\begin{array}{c}\text { Diversidade e } \\
\text { estabilidade de } \\
\text { substratos de fundo }\end{array}$ & $\begin{array}{l}\text { Estabilidade das } \\
\text { tufas calcárias }\end{array}$ & $\begin{array}{c}\text { Estabilidade das } \\
\text { barrancas }\end{array}$ & $\begin{array}{c}\text { Acessos } \\
\text { secundários ao rio }\end{array}$ & $\begin{array}{l}\text { Presença de } \\
\text { resíduos } \\
\text { sólidos nas }\end{array}$ & Total \\
\hline A & Barra do Sucuri & 76 & * & 31 & 4 & 0 & 111 \\
\hline $\bar{B}$ & Praia da Figueira & 36 & * & 8 & 2 & 0 & 46 \\
\hline $\bar{c}$ & Bonito Aventura & 35 & 28 & $\overline{18}$ & 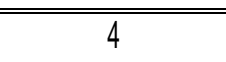 & 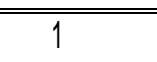 & 86 \\
\hline$\overline{D D}$ & Balneário Municipal & 137 & 20 & $\overline{52}$ & $\overline{5}$ & $\bar{~} 1$ & 215 \\
\hline $\bar{E}$ & Hotel Cabanas & $\overline{34}$ & $\overline{53}$ & $\overline{3}$ & $\overline{3}$ & $\overline{11}$ & 94 \\
\hline $\bar{F}$ & Baneário do Gordo & $\overline{73}$ & 13 & 70 & $\overline{88}$ & $\overline{11}$ & 2165 \\
\hline $\bar{G}$ & birapế & 13 & 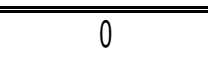 & 0 & 0 & 0 & 13 \\
\hline$\overline{\mathrm{H}}$ & Balneário do Sol & $\overline{109}$ & $\overline{10}$ & 59 & $\overline{77}$ & $\overline{3}$ & 188 \\
\hline $\bar{I}$ & Hotel St Esmeralda & 14 & $\overline{10}$ & 142 & $\overline{10}$ & $\overline{11}$ & 177 \\
\hline $\bar{J}$ & Faz. Itha Bonita & $\overline{16}$ & 60 & 7 & 2 & 0 & 31 \\
\hline 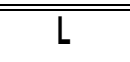 & Estância do Araçáa & 14 & 50 & 68 & 7 & 1 & 92 \\
\hline$\overline{\bar{M}}$ & H. Faz. Cachoeira & $\overline{13}$ & $\overline{50}$ & 35 & 3 & 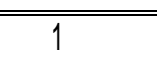 & 62 \\
\hline$\overline{\mathrm{N}}$ & |llha do Padre & 24 & 22 & 156 & 14 & 10 & 2226 \\
\hline 0 & Camping Poliana & 19 & 3 & 92 & 8 & 3 & 125 \\
\hline$P$ & Hotel Formoso & 7 & * & 16 & 2 & 0 & 25 \\
\hline
\end{tabular}

* não há ocorrência de tufas calcárias na estação de amostragem 